UNIVERSIDADE DE SÃO PAULO

ESCOLA DE COMUNICAÇÃO E ARTES

Tamya de Oliveira Ramos Moreira

Escola Nova e Educação Musical: um estudo através de imprensa pedagógica no entre-guerras

São Paulo

2019 


\title{
Escola Nova e Educação Musical: um estudo através de imprensa pedagógica no entre-guerras
}

\author{
Versão corrigida
}

Tese apresentada à Escola de Comunicações e Artes da Universidade de São Paulo para obtenção do título de Doutora em Artes pelo Programa de Pós-Graduação em Música.

Área de Concentração: Processos de Criação Musical

Orientadora: Prof ${ }^{\mathrm{a}}$. Dr ${ }^{\mathrm{a}}$. Maria Teresa Alencar de Brito

São Paulo

2019 
Autorizo a reprodução e divulgação total ou parcial deste trabalho, por qualquer meio convencional ou eletrônico, para fins de estudo e pesquisa, desde que citada a fonte.

Catalogação na Publicação

Serviço de Biblioteca e Documentação

Escola de Comunicações e Artes da Universidade de São Paulo

Dados inseridos pelo(a) autor(a)

Moreira, Tamya de Oliveira Ramos

Escola Nova e Educação Musical: um estudo através de

imprensa pedagógica no entre-guerras / Tamya de Oliveira

Ramos Moreira ; orientadora, Maria Teresa Alencar de Brito.

-- São Paulo, 2019.

247 p.: il.

Tese (Doutorado) - Programa de Pós-Graduação em Música -

Escola de Comunicações e Artes / Universidade de São Paulo. Bibliografia

Versão corrigida

1. Práticas Criativas 2. Satis Coleman 3. Escola Nova 4.

Progressive Education 5. La Nouvelle Éducation I. Alencar de Brito, Maria Teresa II. Título.

CDD 21.ed. - 780

Elaborado por Sarah Lorenzon Ferreira - CRB-8/6888 
Nome: MOREIRA, Tamya de Oliveira Ramos.

Título: Escola Nova e Educação Musical: um estudo através de imprensa pedagógica no entre-guerras.

Tese apresentada à Escola de Comunicações e Artes da Universidade de São Paulo para obtenção do título de Doutora em Artes pelo Programa de Pós-Graduação em Música.

Aprovada em 31/07/2019

Banca Examinadora

Profa. Dra. Maria Teresa Alencar de Brito

Instituição: Universidade de São Paulo

Julgamento:

Prof. Dr.: Mário Rodrigues Videira Júnior

Instituição: Universidade de São Paulo

Julgamento:

Profa. Dra.: Marisa Trench de Oliveira Fonterrada

Instituição: Universidade Estadual Paulista - UNESP

Julgamento:

Profa. Dra.: Viviane Beineke

Instituição: Universidade do Estado de Santa Catarina - UDESC

Julgamento:

Profa. Dra.: Sandra Mara da Cunha

Instituição: Universidade do Estado de Santa Catarina - UDESC

Julgamento: 


\section{Agradecimentos}

À Fundação de Amparo à Pesquisa do Estado de São Paulo (FAPESP) e à Coordenação de Aperfeiçoamento de Pessoal de Nível Superior (CAPES). A presente tese refere-se ao processo $n^{\circ}$ 2015/01978-0 (FAPESP/CAPES). As opiniões, hipóteses e conclusões ou recomendações expressas nesse material são de responsabilidade da autora e não necessariamente refletem a visão da FAPESP.

A todos os funcionários de todas as instituições pelas quais passei nestes últimos anos, especialmente aos bibliotecários. Este e outros tantos trabalhos não existiriam sem tais profissionais.

À Teca Alencar de Brito, por apostar nas minhas primeiras suposições, acreditar no meu projeto de pesquisa e na minha capacidade de realizá-lo. Mais de oito anos depois da primeira aula, por continuar sendo grande fonte de inspiração, alimentando todos a sua volta com sua paixão pela música e pela infância.

À Antoine Savoye, d'avoir accepté la supervision et de m'avoir aidée pendant mon stage en France. Ses écrits et ses indications sur la littérature et la méthodologie ont été fondamentaux pour la réalisation de cette thèse.

Às professoras e professores que contribuíram para o desenvolvimento do trabalho oferecendo disciplinas. Especialmente à Maria Ângela Salvadori, por abrir a porta para a área da História de maneira tão generosa e competente.

Às professoras e professores que se dispuseram a ler e apresentar contribuições nas bancas de qualificação e defesa.

À Carolina Mota, por manter meus tendões aptos à digitação.

À minha família, por compreender minha ausência e festejar minha presença. Especialmente aos meus sobrinhos, por cantarem comigo, com a esperança de que a escola lhes seja fecunda como foi para mim. E à Vó Dalila, que, em vida, tanto me ensinou sobre obstinação e paciência enquanto tocava seu teclado.

Às minhas amigas e amigos, de longe e de perto, de hoje e de outros tempos. Que sorte tenho de dividir a vida com essas pessoas! Em especial ao Diego Munhoz, pela câmera (com a qual as imagens da tese foram feitas), o piano, o sofá, a conta bancária, a caixa de correio, os banoffees; por tanto me ensinar sobre coragem e sinceridade sem nem mesmo se dar conta. Eu poderia virar todas as páginas da música ocidental e ainda estaria em dívida.

Ao Ricardo Lira. Companheirismo, amor e saudade são palavras insuficientes. "Mão no leme, pé no carnaval...". 
Daqui por algumas semanas este menino fará as suas primeiras tentativas para pôr-se de pé e caminhar, irá de mãos ao chão vezes sem conta e ficará a olhar em frente, a cabeça dificilmente levantada, enquanto ouve a voz da mãe que lhe diz, Vem cá, vem cá, meu menino, e não muito tempo depois sentirá a primeira necessidade de falar, quando alguns sons novos começarem a formar-se na sua garganta, e ao princípio não saberá que fazer com eles, confundi-los-á com os outros que já conhecia e vinha praticando, os do grito e os do choro, porém não tardará a perceber que deve articulá-los de um modo muito diferente, mais compenetrado, imitando e ajudando-se com os movimentos dos lábios do pai e da mãe, até que consiga pronunciar a primeira palavra, qual ela tenha sido não sabemos, talvez papa, talvez papá, talvez mamã, o que sim sabemos é que a partir de agora nunca mais o menino Jesus terá de fazer aquele gesto do indicador da mão direita na palma da mão esquerda se a mãe e as vizinhas tornarem a perguntar-lhe, Onde é que a galinha põe o ovo, é uma indignidade a que se sujeita o ser humano, tratá-lo como um cãozito ensinado a reagir a um estímulo sonoro, voz, assobio ou estalo de chicote. Agora Jesus está capacitado para responder que a galinha pode ir pôr o ovo aonde quiser, desde que não o faça na palma da sua mão

(SARAMAGO, 1991, p. 126) 
MOREIRA, Tamya de O. R. Escola Nova e Educação Musical: um estudo através de imprensa pedagógica do entre-guerras. 2019. Tese (Doutorado) - Escola de Comunicações e Artes, Universidade de São Paulo, 2019.

\section{Resumo}

A presente pesquisa parte da constatação da proeminência da valorização das práticas criativas nos discursos recentes da área da Educação Musical, valorização esta que, não poucas vezes, é acompanhada de considerações sobre sua ainda escassa efetivação no ensino, sobretudo em se tratando da escola de educação básica brasileira. Se, por um lado, a abertura para os práticas criativas infantis em nossa área é correntemente relacionada a propostas da segunda metade do século XX, especialmente em conexões com as inovações técnicas e estéticas oriundas do campo composicional, por outro, a valorização de atividades criativas em contexto pedagógico mais amplo está vinculada aos movimentos de renovação escolar do início do referido século. $O$ trabalho que aqui se apresenta foi empreendido com o objetivo de investigar este aparente descompasso. A partir da análise de imprensa pedagógica do período entre-guerras - mais especificamente as revistas Progressive Education (Estados Unidos), La Nouvelle Éducation (França) e Revista Brasileira de Estudos Pedagógicos, publicadas nas décadas de 1920, 1930 e 1940 - e de bibliografia secundária, buscamos traçar um retrato da Educação Musical quando esta esteve inserida em movimentos renovadores. $\mathrm{O}$ exame deste material nos permite confirmar a tese de que neste cenário já existiam aberturas para o incentivo à criação musical infantil e que tal atividade era fundamental, bem como a participação das crianças de uma maneira mais ampla. Os exemplos apresentados são indícios de que a Educação Musical esteve incorporada de maneira coerente a tais projetos pedagógicos. A presente tese também dá a ver a circulação de experimentos em educação musical nos três contextos estudados, especialmente a influência do trabalho da educadora estadunidense Satis Coleman, apropriado de maneiras particulares na Europa e no Brasil. Por fim, este estudo trata ainda da necessidade de interpretar o ideário escolanovista em sua vinculação estreita com o aspecto social da instituição escolar. Tal necessidade provém das associações corriqueiras estabelecidas entre escolanovismo e qualquer proposta de educação musical apoiada na psicologia experimental do início do século XX ou que apresente qualquer inovação nos âmbitos da didática e dos conteúdos. Apontamos os limites de associações desta natureza na medida em que não levam em consideração um aspecto fulcral dos movimentos renovadores aqui estudados: o fato de terem como lócus específico a escola de educação básica no momento histórico em que esta se estabelece como lugar social da infância e adaptado a esta fase da vida.

Palavras-chave: Educação Musical, Criação Musical, Práticas Criativas, Satis Coleman, Escola Nova, Progressive Education, La Nouvelle Éducation, Imprensa Pedagógica. 
MOREIRA, Tamya de O. R. Escola Nova and Music Education: a study through pedagogical press in the interwar period. 2019. Tese (Doutorado) - Escola de Comunicações e Artes, Universidade de São Paulo, 2019.

\begin{abstract}
This research stems from the observation that creative practices are prominent as valued pedagogical tool in the recent discourses of the Music Education area. This valorization is frequently accompanied by considerations of its still scarce effectiveness in teaching, especially in the case of the Brazilian school. If, on the one hand, the opening to children's creative activities in our area is currently related to proposals of the second half of the twentieth century, especially in connection with technical and aesthetic innovations from the compositional field, on the other hand, the valuation of creative activities in a broader pedagogical context is linked to the school renovation movements dated at the beginning of this century. The work presented here was undertaken with the objective of investigating this apparent mismatch. From the pedagogical press analysis of the interwar period - specifically the journals Progressive Education (United States), La Nouvelle Éducation (France) and Revista Brasileira de Estudos Pedagógicos (Brazil), published in the 1920s, 1930s and 1940s - and secondary sources, we sought to draw a picture of Music Education as it was inserted in renovating movements. The examination of this material allows us to confirm the thesis that in this scenario there were already cases of encouragement of children's musical creation and that such activity was fundamental, as well as the children's participation in a broader way. The examples presented are indications that Music Education was incorporated in a coherent way to such pedagogical projects. The present thesis also shows the circulation of experiments in music education in the three studied contexts, especially the influence of the work developed by the American educator Satis Coleman and appropriated in particular ways in Europe and Brazil. Finally, this study also stresses the need to interpret the Escolanovista ideas in its close connection with the social aspect of the school institution. This need arises from the common associations established between Escolanovismo and any proposal of music education based on the experimental psychology of the early twentieth century or any proposal that presents any innovation in the fields of didactics and content. We point out the limits of associations of this nature insofar as they do not take into account a central aspect of the renovating movements studied here: the fact that they have as their specific locus the school precisely in the historical moment in which this institution establishes itself as a social place of childhood and adapted to this phase of life.
\end{abstract}

Keywords: Music Education, Creative Practices, Satis Coleman, Escola Nova, Progressive Education, La Nouvelle Éducation, Pedagogical Press. 
CAPÍTULO 1 - CRIAÇÃO MUSICAL E ESCOLA NOVA: TRAC̣ANDO A INVESTIGAC̣ÃO 21

$\begin{array}{ll}\text { 1.1 O OBJETO DE ESTUDO E AS PERGUNTAS } & 21\end{array}$

1.2 NOVIDADE E PROGRESSO: POLIFONIA INTERNACIONAL E A NEGAÇÃo COMO CONSENSO 38

1.3 DEFININDO O CAMINHO: PERIODIZAÇÃO, SELEÇÃO DE FONTES, PRESSUPOSTOS TEÓRICOS E

METODOLÓGICOS

CAPÍTULO 2 - EDUCAC̣ÃO MUSICAL E RENOVAC̣ÃO ESCOLAR NOS ESTADOS UNIDOS 52

2.1 Progressive Education 52

2.2 A EDUCAÇÃO MUSICAL NA REVISTA PROGRESSIVE EDUCATION 57

2. 3 Satis Coleman e a Creative Music 86

CAPÍTULO 3 - EDUCAC̣ÃO MUSICAL E RENOVAC̣ÃO ESCOLAR NA FRANÇA 146

3.1 NOVIDADES CONTINENTAIS E LOCAIS

3.2 O CONGRESSO INTERNACIONAL DE CALAIS (1921)

3.3 La NOUVELLE ÉDUCATION

CAPÍTULO 4 - EDUCAC̣ÃO MUSICAL E RENOVAC̣ÃO ESCOLAR NO BRASIL 198

4.1 O ESColanovismo E a ReVista Brasileira de ESTUdos Pedagógicos 198

4.2 MÚSICA CRIADORA: ColEMAN POR CALDEIRA FILHO 210

4.3 INICIAÇÃO MUSICAL: UM ESCOLANOVISMO FORA DA ESCOLA?

NOVIDADES QUASE CENTENÁRIAS: CONSIDERAÇÕES E APONTAMENTOS 228

REFERÊNCIAS 233

REVISTAS CONSULTADAS 233

DEMAIS REFERÊNCIAS 233 


\section{Introdução}

$\mathrm{Na}$ passagem ficcional que apresentamos aqui por epígrafe, o narrador nos conta como uma criança, ao tomar a palavra, se livra da situação onde era levada a interagir com os adultos a sua volta através de um movimento padronizado, ainda que não desprovido de alguma graciosidade. A criança - o menino Jesus de Saramago -, passa por uma transformação da qualidade de sua atividade perante as pessoas com quem interage. Nutrindo-se do que observa e experimentando com sua própria voz, ela alcança uma condição na qual, enfim, não necessariamente responderá aos estímulos do ambiente de maneira irrefletida.

Desde o início de nosso caminho em pesquisa e em prática pedagógica - e a presente tese é mais um passo deste percurso - parece-nos evidente que, tanto nas atividades de construção de conhecimento sobre educação, quanto nas ações educativas junto às crianças, não se pode ir muito longe sem que elas, de alguma maneira, sejam ouvidas. Em pesquisa de iniciação científica, isso se realizou através de entrevistas com crianças em sessões de escuta musical. A pesquisa ${ }^{1}$ desenvolvida entre os anos de 2010 e 2011 teve por título A escuta na infância: um estudo teóricoprático, e consistiu na análise de entrevistas feitas com crianças de sete a nove anos de idade após a escuta de obras de Arnold Schoenberg, Antonio Vivaldi, Jônatas Mazolli e Raul do Valle. Estas entrevistas nos mostraram as diferentes estratégias que as crianças elaboravam para organizar e comunicar sua experiência com as obras, suas condutas de escuta. Para tanto, valemo-nos de leituras de Pierre Schaeffer, François Delalande e Keith Swanwick.

Em pesquisa de mestrado ${ }^{2}$, interessamo-nos pelo Movimento Escola Moderna, fundado por Célestin Freinet. A investigação partia da constatação de que tal movimento desenvolveu-se e multiplicou-se pela publicação de textos de crianças. A Pedagogia Freinet, como ficou popularmente conhecida, constitui-se de uma grande variedade de pressupostos e ferramentas didáticas, tendo por ponto central a alfabetização através do texto livre. No movimento pedagógico em questão, as

\footnotetext{
${ }^{1}$ Desenvolvida sob orientação da Prof ${ }^{\natural}$. Dr ${ }^{\mathrm{a}}$. Denise Garcia, no Departamento de Música do Instituto de Artes da Universidade de Campinas. Processo Fapesp 2010/13115-2.

${ }^{2}$ A Música na Pedagogia Freinet: diálogos com a Educação Musical do século XX. Pesquisa desenvolvida entre 2012 e 2014 sob orientação da Prof ${ }^{a}$. Dr ${ }^{\mathrm{a}}$. Maria Teresa Alencar de Brito, no Programa de Pós-Graduação em Música da Escola de Comunicações e Artes da Universidade de São Paulo. Processo Fapesp 2012/09841-5.
} 
crianças entram no mundo das letras tomando a palavra, de maneira tateada, gradual e, sobretudo, significativa. Empreendemos, então, um estudo sobre se e como a educação musical, quando inserida neste movimento, esteve em coerência com o projeto pedagógico mais amplo. Um dos resultados de nossa pesquisa foi a constatação de que várias ações em nossa área estavam impregnadas dos pressupostos pedagógicos gerais. Isso se mostrou nas discussões entre educadores musicais na imprensa cooperativa e, especialmente, na valorização das composições e improvisações infantis registradas em discos, com destaque para a atividade na década de 1970.

Pareceu-nos, então, que o reconhecimento dos processos infantis de criação poderiam ser, em nossa área, um lugar de promoção da mudança na qualidade da experiência com a música e com o entorno. Partindo da constatação de que este reconhecimento já ocupa lugar considerável nos discursos sobre educação musical, mesmo em documentos oficiais, e, ao mesmo tempo, é acompanhado de constantes considerações acerca sua insuficiente realização, empreendemos a pesquisa que é apresentada nesta tese. Visto que, por um lado, a valorização dos processos criativos em educação musical é correntemente associada às aberturas estéticas do campo composicional do pós-guerra e que, por outro lado, as crianças já vinham ganhando lugar de participação e expressão na educação de uma maneira geral desde o início do século passado, decidimos buscar fontes que nos fizessem, senão superar, ao menos compreender melhor esse quadro de aparente descompasso. Nossa hipótese inicial consistia na possível existência de propostas de educação musical inseridas de maneira coerente nos movimentos de renovação escolar do entre-guerras - portanto, ainda na primeira metade do século $\mathrm{XX}$-, e que um dos traços dessa coerência seria o incentivo aos processos criativos. Pensando mais uma vez na cena de Saramago, ainda que não pudéssemos encontrar ecos nítidos das vozes das crianças, acreditávamos existir indícios de que, em educação musical, a elas já vinha sendo dada a abertura para se fazer muito mais do que levar o indicador direito à palma da mão esquerda.

A presente tese buscará expor os resultados dessa investigação sobre as propostas de educação musical nos movimentos de renovação escolar. Os pressupostos iniciais, as escolhas de periodização e fontes e as bases teóricas e metodológicas que nos guiaram na pesquisa serão apresentados em nosso primeiro capítulo. Na seção de abertura também será exposta a impossibilidade de definir 
precisamente o que foi a Escola Nova - ou Progressive Education e Éducation Nouvelle -, ao mesmo tempo em que apontará suas características centrais. Uma dessas características diz respeito à estrutura de nossa tese, a saber: a circulação internacional de ideias pedagógicas através de imprensa especializada. Os capítulos que se seguem tratarão dos cenários estadunidense, francês e brasileiro, através da análise de revistas produzidas nesses países.

O segundo capítulo apresentará um estudo sobre a educação musical em meio ao cenário da Progressive Education, associação de educadores estadunidenses. Ali constarão conteúdos identificados na revista homônima publicada pela associação e também uma exposição da proposta pedagógica de Satis Coleman. Essa educadora publicou obra numerosa e esteve à frente das aulas de creative music para crianças da Lincoln School, escola laboratório do Teachers College da Columbia University, assumindo também a formação de professores na mesma instituição. A observação atenta dessa proposta será válida ao leitor, pois constitui um importante ponto de convergência entre as inovações pedagógicas gerais e os caminhos da educação musical em tal contexto. Nos materiais estadunidenses analisados, ficará evidente que a criação musical era ponto de destaque nas práticas e discussões, ao lado de temas como o repertório e as novas tecnologias de gravação e difusão sonora.

O terceiro capítulo terá como objeto a renovação escolar na França através de suas representações na revista La Nouvelle Éducation. Serão expostos os conteúdos dessa revista quando tratou de nossa área, evidenciando a influência de referências de língua inglesa - como Satis Coleman e Margaret James - e da presença de práticas criativas em projetos de música vocal e instrumental. Os conteúdos corroboram aqueles do capítulo anterior, não apenas concernentes à importância das práticas criativas, mas também às discussões sobre repertório e os novos hábitos de escuta de música gravada. Terão espaço, ainda, considerações sobre as trocas entre educadores para além das revistas, em eventos como os congressos internacionais da Liga Internacional pela Educação Nova e as assembleias nacionais da associação $L a$ Nouvelle Éducation.

No quarto capítulo, nos dedicaremos ao contexto brasileiro. As particularidades de nosso país ficarão evidentes já de início, pois a revista da qual parte o trabalho deste capítulo tem conteúdo menos numeroso e periodização tardia, se comparada às demais. A Revista Brasileira de Estudos Pedagógicos, por ser publicação ligada ao Ministério da Educação, dá a ver, ainda, algo muito específico 
do escolanovismo brasileiro: sua condição institucional. O leitor encontrará um estudo deste material, que nos conduzirá às tentativas de divulgação da obra de Coleman por João Caldeira Filho. Trataremos, ainda, de refletir sobre os limites de se correlacionar os cursos de Iniciação Musical criados no Rio de Janeiro ao final da década de 1930 e o escolanovismo, enquanto se atribui ao Canto Orfeônico uma ligação com a Escola Tradicional.

Por fim, serão apresentadas considerações finais sobre os conteúdos da tese, bem como apontamentos sobre pontos que mereceriam desenvolvimentos posteriores mais pormenorizados. Será possível constatar, ainda, que muitos dos assuntos que guiam as discussões atuais sobre a nossa área já estavam postos no início do século passado. 


\section{Capítulo 1 - Criação musical e Escola Nova: traçando a investigação}

\section{$1.1 \mathrm{O}$ objeto de estudo e as perguntas}

A importância das práticas criativas no ensino de música parece bem estabelecida nos discursos correntes da área. Em âmbito nacional, isso pode ser observado em documentos oficiais, como na versão final da Base Nacional Comum Curricular - BNCC - homologada em 2018; bem como em direcionamentos curriculares mais antigos, como os Parâmetros Curriculares Nacionais - PCN (BRASIL, 1997) e o Referencial Curricular Nacional para a Educação Infantil RCNEI (BRASIL, 1998). Nestes documentos, as práticas de exploração sonora e criação musical são, de modo geral, tomadas como relevantes.

A versão final da Base Nacional Comum Curricular ${ }^{3}$ trata de nossa área em todas as três etapas da Educação Básica. Em cada etapa, contudo, as competências gerais a serem desenvolvidas são apresentadas de acordo com organização e nomenclatura próprias. A seção concernente à Educação Infantil está organizada em cinco "Campos de experiências", dentre os quais consta um de nome "Traços, sons, cores e formas", onde encontramos referências à Música. A seção destinada ao Ensino Fundamental organiza-se em "Áreas do conhecimento" subdividas em "Componentes curriculares". Aí encontramos a Música como parte do componente curricular "Arte", sendo este um subgrupo da área de conhecimento "Linguagens". O Ensino Médio também divide-se em "Áreas do conhecimento" com seus "Componentes curriculares", mas aqui a área onde identificamos conteúdos referentes à Música tem por nome "Linguagens e suas Tecnologias".

No capítulo dedicado à Educação Infantil, a expressão das crianças pequenas está ligada às linguagens artísticas e as práticas de criação aparecem, inicialmente, como fundamentais.

[...] elas [as crianças] se expressam por várias linguagens, criando suas próprias produções artísticas ou culturais, exercitando a autoria (coletiva e individual) com sons, traços, gestos, danças, mímicas, encenações, canções, desenhos, modelagens, manipulação de diversos materiais e de recursos tecnológicos. Essas experiências contribuem para que, desde muito pequenas, as crianças desenvolvam senso estético e crítico, o conhecimento de si mesmas, dos outros e da realidade que as cerca (BRASIL, 2018, p. 41)

\footnotetext{
${ }^{3}$ Disponível em http://basenacionalcomum.mec.gov.br/ Acesso em 29 mar. 2019
} 
A partir do trecho supracitado, retirado da apresentação do Campo de Experiência "Traços, sons, cores e formas", parece inegável que a criação é valorizada no documento desde os anos iniciais da escolarização. No entanto, através do exame do texto sobre os conhecimentos e competências mínimas de acordo com as três faixas etárias - zero a 1 ano e seis meses; 1 ano e 7 meses a 3 anos e 11 meses ; 4 a 5 anos e 11 meses; sendo as duas primeiras relacionadas à "Creche" e a última, à "Pré-escola" -, pode-se perceber que a produção musical das crianças pequenas ainda está sobremaneira associada ao acompanhamento de canções. Cunha (2018), ao analisar tal conteúdo do documento, afirma que os objetivos de aprendizagem e desenvolvimento assim estabelecidos acabam por invisibilizar as crianças, na medida em que não consideram suas capacidades autoral e investigativa. Apontamos, contudo, que, ainda que demasiadamente restrita, a ideia de criação está posta e mobiliza discussões sobre seus limites.

Em sua apresentação na seção dedicada ao Ensino Fundamental, a criação em Arte está ligada não apenas ao processo de ensino e aprendizagem, mas também justifica-se como via para o protagonismo dos estudantes, como exposto no trecho a seguir:

[...] as manifestações artísticas não podem ser reduzidas às produções legitimadas pelas instituições culturais e veiculadas pela mídia, tampouco a prática artística pode ser vista como mera aquisição de códigos e técnicas. A aprendizagem da Arte precisa alcançar a experiência e a vivência artísticas como prática social, permitindo que os alunos sejam protagonistas e criadores. [...] Os processos de criação precisam ser compreendidos como tão relevantes quanto os eventuais produtos. Além disso, o compartilhamento das ações artísticas produzidas pelos alunos, em diálogo com seus professores, pode acontecer não apenas em eventos específicos, mas ao longo do ano, sendo parte de um trabalho em processo (BRASIL, 2018, p.193)

O componente estrutura-se em seis dimensões do conhecimento, a saber: criação, crítica, estesia, expressão, fruição e reflexão; os quais devem ser articulados de maneira indissociável e simultânea nas abordagens educativas em Arte. A criação aparece logo como a primeira entre as dimensões e é descrita da seguinte maneira:

Criação: refere-se ao fazer artístico, quando os sujeitos criam, produzem e constroem. Trata-se de uma atitude intencional e 
investigativa que confere materialidade estética a sentimentos, ideias, desejos e representações em processos, acontecimentos e produções artísticas individuais ou coletivas. Essa dimensão trata do apreender o que está em jogo durante o fazer artístico, processo permeado por tomadas de decisão, entraves, desafios, conflitos, negociações e inquietações (BRASIL, 2018, p. 194)

Ao tratar de cada linguagem nas duas etapas do ensino fundamental, o documento apresenta seus conteúdos em eixos específicos. Na Música, um dos eixos intitula-se Processos de Criação, ao qual se somam Contextos e Práticas, Elementos da Linguagem, Materialidades e Notação e Registro Musical. A prática de criação aparece de maneira bastante variada, incluindo improvisações, composições, sonorizações de histórias, arranjos, jingles, trilhas sonoras, entre outros. Os materiais também devem ser variados, como percussão corporal, instrumentos convencionais e não-convencionais, além de recursos tecnológicos. Os processos devem se dar tanto em âmbito individual, quanto em projetos coletivos e colaborativos.

$\mathrm{Na}$ seção dedicada ao Ensino Médio, esta etapa da educação básica aparece como momento de aprofundamento dos Componentes do Ensino Fundamental, "com o objetivo de consolidar, aprofundar e ampliar a formação integral" (BRASIL, 2018, p.471, grifo no original), mas agora levando em conta as especificidades do mundo jovem. Quando trata da área de Linguagens e suas tecnologias, afirma-se que o foco

[...] está na ampliação da autonomia, do protagonismo e da autoria nas práticas de diferentes linguagens; na identificação e na crítica aos diferentes usos das linguagens, explicitando seu poder no estabelecimento de relações; na apreciação e na participação em diversas manifestações artísticas e culturais; e no uso criativo das diversas mídias (2018, p. 471, grifos nossos)

Prosseguindo pelos níveis de organização do documento, o componente Arte também traz em sua caracterização a importância dos processos criativos, como no trecho a seguir:

A proposta de progressão das aprendizagens no Ensino Médio prevê o aprofundamento na pesquisa e no desenvolvimento de processos de criação autorais nas linguagens das artes visuais, do audiovisual, da dança, do teatro, das artes circenses e da música. [...] Um ambiente propício para o engajamento dos estudantes em processos criativos deve permitir a incorporação de estudos, pesquisas e referências estéticas, poéticas, sociais, culturais e políticas para a criação de projetos artísticos individuais, coletivos e colaborativos, 
capazes de gerar processos de transformação, crescimento e reelaboração de poéticas individuais e coletivas (BRASIL, 2018, p. 482 , grifos nossos)

No último nível de organização, aquele referente às habilidades a serem desenvolvidas, mais uma vez está presente a atuação em processos de criação individuais, coletivos e colaborativos como meio de desenvolvimento e expressão dos estudantes. A criação como processo educativo na BNCC poderia, evidentemente, ser objeto de exame detalhado de acordo com suas características e seus possíveis limites. O que nos interessa neste momento é a constatação de que sua presença no documento é de incontestável relevância.

No texto dedicado à Música no Referencial Curricular Nacional para a Educação Infantil - RCNEI, lemos dentre os objetivos que as crianças de zero a três anos de idade devem desenvolver, entre outras capacidades, as de "brincar com a música, imitar, inventar e reproduzir criações musicais” (BRASIL, 1998, p. 55, grifo nosso); e às crianças de quatro a seis anos de idade devem ser garantidas as oportunidades de "explorar e identificar elementos da música", bem como "perceber e expressar sensações, sentimentos e pensamentos, por meio de improvisações, composições e interpretações musicais" (BRASIL, 1998, p. 55).

Em seus conteúdos - organizados em "O fazer musical" e "Apreciação musical", onde também constam questões referentes à reflexão - , encontramos definições dos processos criativos específicos da linguagem

O fazer musical é uma forma de comunicação e expressão que acontece por meio da improvisação, da composição e da interpretação. Improvisar é criar instantaneamente, orientando-se por alguns critérios pré-definidos, mas com grande margem a realizações aleatórias, não-determinadas. Compor é criar a partir de estruturas fixas e determinadas e interpretar é executar uma composição contando com a participação expressiva do intérprete (idem, p. 57)

As definições se justificam pela natureza do documento, que é destinado aos profissionais da educação infantil, não necessariamente formados para o ensino de música. O texto conta ainda com orientações didáticas que tratam especificamente de atividades de improvisação e composição, entre outras.

Nos Parâmetros Curriculares Nacionais - $\mathrm{PCN}$-, as práticas criativas musicais estão, ao lado da interpretação, contidas na seção "comunicação e expressão em 
música". Dentre o que se lista nesta seção, transcrevemos a seguir alguns direcionamentos para atividades de criação

Arranjos, improvisações e composições dos próprios alunos baseadas nos elementos da linguagem musical, em atividades que valorizem seus processos pessoais, conexões com a sua própria localidade e suas identidades culturais.

Experimentação e criação de técnicas relativas à interpretação, à improvisação e à composição.

Experimentação, seleção e utilização de instrumentos, materiais sonoros, equipamentos e tecnologias disponíveis em arranjos, composições e improvisações.

Seleção e tomadas de decisões, em produções individuais e/ou grupais, com relação às ideias musicais, letra, técnicas, sonoridades, texturas, dinâmica, forma, etc. (BRASIL, 1997, p. 78)

A criação aparece novamente na seção de avaliação e nas orientações didáticas. Nesta última, figura como via privilegiada para o processo de construção de conhecimento em Arte. De acordo com o documento, o processo de conhecimento se dá especialmente pela resolução de problemas e, especificamente em Arte, uma das classes de problemas identificadas diz respeito àqueles

[...] inerentes ao percurso criador do aluno, ligados à construção da forma artística, ou seja, à criação, envolvendo questões relativas às técnicas, aos materiais e aos modos pessoais de articular sua possibilidade expressiva às técnicas e aos materiais disponíveis, organizados numa forma que realize sua intenção criadora (BRASIL, 1997, p. 106)

Foge ao propósito do presente trabalho elaborar uma análise acerca da maneira como as práticas e os processos criativos aparecem e apareceram em documentos oficiais. Esta seria uma tarefa complexa e dependeria de um trabalho de pesquisa específico ${ }^{4}$. Aqui, sua menção aponta para o fato de que a presença das práticas criativas na educação musical em meio aos mais recentes documentos oficiais é notável. Partindo do pressuposto de que vivemos em uma sociedade escolarizada onde a garantia de oferta da instituição escolar é considerada dever do Estado, a despeito de críticas contundentes à tal instituição empreendidas principalmente na

\footnotetext{
${ }^{4}$ Em relação aos Parâmetros Curriculares Nacionais, por exemplo, é notável o trabalho desenvolvido por Penna (2001) pela sua abrangência de temas e diálogo com outras avaliações em Música e com as demais linguagens artísticas no documento. Considerações específicas sobre os limites do tratamento dado à Improvisação e à Composição nos PCN, bem como sua provável falta de aplicação, são elaborados por Fonterrada (1998).
} 
década de 1970 (ILLICH, 1973; BOURDIEU e PASSERON, 1975; ALTHUSSER, 1985) -, a redação destes documentos indica, ao menos no âmbito dos discursos, questões consideradas importantes para a área em determinado momento.

Em relação ao cenário acadêmico, um retrato nos é fornecido pelo estudo intitulado Ciranda de Sons: Práticas Criativas em Educação Musical, desenvolvido por Fonterrada (2015), com colaboração do GEPEM - Grupo de Pesquisa em Educação Musical - do Instituto de Artes da UNESP. Sobre a produção de pesquisas com temática ligada à relação entre criação e educação musical, é possível observar um pequeno crescimento do interesse pelo tema com base na quantidade de dissertações e teses defendidas entre 1992 e 2011 no Brasil. Ainda neste estudo, é possível encontrar dados sobre a veiculação de textos acerca do tema em anais de conferências da ANPPOM - Associação Nacional de Pesquisa e Pós-graduação em Música - e da ABEM - Associação Brasileira de Educação Musical, bem como em seis periódicos de música nacionais. De acordo com tal análise, o tema se torna expressivamente recorrente nessas publicações a partir da segunda metade da década de 2000.

Apesar da valorização das práticas criativas nos discursos sobre educação musical, ainda não parece possível afirmar que sua presença em sala de aula seja efetiva. Em conservatórios e outras instituições especializadas no ensino de música, as propostas criativas acabam ocupando lugar secundário devido ao foco no desenvolvimento de habilidades técnicas que a formação de instrumentistas e cantores demanda. Na educação básica, a própria presença da educação musical não é generalizada e, quando constituinte dos currículos, nem sempre as práticas de criação são frequentes (FONTERRADA, 2015).

Em meio à recente valorização, ao menos nos escritos acadêmicos, observa-se ainda que a criação em meio às proposições de educação musical são bastante diversas no que diz respeito à justificativa, fundamentação teórica, procedimentos didáticos, etc. (FONTERRADA, 2015). Essa variedade não é característica apenas da produção recente brasileira, mas já apontada por Beineke (2009) em relação a trabalhos acadêmicos de outros países e desde décadas anteriores. Há uma ampliação de fundamentação e objetivos nas pesquisas sobre criatividade e ensino de música, partindo de um cenário em que os estudos estavam mais concentrados no âmbito da psicologia do desenvolvimento - décadas de 1980 e 1990 - para uma diversidade 
teórica e metodológica que passou a englobar referenciais advindos da sociologia, antropologia, entre outras áreas.

Além da diversidade apontada no cenário de produção acadêmica, o estímulo aos processos criativos aparece também de maneira heterogênea quando analisamos propostas de educação musical que tiveram e têm circulação nacional e internacional desde a transição do século XIX para o século XX, até os dias atuais. Neste trabalho temos como foco a educação musical direcionada a grupos de crianças e que tem por objetivo a promoção da aprendizagem musical generalizada - porque não pautada no desenvolvimento de uma habilidade exclusiva, como o canto ou a performance de um instrumento específico -, tal como a área vem advogando por seu espaço na educação básica. Assim, a aprendizagem musical é constituída por diversas atividades além da prática instrumental e do canto, como escuta, criação de arranjos, composição de peças e canções, musicalização de histórias, jogos de improvisação, integração com outras linguagens artísticas, etc.

Partindo dessa especificação do que tomamos aqui por educação musical, é possível apontar uma série de propostas surgidas no largo período supracitado e que, de maneiras peculiares, lidam com as práticas criativas. Suas distinções se dão de modo mais explícito nos direcionamentos didáticos e, de modo mais velado, nas ideias de música, de educação e de infância sobre as quais se estabelecem. Estas ideias configuram-se de acordo com o momento histórico, os cenários geográficos, as relações entre estética e pedagogia, entre inúmeros fatores. Suas distinções nem sempre são óbvias e não levá-las em consideração pode ocasionar a apropriação descontextualizada de métodos e abordagens.

Com o intuito de clarificar a alegação de tal diversidade de configurações que pode ser percebida por trás das propostas de educação musical que, em alguma medida, reclamam-se como criativas, apresentamos uma explanação breve sobre as especificidades de dois nomes exemplares da área no último século, a saber, Carl Orff e François Delalande. Não é nosso objetivo apresentar tais propostas em seus detalhes, mas apenas exemplificar como as práticas criativas podem ser tomadas de maneiras bastante diferentes a depender de seus pressupostos, sobretudo estéticos.

A importância do primeiro educador se dá pela observação da grande quantidade de atividades de formação de professores engendradas por grupos com declarada filiação ao músico alemão. Essas atividades são recorrentes no Brasil, por 
meio de cursos e encontros da Associação ORFF Brasil - ABRAORFF - ${ }^{5}$, em sua organização central e também em grupos regionais; tal como em diversos países, destacadamente Estados Unidos, Espanha e Áustria. Observa-se ainda a presença expressiva de trabalhos com fundamentação declarada na abordagem orffiana constituintes da penúltima conferência ${ }^{6}$ da International Society for Music Education - ISME - tanto em discussões teóricas quanto em oficinas de formação didática. Em relação ao segundo, é notável a influência de seu pensamento educacional nos RCNEI, bem como seu papel de destaque no Groupe de Recherches Musicales GRM - do Institut National de l'Audiovisuel - INA, centro de grande importância para a música experimental na segunda metade do século passado. O autor teve produção científica significativa nas décadas de 1980 e 1990, atuando principalmente com temas como exploração sonora, primeira infância e música concreta. Seus trabalhos vêm sendo difundidos através de colaboração em países europeus e também na América do Sul.

Tanto a abordagem de Orff quanto a de Delalande levam em conta a necessidade de abertura para exploração e criação das crianças em seus processos de construção de conhecimento (BONA, 2011; GRAETZER, YEPES, 1983; DELALANDE, 1988; 1995; DELALANDE, FRAPAT, 1986). Ambos dedicaram-se à tarefa de pensar a educação musical como acontecimento na infância e advogam tratar da música mais apropriada para esta fase da vida. No entanto, suas proposições podem ser consideradas antagônicas em muitos pontos.

Partindo de aspectos didáticos, que são os aspectos mais explícitos de uma proposta pedagógica, a distância entre os dois é bastante evidente. Em relação ao papel do educador, este é sobretudo um organizador de materiais musicais na proposta orffiana. O ensino é pautado na sequência de materiais musicais com os quais as crianças lidam, como a seleção de células rítmicas ou a acumulação de intervalos no caminho de apropriação de escalas. O educador seleciona e apresenta os materiais para os alunos, cuja atividade - criativa ou não - será uma etapa na aprendizagem de um sistema musical.

\footnotetext{
${ }^{5}$ É possível ter acesso a informações e atividades do grupo em seu site: http://www.abraorff.org.br/ Acesso em 31 mar. 2019.

${ }^{6}$ 32nd World Conference - International Society for Music Education. Realizada em Glasgow - UK, entre 24 e 29 de julho de 2016. Informações em https://www.isme.org/other-publications/proceedingsismes-32nd-world-conference-glasgow-scotland-2016 Acesso em 31 mar. 2019.
} 
O educador musical, em uma proposta baseada nos trabalhos de Delalande, estaria mais comprometido com a promoção de oportunidades para as crianças explorarem materiais sonoros diversos. Além da criação de condições de exploração, o educador aparece como um guia que contribui para que as relações que as crianças estabelecem com e entre os sons possam se tornar mais complexas.

Essa diferença concernente ao papel do educador está diretamente ligada ao que é tomado como material musical nas duas propostas. Na abordagem orffiana, a aprendizagem passa pelo acúmulo de materiais musicais com os quais as crianças lidam. Em atividades criativas, de improvisação ou composição, parte-se sempre de uma quantidade limitada de notas ou de possibilidades rítmicas, às quais se somam outras possibilidades com o passar do tempo. Estes materiais são relações - entre alturas, na organização de escalas; entre durações, na organização de padrões rítmicos; entre seções, na organização formal - e estas são manipuladas para serem aprendidas pelas crianças. Nos trabalhos de Delalande, que tem ligação direta com a música concreta, o material não está previamente determinado, podendo ser tomado de qualquer fonte sonora. É o processo de estabelecer relações com e entre os sons, de variadas maneiras, que caracterizaria as condutas musicais. Estas passam pelo estabelecimento de regras internas aos discursos musicais, bem como pela associação com fatores externos, podendo ser observadas em pesquisas experimentais mais do que definidas de antemão.

Porque orientadas por diferentes pressupostos estéticos, essas duas abordagens assumem características completamente distintas, ao que poderíamos ainda acrescentar diferenças epistemológicas ou variadas maneiras de encarar a educação. $\mathrm{O}$ exercício de analisar diversas propostas pedagógico-musicais caracterizadas pelo viés das práticas criativas, apontando suas discrepâncias didáticas e de fundamentação, poderia se desdobrar de maneira verdadeiramente extensa. Cada proposta está ligada a uma rede de relações onde subjazem ideias de música, de educação e de infância, e que pode torná-las substancialmente diversas.

Em relação aos motivos que levam à inserção das práticas criativas nos currículos escolares, Barret (2003 apud BEINEKE, 2009) apresenta como centrais os seguintes: (1) proporcionar experiências criativas a todos os estudantes; (2) introduzir os estudantes em técnicas e materiais da música contemporânea; (3) desenvolver pensamento e compreensão musical e (4) ensinar a compor para formar compositores. A esses, Beineke (2009) ainda acrescenta outros argumentos a favor da aprendizagem 
criativa em música, como promover o desenvolvimento de senso crítico e da capacidade de intervenção e transformação; a possibilidade de compreensão e criação de significados de maneira mais ativa em trocas simbólicas; a abertura para interações com as vivências musicais dos estudantes externas à escola; entre outros.

Ao levarmos em consideração a grande variedade de fundamentações e justificativas para as atividades criativas em educação musical, a assunção das abordagens expostas - ou de tantas outras - como base para a formação e o trabalho de educadores deveria ir muito além do treinamento de habilidades didáticas e predeterminação metodológica. Tendo em vista a valorização das práticas criativas em meio aos discursos sobre educação musical e os esforços políticos que pretendem garantir a efetiva presença da área na educação básica, a tarefa de analisar os pressupostos em que se baseiam as propostas pedagógicas parece necessária. Além disso, consolidar a educação musical como parte fundamental da formação de cidadãos, optando por planos de ensino que não negligenciem atividades de composição e improvisação, depende sobretudo da capacidade de sua articulação com pressupostos mais amplos para a escola de educação básica.

Em relatório mundial publicado pela Unesco em 2016, intitulado Education for people and planet: creating sustainable futures for all, a instituição publicou dados discutidos no Fórum Mundial de Educação realizado no ano anterior. O evento teve como temática central a equidade de educação de qualidade em diferentes países. Quando trata da qualidade da educação, numerosas são as menções a habilidades como colaboração, pensamento crítico e criatividade como centrais para a melhoria global da educação nos próximos anos. Essas habilidades são consideradas fundamentais, no entanto, no próprio relatório, apresentadas como “ ainda difíceis de definir, avaliar e ensinar" (UNESCO, 2016, p. 248). Reiteramos, então, que estes temas, ao mesmo tempo que ocupam de maneira central os discursos sobre educação, necessitam de reflexão constante sobre seus fundamentos como parte das condições de sua realização.

Em tese que resultou de uma extensa pesquisa sobre o movimento educacional renovador em curso no Brasil no início de século XXI, Barrera (2016) aponta a criatividade como um dos objetivos pedagógicos, aparecendo através de práticas e concepções variadas. A valorização da criatividade aliada ao apelo à centralidade da criança no processo educativo, segundo a autora, não é apenas característica das ideias pedagógicas em voga na atualidade, mas constitui um dos pontos de 
convergência entre o momento que vivemos e o cenário escolanovista brasileiro e internacional das décadas de 1920 e 1930.

O ideário do movimento de renovação escolar que se estabeleceu no início do século XX no Brasil circulava vigorosamente entre diversos países. Suas produções teóricas e experiências pedagógicas tinham lugar principalmente em países da Europa, nos Estados Unidos e na então União Soviética, mas muitos materiais e experimentos também foram produzidos em outros lugares, como a América Latina. Segundo Cambi (1999), os grandes temas de tal tendência pedagógica eram os seguintes: (1) o puericentrismo, como reconhecimento do papel central e ativo das crianças nos processos educativos; (2) a valorização do "fazer" na aprendizagem, que leva à priorização de atividades manuais, do trabalho e do jogo; (3) a motivação, conferindo importância ao interesse das crianças e às suas necessidades práticas, emocionais e cognitivas; (4) o estudo de ambiente, que se caracteriza pela assunção do espaço de vivência dos estudantes como estimulador da aprendizagem; (5) a socialização, como uma das necessidades das crianças a ser suprida e aprimorada no processo educativo ${ }^{7}$; (6) o antiautoritarismo, como tentativa de reformulação das relações na escola e (7) o anti-intelectualismo, que levava à reavaliação de programas e conhecimentos.

Como veremos mais adiante na presente tese, a existência de temas comuns, como os apontados por Cambi (1999), não significa que os movimentos de renovação escolar tenham se desdobrado sem conflitos e contradições. Pelo contrário, as justificativas para a centralidade destes temas e a sua realização em projetos pedagógicos eram heterogêneas. Sobre seus fundamentos, o cenário faz convergir a ascendência rousseauniana (CAMBI, 1999; SAVIANI, 2008), o credo científico positivista (MONARCHA, 2009), além de direcionamentos políticos marxistas, liberais e anarquistas (GADOTTI, 2013), tratando-se, portanto, de objeto de grande complexidade.

Não seria prudente afirmar aqui que o movimento Escola Nova foi o fundador da valorização da criatividade na educação. Reclamar uma postura vanguardista sempre abarca o problema de lidar com a pretensão de originalidade, o que pode levar a asserções demasiado simplificadoras. Entretanto, mesmo que não caracterizemos o cenário escolanovista como ponto de origem da criatividade na educação, é

\footnotetext{
${ }^{7}$ A ideia de que o processo de socialização das crianças estaria centralizado na escola já não é aceita atualmente. Para um estudo sobre a revisão bibliográfica acerca do conceito de socialização, bem como considerações sobre o caráter inacabado e dialético do processo de construção de disposições internas que permitem e orientam as práticas sociais dos indivíduos, consultar Abrantes (2011).
} 
contundente a avaliação de que se trata de um momento da história das ideias pedagógicas no qual foi amplamente difundida a valorização da atividade criativa dos educandos.

Além dos aspectos evidenciados nos trabalhos de Barrera (2016) e Cambi (1999), a ligação entre promoção de processos criativos no ensino e as ideias de renovação escolar é apontada como fundamental para a história recente da educação brasileira na seção de Arte dos PCN. O documento apresenta como marcantes para o ensino da disciplina as "tendências tradicionalista e escolanovista" (BRASIL, 1997, p. 25) desde o início do século $X X$ até o momento de sua redação. Em relação às mudanças provocadas pela segunda tendência, podemos ler:

Entre os anos [19]20 e [19]70, as escolas brasileiras viveram outras experiências no âmbito do ensino e aprendizagem de arte, fortemente sustentadas pela estética modernista e com base na tendência escolanovista. $O$ ensino de Arte volta-se para o desenvolvimento natural da criança, centrado no respeito às suas necessidades e aspirações, valorizando suas formas de expressão e de compreensão do mundo. As práticas pedagógicas, que eram diretivas, com ênfase na repetição de modelos e no professor, são redimensionadas, deslocando-se a ênfase para os processos de desenvolvimento do aluno e sua criação (BRASIL, 1997, p. 26)

Quando se trata especificamente da linguagem musical, a primeira tendência é associada ao Canto Orfeônico, que vigorou entre as décadas de 1930 e 1960 e, por conta de dificuldades de realização do projeto original, "acabou transformando a aula de música numa teoria musical baseada nos aspectos matemáticos e visuais do código musical com a memorização de peças orfeônicas" (BRASIL, 1997, p. 26). Como contraposição ao Canto Orfeônico e associado à tendência escolanovista, teria surgido um ensino de música com

outro enfoque, quando a música pode ser sentida, tocada, dançada, além de cantada. Utilizando jogos, instrumentos de percussão, rodas e brincadeiras buscava-se um desenvolvimento auditivo, rítmico, a expressão corporal e a socialização das crianças que são estimuladas a experimentar, improvisar e criar (BRASIL, 1997, p. 27)

Fonterrada (2008), porém, aponta a falta de conexão destas novas abordagens em educação musical com a escola de educação básica. Segundo a autora, Liddy Chiafarelli Mignone, Sá Pereira, Gazy de Sá, entre outros educadores, trabalharam de maneira a incluir diversas habilidades nas aulas de música em grupo, e não apenas 
privilegiar o canto ou um instrumento, com abordagens inspiradas nos trabalhos de educadores europeus, como Edgar Willems, Jacques Dalcroze, Carl Orff, etc. Contudo, os educadores musicais brasileiros atuavam em escolas especializadas, sem atingir diretamente a escola regular, cuja prática, de acordo com a autora (2008), não mudou substancialmente nem mesmo com a troca do termo "Canto Orfeônico" por "Educação Musical" na década de 1960. Ao que acrescentamos que, mesmo no exterior, muitas dessas propostas tiveram como locus de seu desenvolvimento escolas e cursos especializados, não sendo direta sua ligação com a educação básica.

Tratando a Educação Musical em nível internacional e tomando o século XX como momento de estabelecimento da área tal qual a concebemos hoje, Fonterrada (2008) e Gainza (2009) defendem a existência de dois pontos estruturantes. Para estas autoras, no início do século passado as propostas caracterizaram-se por alguns traços de inovação, como as aulas em grupo e com foco em promover o desenvolvimento musical global, de maneira a integrar diversas habilidades; a preocupação com direcionamentos didáticos apropriados à infância; o uso do corpo; o incentivo à iniciação musical através de práticas, em detrimento de aulas teóricas. Essas propostas já permitiam uma atitude mais ativa por parte dos alunos, mas foi apenas na segunda metade do século, notadamente a partir da década de 1960, que educadores/compositores propuseram de maneira efetiva a aproximação entre crianças e música através de atos criativos, levando em conta a espontaneidade e a indeterminação do fazer musical na infância aliadas às ideias estéticas em voga (FONTERRADA, 2008; 2015).

As décadas de 1960 e 1970 foram, no Brasil, um período de difusão de abordagens criativas por meio das Oficinas de Música do Instituto Villa-Lobos, no Rio de Janeiro, e na Universidade de Brasília. Essas atividades aconteceram por iniciativa de alguns músicos/professores como Reginaldo de Carvalho, Emílio Terraza, Conrado Silva, Luiz Botelho e Luiz Carlos Czéko. Ainda em outros lugares do Brasil as atividades criativas chegaram através do trabalho de H. J. Koellreutter, grande responsável pela abertura criativa na formação de músicos e educadores, bem como pela revisão do pensamento pedagógico musical no meio acadêmico de então.

Entretanto, Fonterrada (2015) aponta que, mais uma vez, os avanços na educação musical estiveram circunscritos a um cenário específico. 
à composição, infelizmente não se chegou a perceber fortemente sua influência nas escolas especializadas em música (conservatórios e escolas livres) e nem nas escolas brasileiras de ensino fundamental e médio (FONTERRADA, 2015, p. 18)

Enquanto a abertura para processos criativos na educação musical parece não conseguir encontrar caminhos para influenciar de maneira significativa o ensino da linguagem na escola de educação básica brasileira, mesmo que presentes nos documentos oficiais, as artes visuais deram mostras de maior consonância com as ideias pedagógicas reformadoras. Barbosa (2001) analisa principalmente a influência do pensamento de John Dewey no ensino de artes visuais brasileiro, além de apontar também a presença de autores dos movimentos escolanovistas europeus.

Um dos casos que a autora apresenta é a influência dos estudos de Nereu Sampaio nas reformas da instrução pública no final da década de 1920 e nos anos 1930, cuja tese defendida em 1929 na Escola Normal do Distrito Federal intitulava-se Desenho espontâneo das crianças: considerações sobre a sua metodologia. Este trabalho estava declaradamente baseado no pensamento de John Dewey, o mais importante autor de vertente renovadora da pedagogia estadunidense. A influência do trabalho de Sampaio deu-se, segundo Barbosa (2001), através de Edgar Sussekind de Mendonça, organizador do programa de artes e desenho de reformas da instrução pública e um dos examinadores da tese de Sampaio. Convencido da excelência do método de Sampaio, Sussekind de Mendonça introduziu-o ainda em algumas escolas.

Não apenas as artes visuais experimentaram abertura aos processos criativos infantis em sua relação com o pensamento pedagógico reformador, mas também o ensino da escrita assim se direcionou. Em divulgação dos trabalho de Sussekind de Mendonça e Sampaio, Venâncio Filho apresenta o então atual pensamento sobre o ensino dessas duas áreas

O desenho é a disciplina que se vae, a cada passo, impondo no conjuncto da cultura. Outrora, e não há muito, era apenas privilegio de alguns, que tinham geito... Hoje, maneira de expressão, como a escripta, todos devem aprender e podem praticar (VENÂNCIO FILHO, 1933, p. 131)

Tal citação consta no Notas de Educação, compilado de textos que Venâncio Filho publicou no início dos anos 1930 principalmente no Boletim de Educação Pública do Distrito Federal e onde se pode observar de maneira clara a força das 
ideias escolanovistas no debate público sobre educação no Brasil. Dentre os artigos ali reunidos, constam indicações de iniciativas de publicações de livros com textos feitos por crianças em diferentes países.

Em alguns países estrangeiros, a aprendizagem da escrita e do desenho através de processos criativos é acompanhada pela especial valorização destes. Como apontado por Venâncio Filho (1933), no início do século passado e entre os movimentos de renovação escolar existiram algumas publicações compostas por textos e, por vezes, ilustrações das próprias crianças. Pudemos observar produções de tal natureza em pesquisa desenvolvida no mestrado (MOREIRA, 2014) a respeito do ensino de música no Movimento Escola Moderna - popularmente conhecido como Pedagogia Freinet. A constituição e a expansão do referido movimento originalmente francês na década de 1920 se deu, principalmente, pela veiculação do trabalho desenvolvido com crianças em sala de aula. Entre as produções infantis, destaca-se a revista La Gerbe, publicada entre 1926 e 1946, que veiculava principalmente os textos livres - em todas as suas formas, incluída a poesia - das crianças do movimento, entre outras produções (FREINET, 1976). Também em língua francesa, temos a revista L'Oiseau Bleu, organizada e publicada por Roger Cousinet entre 1922 e 1929, com textos feitos por e para crianças. No caso de Cousinet, tanto na revista quanto em suas considerações sobre o desenho, a abertura para os processos criativos na infância tinham por motivação maior a observação do comportamento infantil com um viés científico (GUTIERREZ, 2007; COUSINET, 1922).

Voltando ao caso do Brasil e dos processos criativos na educação de linguagens artísticas, um movimento notável se iniciou em 1948, no Rio de Janeiro, e se expandiu para outros estados, a saber, o Movimento das Escolinhas de Arte. A experiência começou com um grupo pequeno de crianças e focando em atividades de livre-expressão através da arte, por iniciativa de Augusto Rodrigues, Margaret Spencer e Lucia Alencastro Valentim (COSTA, 2010). Além das atividades com crianças, as escolinhas se tornaram espaço de pesquisa e formação de professores. As atividades se estenderam pelo país e no exterior, desdobrando-se em eventos como conferências, palestras e exposições. O movimento baseava-se principalmente nos trabalhos de Herbert Read e Franz Cizek, mas Ferraz e Fusari (2009) o apresentam como manifestação, no ensino de arte do Brasil, das ideias escolanovistas e do movimento modernista, pelo seu foco na expressão livre e no desenvolvimento infantil. No trabalho destas autoras, assim como nos PCN, a Iniciação Musical é 
apresentada em contraposição ao Canto Orfeônico como expressão da oposição entre tendência escolanovista e tendência tradicional na área de música.

Liddy Chiaffarelli Mignone - que vinha trabalhando de maneira inovadora com crianças em um curso de Iniciação Musical desde 1937 no Conservatório Brasileiro de Música (ROCHA, 2017) - realizou, em 1949 e ao lado de Augusto Rodrigues, a Semana da Criança, com discussões públicas sobre arte e infância. Paz (2013, p. 62 - 63) nos apresenta um trecho de entrevista concedida por Ruth Paramis à Cecília Conde, onde a entrevistada comenta o que testemunhou no evento

A conclusão era de que a criança vivencia muitos ritmos e melodias, porém, em comparação com as outras artes, pouco criava: precisava se valorizar a criação numa linha simples como, por exemplo, a criação de células rítmicas

Propostas de iniciação musical como de Liddy Mignone e Sá Pereira, por exemplo, já levavam em consideração ao menos alguns aspectos do aporte pedagógico que circulava com o ideário escolanovista (PAZ, 2013). Porém, ao que parece, assim como os métodos de educação musical europeus da primeira metade do século XX ainda hoje amplamente divulgados, não conseguiram realizar uma efetiva abertura para os processos criativos das crianças. Um caso exemplar é a afirmação de que "acreditar que a criança é realmente criadora" é uma tendência perigosa e exagerada (WILLEMS, 2002, p. 25). Tal afirmação aparece logo após Willems defender que a educação musical estaria em melhor situação que qualquer outra disciplina para realizar os princípios da educação nova. A aproximação com as tendências pedagógicas renovadoras parece, aqui, muito mais relacionada aos estudos de psicologia como fundamentos de algumas mudanças de direcionamento didático. As ideias de música e de educação que fundamentam a prática de ensino não necessariamente foram atingidas de maneira substancial nestas propostas, evidenciando limites em seu caráter inovador.

Colocamo-nos, então, como problema da presente pesquisa, a compreensão das relações entre o desenvolvimento do pensamento pedagógico no início do século XX - quando proporcionou a assunção de um papel central e ativo para as crianças nos processos de ensino e aprendizagem - e a educação musical. Mesmo que seja evidente a incorporação dos processos criativos infantis na educação musical após a Segunda Guerra Mundial, quando impulsionada por proposições advindas do campo da estética, a presente pesquisa explora a hipótese de que em meio a movimentos 
escolanovistas este tema já era caro aos educadores e já encontrava meios de realização em sala de aula e de circulação em debates pedagógicos ainda no período entre-guerras.

Visto que, como apresentado anteriormente, a educação musical deu mostras de estar em descompasso com o pensamento pedagógico mais progressista, atentamos para a diferença dos espaços retratados nestes discursos. Os métodos ativos, reconhecidos como inovadores em alguma medida, têm como lugar de desenvolvimento, por excelência, a escola de música ou os cursos livres. $\mathrm{O}$ movimento escolanovista, por sua vez, como seu próprio nome evidencia, diz respeito substancialmente a mudanças na forma de encarar a instituição escolar na sociedade em sua constituição geracional e de relação com a cultura. Sendo assim, acreditamos que a operação de desviar o olhar dos métodos ativos e procurar os traços de inovação da educação musical quando inserida em movimentos pedagógicos de educação escolar nos proporcionaria um alargamento do conhecimento histórico da área. Investigamos, então, através de revistas pedagógicas de cunho renovador publicadas nas décadas de 1920, 1930 e 1940, se e como a música se encontra em coerência com estes projetos pedagógicos.

Ao tratar de tais proposições, assumimos que a presente pesquisa é de cunho histórico, visto que busca elucidar o desenvolvimento das ideias de educação musical no decorrer do tempo. Para tanto, determinamos como perguntas centrais da pesquisa a serem respondidas, as seguintes:

Existiram, em meio aos movimentos escolanovistas, propostas de educação musical nas quais os processos criativos infantis foram efetivamente valorizados? Quais ideias de educação musical e de criatividade circularam neste cenário específico?

Conscientes da heterogeneidade do quadro sobre o qual nos debruçamos, dedicamos as páginas seguintes a considerações sobre a possibilidade de tratá-los como pertencentes a uma rede internacional ao mesmo tempo em que salientamos que sua harmonia não é total. Examinemos, então, algumas características e as dificuldades de definição do que correntemente denomina-se escolanovismo. 


\subsection{Novidade e Progresso: polifonia internacional e a negação como}

consenso

O movimento internacional de renovação escolar do início do século XX não se presta a definições breves ou totalizantes. E isso porque se estabeleceu como uma rede de educadores em diversos países, com fundamentações e posicionamentos políticos também diversos. Trata-se de um quadro de ebulição de propostas pedagógicas contemporâneas entre si, expressando os desafios de lidar com a infância e os processos de escolarização em cada contexto.

De maneira condizente com a falta de concordância e unidade e pela sua grande abrangência, surgem termos como "polifonia" (GUTIERREZ, SAVOYE, 2018) e "mercado planetário de ideias" (MONARCHA, 2009) nos estudos sobre os movimentos. Gutierrez e Savoye (2018) falam de "polifonia" quando se dedicam a examinar as contribuições de uma figura em particular - Madeleine Guéritte, cujo trabalho será apresentado em nosso capítulo 3 -, demonstrando como era, ao mesmo tempo, original e conectada com outros agentes. A imagem de relação polifônica nos parece muito acertada, sobretudo em se tratando do estudo de um indivíduo em relação ao seu meio, pois dá a ver uma situação coletiva construída a partir de colaborações particulares.

O uso do termo "mercado planetário de ideias" por Monarcha (2009) refere-se tanto à conectividade global que se alcança com os Congressos Internacionais de Educação Nova a partir do início da década de 1920 - tema que também será abordado em nosso capítulo 3 -, quanto à intensa atividade editorial característica do momento. Em suas palavras:

Quaisquer que sejam as interpretações algo é inegável: os ideais de educação funcional e seus métodos assumiam crescente caráter de internacionalização e cosmopolitismo, o léxico e as fórmulas internacionalizavam-se, configurando um mercado planetário de ideias [...].

Produção editorial massiva e imprensa pedagógica de propaganda trivializavam o programa da Liga [Internacional pela Éducação Nova] junto ao grande público, por vezes mobilizando-o. A rede de contatos pessoais, publicações e conferências, mantinham o público atualizado nas conquistas e avanços das ciências da educação (MONARCHA, 2009, p. 57 - 58, grifo no original) 
Esses autores nos ajudam a ver que a abrangência internacional do quadro e a grande quantidade de agentes particulares, conectando-se através de eventos e produção impressa, resultam em uma situação onde unidade e heterogeneidade não são exatamente opostas, tampouco se sobrepõem sem conflitos.

Os conflitos, próprios de um quadro em que não há coesão total, eram enfrentados pelos próprios integrantes desses movimentos e seus contemporâreos. Hameline (2004a) nos mostra que, já em 1910, o historiador Jules Dubois apresentou uma tese em que a pedagogia da passagem do século XIX para o século XX mostra-se como um conjunto de tendências que, ainda que diversas, marcavam a busca de uma educação nova para um tempo novo. Este trabalho foi apresentado à Universidade de Genebra, centro de grande importância para os desdobramentos do movimento renovador pedagógico europeu, e tinha por título $O$ problema pedagógico, ensaio sobre a colocação do problema e a busca pelas suas soluções.

A tensão entre unidade e pluralidade se mostrava nas práticas pedagógicas engendradas, nas ações políticas e nos discursos produzidos pelos educadores. Assim, logo no início do estabelecimento de conexões, sobretudo internacionais, ensaiaramse definições e, portanto, limites. Neste sentido, por exemplo, Adolphe Ferrière, intentando recensear escolas experimentais na Europa nas primeiras décadas do século XX, define e redefine suas características e limites em textos como boletins publicados na revista Pour l’Ère Nouvelle - publicação francófona da Liga Internacional pela Educação Nova e, na década de 1920, editada pelo próprio Ferrière -, em outras revistas escolanovistas e em vários livros, traduzidos em todo o mundo. O termo que adota é Escola Ativa que, segundo Hameline (2004b), através da grande produção textual de Ferrière, toma ares de slogan, em contraposição ao que ele e outros educadores chamavam vagamente de educação tradicional. Em Prefácio de seu livro Três pioneiros da Educação Nova, vemos alguns traços apontados por Ferrière (1928) como sendo os principais pontos de engajamento do movimento de renovação escolar : (a) o descontentamento com a escola antiga; (b) o desejo de preparar as crianças e os adolescentes à vida de hoje e, se possível, de amanhã; (c) o progresso da ciência e, particularmente, da psicologia infantil; (d) os múltiplos experimentos de educadores em escolas públicas. Nesta Introdução também lemos que o movimento tem como característica a origem no próprio corpo de educadores e a concatenação de teoria e prática. 
Também Roger Cousinet, educador de grande importância e cujo trabalho aparecerá posteriormente na presente tese, se dedicou a clarificar os pontos de unidade e pluralidade do movimento. Em seu livro Educação Nova, lemos que: “[...] um certo número de correntes se uniram para criar essa concepção particular da educação que nomeanos educação nova e a psicologia infantil constitui uma, apenas uma, dentre as correntes" (COUSINET, 1968, p. 24). O autor empreende, então, uma classificação de três correntes - mística, filosófica e científica - na qual organiza as contribuições de diversos autores correntemente associados ao assunto - como Rousseau, Dewey, Tolstoi, Binet, etc. -, marcando seus pontos em comum e suas inclinações particulares. Essas correntes confluem, segundo o autor (1968), para o desenvolvimento dos movimentos internacionais de educação nova do entre-guerras. Além de expor as diferentes influências e alguns exemplos de educadores fundamentais para sua organização didática, como Maria Montessori e Ovide Décroly, Cousinet se arrisca a dizer o que é a educação nova. Desejando não fechar o conceito em uma proposta pedagógica ou corrente unívoca, Cousinet é demasiadamente vago ao afirmar que a educação nova não é um método, "ela é essencialmente uma atitude para o educador e um modo de vida para as crianças" (Idem, p. 88).

Apontamos ainda outra tentativa de definição em texto da revista francesa $L a$ Nouvelle Éducation onde se apresenta o movimento estadunidense. Além de citar os educadores envolvidos e algumas ações, lemos que a escola nova se diferencia da escola antiga na medida em que toma a autonomia dos educandos como determinante dos processos de aprendizagem: "se os estudantes são incumbidos ativamente de se educarem a si mesmos, temos uma escola nova; mas se as crianças esperam passivamente que um mestre venha lhes instruir, então temos uma escola velha, por mais nova que ela possa ser" (L’ÉDUCATION, 1924, p. 134, grifo no original). A tarefa da escola, nesse novo contexto, passa a ser "ajudar os indivíduos a viverem uma vida de atividade criadora" (1924, p. 135). Não há clareza, contudo, sobre o que é uma atividade criadora ou sobre a relação entre autonomia nas atividades escolares e a construção da autonomia de uma maneira mais ampla.

O movimento passa por mudanças e reformulações ao longo de sua história, como será dado a ver no decorrer da tese e em sua relação com o tema da educação musical. Os conflitos se acirram sobretudo na década de 1930 e a pretensão de total 
unidade se mostra cada vez mais distante da realidade, sobretudo em relação ao enfrentamento das tensões políticas que antecedem a Segunda Guerra Mundial.

As tentativas de definição são abudantes na literatura produzida no contexto e, mesmo que difusas e tentando sublinhar características distintas como centro do movimento, apresentam um traço peculiar em comum: recorrem à negação. Saviani (2008), em crítica muito conhecida aos pressupostos mais disseminados como slogans da Escola Nova, como sua relação indiscrimada com a democracia e a ciência, vale-se da "teoria da curvatura da vara" (Idem, p. 30). O autor explica que esta teoria era atribuída por Althusser a Lênin que, ao ser criticado por posições demasiadamente extremas e radicais, teria respondido: "quando a vara está torta, ela fica curva de um lado e se você quiser endireitá-la, não basta colocá-la na posição correta. É preciso curvá-la para o lado oposto" (ALTHUSSER apud SAVIANI, 2008, p. 30). O autor se vale dessa imagem ao construir uma crítica pungente à Escola Nova, curvando a vara para o lado oposto com o objetivo de chegar a uma proposta que ultrapasse os limites tanto da Escola Nova quanto da chamada Escola Tradicional.

Não intentamos aqui discutir, tampouco marcar um alinhamento a tal crítica, pois nossa investigação não toma a Escola Nova como objeto acabado ou a ser superado, e sim como objeto a ser investigado no que não se mostra evidente, tateando para além de seus slogans. O que nos interessa nessa crítica de Saviani é a percepção de que um dos pontos mais claros de unidade entre os variados movimentos escolanovistas é a sua oposição ao que denominam escola tradicional. Há ainda outros termos, como escola antiga, marcando sempre uma condição antiquada a ser combatida, combate este em que o movimento renovador aparece como ruptura. Esses movimentos se autodenominam progressistas e novos, inscrevendo-se na história da educação, mais precisamente, na história da educação escolar.

Assim como as autodefinições destes educadores são vagas, também o são as tentativas de dizer o que é a escola à qual se opõem. Alguns pontos dessa rejeição conclamada pelos renovadores nos são expostos por Haenggeli-Jenni (2012), em trabalho sobre os debates em torno de definições e conceituações na revista Pour l'Ère Nouvelle. São eles: (a) em relação ao professor: os renovadores se opõem à imagem de professor transmissor de saberes, ao que substituem a ideia de aprendizagem que parte da criança; (b) em relação aos programas e saberes escolares: eles se opõem aos conteúdos rígidos, que classificam de dogmáticos. Propõem, então, 
que os conteúdos sejam revisados de acordo com sua coerência com o contexto social, com o mundo contemporâneo, levando em consideração as necessidades das crianças; (c) em relação à autoridade e disciplina: confrontam a hierarquia em que a disciplina é provida pelo professor, reivindicando relações de cooperação e que a disciplina seja gerenciada coletivamente; (d) em relação aos métodos: pretendem substituir o ensino unidirecional, que parte do professor, pela organização de ateliês e trabalho em grupo, nos quais os alunos poderiam colaborar entre seus pares.

Esse esforço de se definir pela negação opera como representação de ruptura para os movimentos e permite, segundo Jenkis (2000), que a crítica ao antigo se apresente como ênfase na valorização das novidades propostas. Para Haenggeli-Jeni (2012), a denúnica de coerção e mecanicidade atribuídas aos métodos antigos se alinha ao ímpeto pacifista do movimento. A escola tradicional é um conceito vago, mas decididamente atacado por esses educadores, pois eles buscavam uma educação que não mais levasse as próximas gerações à guerra.

Cientes da grande extensão que o movimento alcançou e das conflitantes forças epistemológicas e políticas que lhe serviam de base, não nos dedicaremos a elaborar uma definição precisa, pois tal tarefa nos parece pouco profícua. Partimos do pressuposto de que existem características fundamentais, como a internacionalização e a importância da imprensa pedagógica, para empreender a pesquisa da qual decorre a presente tese. Tanto estas quanto outras características dos movimentos históricos aqui focalizados serão clarificadas nos capítulos que se seguem, na medida em que os resultados da pesquisa forem expostos.

\subsection{Definindo o caminho: periodização, seleção de fontes, pressupostos} teóricos e metodológicos

Como argumentamos anteriormente, a valorização das práticas criativas na educação musical aparece de maneiras diversas ao longo do século XX e ainda hoje, tanto no que diz respeito aos direcionamentos didáticos, quanto às fundamentações e justificativas. Numerosas propostas privilegiam as atividades de composição e improvisação das crianças, contudo, seus limites diferem de acordo com vários fatores, como as ideias de música e de infância nas quais se baseiam. 
Considerar a valorização das práticas criativas em contexto pedagógico como fenômeno a ser compreendido em sua historicidade, leva-nos a tomar decisões sobre como proceder para melhor responder às perguntas que guiam a investigação.

Os movimentos de renovação escolar focalizados na presente tese são aqui observados, particularmente, sob o prisma de sua divulgação em imprensa pedagógica. As publicações Progressive Education, La Nouvelle Éducation e Revista Brasileira de Estudos Pedagógicos datadas das décadas de 1920, 1930 e 1940 são tomadas como fontes centrais da investigação e como porta de entrada para o estudo, visto que de sua leitura desdobraram-se leituras secundárias. Por meio deste material é possível observar não apenas conteúdos relacionados a áreas de conhecimentos específicos - em nosso caso, a educação musical -, mas também apreendem-se os traços de organização dos movimentos, bem como suas relações com o poder público. A esse respeito, salientamos que as revistas estrangeiras são publicações de organizações sociais envolvendo educadores e intelectuais, ao passo que a revista brasileira insere-se em um ambiente oficial, surgindo como publicação do Instituto Nacional de Estudos e Pesquisas Educacionais - INEP -, órgão do Ministério da Educação.

A opção por basear o trabalho em um corpo documental constituído por revistas tem como objetivo compreender como se dava a circulação das ideias pedagógicas escolanovistas entre três cenários: Europa, Estados Unidos e Brasil. Os dois primeiros confirmam-se como destacados polos de difusão deste ideário quando observamos a produção brasileira à época.

Em Notas de Educação, reunião de textos que Venâncio Filho (1933) publicou no início da década de 1930, constam dez traduções de artigos das revistas estrangeiras selecionadas aqui. Estas revistas também são indicadas nas sugestões bibliográficas fornecidas por Lourenço Filho (1929) em Introdução ao Estudo da Escola Nova, obra central para o cenário pedagógico da época ${ }^{8}$.

A análise da circulação de textos neste período em imprensa pedagógica se justifica pois, de acordo com Catani (1996),

\footnotetext{
${ }^{8}$ A grande influência de Introdução ao estudo da Escola Nova colocou Lourenço Filho em evidência no cenário intelectual. Trechos da obra foram traduzidos para diversas línguas, constando na imprensa pedagógica de vários países. Após a publicação, o autor foi convidado a colaborar na organização de obras como Dicionário de Pedagogia Labor, editado na Espanha em 1936, e Encyclopedia of Modern Education, publicada em Nova Iorque em 1943. Sobre mais detalhes a respeito da repercussão deste trabalho, consultar o Prólogo da Editora na $12^{\mathrm{a}}$ ed., datada de 1978, publicada pela Melhoramentos.
} 
De fato, as revistas especializadas em educação, no Brasil e em outros países, de um modo geral, constituem uma instância privilegiada para a apreensão dos modos de funcionamento do campo educacional enquanto fazem circular informações sobre o trabalho pedagógico e o aperfeiçoamento das práticas docentes, o ensino específico das disciplinas, a organização dos sistemas, as reivindicações da categoria do magistério e outros temas que emergem do espaço profissional. Por outro lado, acompanhar o aparecimento e o ciclo de vida dessas revistas permite conhecer as lutas por legitimidade que se travam no campo educacional. É possível analisar a participação dos agente produtores do periódico na organização do sistema de ensino e na elaboração dos discursos que visam a instaurar as práticas exemplares (CATANI, 1996, p. 117)

A imprensa pedagógica parece-nos fonte privilegiada para o exame de tais movimentos pelo fato de ser uma forma de publicação inerente à própria sociabilidade em questão. A existência de escritos sobre educação que remetem às ideias pedagógicas centradas na infância não são novidade no início do século passado. Tais ideias inscrevem-se no desenrolar de uma herança cuja origem não poucas vezes é atribuída à obra de Rousseau, Comenius, Fröbel, entre outros autores. Cabe ressaltar, no entanto, que até o final do século XIX e início do século XX, a difusão do ideário pedagógico estava sobremaneira centrada na produção de livros. O momento que investigamos aqui, por sua vez, tem como característica notável a organização de educadores e intelectuais comprometidos com a aplicação de tais ideias pedagógicas no âmbito da prática educativa em associações e outras entidades. Essa tendência à organização social e política em movimentos encontra sua forma de difusão e promoção de debates públicos na criação de revistas e boletins ${ }^{9}$, isso, evidentemente, somado a outras iniciativas de discussões presenciais, como assembleias e congressos, cujos conteúdos também figuram nessa imprensa específica. No Brasil, mesmo que a revista seja oficial, é uma publicação dominada por educadores e intelectuais alinhados ao ideário escolanovista até a década de 1960 (ROTHEN, 2005).

É importante notar que a RBEP - como via para a divulgação dos sistemas internacionais e com explícita inclinação às ideias escolanovistas - era, como advertido por Rothen (2005), um espaço de voz de um determinado grupo de intelectuais e políticos. Em suas primeiras décadas, os conteúdos das publicações

\footnotetext{
${ }^{9}$ Segundo Alix (2017), a invenção da imprensa rotativa em meados do século XIX faz despencar os preços dos jornais nos Estados Unidos. O autor apresenta tal mudança nos hábitos de consumo de informação da população estadunidense de uma maneira geral. Aqui, ressaltamos a novidade da abertura para a circulação de produção intelectual pedagógica não mais centrada no livro.
} 
eram encomendados e apenas em 1983 são apresentados procedimentos e normas para o envio de textos para publicação, o que revela o papel que a revista desempenhava até então como veículo de difusão exclusiva das ideias dos intelectuais ligados ao INEP e das influências internacionais destes agentes. Nóvoa (1998), em estudo sobre a Educação Comparada, aponta que a disciplina tem sido central para aqueles que têm como função liderar reformas, usando a comparação entre sistemas de educação, muitas vezes, para justificar seus projetos de lei. Seja de maneira positiva - mostrando a justeza de suas ações -, seja de maneira negativa - como denúncia de atraso -, a comparação com o "estrangeiro" é sempre mobilizada como elemento legitimador.

As décadas de 1920, 1930 e 1940 - escolhidas neste trabalho como foco para a compreensão da circulação de ideias em educação musical -, caracterizam-se não apenas pela profusão de experimentos e pesquisas pedagógicas renovadoras, mas especialmente pela afirmação da educação como assunto internacional. Os movimentos da Escola Nova que surgem logo após a Primeira Guerra Mundial, não apenas faziam frente às limitações do que chamavam de escola tradicional, como também eram expressão de um projeto de reconstrução das nações através da educação. Após a Segunda Guerra Mundial, os discursos políticos que tomam a educação como assunto internacional se consagram com a criação de organizações como a UNESCO e o Banco Mundial - ambas em 1945 - e a centralidade que estas passam a exercer no âmbito da pesquisa e das políticas educacionais (NÓVOA, 1998).

A criação do Bureau International de l'Éducation - organização que viria a ser posteriormente integrada à UNESCO - data de 1925. Segundo Nóvoa (1998), a criação do BIE mostra que, naquele momento, as trocas internacionais já não se davam apenas na esfera de reformas e políticas, mas passavam às organizações e movimentos educacionais. O desenvolvimento dos estudos de Educação Comparada à época se deu com base em constituição de bancos de dados sobre os sistemas nacionais e na pretensão de, através de análises estatísticas, formular conhecimentos objetivos. Assim, supostamente, criavam-se condições para avaliar o desenvolvimento dos países, bem como para efetivar ações políticas internacionais, por meio dos dados de seus sistemas de ensino. O modelo de escola ocidental difunde-se, mostrando-se como universal e pautando relações culturais e econômicas.

Ao pensar que, em nosso estudo, assumimos que Europa e Estados Unidos foram protagonistas incontestáveis da divulgação do ideário escolanovista no cenário 
internacional, defendemos que é necessário tomar como pressuposto o fato de que, como toda produção cultural, as ideias pedagógicas não são assimiladas de maneira unívoca. Portanto, para responder às perguntas da presente pesquisa, pretende-se compreender a rede que se forma a partir da circulação das ideias pedagógicas quando ligadas à criatividade e à educação musical, considerando que as mesmas não foram meramente importadas de maneira linear e buscando elucidar as particularidades que assumem em cada contexto nacional. É necessário, para isso, suspeitar tanto da originalidade quanto da homogeneidade dessas apropriações (GVIRTZ e CORIA, 2001), assumindo a circulação de ideias pedagógicas como um fenômeno complexo.

Tomar a valorização das tendências escolanovistas no Brasil como expressão de um cenário de forte influência cultural e econômica europeia e estadunidense, neste caso, conjuga-se com a busca do entendimento de como as ideias de modernismo cultural e modernidade socioeconômica ganham novas cores em nosso território. O processo mesmo de institucionalização do ensino e da aprendizagem, gerando a organização da vida escolar como forma de sociabilidade que constitui a infância, torna-se significativo, segundo Ariès (2011), a partir do final do século XVI na Europa. A instituição escolar, bem como seus movimentos de renovação no início do século XX, tenderam a generalizar-se em meio a outros numerosos traços constituintes da cultura ocidental.

Parece-nos profícuo, aqui, pensar que a apropriação das ideias pedagógicas no Brasil seria um processo de hibridização. Este conceito é definido e defendido por Canclini (2015) como meio de analisar os processos socioculturais, especialmente na América Latina, de maneira que se supere o dualismo na organização de conflitos, como quando se opera a partir da oposição norte-sul ou local-global. Segundo o autor (2015, p. XIX), entende-se por hibridização "processos socioculturais nos quais as estruturas ou práticas discretas, que existiam de forma separada, se combinam para gerar novas estruturas, objetos e práticas". Em nosso caso, mais do que considerar que as ideias em educação no Brasil se transformam com a influência estrangeira, abre-se a análise para a compreensão das maneiras pelas quais as ideias de música, criatividade e educação se combinam, articulando novas ideias nos três cenários que focalizamos: Brasil, Estados Unidos e Europa; pois, como será exposta nos capítulos seguintes, a comparação com o estrangeiro no sentido de validar as práticas inovadoras não é exclusividade do Brasil. 
O período que destacamos em nossa investigação - décadas de 1920, 1930 e 1940 - é, como já afirmamos, fundamental para a consolidação da educação como assunto internacional. No caso do Brasil, este período é exemplar na análise que Canclini (2015) faz dos processos de modernização da América Latina. O autor defende que, sem cumprir ideais como um desenvolvimento econômico que sustentasse a democratização de bens culturais, mas operando na manutenção de desigualdades por conta de diversos fatores explicitados em seu estudo, passamos por algumas ondas de modernização. Em relação com a presente investigação, destacamos as três seguintes:

No final do século XIX e início do século XX, impulsionadas pela oligarquia progressista, pela alfabetização e pelos intelectuais europeizados; entre os anos 20 e 30 deste século [a redação do texto se dá no século XX], pela expansão do capitalismo e ascensão democratizadora dos setores médios e liberais, pela contribuição de migrantes e pela difusão em massa da escola, pela imprensa e pelo rádio; desde os anos 40, pela industrialização, pelo crescimento urbano, pelo maior acesso à educação média e superior, pelas novas indústrias culturais (CANCLINI, 2015, p. 67)

Fica claro que, além de um movimento que aspirava renovação didática, a época é marcada fortemente pelo estabelecimento da escola como instituição central para a sociedade brasileira. O país, com alta taxa de analfabetismo ${ }^{10}$, apostava na instrução como fator decisivo para a construção verdadeira de uma república democrática. Também Estados Unidos e França, cada um a sua maneira, como será exposto nos capítulos seguintes, passavam por um momento de estabelecer uma organização social centrada na escola como lugar da infância para além das divisões de classes socioeconômicas ou das relações entre Estado e Igreja. A escola, porque passava a ser frequentada por muitos, repensa suas finalidades; porque baseada em ampla pesquisa científica, sobretudo ligada à psicologia, repensa seus métodos; porque comprometida com um modelo liberal e democrático de sociedade, repensa as relações de poder em sala de aula.

Certamente as inovações pedagógicas não se dão de maneira abrupta, nem mesmo são realizadas sem resultar em contradições. Tampouco as ideias veiculadas em textos retratam fielmente as práticas através das quais a realidade educacional se

\footnotetext{
${ }^{10}$ Segundo Canclini $(2015$, p. 68$)$, as taxas de analfabetismo evoluem da seguinte maneira no período: $1890,84 \% ; 1920,75 \%$; 1940, 57\%. De acordo com Monarcha (2009, p.84), nos primeiros anos do século XX apenas $3 \%$ da população brasileira - homens alfabetizados com mais de 21 anos - poderiam ter direito ao voto.
} 
constitui no cotidiano escolar. Portanto, precisamos que o objetivo desta pesquisa é elucidar as ideias e os indícios de práticas pedagógicas que circulavam nas fontes selecionadas, sem a pretensão de abranger as várias dimensões possíveis na compreensão do movimento pedagógico em questão.

As ondas modernizadoras apontadas por Canclini (2015), e aqui citadas anteriormente, dizem respeito às especificidades da América Latina em um processo cultural generalizado no mundo ocidental, do qual a escolarização da infância é uma característica central. Apesar da efetiva difusão da instituição, sua universalidade não se realiza de maneira direta e sem escapar aos modelos. Em relação ao ideário escolanovista, por ter sido extensamente baseado em estudos de psicologia, tinha a pretensão de universalidade apoiada na objetividade científica (MONARCHA, 2009). No entanto, como adverte Nóvoa (1998), a pedagogia não fica sujeita facilmente a uma ou duas ciências. Segundo o autor, quando trata de Educação Comparada, esta se funda precisamente no conflito e na contradição permanentes entre diversas correntes acadêmicas, políticas, econômicas e culturais.

Para responder às perguntas que guiam a investigação, além de levar em conta aspectos da Educação Comparada, porque consideramos um cenário de circulação de ideias pedagógicas, lidamos especialmente com aspectos específicos dos trabalhos historiográficos.

Para a leitura das fontes delimitadas - as revistas pedagógicas Progressive Education, La Nouvelle Éducation e Revista Brasileira de Estudos Pedagógicos, em seus textos que tratem de processos criativos e/ou ensino de música e artes - tomamos como fundamentais alguns pontos. Primeiro, partimos do pensamento do trabalho historiográfico em duas dimensões de Schorke, citado por Chartier (1990):

O historiador procura localizar e interpretar temporalmente o artefato num campo em que se intersectam duas linhas. Uma linha é vertical, ou diacrônica, pela qual ele estabelece a relação de um texto ou de um sistema de pensamento com as manifestações anteriores no mesmo ramo de atividade cultural (pintura, política, etc.). A outra é horizontal, ou sincrônica; através dela, determina a relação do conteúdo do objeto intelectual com o que vai surgindo ao mesmo tempo noutros ramos ou aspectos da cultura (SCHORKE in CHARTIER, 1990, p. 63-64)

Acrescento ao estabelecimento de relações com manifestações anteriores como necessidade para a compreensão de nosso objeto em um âmbito diacrônico, a 
importância de não desconsiderar seus desdobramentos posteriores para uma análise consciente. Segue um pequeno exemplo neste sentido: ao mesmo tempo em que, ao analisar a proposta orffiana no que diz respeito às práticas criativas, percebemos seus limites quando comparada às propostas que se desenvolvem posteriormente e já estabelecidas sobre ideias mais abrangentes de música e infância, também podemos reconhecer as novidades que possibilita quando comparada à área tal como se apresentava até aquele momento.

Em relação à dimensão sincrônica, um exemplo claro é a impossibilidade de interpretar o projeto de educação musical de $\mathrm{H}$. Villa-Lobos sem levar em consideração o ideário nacionalista que dominava a cultura de uma maneira geral, além das condições políticas em que se assentavam as relações de poder que permitiram sua efetivação. Não apenas a consolidação da proposta como política pública dependeu deste cenário, mas mesmo suas características fazem referência a ele, como, por exemplo, o forte apelo cívico e nacionalista na seleção de repertório.

Encarar um objeto através das duas dimensões definidas por Schorke nos auxilia em dois desafios próprios do trabalho em história, a saber, o esforço para evitar a leitura anacrônica das fontes e realizar uma contextualização adequada. A presente pesquisa, por aproximar-se do domínio da história das ideias, lida ainda com a necessidade de entendimento do quadro onde as ideias são produzidas e veiculadas. Assim, a figura do produtor de ideias não deve ser negligenciada, visto que mesmo a posição de intelectual em meio à determinada configuração social revela-se como fator a ser estudado em sua historicidade (DOSSE, 2003). Em nosso caso, para constituir um retrato da educação musical no ideário escolanovista, não é possível negligenciar a autoria dos textos que nos competem e as relações que se estabeleciam entre estes autores, os demais autores das revistas e os artistas em atividade no período. Sobre as redes que se estabelecem na produção e na circulação de ideias, Barros afirma:

Não menos importante para o historiador das ideias é perceber e dar a perceber a rede dentro da qual está inserido determinado autor "produtor de ideias" - investigando dentro desta rede tanto as influências que o autor recebe como a recepção de suas ideias pelos diversos contemporâneos. Importante examinar, ainda, os diálogos do "produtor de ideias" com toda uma rede intertextual que remonta à tradição dentro da qual seu pensamento se inscreve ou que, também de modo contrário, o contrasta com as tradições contra as quais as ideias do autor estabelecem uma relação de ruptura (BARROS, 2007, p. 208) 
$\mathrm{Na}$ análise dessas redes, buscamos elucidar principalmente as ideias de música e de infância, pelo entendimento de que essas são as determinantes centrais para as características das propostas de educação musical, conscientes, contudo, de que esta tarefa não resulta em um retrato livre de contradições. Como afirma Brito (2007), as relações que os seres humanos estabelecem com os sons e os silêncios, caracterizando-os como música, são contextuais e podem coexistir, assim como também estão sujeitas às demais relações da cultura.

Temos ciência de que ideias de música emergem, se estabelecem e se transformam continuamente, em diferentes escalas de tempo. Para cada pessoa, para um grupo, para um período histórico. Que são possibilidades marcadas, no entanto, pela força de estabilidades que chegam a desconsiderar as ideias de música para dar lugar a uma única ideia de música (BRITO, 2007, p. 14)

Porque contextuais, estão sempre imbricadas em relações que se conectam às demais configurações de uma sociedade em determinado período. Aqui, nos interessa especificamente as ideias de música quando relacionadas ao ideário escolanovista. Este ideário, por sua vez, carrega uma série de representações da cultura de uma maneira geral, além da música, centro de interesse em nosso caso particular.

Aliado ao entendimento do lugar da música nos movimentos da Escola Nova, concerne ao presente trabalho o entendimento da situação da infância em meio à produção intelectual, aos debates públicos e às experiências pedagógicas aqui focalizadas. Neste sentido, parece oportuno considerar a afirmação de Sarmento, ao tratar das imagens sociais da infância a partir de James, Jenks e Prout,

As diversas imagens sociais da infância frequentemente se sobrepõem e confundem no mesmo plano de interpretação prática dos mundos das crianças e na prescrição de comportamentos e de normas de atuação. Não são compartimentos estanques, mas dispositivos de interpretação que se revela, finalmente, no plano da justificação da ação dos adultos com as crianças (SARMENTO, 2007, p. 33)

Assim, tampouco as imagens da infância podem ser tomadas como passíveis de simples entendimento, mas dependem, em sua dimensão sociológica, da compreensão das relações que se estabelecem entre gerações, principalmente quando 
se trata de projetos educacionais. A própria instituição escolar se funda na relação geracional para a organização social e para a manutenção da cultura. Esta característica é um dos pontos de conflito na revisão da instituição pelo ideário renovador do início do século XX e, ainda mais fortemente, é central em produções intelectuais posteriores.

No trabalho direto com as fontes, buscou-se, em um primeiro momento, (a) compreender aspectos gerais das revistas e das associações que as produziam, através da observação de como as publicações se organizavam em seções, como reportavam as atividades como congressos, assembleias, grupos de estudos, etc. Em seguida, (b) a atenção foi direcionada ao conteúdo próprio ao campo da educação musical.

Para o trabalho específico em educação musical, foram tomados os textos em que o domínio é tratado como tema central ou secundário, bem como menções em anúncios e relatos de atividades das associações. Buscou-se, com a leitura, identificar características das práticas e dos discursos veiculados nas revistas. A leitura foi guiada pela identificação das seguintes categorias: (a) autoras e autores, (b) pessoas, grupos e instituições mencionadas, (c) temas tratados e (d) publicações indicadas.

A leitura e a análise das revistas e dos materiais nelas referenciados nos autorizam a elaborar, então, o que constitui nossa contribuição original para o campo, a saber: um retrato da educação musical em meio a movimentos escolanovistas. Segue-se, assim, a confirmação da tese de que existiram ideias e práticas em educação musical próprias ao ideário e às práticas pedagógicas renovadoras nos locais e décadas que são objeto de nossa pesquisa. Tais ideias e práticas circularam entre os cenários aqui focalizados e apresentavam, à sua maneira, a participação e a criação das crianças como fatores fundamentais nos processos de ensino e aprendizagem. 


\section{Capítulo 2 - Educação musical e renovação escolar nos Estados Unidos}

\subsection{Progressive Education}

A associação Progressive Education é fundada no ano de 1919 em meio a um cenário de discussões e mudanças no campo da educação escolar estadunidense. $\mathrm{O}$ período que envolve a segunda metade do século XIX e as primeiras décadas do século XX é um momento histórico em que diversos aspectos da vida social, inclusive a educação, ganham cada vez mais caráter nacional e centralizado. Segundo Alix (2017), a fundação da associação marca o ponto de partida de uma nova fase do período $^{11}$, no qual as discussões e tentativas de reformas passam a encontrar propostas mais efetivas de renovação das práticas pedagógicas. No cenário de reformas legislativas e propostas de novas maneiras de ensinar e organizar o meio escolar, os objetivos da educação se transformam na sociedade estadunidense. Em suas palavras:

No espaço de algumas décadas, a Era Progressista e a Escola Progressista que dela se origina, modificam radicalmente os objetivos do sistema educacional do país. Os ideais de uma cultura escolar focada na exigência acadêmica, no ensino de disciplinas e na figura do mestre [...], são substituídos pelos de uma educação socialmente eficaz, centrada na criança, na necessidade de respeitar suas especificidades e de formar os futuros cidadãos para a democracia (ALIX, 2017, p. 18)

Contrastando com o período anterior, centrado na proposição de reformas e demais políticas públicas - logo, pautado por discussões e ações em meios oficiais -, a fundação da associação em 1919 aparece como esforço de organização de outros agentes em torno das discussões e ações visando a transformação da realidade escolar

\footnotetext{
${ }^{11}$ Existem diversas periodizações concernentes ao período denominado Era Progressista ou ao que se chama Educação Progressista nos Estados Unidos. Visto que o presente trabalho se concentra no período entre guerras, escapa aos nossos objetivos o estabelecimento de limites rigorosos para esses períodos. Contudo, a década de 1870 nos parece expressiva na medida em que é o momento em que Francis Wayland Parker parte para visitar escolas em diversos países europeus e, de volta aos Estados Unidos, desenvolve suas experimentações pedagógicas (WALLACE, 1995), cuja importância destacamos mais a frente. É também nesta década, mais especificamente em 1876, que se inicia o movimento pelo ensino manual, industrial e profissional - manual, industrial and vocational training movement - o qual Alix (2017) considera determinante para todo o cenário de contestações posteriores sobre a didática e os fins da educação estadunidense. No que concerne ao fim do período, a década de 1950 é expressiva pela dissolução da associação Progressive Education e pelo fim da circulação da revista de mesmo nome.
} 
no país. Essa não é a primeira organização a envolver intelectuais, educadores e demais agentes sociais no debate público sobre a escolarização e suas mudanças, mas tem a particularidade de congregar aqueles com inclinação progressista. Ainda que apresente algumas divergências em aspectos como fundamentação teórica ou orientações didáticas, a associação reúne pessoas que militam em diversas áreas pelos novos objetivos da educação indicados na citação acima.

O uso do termo Progressive Education, no entanto, data de muito antes da fundação da entidade assim nomeada. Ainda no contexto da associação, que existiu até 1955, Palm (1940) empreendeu um exame das origens da Progressive Education. O primeiro uso do termo apontado por ele data ainda do início do século XIX, na obra de Albertine-Adrienne Necker de Sausurre intitulada L'Éducation Progressive. O primeiro volume, publicado originalmente em língua francesa em 1828, teve sua primeira tradução em Boston no ano de 1835. Ao fazer referência a tal obra, Palm (1940) a aproxima tanto da produção anterior, nomeadamente àquela de Rousseau, quanto da Progressive Education estadunidense do início do século XX. O autor admite que não há acordo total e inconteste entre as obras dos dois suíços, tampouco entre esses e as características do movimento do qual é contemporâneo, no entanto, afirma que as "similaridades são mais evidentes que as diferenças" (PALM, 1940, p. 444).

A Éducation Progressive de Necker de Saussure foi traduzida nos Estados Unidos como Progressive Education no início do século XIX e o movimento de quase um século depois, sem fazer referência expressa à obra da autora suíça, adota também tal termo. Para Raillon (2004), ligar o movimento estadunidense à Necker de Sausurre é descabido. Ele afirma que, além de não ser possível relacionar diretamente a obra da autora às atividades de quase um século mais tarde, existe uma imperfeição na tradução do termo. Quando fala da tradução francesa do título da associação, Raillon (2004) afirma que o correto seria Éducation Progressiste de acordo com as características do movimento. A inconsistência das traduções, tanto em inglês quanto em francês ${ }^{12}$, é apenas um detalhe na construção do argumento do autor em sua tentativa de desconstruir uma visão por demais generalizante da história dos

\footnotetext{
${ }^{12}$ A confusão gerada em tais traduções expressa-se, em português, na não equivalência entre os termos "progressiva" e "progressista". Aqui, valemo-nos do termo "progressista" de acordo com as características do movimento pedagógico, que se pautava em ideias relacionadas à transformação e à modernização da sociedade daquele momento. O adjetivo "progressiva", uma das traduções possíveis da palavra de língua inglesa, não caberia em tal contexto.
} 
movimentos de renovação escolar da primeira metade do século XX. Defendendo uma postura historiográfica mais cautelosa e detida sobre os desdobramentos específicos de tais movimentos, ele afirma que "enxergar a pedagogia nova em todo grande autor que tenha tratado de crianças e de educação no curso da história é o mesmo que diluí-la, destituí-la de sua originalidade, banalizá-la e destruí-la" (RAILLON, 2004, p. 320).

Em trecho comprometido com o mapeamento do uso do termo no cenário específico dos Estados Unidos, Palm (1940) aponta ocorrências dele em publicações da década de 1910, deixando claro que nem sempre estão estritamente ligados à associação que se forma em 1919. Alix (2017), por sua vez, aponta as décadas de 1870 e 1880 como os momentos em que o termo começa a ser usado em jornais e revistas pedagógicas. Acreditando ser arbitrária qualquer tentativa de apontamento da origem exata tanto do termo quanto do movimento, não nos comprometemos aqui a aceitar uma data específica como marco de origem. Tampouco tomamos a fundação da associação e, um pouco mais tarde, de sua revista, como uma ocorrência desprovida de conjuntura ou ligação a acontecimentos prévios. Assim, interessa-nos aqui o cenário onde foi possível seu surgimento e seu posterior desenvolvimento.

Ao tomarmos a circulação internacional e a experimentação pedagógica como características centrais do movimento, Francis Wayland Parker (1837 - 1902), a quem Dewey atribui a "paternidade" da Progressive Education (ZILVERSMIT, 1993; WALLACE, 1995), aparece como figura de importância contundente na virada do século. Segundo Wallace (1995), Parker estabeleceu um padrão, seguido posteriormente por outros educadores progressistas, de viajar para visitar escolas com o intuito de conhecer novas propostas e fundamentar as suas próprias. Na década de 1870, o educador estadunidense passou dois anos e meio visitando escolas europeias, sobretudo alemãs. Essa atitude foi retomada por educadores de protagonismo no movimento de décadas a frente, como Carlton Washburne, que visitou doze escolas experimentais europeias entre os anos de 1925 e 1926, em viagem cuja documentação deu origem a publicações ${ }^{13}$; William Heard Kilpatrick, que visitou escolas e universidades entre os anos de 1926 e 1927, passando por países como China, Japão, Inglaterra, Alemanha, Polônia e a então União Soviética; e John Dewey, que também

\footnotetext{
13 "Uma das mais documentadas e largamente difundida dessas viagens foi a de Carleton Washburn em meados dos anos 1920. A viagem foi descrita e interpretada por Washburn (juntamente com Myron Stearns) em uma série de relatórios publicados na revista popular "Collier's Weekly"; os quais foram, posteriormente, publicados em New School in the Old World [1926]" (WALLACE, 1995, p. 136)
} 
visitou países de diferentes continentes publicando artigos sobre suas impressões no âmbito educacional, dentre os quais, aqueles dedicados às observações das transformações sofridas pela Rússia Soviética acabaram por tomar forma de livro publicado em $1928^{14}$. Em 1914, Dewey também já havia viajado à Suíça e estabelecido contato com Adolphe Ferrière, cujo empenho em conectar educadores na Europa datava do final do século XIX, e sua obra já começava a ser traduzida para o francês ${ }^{15}$.

A respeito da experimentação pedagógica, mais uma vez o pioneirismo de Francis Wayland Parker é notável. Após o período de visitação a escolas na Europa, Parker desenvolveu alguns trabalhos, dentre os quais se destacam suas atividades como superintendente em Quincy, Massachusetts, como formador de professores na Cook County Normal School e, em 1901, um ano antes de sua morte, como fundador da escola que existe até hoje em Chicago e leva seu nome ${ }^{16}$. Em seus experimentos, características da prática pedagógica progressista hoje amplamente difundidas como, por exemplo, a alfabetização através de materiais de leitura feitos pelas próprias crianças e aulas passeio como ponto de partida para estudos da natureza - já eram realidade (ZILVERSMIT, 1993).

Carlton Washburne teve sua formação já na infância ligada aos experimentos de Parker. Ele estudou na escola laboratório da Cook County Normal e, posteriormente, na Francis W. Parker School. Marion Washburne (1863 - 1944), mãe de Carlton, era ativa no movimento pedagógico, foi amiga pessoal de Parker e de Alice e John Dewey. Carlton cresceu imerso neste cenário, no qual acabou por atuar profissionalmente (ZILVERSMIT, 1993). Em Winnetka, Illinois, liderou um grande plano de educação progressista na rede pública entre os anos de 1919 e 1943 que tinha como principal característica a individualização do ensino (WALLACE, 1995). Ao lado de um sistema programado para o desenvolvimento individual de habilidades julgadas fundamentais para todas as crianças, as atividades em grupo apareciam como

\footnotetext{
14 "Essa obra [Impressions of Soviet Russia and the Revolutionary World] consistia na redação das impressões de John Dewey por ocasião de sua visita à Rússia Soviética junto com um grupo de educadores para conhecer os fundamentos da educação soviética. Essas impressões foram registradas em um conjunto de artigos publicados na revista New Republic em novembro e dezembro de 1928. A publicação registrou, também, um conjunto de visitas de Dewey realizadas na Alemanha, China, Japão, Sibéria, Turquia e México" (LUCENA; LUCENA, 2016, p. 8).

${ }^{15}$ A circulação internacional, seja de viajantes a visitarem escolas em países distintos, seja da profusão de material e de sua tradução, é intensificada especialmente após a Primeira Guerra Mundial. Segundo Nóvoa (1998), esse é um momento em que as considerações sobre educação ganham ares globais, o que virá a ser inconteste algumas décadas depois, após a Segunda Guerra Mundial.

${ }^{16}$ https://www.fwparker.org/page/about/history Acesso em 11 fev. 2019.
} 
espaço de desenvolvimento criativo e de socialização. Além do trabalho com as crianças, em 1932 o projeto passa a contar também com a formação de professores (ZILVERSMIT, 1993). Seu trabalho como superintendente da educação pública de Winnetka - Illinois, apesar de uma série de conflitos políticos ligados às transformações pelas quais a cidade passava e ao caráter democrático previsto para a gestão da rede (ZILVERSMIT, 1993), manteve-se por vários anos e destacou-se pela originalidade das suas proposições.

Há ainda diversos outros espaços de experimentação pedagógica, dentre os quais um de grande importância é a escola laboratório fundada por Alice e John Dewey na Universidade de Chicago em 1896. Alguns anos depois, o casal enfrenta atritos com outros profissionais da administração e retira-se da instituição. Em 1904, John Dewey assume o cargo de professor no Departamento de Filosofia e no Teachers College da Columbia University, onde se torna responsável pela disciplina de Filosofia da Educação. Nessa instituição encontra-se a Lincoln School, uma das escolas experimentais em evidência no início do século XX. A formação de professores na Columbia University é central não apenas para o movimento progressista nos Estados Unidos, mas também em âmbito internacional, visto que seus cursos regulares e de férias recebem educadores de todo o mundo.

A revista Progressive Education se insere neste cenário de experimentação pedagógica e circulação de ideias, cujos exemplos anteriores nos dão uma pequena, mas significativa amostra. A publicação consistiu em um espaço de divulgação de experiências e veiculação do discurso progressista em âmbito nacional e internacional. Inicialmente, como publicação da associação Progressive Education, fazia parte da construção e consolidação de uma rede estadunidense através da divulgação de projetos inovadores, ao mesmo tempo em que contava com traduções de artigos e notícias do exterior. A ligação com o cenário internacional se solidifica na década de 1930, com a filiação da associação à New Education Fellowship. Entre sua fundação e o ano de 1930, a associação passa de 86 a 7400 membros (RÖHRS, 1995), difundindo o ideário pedagógico progressista por publicações, programas de rádio e eventos como conferências, cursos e exposições. 
Fonte expressiva de tal cenário, a revista Progressive Education foi publicada pela associação homônima entre os anos de 1924 e 1957. Para compor o quadro da presente tese, o período selecionado vai de 1925 a 1944. Esta seleção considera a relevância do conteúdo para o trabalho em questão, bem como a disponibilidade do material $^{17}$.

Nos primeiros anos, a revista teve frequência trimestral, com exceção do ano de 1924, no qual apenas 3 números foram publicados. Em 1930, a frequência passa a ser mensal, exceto no verão, com uma média de 8 publicações por ano. A revista era composta principalmente por textos que tratavam de experiências pedagógicas nos Estados Unidos, mas também apresentava traduções que difundiam o trabalho de movimentos estrangeiros e escritos sobre temas educacionais que não estritamente ligados à prática pedagógica. Contava ainda com uma seção de resenhas e indicações bibliográficas para seus leitores, além de divulgação e relatórios de eventos, como assembleias, congressos, cursos, propagandas de produtos, etc.

Apresentamos aqui uma visão geral dos conteúdos da revista ligados ao campo da educação musical. Na medida em que nosso objetivo é observar e confirmar nossa hipótese - a importância dos processos criativos nos projetos de ensino de música quando em cenário escolanovista - nossa exposição não se pretende exaustiva. Antes, intentamos contribuir para a compreensão de como a educação musical mostra-se coerente com o ideário pedagógico em questão através dos conteúdos produzidos pela associação estadunidense.

\subsection{A educação musical na revista Progressive Education}

Para observar as ideias e práticas em educação musical veiculadas pela revista, consideramos textos de características diferentes, como artigos que abordam a área de maneira central ou secundária, informações sobre as atividades da associação e de outras organizações, resenhas e recomendações de livros, etc. Salientamos que as categorias aqui elencadas e seus conteúdos são resultado de uma leitura de material híbrido, o que implica em uma maior abertura para a identificação dos conteúdos, ao

\footnotetext{
${ }^{17}$ O primeiro número do primeiro volume (1924) não foi encontrado em nenhuma das numerosas instituições visitadas. A primeira indicação relevante em educação musical se encontra no número 4 do volume II, de 1925
} 
mesmo tempo em que nos coloca desafios de interpretação. Assim sendo, não temos por objetivo esgotar informações descritivas, pois o próprio material, em sua complexidade, não se adequa a tal aproximação. Ele nos serve como meio de verificação de nossa tese, a qual consiste na asserção da presença de projetos de educação musical em consonância com o ideário escolanovista, nos quais se conferia importância pioneira à promoção de processos criativos das crianças. Serve-nos, ainda, a compreender as diversas - e mesmo divergentes - configurações que a educação musical tomou quando imersa em tal ideário.

Especialmente nesta revista observamos algo particular, que não foi encontrado nas demais, a saber: a área da educação musical tematizada em anúncios publicitários. Também algo que se organiza de maneira específica nessa publicação, em seus últimos números de nossa periodização, é uma série de indicações de repertório para apreciação musical infantil apresentada por temas. Esses são alguns exemplos das particularidades dessa revista e da diversidade de materiais que constituem o quadro exposto a seguir.

\section{(a) Autoras e autores}

No que concerne aos materiais aos quais é possível atribuir autoria, foram identificadas 67 assinaturas diferentes, das quais sete são siglas. No entanto, o número total diminui para 66 com a atribuição de uma das siglas - S. N. C. - à Satis Narrona Coleman, autora que assina textos também por extenso e cuja relevância é tema sobre o qual nos deteremos mais adiante. Há ainda um texto sem assinatura, mas que, pelo seu conteúdo, pode ser atribuído a um grupo de professores não-identificados da Francis W. Parker School ${ }^{18}$.

Do total de 66 autores, apenas sete contribuem mais de uma vez para a revista. $\mathrm{Na}$ tabela a seguir, esses sete autores encontram-se listados de acordo com a quantidade de contribuições, em ordem decrescente. Apresentamos seus nomes como figuram na revista, bem como alguns aspectos de suas contribuições.

\begin{tabular}{|l|l|l|}
\hline Autor(a) & Número de contribuições & Detalhes \\
\hline
\end{tabular}

\footnotetext{
${ }^{18}$ ON teacher guidance and child initiative. Progressive Education, 1931, vol. VIII, p. 662 - 663.
} 


\begin{tabular}{|c|c|c|}
\hline Lorraine St. Amand & 7 & $\begin{array}{l}\text { Série de repertório sugerido } \\
\text { para apreciação, organizado em } \\
\text { listas temáticas, como Vamos } \\
\text { ouvir ópera (vol. XXI, jan.) e } \\
\text { Para as horas de descanso } \\
\text { (vol. XXI, fev.). Em nossa } \\
\text { periodização, as listas } \\
\text { encontram-se entre outubro de } \\
1943 \text { e maio de } 1944\end{array}$ \\
\hline Satis N. Coleman & 4 & $\begin{array}{l}\text { Dois artigos, dois textos } \\
\text { referentes a conferências } \\
\text { proferidas pela autora e uma } \\
\text { resenha }\end{array}$ \\
\hline $\begin{array}{l}\text { Thomas } \quad \text { Whitney } \\
\text { Surette }\end{array}$ & 3 & Dois artigos e uma resenha \\
\hline Edith Potter & 3 & $\begin{array}{l}\text { Um artigo, um texto referente a } \\
\text { conferência proferida pela } \\
\text { autora e uma resenha }\end{array}$ \\
\hline Ruth Doing & 3 & $\begin{array}{l}\text { Dois artigos e um texto } \\
\text { referente a conferência } \\
\text { proferida pela autora }\end{array}$ \\
\hline David Dushkin & 2 & $\begin{array}{l}\text { Um artigo e um texto referente } \\
\text { a conferência proferida pelo } \\
\text { autor }\end{array}$ \\
\hline Fletcher Collins Jr. & 2 & Dois artigos \\
\hline
\end{tabular}

Tabela 1 - Autoras e autores identificados na revista Progressive Educaiton

Por um lado, a grande quantidade total de assinaturas pode ser vista como expressão de um espaço democrático e aberto a diferentes vozes. Por outro lado, a análise do quadro acima também dá-nos a ver o protagonismo de algumas pessoas, sobretudo quando nos debruçamos sobre os conteúdos dos textos.

Observamos que a maior quantidade de contribuições é assinada por Lorraine St. Amand, o que pode ser compreendido pela natureza de suas publicações. De outubro de 1943 a maio de 1944, onde se encerra nossa periodização, a autora publica 
uma série de sete listas de indicação de repertório para escuta musical com crianças. As listas são, por vezes, temáticas, e não muito extensas, têm por volta de cinco obras acompanhadas de referências fonográficas e breve apresentação. Porque não apresentam claramente proposições didáticas, acreditamos que não sejam dedicadas exclusivamente a educadores, mas a adultos de uma maneira geral. A primeira publicação traz, além da lista de indicações para escuta - que, nesse caso, constitui-se de música tradicional de outros países, como China e Rússia, e de composições de temática infantil, como Pedro e o Lobo de S. Prokfiev e O Carnaval dos Animais de C. Saint Saens - , a seguinte mensagem:

Nem todas as crianças vão gostar de todas as gravações - e nem todo o tempo. Mas elas vão escutar boa música - e fazê-la também. A música deve ser uma parte de suas vidas. Leiam o livro de Satis Coleman, Your child's music, publicado pela companhia John Day (AMAND, 1943, p. 302, grifos no original)

Deixando as discussões acerca do que seria a "boa música" no cenário da Progressive Education para a seção concernente ao repertório que apresentamos mais adiante, atentamos para dois aspectos dessa citação. O primeiro, como mencionado acima, diz respeito ao caráter não diretivo em relação à didática. A escuta musical aqui é apresentada como algo que deve "fazer parte da vida", um hábito a ser incentivado, sem mais indicações de como isso deve ser feito junto às crianças. $\mathrm{O}$ segundo aspecto é a recomendação bibliográfica expressa ao final, o que nos leva à autora que mais contribuiu para a revista depois de Lorraine St. Amand - que, por sua vez, não apresenta outras produções para além da série de repertório, tampouco é citada ou indicada por outros.

A segunda autora que mais apresenta contribuições para a revista é Satis Coleman. Sua centralidade é inconteste em meio ao material analisado, mesmo que a quantidade de quatro contribuições possa parecer, em um primeiro momento, pouco expressiva. Seu nome aparece em outras categorias segundo as quais organizamos os conteúdos das revistas, como pessoas citadas - somando dez indicações - e recomendações bibliográficas - dentre as 57 obras encontradas como sugestão para leitura, dez são de sua autoria. Tamanha é a influência de seu trabalho no cenário e sua pertinência ao recorte de nosso estudo, que dedicamos uma seção da presente tese aos principais aspectos de sua proposta - a Creative Music - e aos desdobramentos ocorridos durante nossa periodização. Em relação à tabela apresentada acima, sua 
importância se confirma com a constatação de que quase a totalidade das produções ${ }^{19}$ de outros três autores que a seguem na lista tem relação direta com sua obra.

Thomas Whitney Surette, o terceiro autor da lista, assina dois artigos e uma resenha. Nos dois textos ${ }^{20}$ originais apresenta críticas ao trabalho de Coleman de maneira evidente, as quais abordamos na seção desta tese dedicada às propostas da educadora. Entretanto, o autor não limita sua escrita às contestações ao trabalho de Coleman, sendo também propositivo. Seu aporte à área está ligado principalmente à defesa do ensino de música vocal e da ênfase em repertório de concerto e folclórico. Neste âmbito, mais do que apresentar proposições didáticas e curriculares, ele editou e publicou compilações de repertório para uso educacional ${ }^{21}$.

Surette atuava sobretudo na formação de professores, proferindo conferências sobre ensino de música pelos Estados Unidos e pela Europa. De 1915 a 1939, dirigiu a Concord Summer School of Music, em Concord - Massachusetts, onde dava cursos para educadores. Também na formação de professores enfatizava a importância da seleção de repertório, nomeando como boas referências compositores desde a renascença até a música de seu tempo. O valor que atribui ao repertório pode ser lido como uma ênfase na educação como transmissão de um legado cultural, o que, em discursos não muito moderados, se volta contra a abertura defendida por Coleman para as composições das próprias crianças.

Edith Potter e David Dushkin, por sua vez, escrevem de maneira claramente alinhada às ideias de Satis Coleman. Mesmo que em seu primeiro texto ${ }^{22}$ Potter

${ }^{19}$ A totalidade de suas produções na revista Progressive Education e em nossa periodização. Certamente, estes autores produziram diversos materiais em outros veículos, no entanto, atentamos aqui para a presença de Coleman como referência central na revista.

${ }^{20}$ SURETTE, Thomas Whitney. "A general view of music education for children". In HARTMAN, Gertrude; SHUMAKER, Ann (org.). Creative expression: the development of children in Art, Music, Literature and Dramatics. New York: The John Day Company, 1932, p. 69 - 74. Esse texto foi originalmente publicado em 1927, em número da revista especialmente dedicado à educação musical. SURETTE, Thomas Whitney. "Music teaching in schools". Progressive Education, 1930, vol. VII (3), p. $107-114$.

${ }^{21}$ Dentre as recomendações de materiais identificadas na revista Progressive Education, consta uma resenha de um volume de sua série de compilação de repertório folclórico intitulada Songs from many lands (CHRISTIANSON, 1937). Além de ser fonte de material para o ensino de canto, o livro é apresentado como uma boa leitura para pais e mães, pois aborda temas como a iniciação musical de crianças no ensino de instrumento, a formação do gosto e a relação entre infância e as novas tecnologias para escuta de música gravada. Ao lado de demais professores de sua escola, Thomas Surette editou diversos materiais de educação musical, empreendimento intitulado The Concord Series of educational music and Books on Musical Pedagogy. Parte substancial de sua produção e de arquivo referente ao seu trabalho encontra-se na Concord Library. Cf. https://concordlibrary.org/specialcollections/fin aids/surette Acesso em 14 fev. 2019.

${ }^{22}$ POTTER, Edith. "The development of musical consciousness in the young child". In HARTMAN, Gertrude; SHUMAKER, Ann (org.). Creative expression: the development of children in Art, Music, 
agradeça a Surette pelo trabalho de organização de melodias folclóricas, já atribui grande importância às criações das crianças, desde os primeiros anos de aprendizado. Sua produção resultante de uma conferência ${ }^{23}$ trata da construção de instrumentos e do uso destes em projetos multidisciplinares na Avery Coonley School of Downers Grove, Illinois. Neste texto ela não apenas faz referência direta à Coleman, como a própria publicação deriva de participação em sessão de conferências presidida pela educadora. A resenha ${ }^{24}$ que completa sua contribuição para a revista diz respeito ao livro A children's symphony ${ }^{25}$, obra onde Coleman trata de seus experimentos em educação musical como professora da Lincoln School of Teachers College, da Columbia University. A resenha de Potter é de apreciação positiva tanto do livro quanto da ação pedagógica ali retratada. Em suas palavras: "Sente-se que muito do sucesso desse experimento é devido ao entendimento raro de Coleman em ambos os assuntos: música e crianças; sua infinita paciência e seu amplo conhecimento da herança musical de todos os povos” (POTTER, 1932, p. 528).

Uma das contribuições assinadas por David Dushkin também é resultado da conferência presidida por Coleman ${ }^{26}$. Sucintamente e fazendo referência expressa à educadora, Dushkin apresenta aspectos de seu trabalho nas escolas públicas de Glencoe, Illinois, como a ênfase na construção de instrumentos e da prática da composição individual e em grupo desde o início do curso. Esses e outros aspectos de seu trabalho ganham exposição mais minuciosa em artigo ${ }^{27}$ posterior, produzido especificamente para publicação. Neste segundo artigo, de 1933, o educador apresenta sua trajetória desde um projeto realizado em 1928 com crianças desmotivadas em Chicago, junto à Chicago Association for Child Study and Parent Education, onde começou a trabalhar com princípios da Creative Music. Entre 1928 e 1930, passa pelas escolas públicas de Glencoe e de Winnetka, pela Chicago Latin School for Boys, além de manter aulas em grupos privados. Acreditando não ser possível assegurar a qualidade de suas atividades com tamanha carga de trabalho, decide se dedicar apenas

Literature and Dramatics. New York: The John Day Company, 1932, p. 116 - 124. Esse texto foi originalmente publicado em 1927, em número da revista especialmente dedicado à educação musical.

${ }^{23}$ POTTER, Edith. "Values in the use of instruments in school projects". Progressive Education, 1931, vol. VIII, p. $345-346$.

${ }^{24}$ POTTER, Edith. "A children's symphony" (resenha). Progressive Education, 1932, vol. IX, p. 527.

${ }^{25}$ Tratamos do conteúdo deste livro na seção dedicada ao trabalho da autora.

${ }^{26}$ DUSHKIN, David. "Some experiments in music: the Glencoe Public Schools". Progressive Education, 1931, vol. VIII, p. 346 - 348.

${ }^{27}$ DUSHKIN, David. "An experiment in music education". Progressive Education, 1933, vol. XX, p. $144-149$. 
às escolas de Glencoe no ano de 1930 - 1931. No outono de 1931, ele e sua esposa Dorothy Dushkin, musicista que conheceu nos cursos de Nadia Boulanger em Paris abrem a School of the Musical Arts and Crafts, hoje Music Institute of Chicago ${ }^{28}$. David Dushkin apresenta seu trabalho sempre movido por uma postura experimental, o que fica evidente na citação a seguir:

[...] Eu não quero que ninguém considere minha técnica e filosofia educacional como algo estático ou definitivamente decidido. Ao contrário, em um ou dois anos eu provavelmente vou me contradizer em alguns assuntos, assim como meus caros amigos me contradizem hoje, sem necessariamente chegar às mesmas conclusões que eles (DUSHKIN, 1933, p. 149)

Ruth Doing, por sua vez, está menos ligada aos assuntos abordados pelos demais autores. Suas contribuições ${ }^{29}$ tendem a tratar a Rítmica como disciplina específica, desvencilhando-se de um papel de subárea da educação musical e aproximando-se mais da dança. Por esse motivo e de acordo com nosso foco na presente tese - as práticas criativas no ensino de música -, optamos por não nos debruçarmos sobre seu trabalho.

Fletcher Collins Jr., o último autor de nossa lista, contribui com dois artigos ${ }^{30}$. Em ambos os textos, Collins Jr. trata de repertório, mais especificamente, de canções folclóricas. $\mathrm{O}$ autor argumenta pela necessidade de uma educação musical que se valha de repertório nacional, e não apenas europeu. Segundo Collins Jr. (1938), visto que a industrialização e a urbanização transformam os modos de vida e, neste novo cenário, as famílias não constituem mais o espaço no qual ocorre a transmissão deste repertório, caberia à escola preservá-lo e ensiná-lo às novas gerações.

Os conteúdos das contribuições dos demais autores identificados - aqueles que foram publicados apenas uma vez pela revista -, incorporam-se aos trabalhos destes supracitados nas seções a seguir. Referências às suas trajetórias, instituições das quais faziam parte e outros dados serão feitas de acordo com sua pertinência em

\footnotetext{
${ }^{28} \mathrm{https} / / /$ www.musicinst.org/mission-history-0 Acesso em 14 de fev. 2019.

29 DOING, Ruth. "Rhythmics". In HARTMAN, Gertrude; SHUMAKER, Ann (org.). Creative expression: the development of children in Art, Music, Literature and Dramatics. New York: The John Day Company, 1932, p. 98 - 102. Esse texto foi originalmente publicado em 1927, em número da revista especialmente dedicado à educação musical.

DOING, Ruth. "The Gardner-Doing Camp". Progressive Education, 1928, vol. V, p. 169 - 170.

DOING, Ruth. "Rhythm and the dance in child development". Progressive Education, 1932, vol. IX, p. $314-316$.

${ }^{30}$ COLLINS Jr., Fletcher. "Cultural resources in Rural America". Progressive Education, 1938, vol. XV, p. $147-151$.

COLLINS Jr., Fletcher. "The songs of the people”. Progressive Education, 1942, vol. XIX, p. 12 - 14.
} 
relação às categorias que seguem em nossa exposição. Acrescentamos que o protagonismo de Satis Coleman nos materiais analisados não é aqui considerado somente em razão de sua presença como segunda autora mais assídua ou influência evidente para os demais agentes. Em nossa tese, o trabalho de Coleman ocupa lugar privilegiado sobretudo porque confirma a hipótese de que o cenário progressista contou com projetos de educação musical nos quais as práticas criativas e a participação das crianças eram tomados como fatores fundamentais.

\section{(b) Temas}

A identificação dos temas referentes à educação musical em discussões, relatos, resenhas e anúncios da revista Progressive Education se deu no decorrer da leitura do material selecionado. Mesmo que o trabalho com as fontes buscasse a confirmação de nossa hipótese sobre a presença de estímulos criativos, nenhum tema foi definido de antemão, sendo compilados na medida em que apareciam nos textos.

Apresentamos a seguir os temas de acordo com a frequência com que foram identificados, em ordem decrescente ${ }^{31}$. Em seguida, tratamos daqueles mais recorrentes, com especial atenção aos que estão estreitamente ligados à nossa tese.

\begin{tabular}{|l|l|l|}
\hline & Tema & Quantidade de ocorrências \\
\hline 1 & Criação & 48 \\
\hline 2 & Folclore/ multiculturalismo & 35 \\
\hline 3 & Escuta/apreciação & 32 \\
\hline 4 & Projetos/ interdisciplinaridade & 32 \\
\hline 5 & Repertório & 30 \\
\hline 6 & Construção de instrumentos & 22 \\
\hline
\end{tabular}

\footnotetext{
${ }^{31}$ Em um primeiro momento, foram identificados 44 temas, dentre os quais sete têm apenas duas ocorrências e, outros sete, apenas uma. Visto que nossa periodização cobre 19 anos de publicação da revista, acreditamos não gozarem de incontestável relevância os temas tão escassamente abordados. Consideramos, então, apenas os temas identificados no mínimo três vezes, o que nos leva a um total de 30 assuntos, dos quais apenas um terço aparece 10 vezes ou mais. Esse quadro geral nos permite constatar de maneira panorâmica o que tinha algum espaço - mesmo que breve - na revista, ao mesmo tempo em que atesta a importância dos assuntos mais recorrentes.
} 


\begin{tabular}{|c|c|c|}
\hline 7 & Motivação & 18 \\
\hline 8 & Novas tecnologias & 17 \\
\hline 9 & Ambiente doméstico/ familiar & 15 \\
\hline 10 & Música e sociedade & 10 \\
\hline 11 & Currículo & 10 \\
\hline 12 & Formação de professores & 9 \\
\hline 13 & $\begin{array}{l}\text { Experiências musicais anteriores ao contato com a } \\
\text { notação }\end{array}$ & 8 \\
\hline 14 & Indicações metodológicas & 8 \\
\hline 15 & Indústria cultural & 8 \\
\hline 16 & $\begin{array}{l}\text { Música está presente, mas não são apresentados } \\
\text { detalhes }\end{array}$ & 7 \\
\hline 17 & Desenvolvimento musical por estágios & 7 \\
\hline 18 & Defesa da educação musical & 6 \\
\hline 19 & Educação vocal X instrumental & 5 \\
\hline 20 & Cooperação & 5 \\
\hline 21 & Diferenças entre educador musical e músico & 4 \\
\hline 22 & Objetos como instrumentos & 4 \\
\hline 23 & Programas de rádio & 4 \\
\hline 24 & Educação do gosto e do julgamento & 4 \\
\hline 25 & Jogos como atividades pedagógicas & 3 \\
\hline 26 & Notação numérica & 3 \\
\hline 27 & Festival musical & 3 \\
\hline 28 & Espaços de exploração musical & 3 \\
\hline 29 & Religiosidade & 3 \\
\hline 30 & Competição (sempre visão negativa) & 3 \\
\hline
\end{tabular}

Tabela 2 - Temas identificados na revista Progressive Education relativos à educação musical 


\section{Criação musical}

A criação, assunto priorizado em nossa tese, ocupa espaço evidente nas publicações selecionadas. Sua recorrência é a mais volumosa, somando 48 identificações, e se dá de diversas maneiras. Consideramos aqui todas as discussões envolvendo o tema de forma específica ou secundária, bem como as indicações de existência de práticas pedagógicas que o realizavam. Com vistas a compreendê-lo em sua amplitude, tomamos o tema como reunião de registros que aludem à composição, tanto de canções quanto instrumental, e à improvisação. Há ainda indicações menos objetivas do que as que tratam explicitamente de atividades de composição e improvisação, as quais consideramos na medida em que configuravam espaços de discussão sobre o que estava sendo compreendido por "criativo" e apontam para a falta de consenso do cenário. Pela grande profusão do assunto, dedicamo-nos a comentar suas diferentes abordagens conscientes da impossibilidade de exauri-lo.

A importância dada às práticas criativas é clara desde os primeiros anos de nossa periodização e não se mostra apenas na área de educação musical. Em 1932, um livro é publicado reunindo números especiais da revista Progressive Education de anos anteriores. Tratava-se de uma série dedicada às áreas artísticas por meio de dossiês específicos ${ }^{32}$, dentre os quais o do ano de 1927 foi dedicado à educação musical. Na introdução à compilação de 1932, lemos que

Em razão da ênfase exclusiva nos modos de expressão próprios à criança através de todas as artes criativas, e em oposição aos modelos de acabamento e perfeição dos adultos, esses números se tornaram uma fonte de referência valiosa em escolas, bibliotecas e instituições de formação de professores (SHUMAKER, 1932, p. 5)

Esse é um primeiro indício de que, em meio a um cenário de reconsideração didática, hierárquica e ética entre gerações na instituição escolar, não apenas os métodos estavam sendo revistos, mas também existia uma reavaliação do julgamento dos resultados oriundos dos processos criativos das crianças. Como ficará evidente em outras passagens dos materiais analisados, existiu discrepância nessa reavaliação

\footnotetext{
${ }^{32}$ Artes visuais em 1926, Música em 1927, Literatura em 1928 e Teatro em 1931.
} 
estética entre as diferentes linguagens $\operatorname{artísticas~}^{33}$, no entanto, parece-nos digno de apontamento o fato de que a área de educação musical apareça contemplada em projeto que é introduzido com tal diferenciação.

No capítulo dedicado à música - Creative Expression Through Music - , encontram-se 12 artigos e uma seleção de indicações bibliográficas. Dentre os artigos, 11 tratam de criação de alguma maneira. Das publicações sugeridas, 10 trazem a temática em seus títulos, das quais cinco são de autoria de Satis Coleman, quatro são publicações de Francis W. Parker School ${ }^{34}$ e uma provém da escola laboratório da Universidade de Chicago. Portanto, a importância do assunto é inconteste neste momento, mesmo que com algumas dissonâncias.

Encontram-se nessa compilação, como já abordado na seção precedente onde tratamos das autoras e dos autores publicados pela revista e também em seção dedicada ao trabalho de Coleman, tensões em relação ao papel da criação na educação musical de crianças. Entretanto, de uma maneira geral - e em conformidade com o título da publicação - os autores defendem a abertura à criação no ensino de música, mesmo que isso se mostre em diferentes nuances. É notável que os discursos tendam a ser menos extremos quando acompanhados de relatos de experiência pedagógica, congregando as ideias progressistas e as limitações da prática educacional.

Como relatos de tais práticas, temos, sobretudo, exemplos de composições de canções (DAVIS, 1932; DYKEMA, 1932; GOODRICH, 1932; POTTER, 1932; STEELE; LILLARD, 1932). As composições estavam, muitas vezes, ligadas a um projeto como uma peça de teatro ou um festival, onde aparecem como uma das etapas de um processo criativo muito maior, incluindo outras linguagens e integradas a pesquisas. Os textos de Dykema (1932) e Goodrich (1932) são exemplares neste aspecto. No texto de Potter (1932), a autora afirma que, naquele momento, uma de suas turmas trabalhava em canções para uma pequena ópera e que duas turmas

\footnotetext{
${ }^{33}$ Podemos afirmar, por exemplo, que até hoje as artes visuais gozam de maior abertura do que a música quando se trata da valoração dos produtos criativos das crianças. Neste sentido, o trabalho de Brito (2003) é exemplar quando trata das produções musicais na infância como garatujas sonoras.

${ }^{34}$ Apresentamos aqui as referências tais quais aparecem no dossiê. As obras de Coleman são apresentadas na seção específica.

CANFIELD, Julia. Original compositions. Francis Parker Year Book, vol. I. F. W. Parker School, Chicago.

CORNISH, Luella. Creative effort in melody. Francis Parker Year Book, vol. VIII.

GOODRICH, Helen. Creative effort in melody. Francis Parker Year Book, vol. VIII.

GREENBAUM, Sarah. Creative effort in the morning exercise. Francis Parker Year Book, vol. VIII.

KERN, M. R. Song composition. Elementary school record, n.2, Elementary music teaching in the Laboratory School. Elementary School Teacher, September, 1903.
} 
haviam produzido livros com suas composições acompanhadas de ilustrações para presentear as famílias. Steele e Lillard (1932) expõem, em seu texto, processos de criação ligados a projetos em outras disciplinas, como um grupo que estudava a China nas aulas de geografia e passou a fazer improvisos e compor canções em instrumentos chineses.

As composições aparecem tanto como produções individuais quanto como resultado de trabalhos em grupo. Ao abordar de maneira descritiva o processo composicional das crianças com quem trabalhava, Goodrich (1932) nos mostra como transcorriam processos que congregavam a ação individual e a participação da turma. Em um primeiro momento, cada criança compunha suas melodias sozinha, as quais a professora ajudava a transcrever e, caso solicitado e posteriormente aprovado pela criança, adicionava um acompanhamento. Em seguida, as composições eram expostas na lousa para receber sugestões dos colegas, as quais poderiam ou não ser levadas em consideração por quem compôs. Assim, o processo criativo individual passa também pela mediação dos pares, o que seria positivo para todos e em vários aspectos, pois a iniciativa de sugerir mudanças na composição não poderia ser vaga ou incerta, e sim promover debates sobre as características e as possibilidades da canção ${ }^{35}$.

Em concordância com o trecho da introdução da compilação de artigos citado aqui anteriormente, onde se faz referência à existência de especificidades dos modos de expressão e de avaliação estética na infância quando comparados aos dos adultos, observamos ainda duas ocorrências interessantes. Tanto no texto de Davis (1932) quanto no texto de Potter (1932), encontramos uma consideração especial em se tratando da expressão criativa das crianças pequenas. Davis (1932), ao relatar as criações de canções em aula, atenta para o fato de que as crianças do ensino infantil e dos dois primeiros anos do que nomeamos ensino fundamental encontravam muito mais satisfação em improvisar do que em compor. De acordo com as experiências da educadora, o pensamento composicional se mostrava de fato profícuo para as crianças mais velhas, enquanto as pequenas criavam de maneira a não se preocuparem com a manutenção de suas produções. Potter (1932), por sua vez, atribui aos anos de ensino infantil e ingresso no fundamental o momento mais propício para o incentivo à originalidade, sobretudo se as crianças não estivessem muito expostas às ideias dos

\footnotetext{
${ }^{35} \mathrm{O}$ processo composicional assim descrito muito se assemelha à técnica do Texto Livre tal qual praticada na Pedagogia Freinet. Esse direcionamento didático foi discutido, a propósito, em nossa dissertação de mestrado (MOREIRA, 2014).
} 
mais velhos. A autora acrescenta que, mesmo que o resultado não seja digno de ser compartilhado na prática musical em grupo, não seria isso um problema, visto que é a própria abertura para a criação e o sentimento de autoconfiança agregado à esta que se visa prioritariamente.

Sob uma perspectiva atual e orientada pelos estudos da infância, a leitura de um discurso de preservação da originalidade das crianças pequenas em relação à influência de pessoas mais velhas - tanto adultos quanto crianças maiores - aparece como demasiado simplista. É evidente que a cultura infantil tem marcas de especificidade se comparada à cultura adulta, no entanto, segundo Sarmento (1997, n.p), "as culturas infantis não nascem no universo simbólico exclusivo da infância, este universo não é fechado - pelo contrário, é, mais do que qualquer outro, extremamente permeável - nem lhes é alheia a reflexividade social global”. Para uma maior compreensão de como as crianças operam em trocas culturais entre seus pares, é necessário levar em consideração que estas culturas não se formam de maneira espontânea nem alheia, ao mesmo tempo em que não se restringem à mera reprodução ou imitação direta do mundo adulto. O funcionamento da reprodução interpretativa, segundo Corsaro (2009), se dá na medida em que as crianças produzem suas próprias culturas de pares ao se apropriarem de elementos do mundo adulto de maneira criativa. Essa apropriação não apenas amplia as culturas infantis, como também contribui para a reprodução da cultura adulta. Sendo assim, apontamos que esses textos apresentam incontestável pioneirismo na medida em que atentam para as especificidades expressivas das crianças pequenas em situação de criação musical, contudo, ainda apresentam visão demasiadamente restrita quando não consideram as trocas culturais no mundo infantil em toda sua complexidade.

O pioneirismo em reavaliar esteticamente os produtos de criação infantil, como já apontamos, se mostra de maneiras distintas de acordo com a área artística e é ainda presente em nosso tempo. Em se tratando das publicações aqui analisadas, destacamos que, no artigo de Steele e Lillard (1932), as comparações com as artes visuais já estavam colocadas de maneira a denunciar o déficit de abertura da educação musical. Acreditamos que este é um dos textos, dentre os materiais aqui analisados, que apresenta singular importância pela conjugação de pensamento pedagógico e estético no determinado período. Essa conjugação se apresenta também em outras passagens, que serão abordadas ainda nessa seção e configuram pequenas aberturas para a reconsideração dos resultados das atividades criativas musicais das crianças. 
Com a análise de tal material, apontamos para o necessário alargamento de fontes na construção da historiografia da educação musical. Faz-se necessário abarcar as inovações que extrapolam a organização esquemática em apenas duas gerações de educadores musicais comprometidos com a proposição de métodos ativos no século XX, possibilitando uma visão mais complexa sobre a área. A asserção de que as inovações estéticas só encontram ecos na educação musical a partir da década de 1950 abordada em nosso primeiro capítulo, por exemplo, pode ser aqui contestada, na medida em que nos debruçamos sobre arquivos não antes considerados sob este aspecto. Em nosso estudo, ressaltamos, buscamos essa ampliação de fontes tomando produções que não restritas a cenários especificamente musicais, como escolas de música e conservatórios, e sim aquelas onde a música aparece integrada em movimentos pedagógicos de renovação da instituição escolar.

As autoras Steele e Lillard (1932), em texto intitulado Creative music in the group life, denunciam a assimetria entre os avanços na educação em artes visuais e em música, invocando a necessidade de uma postura experimental por parte dos educadores:

\begin{abstract}
Em música, no entanto, nós nem sonhamos com os resultados da assunção da mesma atitude que temos hoje em arte - a ideia de que as crianças têm algo a dizer em seu próprio idioma. Estamos apenas no início dessa compreensão e provavelmente teremos que vivenciar todos os níveis de estágios experimentais até que nós, como professores, consigamos entender como lidar com a criança de maneira musical (STEELE; LILLARD, 1932, p. 125)
\end{abstract}

Essa postura experimental se esclarece na medida em que, mais adiante, as autoras estabelecem a relação entre a abertura para as práticas criativas das crianças e a ampliação de repertório do professor. $O$ trecho a seguir conjuga exemplarmente ideias escolanovistas - como a busca por uma observação apurada e objetiva da criança e a conferência de valor a sua atividade como especificidade de um momento a ser respeitado em seu desenvolvimento - e uma atitude de aproximação com as inovações que ampliavam as ideias de música em voga nos círculos composicionais na primeira metade do século XX.

Nós estamos, todos, repletos de preconceitos musicais [...]. Os modernistas, apreciemos sua música ou não, ao menos abriram nossas mentes para novas concepções musicais, novos intervalos, novas escalas, novos ritmos, novas relações. Para mim, a 
compreensão de que a atonalidade quebra nossa velha dependência da tonalidade, que não é necessário finalizar em uma nota ou em um acorde que resolve o que se passou antes, significa que se deve deixar a imaginação musical ir a planos distantes, assim como os artistas modernos fazem nas relações espaciais. Com isso não quero negar a beleza da grande música do passado. Tampouco quero superestimar a expressão musical contemporânea. Eu digo apenas que, dos músicos de hoje, nós, como professores, devemos apreender uma nova atitude musical, ou ainda, uma nova atitude diante da música e da criança. Acredito que devamos assumir com a música a mesma atitude que assumimos com a pintura ou com a língua - que a criança deve ser observada objetivamente mais do que vem sendo observada. Nós devemos prover um ambiente musical onde seus conceitos musicais, em qualquer ponto de seu desenvolvimento, possam se mostrar livre e alegremente e possam ser recebidos com naturalidade e respeito, sem fazer a criança sentir que sua técnica precisa ser desenvolvida antes de seu poder criativo (STEELE; LILLARD, 1932, p. 125 - 126)

Os trechos acima nos permitem afirmar que houve uma aproximação entre pensamento pedagógico e estético de viés progressista no cenário analisado. Contudo, a leitura de tal discurso imbuído de denúncia e apelo experimental não nos garante que essas ideias tenham tomado forma de ação pedagógica, tampouco que uma ação pedagógica assim orientada seria facilmente bem sucedida. Para além da vontade de renovação das educadoras, atentamos para as marcas de realização de tal intuito no decorrer do texto. Mesmo que saibamos dos limites que certamente possui um relato produzido como parte da argumentação anterior, apontamos duas informações como pertinentes para a compreensão dos desdobramentos didáticos de tal pensamento.

A primeira diz respeito à conduta do educador. Em vários momentos as autoras esboçam as qualidades esperadas de tal agente, das quais destacamos a afirmação de que as crianças, quando sentem a necessidade de compor uma música, devem "[...] encontrar alguém que acredita que elas podem criar e que tenha habilidade para ajudá-las a moldarem seus pensamentos musicais em qualquer forma que estes tomem" (STEELE; LILLARD, 1932, p. 126). Essa postura de abertura às diversas formas que o pensamento musical pode ter está em concordância com a aproximação à música de vanguarda e aponta para uma possível realização do ideal apresentado.

Quando as autoras falam expressamente de experiências com as crianças, temos uma segunda aproximação de como as ideias se desdobram na prática pedagógica. Os relatos são sobre composições de canções e estas fazem parte de projetos maiores, como um estudo sobre a época medieval e a produção de texto e de 
uma peça de marionetes com esta temática. É interessante observar que, para esta peça, as crianças compuseram quatro canções, passando por quatro processos criativos diferentes. As duas primeiras foram composições originais, sendo que a segunda foi delegada a um grupo menor, visto que a grande quantidade de crianças dificultou o processo composicional da primeira canção. A terceira foi uma paródia, então as crianças criaram apenas a letra para uma melodia dada de antemão. O quarto processo criativo se deu a partir da escuta de repertório medieval e deu origem a uma peça diferente. Após escutar várias vezes o repertório trazido pela educadora, as crianças discutiram sobre os sentimentos sugeridos por esse tipo de música e duas delas decidiram escrever um texto como recitativo aliado à música medieval como fundo. Segundo as autoras (idem, 1932, p. 128), "aqui as crianças encontraram uma linguagem expressiva para o caráter da música, uma espécie de narração musical muito próxima estilisticamente do recitativo moderno". Acreditamos que com esses exemplos, as autoras demonstraram ser possível guiar os processos criativos das crianças com alguma abertura, sem deixar de lado as trocas culturais implicadas no ato de criação.

A partir da constatação de que as práticas de composição e improvisação figuram de maneira evidente nas publicações de tal dossiê, publicado originalmente em 1927, e demonstram pioneirismo nas implicações do pensamento pedagógico progressista sobre a educação musical, dedicamo-nos a identificar as justificativas aí apresentadas. Com alguns exemplos de como os argumentos se apresentaram nestes primeiros anos da periodização, acreditamos fornecer uma leitura esclarecedora sobre o cenário da Progressive Education no final da década de 1920 e suas especificidades em nossa área, mais especificamente sob o foco das práticas criativas.

Encontramos distintas maneiras de argumentar pelas práticas de composição e improvisação no ensino de música dentre os artigos. Algumas, por seu teor e por não apresentarem ligação direta com exemplos da ação pedagógica, nos parecem pouco dignas de nota. Um exemplo é a ideia sustentada por Seymour (1932) de que a criação artística deve ter lugar no desenvolvimento da criança pois seria, na verdade, a manifestação de um poder criativo maior e metafísico. Mesmo que consideremos a importância de vertentes teosóficas nos movimentos escolanovistas, sobretudo na Europa (BREHONY, 2004; CONDETTE e SAVOYE, 2016), não nos dedicamos a esta consideração pois a mesma não encontra ecos mais concretos no próprio artigo, tampouco no conjunto de materiais aqui considerados. 
De uma maneira geral, a prática criativa é defendida como meio de desenvolver uma melhor compreensão formal e domínio dos meios de expressão (GOODRICH, 1932), como provedora de autoconfiança e consciência (POTTER, 1932), do aumento do interesse e da melhora expressiva de crianças tomadas ordinariamente como não talentosas (CADY, 1932), e por ter como consequência uma escuta mais inteligente e uma curiosidade pelos aspectos técnicos da arte musical (STEELE; LILLARD, 1932).

Uma argumentação nos é dada por Newman (1932) e, mesmo que apareça de maneira não desenvolvida, a consideramos relevante. Quando relata que às crianças são dados o incentivo e a oportunidade de criarem suas próprias músicas, elas são levadas a perceber que não é possível fazê-lo sem antes refletir e imaginar o que tomará forma de expressão musical. A prática da composição garantiria, assim, mesmo que ainda de maneira elementar para as crianças pequenas, uma postura ativa e um engajamento refletido.

Para finalizar nossas considerações relativas ao dossiê e de maneira a conectar seu conteúdo aos materiais posteriores, destacamos um trecho do artigo de Davis (1932) sobre o papel dos processos criativos na educação musical onde parece expressa a tensão entre a centralidade da criança e dos conteúdos e disciplinas escolares, tensão esta característica das discussões escolanovistas

Esse trabalho me parece valioso apenas como um meio, não como um fim. Essas práticas em demasia tomam o tempo que pode ser empregado cantando músicas muito melhores; e pode, ainda, dar à criança a impressão de que a música é centrada nela, quando ela deveria aprender a deixar-se perder na música (DAVIS, 1932, p. 79)

Tal trecho nos permite afirmar que a valorização dos processos criativos não era unânime no cenário e, mesmo entre os educadores que a defendiam, não existia consenso sobre seu papel no ensino de música. Neste sentido, é exemplar que dez anos mais tarde, em 1937, encontremos o tema em um relatório da seção de música da Francis Parker Conference. O relatório, redigido por Whit Brogan, trata de um encontro de educadores ${ }^{36} \mathrm{e}$, dentre as questões para as quais não se apresentou

\footnotetext{
${ }^{36}$ Apresentamos aqui os nomes dos educadores e das instituições às quais estavam vinculados tal como aparecem no relatório. Beatrice Perham Krone, diretora do Departmento de Música, Ohio State Demonstration School, Columbus. Roberta Green, Glencoe Public Schools, Glencoe, Illinois. Whit Brogan, School of Education, Northwestern University. Lulu Kilpatrick, Supervisora de Música, Cicero, Illinois, e presidente do In-and-About Chicago Music Supervisor's Club. Russel Paxton, diretor
} 
consenso possível, estava a seguinte: "Qual é o lugar das composições infantis em um programa de ensino, se comparadas ao lugar da "música dos mestres"?" (BROGAN, 1937, p. 643).

A composição das crianças aparece aí em contraposição a um repertório a ser aprendido. Essa contraposição marca a disputa pela valorização das criações infantis que, defendemos aqui, já estava em vias de se estabelecer - e pelo lugar da prática composicional como um dos vários aspectos constitutivos da área que precisavam disputar seu espaço quando se tratava de organização temporal. Nas críticas de Surette abordadas na seção desta tese dedicada ao trabalho de Satis Coleman, bem como no artigo de Davis (1932) que citamos anteriormente, o fator de organização temporal aparece como parte do argumento contra uma valorização exacerbada dos processos criativos. E, como também desenvolvido na seção sobre as diferenças entre os dois educadores, por vezes a contraposição aos processos criativos exprime uma tensão acerca do papel da educação como meio de reprodução cultural através do currículo e da centralidade das disciplinas e dos conteúdos na organização escolar.

Acreditando que os discursos adquirem, por vezes, tom demasiado militante e que isso pode nos levar a uma visão pouco complexa da situação, destacamos um artigo no qual a importância do currículo e a valorização da criança são discutidas de maneira conectada com um experimento concreto. Trata-se de texto de Beatrice Perham, onde a autora descreve o que intitula "um ambiente musical" na escola de educação básica da Ohio State University. A autora afirma que "O currículo musical deve ser flexível de maneira a tratar dos interesses e necessidades das crianças enquanto elas crescem. Por outro lado, ele deve ser balanceado o bastante para trazer variedade e riqueza para a bagagem de referências de cada criança" (PERHAM, 1935, p. 410).

Observamos, então, no texto, como se organizavam as diferentes atividades musicais e o papel ocupado pelos estímulos criativos em um espaço que buscava atender tanto os interesses das crianças quanto a necessidade de ampliação de referências. Para as crianças pequenas é construído um ambiente exploratório, descrito como um espaço onde elas podem experimentar livremente com instrumentos - convencionais e inventados, geralmente construídos na escola -, vitrola, partituras de composições das crianças em diversos modos de notação, discos e livros. Além 
dessa sala de música, há ainda "cantos" com instrumentos em outros lugares da escola. O período exploratório situa-se, segundo a autora, nos dois primeiros anos de escolarização.

Para os mais velhos há, além de aulas regulares em grupo, trabalhos individuais ou em pequenos grupos, os chamados trabalhos de "livre escolha", dentre os quais, alguns são ligados à música.

Algumas das atividades de livre escolha oferecidas em nossa escola e que acontecem duas vezes por semana são na área de música. Elas são eletivas realmente especiais. Cada criança faz sua escolha consciente de que deverá se dedicar durante doze semanas em cada atividade de livre escolha. Música instrumental, orquestra, ritmos, opereta, construção de instrumentos são algumas das atividades de livre escolha oferecidas que colaboram para o enriquecimento da experiência da criança em música (PERHAM 1935, p. 410)

Na sequência, a autora dá dados sobre a participação ${ }^{37} \mathrm{em}$ formações como os coros, contando com uma média de quarenta alunos cada; o grupo de saltérios, com dez alunos; a orquestra escolar, com dezesseis alunos; e sobre o livro feito para anotar alguns dos resultados das atividades de composição. Neste livro constam peças de 28 crianças, sendo que cada uma contribui entre uma e seis vezes, além de peças de composição coletiva. Ao falar dos trabalhos feitos de maneira livre em horário extraclasse, a autora (PERHAM, 1935) apresenta exemplos de uma observação de duas semanas. Neste trecho, os trabalhos são majoritariamente criativos.

Oito crianças trabalharam em composições individuais de canções. Quatro crianças trabalharam em grupo compondo um hino para uma peça.

Um garoto escreveu algumas transposições de canções para seu clarinete.

Um garoto escreveu a abertura de uma opereta que foi tocada pela orquestra.

Um garoto escreveu acompanhamentos ao piano (usando apenas acordes de I e V graus) para peças tocadas pelo grupo de saltérios (PERHAM, 1935, p. 411)

Após a descrição do ambiente de exploração musical para os primeiros anos e das diferentes atividades musicais que se seguem na vida escolar, a autora relata

\footnotetext{
${ }^{37}$ Apesar de não apresentar os dados com rigor - o que se mostra pela falta de informações precisas sobre a quantidade de turmas e o total de crianças - a autora sugere que a participação nas atividades musicais eletivas é alta na medida em que afirma que apenas 18 crianças não se engajam. Contudo, salienta que essas mesmas crianças participam de maneira satisfatória das aulas regulares de música.
} 
alguns processos de criação e encerra o texto com considerações sobre a formação do gosto e sobre a necessidade de reconhecer as crianças em suas especificidades, estimulando-as de acordo com seu desenvolvimento. Apesar das considerações iniciais sobre o currículo, a autora não explicita de que maneira os conteúdos se organizam, dando-nos a impressão de que estes surgem e são abordados de acordo com as práticas interpretativas em grupo e com as atividades de criação. Sobre o lugar do repertório histórico, a autora pondera que é muito complexo dar à apreciação das crianças peças que estão muito distantes de seus próprios meios de expressão e compreensão, mas que os educadores devem estar comprometidos com a ampliação de referências e com o aumento dos níveis de julgamento no curso do desenvolvimento dos alunos.

O texto de Perham (1935) se encerra com o reforço de uma ideia característica dos movimentos pedagógicos de renovação escolar, a saber: a necessidade de partir das especificidades da criança para guiá-la no processo educativo ${ }^{38}$. Em nossa tese, defendemos que essa característica, bem como o pensamento escolanovista de uma maneira geral, encontra sua manifestação em educação musical através, sobretudo, do estímulo ao processo criativo. E a consideração da criança como agente no ambiente escolar tem como desdobramento, em nossa área, a reconsideração dos seus modos de expressão musical. A abertura estética já presente no texto de Steele e Lillard (1932), datando do início de nossa periodização, se confirma em alguns exemplos identificados em materiais dos anos subsequentes.

O texto de Donald Pond, publicado em 1936, tem como objetivo discutir o papel social da música na infância. Logo no início do texto, Pond (1936) faz eco às denúncias de Steele e Lillard (1932) no que concerne à falta de conhecimento de repertório por parte dos adultos e afirma que essa carência é um impedimento para a compreensão das relações que as crianças estabelecem com a música. O autor encaminha seu argumento no sentido de defender que, a partir da prática da composição, as crianças criam algo que, em um primeiro momento, tem valor para si mesmas, mas que vem também a ganhar espaço em seu grupo e em outros grupos. A composição musical é apresentada e defendida como prática que liga indivíduo e

\footnotetext{
${ }^{38}$ A compreensão de que o trabalho da autora é um exemplo de educação musical orientada pelo ideário pedagógico renovador não é apenas uma interpretação nossa. Consta no vol. XVI, ano de 1939, propaganda de uma série de livros assinada por Beatrice Perham que, além de intitulada Music in the new school, é apresentada neste anúncio como "A única série de livros musicais infantis escrita expressamente para escolas progressistas" (PROGRESSIVE EDUCATION, 1939, p. 212)
} 
grupo, daí, segundo o autor (POND, 1936), sua função social. O autor dá como exemplo a tarefa de criar músicas para um espetáculo de teatro. Ele afirma que nesse momento as crianças se confrontam com a necessidade de dar formas objetivas às suas emoções, e que quando buscam isso sem convenções musicais restritas são capazes de fazer experiências significativas.

Em meio a esta reflexão sobre a ação social das crianças que compõem, Pond (1936) esforça-se por defender que os modos de expressão infantis não são os da música convencional.

Descobri que quando a criança é ajudada a se sentir livre para compor como ela quer, sua música geralmente não é em tonalidade maior nem menor. Eu tenho músicas de crianças em modo jônio e mixolídio, em escalas pentatônicas, em escala menor natural, e músicas que podem ser descritas como atonais. Algumas contêm subdivisões da oitava menores que semitons. No aspecto rítmico, geralmente são muito fluídas. Expressando em um termo talvez incorreto, pode-se dizer que são não rítmicas. Grupos de cinco e sete são tão frequentes quanto aqueles de três, quatro ou oito. $\mathrm{O}$ sentimento de cadência é realmente notável; as melodias não terminam tanto como se fossem abandonadas, mas mais frequentemente por uma lógica interna, que eu dificilmente inventaria (POND, 1936, p. 177)

Mais adiante o autor sugere que, em vez de dizer como as crianças devem compor, os adultos são responsáveis por ajudá-las a "pensar música" (POND, 1936, p. 178).

No ano seguinte, identificamos uma referência que viria se repetir e ser desenvolvida em 1938, a saber: uma consideração de Leopold Stokowski sobre a diminuição da criatividade das crianças a partir dos oito anos de idade. Em sua primeira ocorrência, trata-se de uma pequena citação desvinculada de qualquer artigo, onde lemos que o autor identifica o fenômeno e o associa ao consumo de músicas prontas. Nesta nota lemos ainda que as crianças, submetidas constantemente à produção musical adulta, passam a acreditar que a sua própria não possui valor (STOKOWSKI, 1937).

Tal ideia é retomada por Madeleine Dixon em artigo de 1938. A autora concorda com o diagnóstico de Stokowski, no entanto, atribui outras causas ao decréscimo criativo das crianças na idade determinada. Segundo a autora (DIXON, 1938), as crianças passam de uma postura musical mais ligada à exploração e à 
improvisação para uma necessidade de produzir composições na medida em que crescem e tomam mais consciência de si e de padrões e formas. Essa mudança implicaria, de acordo com a hipótese da autora, em um bloqueio da criatividade devido à necessidade de organização formal e a falta de habilidades para tal. Assim, ela defende que se conduza o processo de criação musical de maneira a suprir a necessidade formal das crianças na medida em que elas crescem. $O$ ensino de "técnicas" viria como meio de transformar as ideias musicais em formas, e isso não poderia ser feito a partir de repertório restrito. Em suas palavras:

De repente, ela [a criança] passa a ter padrões e estima as coisas pela sua forma, perfeição e clareza [...] Nós faríamos melhor nos antecipando e incorporando técnicas mais cedo. Talvez levá-las a, conscientemente, transformarem uma improvisação em uma composição finalizada, aprendendo quais ferramentas propiciam clareza e organizam as ideias em formas [...]. Acredito que devamos reconhecer abertamente que, neste período, as crianças são rigorosas em termos formais. Devemos aceitar isso, mas deixandoas conscientes dos experimentos formais radicais que os artistas fazem atualmente. Sem exclusividade para o antigo, nem para o novo (DIXON, 1938, p. 488)

A referência a Stokowski se repete alguns anos mais tarde, em 1944, mas não mais como discussão da asserção sobre a criatividade infantil, e sim em forma de texto dedicado a um livro do regente, intitulado Music for all of us. $\mathrm{O}$ artigo é uma resenha elogiosa assinada por Susan Keep e traz alguns dos assuntos do livro. Deste texto, destacamos duas passagens onde fica marcada a diferenciação entre adultos e crianças em se tratando de expressão e apreciação musicais.

A primeira passagem que nos chama a atenção trata de um caso em que um menino vai a um concerto pela primeira vez e, contrariando as expectativas dos adultos, afirma que sua parte preferida foi o momento da afinação da orquestra. Keep (1944) enfatiza que essa história pode fazer rir em um primeiro momento, mas é prova de que as crianças estão despertas para sonoridades ignoradas pelos adultos. Ele escutou sons "desorganizados, frases dissonantes ao acaso, vibrações estranhas, mistura de instrumentos raramente orquestrados, etc.” (KEEP, 1944, p. 115) e os preferiu à sinfonia tocada na sequência.

Há outro trecho apresentado pela autora que se aproxima ainda mais de nossa tese, porque ligado à prática criativa e à relação entre adultos e crianças. Ela apresenta como contraproducente o ato de transcrever melodias compostas pelas crianças e que 
não são temperadas, adequando-as às divisões convencionais a partir de semitons. Isso, segundo a autora (KEEP, 1944, p. 115), faria com que essas criações perdessem "o charme verdadeiro de suas ideias originais". Ela assume que se sentiu envergonhada ao ler o livro de Stokowski, pois percebeu que muitas vezes escondia "novas ideias em velhas escalas tentando ser progressista". Para esse problema, Stokowski (1943) sugere em seu livro que os adultos gravem em áudio as composições das crianças, conferindo fidelidade na manutenção de suas invenções, mesmo que seja para uma posterior desaprovação de quem compôs.

Haveria ainda outros exemplos dentre os conteúdos identificados na revista sobre o incentivo à criação musical na infância, haja vista a quantidade de 48 ocorrências do tema, como já apresentado anteriormente em tabela. Os conteúdos selecionados e comentados aqui são exemplares na medida em que nos permitem compreender como os processos criativos ocuparam um lugar privilegiado em projetos de educação musical orientados pelo ideário pedagógico dos movimentos de renovação escolar. As práticas de improvisação e composição estavam presentes nos materiais, bem como alguma abertura para a reconsideração estética dos produtos dos processos criativos das crianças.

Em seguida, apresentamos breves considerações sobre dois dos demais temas identificados na revista, a saber: o repertório e o folclore, e as novas tecnologias. Mesmo que nosso foco esteja na temática do papel da criação musical, as considerações que se seguem nos servem a compreender um pouco mais do cenário e da busca por coerência entre educação musical e o projeto pedagógico progressista, sobretudo em suas marcas de especificidade e pioneirismo.

\section{Repertório e folclore}

As discussões que tratavam do tema "repertório" no material analisado o abordavam, sobretudo, a partir de duas perspectivas, a saber: a necessidade de ampliação do repertório de educadores e a valorização do repertório folclórico. As abordagens se davam de diversas formas: através de artigos e resenhas que o tomavam de maneira principal ou periférica; constituindo o próprio objeto da produção textual, como nas listas de sugestão de escuta de Lorraine St. Amande mencionadas anteriormente; e, algo singular, o repertório educacional foi também encontrado tematizado em campanha publicitária. 
A ocorrência de anúncios publicitários da empresa RCA Victor é notável nos últimos anos de nossa periodização. Esse material diz respeito, sobretudo, ao uso de aparelhos tecnológicos na escola, mas aqui destacamos um anúncio veiculado no ano de 1939 onde a empresa divulga um disco de repertório coral dos séculos XV, XVI e XVII cantado pela Família Trapp (Fig. 1). Além da publicidade do disco em questão, a gravadora anuncia um catálogo de discos destinados à escola em todos os níveis, especialmente elementar, onde seria possível encontrar "toda a música que você [o educador/ leitor da revista] precisa para proporcionar às crianças um verdadeiro conjunto de referências para a apreciação musical" (PROGRESSIVE EDUCATION, 1939, p. 289). Em outro anúncio (PROGRESSIVE EDUCATION, 1940, p. 145), o catálogo da RCA Victor aparece como sendo de muita utilidade para a organização do repertório de educação musical. Neste anúncio figura uma personagem desenhada representando uma professora que afirma: "Meu catálogo de gravações RCA Victor me ajuda nas aulas de música quase todos os dias".

Causa-nos interesse tais anúncios, na medida em que nos mostram o tema do repertório musical sendo abordado em textos não argumentativos, nem de relatórios de prática pedagógica, mas apropriado por um discurso comercial. A gravadora afirma que seus produtos são desenvolvidos por "proeminentes educadores" (PROGRESSIVE EDUCATION, 1939, p. 289), porém, não os nomeia. O anúncio traz, ao final, um slogan que retomaremos ao tratarmos da presença de novas tecnologias na revista: "Escolas modernas mantêm-se modernas com os rádios da RCA em seus equipamentos de som" (idem). 


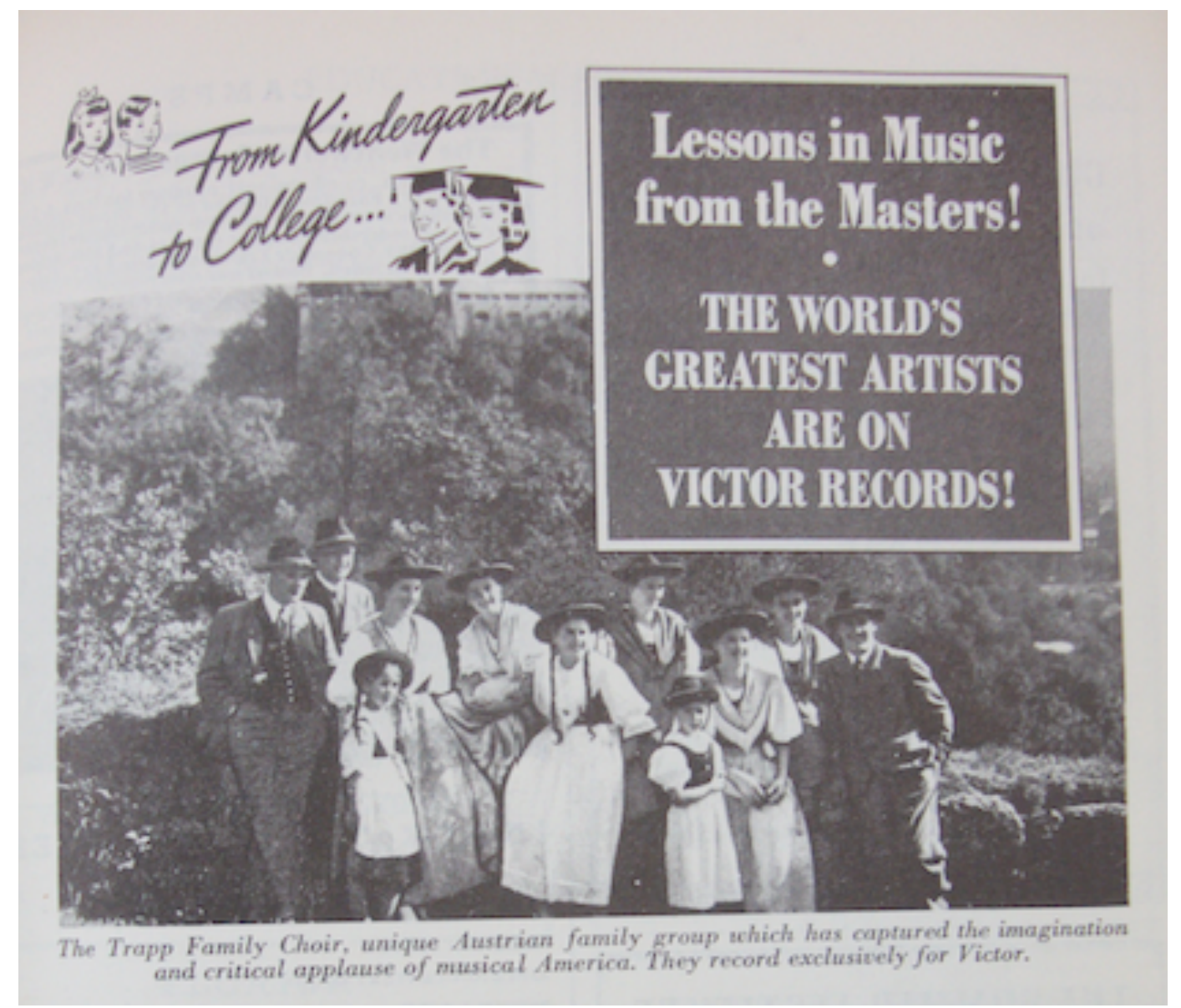

Figura 1 - Excerto de anúncio publicitário da RCA Victor (PROGRESSIVE EDUCATION, 1939, p. 289)

O repertório folclórico figura em relatos de prática pedagógica e não diz respeito apenas ao folclore local, mas também às músicas tradicionais de países estrangeiros. São exemplares três textos ${ }^{39}$ da publicação de março de 1935 nos quais a música é fator constituinte de projetos maiores. Um dos textos trata de uma escola indígena, enquanto os demais se referem ao estudo de culturas afro-americana e chinesa. Toda essa publicação, a propósito, tem caráter que hoje nomearíamos multiculturalista. A consciência de que o país se constituía de diversas culturas e algum incômodo com a forte segregação racial perpassam, de maneira nem sempre explícita, os conteúdos da revista.

Quanto às justificativas expressas em favor da música folclórica, temos aquela apresentada anteriormente, oferecida por Collins Jr. (1938), que atribui à escola a tarefa de preservar tal repertório, visto que a industrialização e a urbanização o

\footnotetext{
${ }^{39}$ KRAMER, Max. "An experiment in indian education.” P. 155 - 159. WHITING, Helen A. "Negro children study race culture". P. 172 - 180. SPESSARD, Katharine H. "Appreciating China in America”. P. $202-205$.
} 
tiravam de circulação pelos meios de convivência familiar e comunitária. O mesmo autor (COLLINS Jr., 1942, p. 14) apresenta ainda um argumento fundamentado no ideário escolanovista, quando afirma que "partir de onde o aluno se encontra, em música, significa partir de sua herança musical, da experiência não escrita que se expressa na música folclórica americana". Tal asserção constitui uma interpretação singular do lema escolanovista de partir da criança para construir os processos de ensino e aprendizagem, pois não encontramos tal argumentação em produções dos demais autores.

Os enunciados relativos a este repertório são, se tomados em sua totalidade, uma amostra ambígua. A valorização de músicas tradicionais de culturas minoritárias estadunidenses, como as autóctones ou de ascendência africana, exprimem um viés de pensamento nacionalista. O país se concebe como multicultural, entretanto, existe uma concepção de que essas músicas seriam próprias à infância porque pouco complexas, em uma posição de exotismo romântico e inferioridade (SURETTE, 1932; NEWMAN, 1932). A valorização de tal repertório também estava ligada a uma postura engajada de alguns educadores que viam como necessidade tornar o país mais musical, denunciando a falta dos hábitos de escuta, interpretação e criação da população estadunidense. Essa valorização se constrói tanto em oposição à cultura europeia - quando defendem o cultivo da música folclórica nacional - quanto em comparação a esta cultura - quando afirmam que as populações dos países europeus estariam mais envolvidas com as práticas musicais e ao apresentarem, como meio de validação do folclore, o fato de o mesmo servir de material ou inspiração composicional para a música de concerto (SURETTE, 1932; BROGAN, 1937; COLLINS Jr., 1938).

Há ainda as ocasiões nas quais o tema do repertório é tratado não de maneira a limitá-lo ao folclore, mas com vistas à sua ampliação. Como já exposto em seção onde tratamos dos conteúdos da revista relativos à criação musical, um repertório amplo é visto como condição para que os educadores consigam guiar as crianças em seus processos composicionais. Destacamos, da mesma maneira, o seguinte trecho de Rosentrauch (1944), que em texto intitulado Music education of tomorrow, defende que o alargamento do repertório em meio educacional é necessidade de todos e condição para fruição de músicas diversas. Em suas palavras: "A distância entre o compositor moderno e seu público é extremamente grande. Qualquer que seja a escolha pessoal, os ouvidos devem ser preparados desde a infância para a escuta tanto 
de padrões sonoros modernos, quanto daqueles de séculos precedentes" (ROSENTRAUCH, 1944, p. 133).

\section{Novas tecnologias}

Que um movimento de tendência progressista nos Estados Unidos do período entre-guerras tenha, em seus arquivos, menções ao uso de novas tecnologias, não nos poderia surpreender. Em se tratando de educação musical, os aparelhos de gravação e reprodução sonora estão vinculados a uma postura pedagógica experimental, ao mesmo tempo em que seus usos despertam considerações de diversas ordens.

Retomamos a menção feita anteriormente às propagandas da empresa RCA Victor e seu slogan "Escolas modernas mantêm-se modernas com os rádios da RCA em seus equipamentos de som". Esse enunciado publicitário nos dá a ver uma estratégia comercial que conjuga a ideia de modernização do ensino e da instituição escolar, algo caro ao movimento progressista, à aquisição de alguns equipamentos. A primeira propaganda identificada consta em publicação de março de 1938, à qual se seguem 12 outros anúncios até 1940. Dentre os produtos anunciados encontramos sistemas de som que distribuem alto-falantes por toda a escola a partir de um controle central, gravadores, discos virgens, vitrolas, discos gravados, rádios, etc.

O slogan supracitado é apenas um dos enunciados que associam a ideia de uma educação modernizada aos aparelhos. Estes aparecem sempre como uma necessidade da escola que se considera progressista. Em um primeiro momento, a simples associação entre a aquisição dos aparelhos e o caráter moderno de uma escola parece ter presença bastante efetiva na revista, pois as propagandas repetem-se com frequência em um curto período e os produtos parecem se multiplicar. No entanto, identificamos uma nota de grande pertinência na publicação de outubro de 1940. A nota parece ser redigida pelo editorial, pois não traz assinatura, e trata de um livreto publicado pelo Comitê de Ajuda Científica ao Aprendizado, situado na cidade de Nova Iorque. O livreto é um relatório sobre os sistemas de som que vinham sendo adquiridos pelas escolas, com avaliações visando a apontar suas especificidades, suas vantagens e desvantagens, sua adequação aos diferentes ambientes escolares, etc. A publicação é apresentada como uma maneira de evitar a aquisição de "elefantes brancos" que trariam gastos injustificáveis para escolas onde o aparelho não tivesse real serventia. Destacamos o trecho seguinte como um exemplo de que o discurso 
publicitário de identificação direta entre modernidade educacional e a aquisição de aparelhos específicos encontrava resistência refletida: "Talvez sejam particularmente precisos seus [do livreto] comentários de que a mera existência de um sistema de som central não determina, por si só, uma escola moderna; e que não há nada em que o sistema de som possa contribuir, por si só, para uma escola" (CENTRAL, 1940, p. 381). Parece-nos, portanto, que juntamente à movimentação comercial conectada ao avanço tecnológico e sua possível contribuição para um projeto educacional que se queria moderno, fazia-se necessária a discussão sobre os usos de tais tecnologias.

Encontramos, nos materiais analisados, algumas referências ao uso de novas tecnologias no ambiente educacional. Há exemplos de espaços de exploração, onde as crianças têm liberdade para usar objetos, dentre os quais há vitrolas e discos (PROGRESSIVE EDUCATION, 1929; 1935; 1940), e indicações de tais materiais. Nestes casos, as novas tecnologias de gravação e difusão servem especificamente à apreciação musical. Porém, as vantagens da música gravada não aparecem sem alguma resistência.

A rádio, por exemplo, é usada pela própria associação como meio de difusão e também para programas de apreciação musical, no entanto, não escapa às considerações que a ligam à uma postura passiva ou às críticas ao repertório que tem produção e difusão ligadas a ela. No texto Music education of tomorrow, Henrietta Rosenstrauch comenta que, antes de ter lições de harmonia ou contraponto, os estudantes deveriam ter uma iniciação à prática musical por atividades de escuta, improvisação e performance. Esse processo, segundo ela, os aproximaria da música de maneira a aprofundar sua compreensão e garantiria um quadro de referências pela escuta. Ela afirma que isso seria necessário pois os estudantes, em sua maioria, "têm sido saturados com jazz, canções sentimentais e músicas similares que escoam dos rádios" (ROSENSTRAUCH, 1944, p. 145). A educadora afirma, mais à frente, que a música deveria ser algo em que todos participam, não "mera performance, entretenimento, sensação, escape, como muito frequentemente é o caso" (idem). A associação do hábito de escuta de rádio à passividade ou críticas ao repertório aí difundido são encontradas também, com diferentes nuances, nos materiais de autoria de Satis Coleman que serão abordados em seguida, e, sobretudo, nos materiais do movimento francês.

Interessa-nos, além da novidade que a difusão traz para a escola neste momento, a prática da gravação no ambiente escolar. Nos anúncios da RCA Victor, 
quando relativos a aparelhos e discos para gravação, a educação musical é tematizada. Os produtos são apresentados como úteis para a avaliação dos progressos das crianças tanto nas aulas de música, quanto em aulas de línguas. Identificamos em texto de 1933 um relato de que a prática de gravação era usada em aulas de música, portanto, ainda cinco anos antes da série de anúncios publicitários. $\mathrm{O}$ artigo é assinado por David Dushkin, cujo pioneirismo já foi aqui abordado. A menção ao uso de gravador aparece de maneira a corroborar o que o educador apresenta como princípios de sua abordagem, a saber: a necessidade de desenvolver a iniciativa, a responsabilidade e a autocrítica, com vistas à autonomia dos estudantes. Para tanto, o gravador aparece como ferramenta:

A esse respeito, um dispositivo que temos usado com grande serventia é um equipamento profissional de gravação, que registra instantaneamente com muita qualidade. Isso permite aos indivíduos e aos grupos de estudantes escutarem suas performances imediatamente após elas serem finalizadas. Essas gravações servem não apenas como incentivo para uma performance de maior excelência e precisão em detalhes para os estudantes, mas também como um memorando inestimável para todos os professores, mostrando o progressos dos alunos (DUSHKIN, 1933, p. 149)

De uma maneira geral, a utilidade do gravador parecia atrelada à avaliação por parte dos educadores nos anúncios dos produtos. Contudo, a indicação de que o dispositivo servia às considerações dos próprios alunos e seu uso estava de acordo com a valorização da autonomia e da iniciativa dos mesmos, parece-nos digno de nota, expressando um ponto de coerência entre o pensamento pedagógico progressista e as práticas de ensino de música.

Reiteramos, então, que as novas tecnologias estiveram tematizadas nos materiais da Progressive Education. Isso se deu tanto por estratégias comerciais, quanto por considerações pedagógicas em relação às mudanças nos hábitos musicais daí decorridas. As relações aí estabelecidas são expressivas de uma época de grandes mudanças sociais. Estes materiais, bem como outros complementares, podem constituir fonte profícua para um maior entendimento das relações geracionais e pedagógicas e sua relação com a indústria cultural no período específico. Sinalizamos, assim, a necessidade de tomar essas produções em pesquisas futuras não apenas no domínio pedagógico ligado à didática, mas em sua potencial contribuição para estudos de intersecção entre educação, história, sociedade e cultura. 
Partindo da análise da revista Progressive Education e de seus conteúdos concernentes à educação musical, apresentamos uma seção dedicada ao trabalho de Satis Narrona Coleman. O pioneirismo e a centralidade da educadora para o movimento estadunidense e também em contexto internacional serão elucidados nas páginas que se seguem. Tal seção se mostra necessária não apenas pela importância de Coleman em nosso estudo, mas também e sobremaneira pela invisibilidade injustificada de tal personagem na historiografia da educação musical.
\end{abstract}

\title{
2. 3 Satis Coleman e a Creative Music
}

No decorrer da pesquisa, a tarefa de escrever sobre a educação musical em meio a Progressive Education parecia confundir-se com a tarefa de escrever sobre Satis Narrona Coleman (1878 - 1961) . Não que seja possível reduzir o domínio ao seu trabalho, no entanto, sua presença se impõe nos materiais de maneira incisiva. Em nosso estudo sobre a revista francesa La Nouvelle Éducation, Coleman figura entre as pessoas mais indicadas, atrás apenas das educadoras que compunham a Guilde des faiseurs et joueurs des pipeaux ${ }^{40}$. Constam também artigos de sua autoria traduzidos para o francês e seus livros estão entre as sugestões de leitura. É ainda digno de nota que, na publicação brasileira que compõe nossa investigação - a Revista Brasileira de Estudos Pedagógicos -, o primeiro texto que tem a educação musical como tema central aborda o trabalho da educadora estadunidense. Trata-se de artigo de jornal assinado por João Caldeira Filho (1945) onde a proposta de Coleman é apresentada como o que de melhor o autor conhecia em matéria de educação musical infantil à época.

Se sua presença nas publicações estrangeiras é exclusivamente positiva, visto que seu trabalho é sempre tomado como exemplar, não seria possível afirmar o mesmo em relação ao que observamos nos volumes selecionados da revista

\footnotetext{
${ }^{40}$ A própria criação da Guilde é baseada no trabalho Margaret James, educadora inglesa influenciada por Coleman, como será abordado no capítulo seguinte.
} 
Progressive Education. A centralidade de seu trabalho é incontestável e parece constituir a maior referência para a área neste cenário por vários motivos. Dentre os autores identificados, Coleman é a segunda que mais contribuiu para a revista, com dois textos originais, uma conferência e uma resenha de livro ${ }^{41}$. Das 57 publicações que compilamos como indicações de leitura, dez são de sua autoria ${ }^{42}$.

Dentre as pessoas apontadas em artigos de outros autores ou nos demais gêneros de textos, Coleman também é a mais presente, somando dez indicações. Seu nome é mobilizado como fundamentação para a prática de outros educadores, mas não apenas, gerando também dissenso sobre alguns aspectos de seu discurso e de sua prática pedagógica experimental. Assim, seu trabalho não guiava de maneira direta a educação musical no cenário, mas era um eixo fundamental para a movimentação de argumentos e experimentos no campo.

É um fato a se observar que seu trabalho seja pouco conhecido atualmente. Em apresentação do primeiro livro da educadora, Stanley Hall (in COLEMAN, 1922) chega a afirmar que este marcaria época em pedagogia musical. Volk (1996) reconhece em Coleman uma precursora do multiculturalismo em educação musical e Southcott (1990) afirma que muitas de suas ideias são pertinentes para além da época em que a educadora estadunidense desempenhou suas atividades. A falta de discussões posteriores sobre o trabalho de Coleman pode ser entendida, segundo Shevock (2015), por um movimento de abandono de visões progressistas no campo da educação musical para um direcionamento mais estético, além de marcar a característica sexista de tal campo. O autor aponta que, mesmo que Coleman seja autora de uma obra de grande importância, a história da educação musical se ocupou preferencialmente de homens, sendo necessário lançar novas luzes sobre mulheres que ainda sofrem com a não-representatividade a partir de uma perspectiva

${ }^{41}$ COLEMAN, Satis. "Creative experience through making musical instruments" In HARTMAN, Gertrude; SHUMAKER, Ann (org.). Creative expression: the development of children in Art, Music, Literature and Dramatics. New York: The John Day Company, 1932, p. $91-98$.

COLEMAN, Satis. "Creative Music" Progressive Education, 1931 b, vol. VIII, p. 333 - 334.

COLEMAN, Satis N. "The progress of the movement for Creative Music". Progressive Education, New York, vol. X, dec. 1932/ jan. 1933, p. 27 -31.

A resenha refere-se ao livro CLARKE, Eric T. Music in everyday life. New York: W. W. Norton \& Co., 1935 e consta no vol. XII, p. 429. Assinada por S. N. C., acreditamos tratar-se de redação de Coleman pois, dentre todos os materiais consultados - todos os números da revista publicados entre os anos de 1925 e 1944, bem como obras aí sugeridas - não encontramos nenhuma outra contribuição relevante para a área que tenha como autor alguém com as mesmas iniciais.

${ }^{42}$ Creative music for children (1922), Creative music for schools (1925), The marimba book (1926), Bells: their history, legends, making and uses (1927), Creative music in the home (1928), First steps in playing and composing (1930), The drum book (1931), The gingfrbread boy and other song (1931), A children's symphony (1931), Your child's music (1939). 
progressista em educação. A presente pesquisa soma esforços para a divulgação e discussão do trabalho da educadora na medida em que a reconhece como personagem fundamental do ensino de música no cenário de renovação escolar da primeira metade do século XX.

A influência percebida nos documentos circunscritos à nossa periodização décadas de 1920, 1930 e 1940 - é resultado e continuação de seus primeiros passos como educadora musical ainda na década de 1910, em um estúdio particular em Washington D. $\mathrm{C}^{43}$ e, posteriormente, em Nova Iorque. Nestes primeiros anos de ensino privado foram gestadas as ideias e os procedimentos didáticos fundamentais do que viria a ser nomeado Creative Music. O título refere-se não apenas a sua proposta, mas também à disciplina que Coleman assume em 1919 na Lincoln School of Teachers College da Columbia University em Nova Iorque.

Segundo Coleman (1932/33), no momento do ingresso na instituição ela tinha como objetivos (a) observar se sua abordagem seria também adequada a grupos mais numerosos, (b) se seria praticável dentro da estrutura de um programa institucional e (c) se as crianças continuariam interessadas ao longo do percurso escolar. É possível concluir que a iniciativa foi bem sucedida, visto que seis anos depois, em 1925, ela assume igualmente a formação de supervisores e professores de música no Teachers College, e permanece desempenhando ambas as funções até o ano de 1942 (VOLK, 1996).

Seu trabalho com as crianças dessa instituição é assim nomeado logo de início por outra professora, segundo a narrativa que Coleman (1932/33) nos oferece de sua trajetória

Durante o primeiro inverno de experimentos na Lincoln School, a professora do sexto ano, vendo como seus alunos eram estimulados ao trabalho original por um impulso interno, disse um dia: "Este tipo de música torna as crianças criativas, então vou chamá-la de creative music a partir de agora". Isso foi em 1919, antes que a expressão creative activity tivesse se tornado um slogan popular (COLEMAN, 1932, p. 28)

\footnotetext{
${ }^{43}$ A própria autora, ao apresentar seu trabalho como uma abordagem experimental, entra em contradição sobre a data exata de início. Em artigo publicado na revista Progressive Education em número de dez. 1932 e jan. 1933, onde expõe uma recapitulação da trajetória com vistas a clarificar possíveis equívocos que a divulgação de sua proposta havia gerado, Coleman afirma que seus primeiros experimentos haviam começado há 17 anos, logo, entre 1915 e 1916 (COLEMAN, 1932/33). Contudo, no livro dedicado a expor a gênese de sua proposta, Coleman afirma que o experimento propriamente dito se inicia em outubro de 1918 (COLEMAN, 1922). O estúdio muda de Washington D. C. para Nova Iorque no ano de 1919 (COLEMAN, 1932/33).
} 
No prefácio ${ }^{44}$ de seu primeiro livro, lançado em 1922, a autora já atribuía a criação do termo à Miss Emily Barnes ${ }^{45}$, que

Depois de observar o experimento em meu estúdio e na escola, ela considerou apropriado o nome Creative Music para cobrir todas as fases do trabalho: a construção de instrumentos, a criação musical e poética, a performance instrumental, o canto e a dança; e é neste sentido que usei o termo ao longo do livro (COLEMAN, 1922, p. ix)

O termo é adotado, então, em ocasião de seu ingresso no corpo docente da Lincoln School e passa a figurar nos títulos de seus livros subsequentes. Mesmo que Coleman (1932/33) tenha declarado, anos mais tarde e depois de críticas, que não estava totalmente de acordo com o título, é assim que ele figura nos documentos que constituem nosso estudo. Com vistas a clarificar sua originalidade e suas contradições, bem como os desacordos gerados no cenário, nos deteremos a seguir sobre alguns pontos fundamentais da Creative Music.

A proposta de Satis Coleman, por mais que constitua uma influência central nos documentos analisados, não pode ser descrita como um método destinado à reprodução. A educadora frequentemente tratava seu trabalho como experimental, não prescritivo. Sua primeira publicação dedicada à apresentação de suas atividades com as crianças - Creative Music for Children, 1922 - já assinalava esta postura e pressupõe que a ação pedagógica é, em grande medida, pessoal

Um relatório detalhado de cada aula ou uma lista de passos seguidos no meu trabalho seria impossível de ser feito nessas páginas, nem mesmo seria necessário. Eu tentei tornar claros minhas crenças e princípios de trabalho, estabelecer meus objetivos, sugerir o material, e expliquei meu plano de uso do material na esperança de que professores e pais que queiram fazer uso prático disso sejam capazes. [...] É impossível dizer para uma verdadeira professora ${ }^{46}$ como ela deve fazer algo, pois cada professora deve ter sua própria técnica. Uma vez que ela adquiriu completamente sua matéria, isso deve estar à disposição de sua sabedoria, das circunstâncias e da natureza e da capacidade da criança (COLEMAN, 1922, p. 207)

\footnotetext{
${ }^{44}$ Assinado em setembro de 1921.

${ }^{45} \mathrm{Na}$ lista de professores publicada em The Lincoln School of Teachers College: A descriptive booklet (COLUMBIA UNIVERSITY, 1922), consta que Emma A. Barnes era a professora do sexto ano, não Emily, como escreve Coleman (1922).

${ }^{46}$ Nos textos da autora, a palavra teacher sempre tem concordância de gênero no feminino.
} 
Anos mais tarde, quando trata da difusão de seu trabalho e de críticas que este vinha recebendo, mais uma vez atenta para o fato de que não criou um copyright system, logo, não teve controle de seus desdobramentos (COLEMAN, 1932/33). Segundo Coleman (1922), a ação pedagógica que segue rigidamente uma sequência fixa de ideias e aulas impossibilita a iniciativa do professor, mesmo que essa série de procedimentos seja de sua própria criação. A autora (1922) sugere, ainda, que a profusão de métodos de ensino de música à época estava ligada à necessidade de manter o interesse das crianças em algo que não era adequado às suas capacidades. $O$ seu trabalho é, antes, "um ponto de vista, uma atitude, uma filosofia", que se centra na educação musical de crianças, mas estaria muito mais comprometida com o seu desenvolvimento integral (COLEMAN, 1932, p. 97 - 98). A Creative Music não é difundida, então, como método a ser adotado, mas a partir de relatos do trabalho de Coleman, referentes, tanto ao período de experimentos em seu estúdio particular em Washington D.C., quanto às aulas na Lincoln School.

Com vistas a expor e discutir os pontos mais importantes de seu trabalho, bem como uma perspectiva de seus desdobramentos, organizamos o texto a seguir em quatro seções. A primeira seção diz respeito aos primeiros experimentos e o início da divulgação de sua abordagem; para tanto, baseamo-nos principalmente no livro Creative Music for Children, publicado em 1922. A segunda seção trata do trabalho desenvolvido na Lincoln School e tem como fonte central o livro A children's symphony, de 1931. A terceira seção apresenta as divergências suscitadas por seu trabalho partindo de críticas e do texto The progress of the movement for creative music, artigo publicado na revista Progressive Education, número de dezembro de 1932 e janeiro de 1933. Por fim, apresenta-se uma seção sobre a aproximação entre a Creative Music e o ambiente familiar, a partir do livro Your child's music, datado de 1939. Decerto, sendo necessário, recorremos à bibliografia secundária ou a demais textos da própria autora. Acreditamos que, a partir de tais temas e obras, é possível perceber a originalidade do trabalho principalmente em dois pontos que nos interessam na presente tese: o estímulo aos processos criativos e à participação das crianças em situações de ensino e aprendizagem.

\section{Creative Music for Children}


Seu primeiro grande relato, como supracitado, intitula-se Creative Music for Children e, apesar de ser lançado em 1922, diz respeito apenas ao trabalho em estúdio. Este livro foi publicado ao mesmo tempo nos Estados Unidos e na Inglaterra, contribuindo para a circulação de suas ideias na Europa, como observado na seção de nosso estudo dedicada à revista francesa La Nouvelle Éducation. Aí se encontram os pilares de sua proposta, tanto no que concerne à didática quanto aos argumentos a favor da educação musical e, mais especificamente, da Creative Music.

O livro é dividido em três partes intituladas, respectivamente, I - O cenário, II - O experimento da creative music e III - O resultado, além de contar com um prefácio da autora e uma apresentação assinada por G. Stanley Hall. A autora trata de vários temas então atuais ligados à educação musical, sobretudo nas partes I e III, demonstrando um grande engajamento para argumentar a favor da área. Na parte II, mais especificamente, Coleman se detém sobre seu trabalho com as crianças, oferecendo detalhes dos procedimentos práticos e dos pressupostos de sua proposta. Nós nos deteremos aqui em três aspectos que julgamos centrais para a compreensão desta proposta tal qual apresentada no livro: a construção de instrumentos, as composições originais e a notação numérica.

\section{Construção de instrumentos}

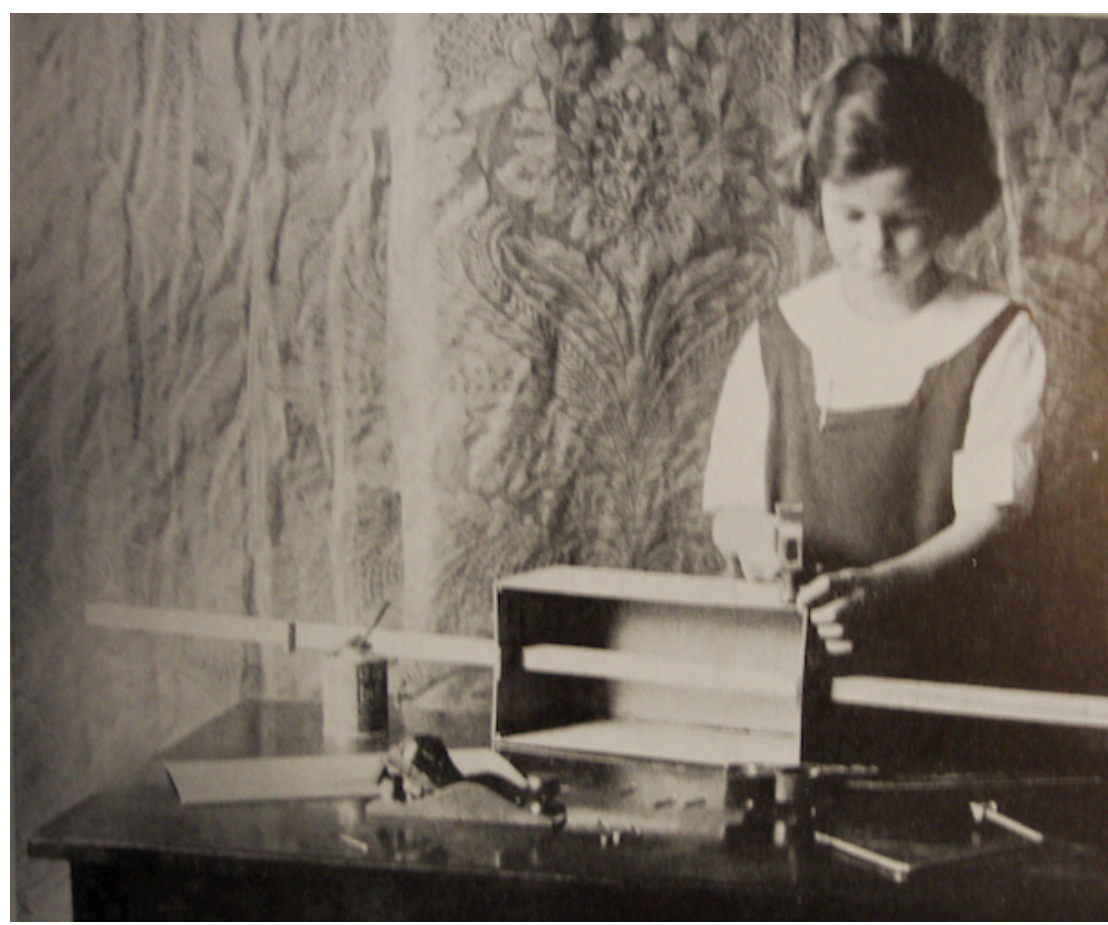

Figura 2 - Alva constrói um violoncelo no Creative Music Studio (COLEMAN, 1922) 
Ao descrever seu experimento, Coleman (1922) precisa que em seu estúdio recebia crianças de três a nove anos de idade, em aulas individuais e em grupo de uma hora de duração. Os encontros aconteciam duas, quatro ou cinco vezes por semana. Em um primeiro momento, o trabalho centrava-se em canções, danças e brincadeiras, sobretudo para as crianças pequenas, entre três e seis anos de idade. No entanto, à medida que essas crianças se tornavam mais envolvidas com as atividades, demonstravam o desejo de tocar as canções que cantavam. Acreditando que os instrumentos tradicionalmente usados para o ensino de música - à época, referia-se diretamente ao piano e ao violino ${ }^{47}$ - não eram adequados a crianças tão pequenas, a educadora decidiu procurar instrumentos mais simples. Por não encontrar nenhum que lhe parecesse adequado, resolveu ela mesma construí-los. Ao fazê-lo, deu-se conta de que as próprias crianças conseguiriam também desempenhar tal atividade.

As crianças de cinco a nove anos de idade passaram, então, a construir instrumentos de percussão, cordas e sopro, enquanto às crianças menores foi possibilitada a prática instrumental. No livro, os instrumentos são apresentados por famílias, porém, na prática, segundo a autora (1922), as crianças poderiam experimentá-los concomitantemente, com a ressalva de que os instrumentos de sopro apresentam maior dificuldade. Ela afirma que "simplicidade era o principal fator para organizar a ordem [dos instrumentos] para as crianças, e não uma lista de categorias ou uma sequência histórica de desenvolvimento" (COLEMAN, 1922, p. 39 - 40).

A inspiração para a construção dos instrumentos vinha de culturas não ocidentais. Isso se liga ao cenário científico do movimento de educação progressista, o qual será abordado adiante, no qual a criança é comparada, por vezes, a alguém primitivo, termo que nos revela uma perspectiva etnocêntrica. Contudo, o trabalho não se restringia à cópia de instrumentos de outras culturas, mas, também, existia espaço para instrumentos inventados ou descobertos pelas próprias crianças. Mesmo

\footnotetext{
${ }^{47}$ A iniciação musical através do piano ou do violino é criticada por Satis Coleman repetidas vezes. Em uma das críticas, lemos que: "Quão ridículo parece agora que tenhamos, durante anos, confrontado a criança com o mais complicado instrumento já desenvolvido pelo ser humano, e esperamos que ela o usasse sem dar-lhe nenhum caminho para atingi-lo! E quão injusto é o veredito de "não musical" que foi dado a tantas crianças incapazes de lidar com este instrumento com destreza! Muitos dos gigantes musicais da Europa viveram antes mesmo da existência do piano! E sei que a maioria destes tocou todos os instrumentos usados em seu tempo. A arte da música é tão antiga quanto a própria humanidade! E ainda hoje, como regra, temos iniciado nossa instrução musical com um instrumento inventado no século XVIII, ou com o violino, o mais difícil de todos os instrumentos modernos!" (COLEMAN, 1922, p. 31)
} 
quando da construção de instrumentos já existentes, estas atividades eram conduzidas de maneira investigativa, com visitas a museus e lidando de maneira experimental com os materiais para a construção.

Diversas vezes, os relatos dos processos de construção mostram uma forte iniciativa das crianças, como quando se inicia a pesquisa sobre instrumentos de sopro e Coleman descreve que "da mesma maneira que eles experimentaram bater em tudo anteriormente, agora eles tentam soprar qualquer coisa que possa ser soprada, e seus experimentos são reveladores" (1922, p.52 - 53). Ou como no relato seguinte, onde uma contribuição é trazida para o estúdio

O hábito de investigar as possibilidades musicais de diferentes objetos mostrou-se quando uma das crianças trouxe para o estúdio uma fúrcula de sua mesa de jantar. Certamente, uma harpa era o instrumento mais adequado ao material. Nós esticamos um elástico estreito e o ajustamos de maneira a afiná-lo, e em poucos minutos uma melodia foi tocada na pequenina harpa de fúrcula. Isso deu às crianças a ideia de algo maior, e uma delas trouxe ao estúdio pequenos galhos de árvores que, sendo bifurcados, tinham a mesma forma que uma fúrcula. Esticando elásticos nestes galhos, eles produziram harpas de fúrcula maiores e mais satisfatórias (COLEMAN, 1922, p. $64-65$ )

A narração das pesquisas das crianças para construção de instrumentos de cordas prossegue e, depois de outras harpas de materiais variados, a autora descrevenos a seguinte situação. Aqui, o conhecimento de acústica é despertado pela atitude exploratória da criança

As crianças se divertiram olhando imagens de músicos tocando harpas egípcias e experimentaram diversas maneiras de segurar a harpa. [...] Ao experimentar posições, uma pequena garota de oito anos que estava sentada no chão com a harpa, fez uma descoberta importante. Ela deixou uma parte da harpa no chão enquanto tocava, e seus olhos arregalaram-se quando ela escutou o som das cordas muito amplificado. Então ela mudou a posição da harpa, ampliando o contato com o chão, e o som foi ainda mais intenso. "Oh, escute! É maravilhoso!" ela exclamou; e todos tiveram que testar. Certamente ela quis encostar a harpa em todas as coisas da sala enquanto tocava, para ver se algo surpreendente aconteceria. Ela experimentou com azulejo, vidro, janela, pedras, cortinas, gesso, parede, espelho, piano, porta e mesas. Ela gostou mais do som junto à porta ou em contato com o piano. Pareceu-lhe que madeiras planas fizeram as cordas soarem mais alto. Então nós discutimos como a madeira capta a vibração das cordas, vibra com elas, e então amplifica o som. Assim eles descobriram o princípio da caixa de ressonância (COLEMAN, 1922, p. 65 - 66) 
O incentivo à postura investigativa não estava circunscrito aos instrumentos presentes no estúdio, mas ultrapassa as atividades do ambiente de ensino. Os dois trechos a seguir são exemplares, posto que descrevem situações em que uma criança descobre e outra inventa um instrumento.

Um dia, Florence trouxe a mim, com muito orgulho, um instrumento que ela descobriu e que não era de sopro, nem cordas ou de percussão. Era um grande cacto espinhoso que cresceu em um vaso da janela de sua mãe. Ela descobriu que os espinhos longos vibravam e soavam musicalmente quando ela os fazia vibrar, e que produziam notas diferentes. Testando-os de maneira cautelosa, ela encontrou três espinhos que se aproximavam das três primeiras notas da escala. Então, orgulhosamente, tocou uma verdadeira melodia para mim no cacto! Que ótima prova de que o mundo mesmo os prados inférteis do oeste - é rico em possibilidades musicais, basta que tenhamos olhos para ver e ouvidos para ouvir! (COLEMAN, 1922, p. 49)

Foi nessa época que uma criança trouxe para mim um instrumento que ela mesma inventou. Este consistia em três colheres de prata de diferentes tamanhos, suspensas por cordas de uma base de madeira. Batendo nessas colheres suspensas, a criança tocou uma melodia para mim (COLEMAN, 1922, p. 44)

Nestes relatos as crianças apresentam um comportamento comprometido com o decurso das atividades, tomando a iniciativa de diferentes maneiras para a construção dos instrumentos, o que depende de uma postura pedagógica específica. Quando tece considerações sobre a prática pedagógica, apesar de não ser muito diretiva, Coleman propõe que a tarefa da professora tem os seguintes pontos fundamentais: "[...] ela deve formular seus objetivos em relação à criança, deve selecionar o material que será usado, deve decidir pelo método ou plano que vai seguir usando o material, e deve trabalhar sua própria técnica ao adaptar seu plano a cada criança" (COLEMAN, 1922, p. 209, grifos no original). O objetivo principal da educação musical seria, independente do contexto, levar as crianças a terem experiências musicais. $\mathrm{O}$ material deve ser adequado às crianças, daí sua busca por instrumentos simples e a frequente oposição ao estudo de piano e violino no início da infância. O método seria uma maneira inteligente de usar o material selecionado. Tanto a seleção quanto o uso do material deveriam ser orientados por um princípio, neste caso específico, o learning by doing. A técnica, por fim, deve ser desenvolvida 
de maneira particular, pois depende tanto da personalidade da professora, seu histórico e habilidades, quanto das próprias crianças, visto que responsiva.

Para Coleman, a construção de instrumentos adequados e a prática instrumental eram fundamentais para uma educação musical comprometida com a promoção de experiências para as crianças e guiada pelo learning by doing. Mais do que uma escolha ou preferência da educadora, essa abordagem era vista como condição para o desenvolvimento musical das crianças pequenas, como afirma nos seguintes trechos:

O desenvolvimento real de alguém sempre vem de sua experiência. Experiências musicais são essenciais para o crescimento musical. Aqueles de nós que meramente escutam não são musicais; nós temos que manusear os materiais e fazer, nós mesmos, os sons para sermos musicais. Contudo, certamente, enquanto o piano e violino forem os únicos instrumentos que ensinamos na infância, as crianças muito pequenas - com exceção das especialmente dotadas - deverão permanecer excluídas da experiência instrumental e olharão com olhos carentes e famintos. Ou ainda, tentarão tocar e terão resultados infelizes (COLEMAN, 1922, p. 151)

Uma vez que ela deve inventar para se realizar, ela deve manter uma atitude prática e inventiva. Enquanto ela sente seu caminho através da Ciência da Música, testando e aplicando o que ela descobre, fazendo experimentos de Acústica, ela deve manter uma atitude experimental; e reconhecendo a abertura um novo mundo de possibilidades, ela aprende fazendo [learns by doing] e por pensamento definido. Seus pensamentos tomam formas visíveis em seus instrumentos e ela pode testar sua validade de maneira impessoal. As satisfações da realização são o motor para a ação futura (COLEMAN, 1922, p. 149, grifo no original)

O emprego de termos como learning by doing e experiência nos remete à filosofia da educação de John Dewey, cuja centralidade no cenário sobre o qual nos debruçamos é evidente. A influência de Dewey não se limita a sua profusa contribuição como autor, mas somam-se à difusão de sua produção teórica a sua atuação como professor de filosofia da educação no Teachers College da Columbia University entre 1905 e 1930; seus experimentos educativos precedentes, entre 1896 e 1904, junto a sua esposa Alice Dewey e outros profissionais na escola laboratório da Chicago University; bem como sua associação ao movimento Progressive Education.

Os eventos supracitados nos quais as crianças são protagonistas das atividades de construção de instrumentos - sobretudo aquele em que a criança aprofunda seu entendimento de acústica através da exploração de várias maneiras de segurar a harpa 
- servem-nos como exemplos de uma educação musical orientada pelo princípio do learning by doing. Sobre o termo experiência, Southcott (2009) afirma que este é mobilizado por Coleman desde seus primeiros escritos a partir de uma perspectiva deweyana. Ao trabalhar sobre o conceito de experiência educativa em Dewey, Branco (2010) aponta duas características fundamentais da mesma: a continuidade e a interação. A primeira traduziria um aspecto temporal, visto que uma experiência educativa sempre se funda em experiências precedentes e condiciona as subsequentes, na medida em que condiciona atitudes e funda condições de continuidade. A interação, por sua vez, traduz um aspecto espacial, pois diz respeito às relações entre o organismo e o meio que o circunda. Outro aspecto importante segundo Branco (2010) é o fato de que a experiência é resultado de uma combinação entre atividade e passividade. A criança, em um processo educativo, faz uma experiência e sofre as consequências dessa, de modo que atividade e mudança necessitam ser refletidas. Alix (2017), ao dedicar-se à experiência educativa em Dewey, chama atenção para o caráter de continuidade no que este apresenta de conectivo entre as experiências das crianças e as experiências da humanidade. Segundo o autor (2017), na teoria deweyana, as experiências individuais das crianças e aquelas acumuladas na cultura social tal qual se apresentam no programa escolar são pontos de um mesmo processo contínuo de civilização.

Voltando à reconstrução conceitual de Branco (2010), a autora afirma que uma experiência educativa pode ser assim considerada de acordo com a qualidade da continuidade e da interação alcançadas. Afirma ainda que

[...] o erro da concepção tradicional de educação não reside no focar-se na preparação para o futuro (essa preparação é igualmente inerente à concepção da educação como crescimento, enquanto neste se intersectam presente e futuro), mas em ignorar as potencialidades do momento presente como catalisador das energias da aprendizagem (BRANCO, 2010, p. 602)

Acreditamos ser possível observar tais aspectos da experiência educativa em um exemplo apresentado por Coleman na seção dedicada à construção de instrumentos de cordas friccionadas. A educadora relata a iniciativa da primeira criança a construir um instrumento desta família a ser tocado como violino - até então, para facilitar o uso dos instrumentos, esses eram sempre tocados no colo ou entre as pernas, como violoncelos. Elizabeth, cuja idade não é informada, decide 
voluntariamente construir um violino e o faz, instruída pela educadora. Ao corpo do instrumento são adicionadas apenas três cordas, como aos anteriores, com vistas a evitar dificuldades. A facilidade de manipulação do arco para tocar o instrumento, agora menor e em uma nova posição, surpreendeu a educadora e, como ápice da empreitada bem-sucedida na narração de Coleman, temos que "depois de Elizabeth ter testado seu novo violino e ter tocado algumas melodias, ela espontaneamente o abraçou, dizendo "Oh, eu realmente amo este pequeno violino!". O violino era verdadeiramente dela, pois ela o fez" (COLEMAN, 1922, p. 77).

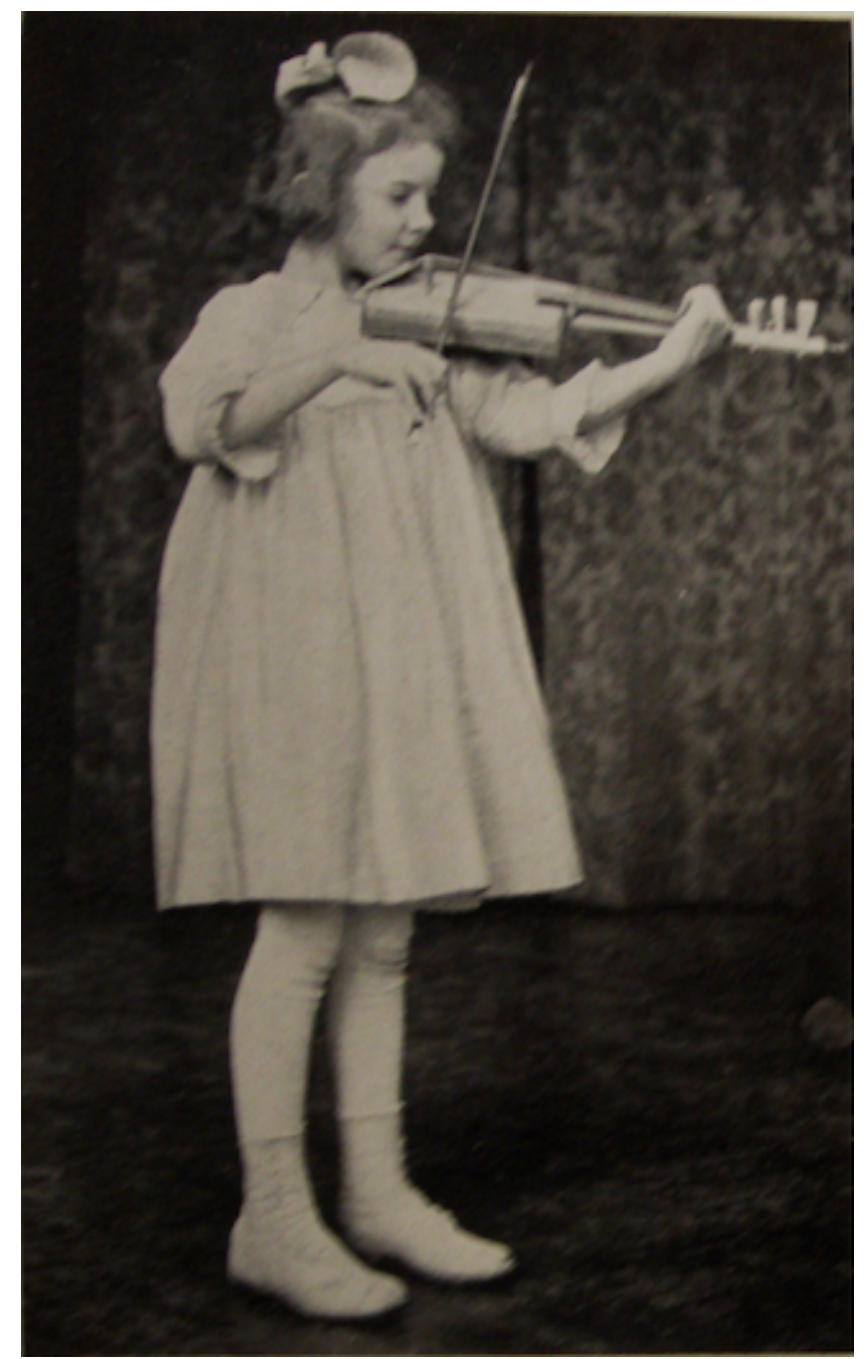

Figura 3 - Elizabeth ao violino, logo depois de finalizar a construção do instrumento e tentando ajustar, por si mesma, seu braço esquerdo à nova posição (COLEMAN, 1922)

O violino construído por Elizabeth serviu de modelo para outras crianças e, depois de alguns instrumentos construídos, a educadora relata que as crianças começaram a fazer música de câmara, cujo repertório incluía composições originais. 
Depois de alguns meses usando o violino que construiu, Elizabeth ganhou um violino "de verdade". No trecho seguinte, a educadora discorre sobre a importância desse momento e sua relação com a experiência anterior

\begin{abstract}
Depois de alguns meses de uso de um violino artesanal, Papai Noel trouxe para Elizabeth um violino "de verdade", e esse foi um ponto importante de seu desenvolvimento musical. Ela agora possuía um violino de fabricação profissional em suas mãos pela primeira vez na vida, e ele parecia um velho amigo muito próximo. Ela não apenas sabia os motivos de cada pequeno detalhe de sua construção, como também estava apta a apreciar todas as vantagens deste em relação ao seu instrumento rudimentar: seu polimento fino, suas curvas graciosas e, principalmente, as laterais cavadas onde o arco poderia correr livremente. $\mathrm{O}$ instrumento adequou-se naturalmente sob seu queixo e quando ela passou o arco pelas cordas pela primeira vez, ela estava consciente da riqueza sonora que ela não era apta a produzir até então, e se maravilhou com as habilidades de um luthier profissional. Ela possuía uma carga de conhecimento e experiência que a permitia apreciar de uma só vez a riqueza de timbre e as e as grande possibilidades musicais, e discriminar entre suas próprias notas boas ou más. Mesmo que apenas um bom violino "de verdade" e bem fabricado possa agora atender às suas necessidades musicais, ela ainda guarda afeição pelo objeto que ela mesma construiu - seu primeiro pequeno violino (COLEMAN, 1922 , p. $78-79)$
\end{abstract}

A construção de um violino neste caso é significativa na medida em que é um desdobramento de experiências anteriores - ela decide construí-lo depois de um período em que o grupo se dedicava aos instrumentos da mesma família, porém maiores e tocados em outra posição -, um desdobramento que se apresenta como desafio e enriquece o que já vinha sendo feito até então, conferindo continuidade. A existência de um novo instrumento da família possibilita uma nova qualidade de interação entre as crianças, impelidas a uma prática instrumental em grupo também nova para elas. Por fim, o fato de ter passado pela experiência de construção a permite aceder a uma relação mais complexa e informada quando apresentada ao instrumento profissional. A experiência anterior funda uma relação também em continuidade com as experiências acumuladas socialmente. Elizabeth é apresentada a um objeto de cultura por um processo no qual apropria-se do mesmo, compreendendo suas qualidades e algumas das razões que o determinam.

Este exemplo mostra-se ainda mais interessante se pensarmos que o uso do violino na infância é, por vezes, condenado por Coleman. Isso comprova que suas considerações sobre a prática instrumental na infância não são asserções rígidas a 
serem seguidas indiscriminadamente. $\mathrm{O}$ uso do violino como relatado neste caso foi um processo de construção de conhecimentos musicais e de habilidades motoras a partir de uma relação guiada pela professora juntamente a uma postura de engajamento da criança, o que muito difere do ensino que a educadora denunciava como "tradicional".

A relação de Elizabeth com o violino leva-nos, ainda, ao próximo ponto fundamental da Creative Music e fundamental também para a presente tese. Dentre as composições feitas pelas crianças, encontramos uma assinada pela menina e intitulada "Uma dança para o novo violino". O estímulo às práticas criativas é o ponto sobre o qual nos debruçaremos a seguir.

\section{Composições originais}

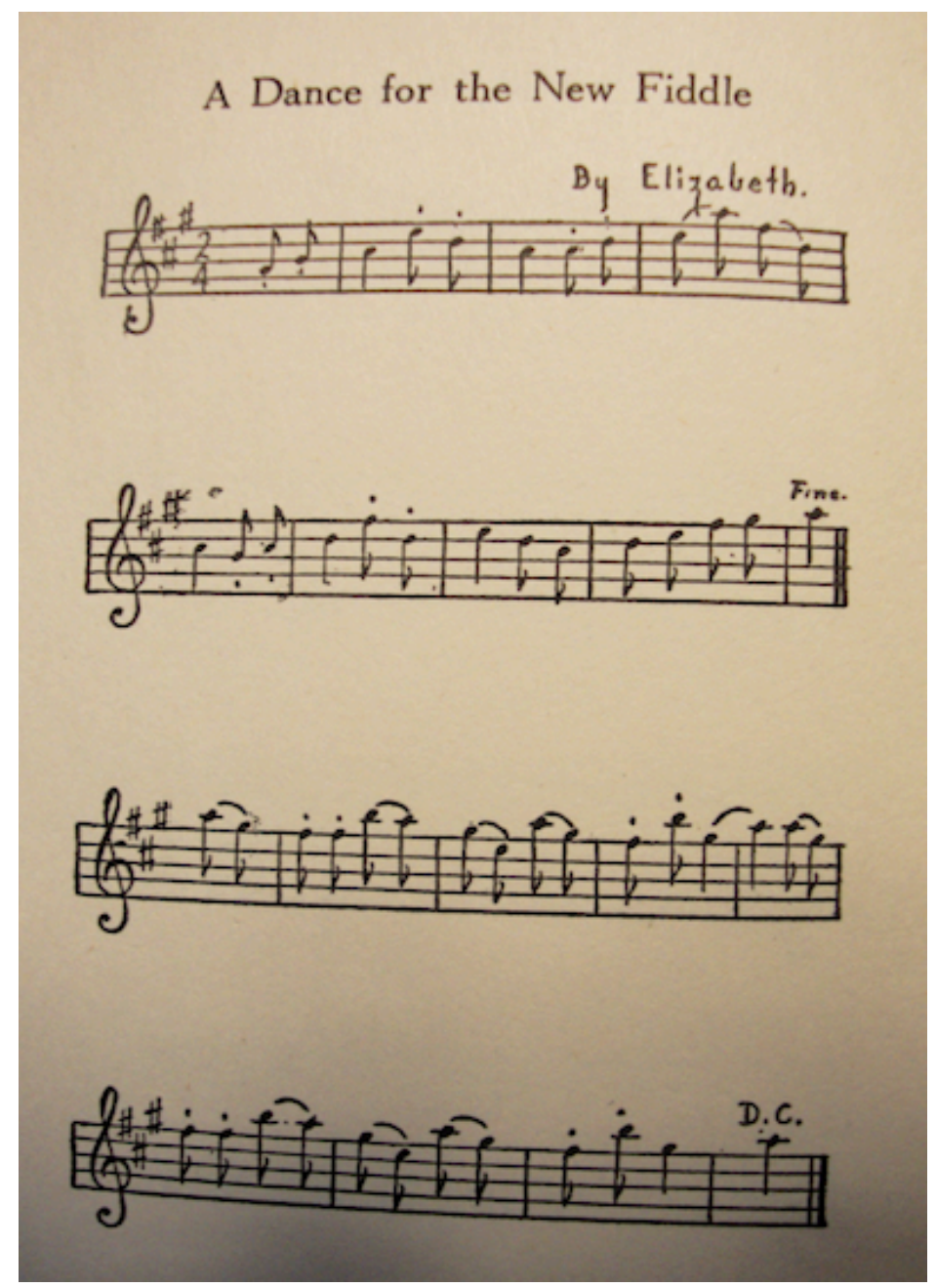

Figura 4 - Uma dança para o novo violino de Elizabeth (COLEMAN, 1922) 
A construção de instrumentos parece ser a característica predominante da Creative Music quando esta é apresentada nas publicações francesas ou brasileira. A originalidade da abordagem que congrega música e trabalho manual provoca ressonância, seja de maneira entusiasta, como quando os educadores são convidados a exibir instrumentos feitos pelas crianças em exposições da associação La Nouvelle Éducation; seja com admiração comedida, quando Caldeira Filho (1945) reconhece que a atividade é interessante porém, ao apresentar trabalhos de educação musical no Brasil, assume que levar as crianças a construírem instrumentos envolveria muitos esforços e condições nem sempre disponíveis.

Apesar do traço fundamental da divulgação do trabalho de Coleman ser a construção de instrumentos, a abertura para o envolvimento das crianças não se restringia às atividades desta natureza quando examinamos sua produção. Uma esfera de seu trabalho estreitamente ligada à nossa tese é a valorização das criações musicais das crianças. Com os instrumentos adequados em mãos, as crianças continuam em um ambiente guiado por uma postura experimental e, tratando-se de prática musical, não poderiam apenas reproduzir repertório. A primeira evidência de tal valorização é o fato de um capítulo de seu primeiro livro ser dedicado ao assunto, intitulado Composições Originais. A própria autora afirma que

[...] compor tem sido uma atividade definitivamente estabelecida em cada fase do trabalho. Acredito que a habilidade do pensamento e da ação original é melhor incentivada nos primeiros estágios de qualquer forma de expressão, pois após o estabelecimento completo de hábitos de seguir linhas convencionais, torna-se muito difícil para uma pessoa comum mudar de conduta em direção a caminhos novos (COLEMAN, 1922, p. 122)

Mais do que em seu discurso, a valorização das composições das crianças evidencia-se com a apresentação dos programas (tab. 3 e 4) de dois concertos ocorridos no estúdio nos anos de 1920 e 1921. Esses eventos tinham como público as famílias e amigos e, nas edições cujos programas são aqui reproduzidos, todas as peças foram compostas e tocadas pelas crianças.

Programa de Composições Originais

22 de maio de 1920 


\begin{tabular}{|c|}
\hline Creative Music Studio, Nova Iorque \\
\hline SOPROS \\
\hline *A Woodland Melody (flautas de pã) \\
\hline The Wind among the Reeds (flauta chinesa) .............................................. Elizabeth \\
\hline A Summer Song (flageolet) \\
\hline 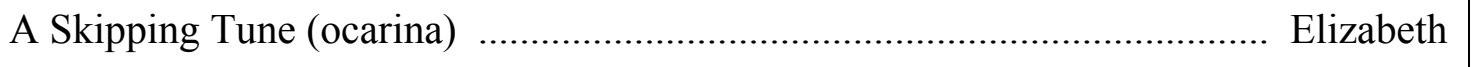 \\
\hline The Bird's Concert (ocarinas) ................................ \\
\hline tocada pela classe \\
\hline Little Bo-Peep (dois flageolets) ............................................... composto por Elizabeth \\
\hline tocada por Elizabeth e Florence \\
\hline PERCUSSÃO \\
\hline Sunday Morning (para Vibrating Rods) .... \\
\hline Improvisation (gongo chinês) .................... \\
\hline 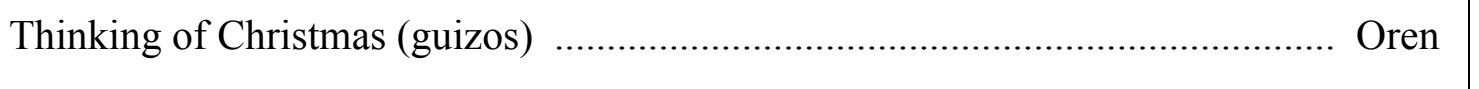 \\
\hline 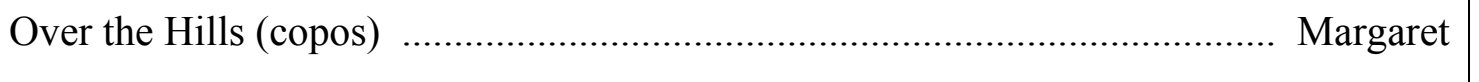 \\
\hline 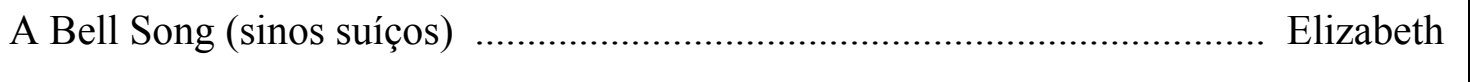 \\
\hline *The voice of Spring (marimba) ............................. \\
\hline A Crystal Chorus (copos) ...................................... \\
\hline tocada pela classe \\
\hline CORDAS \\
\hline A Chinese Story (qin) ........................ \\
\hline A Monkey Song (banjo de coco) .... \\
\hline *Happy Thoughts (alaúde) ................................. \\
\hline 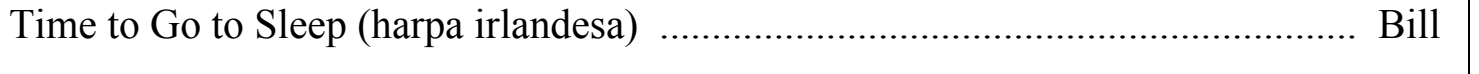 \\
\hline 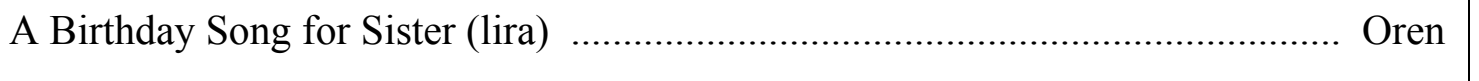 \\
\hline $\begin{array}{r}\text { tocada pela classe } \\
\text { tomposta por Florence }\end{array}$ \\
\hline *Just a Plain Song $($ fiddle $)$........................... \\
\hline *Once Long Ago (monocórdio) ................................................................... Florence \\
\hline *In the Evening (violino) ................................. \\
\hline *The Wreck of the Hesperus (violoncelo) \\
\hline
\end{tabular}




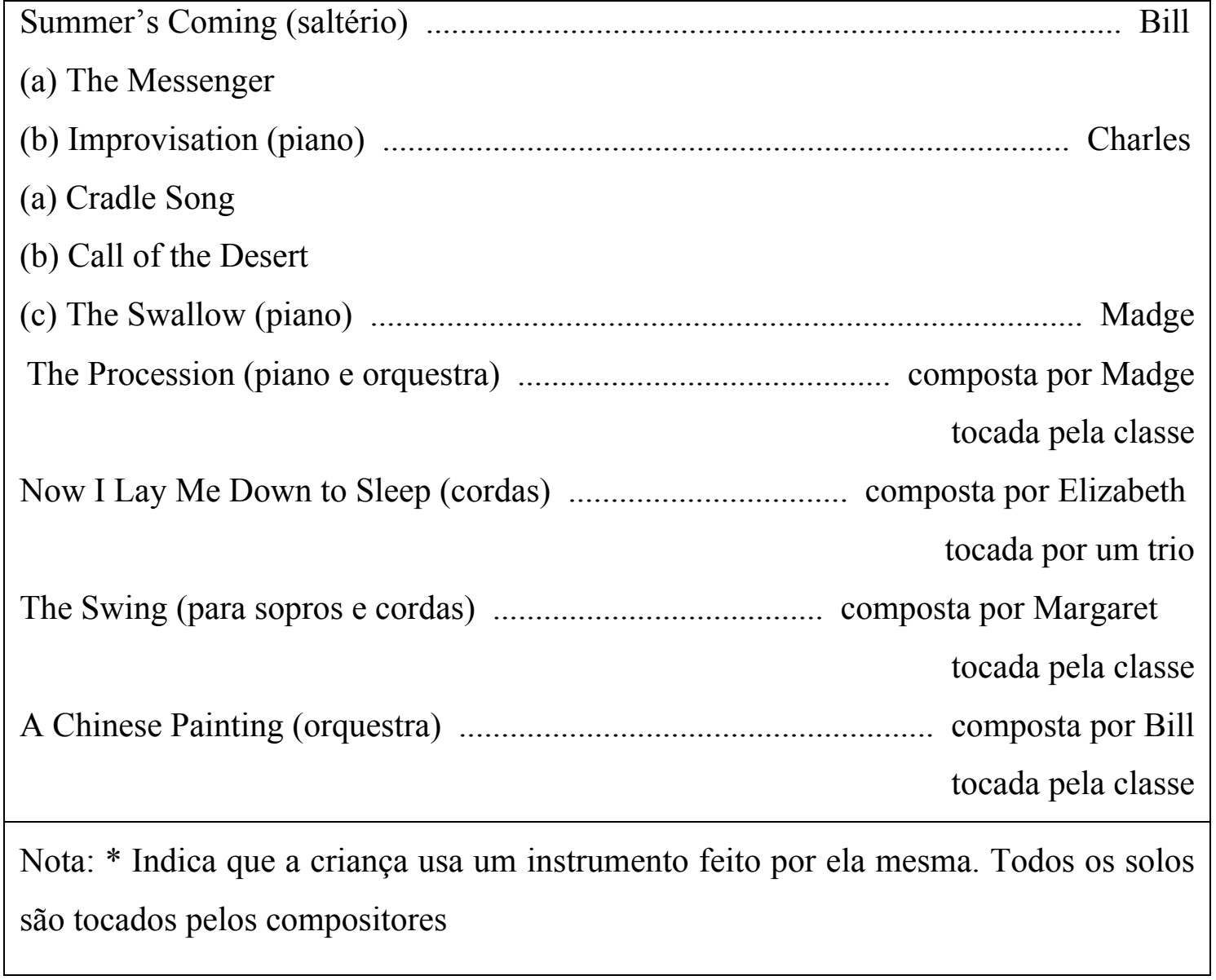

Tabela 3 - Programa de concerto (COLEMAN, 1922, p.130 - 131)

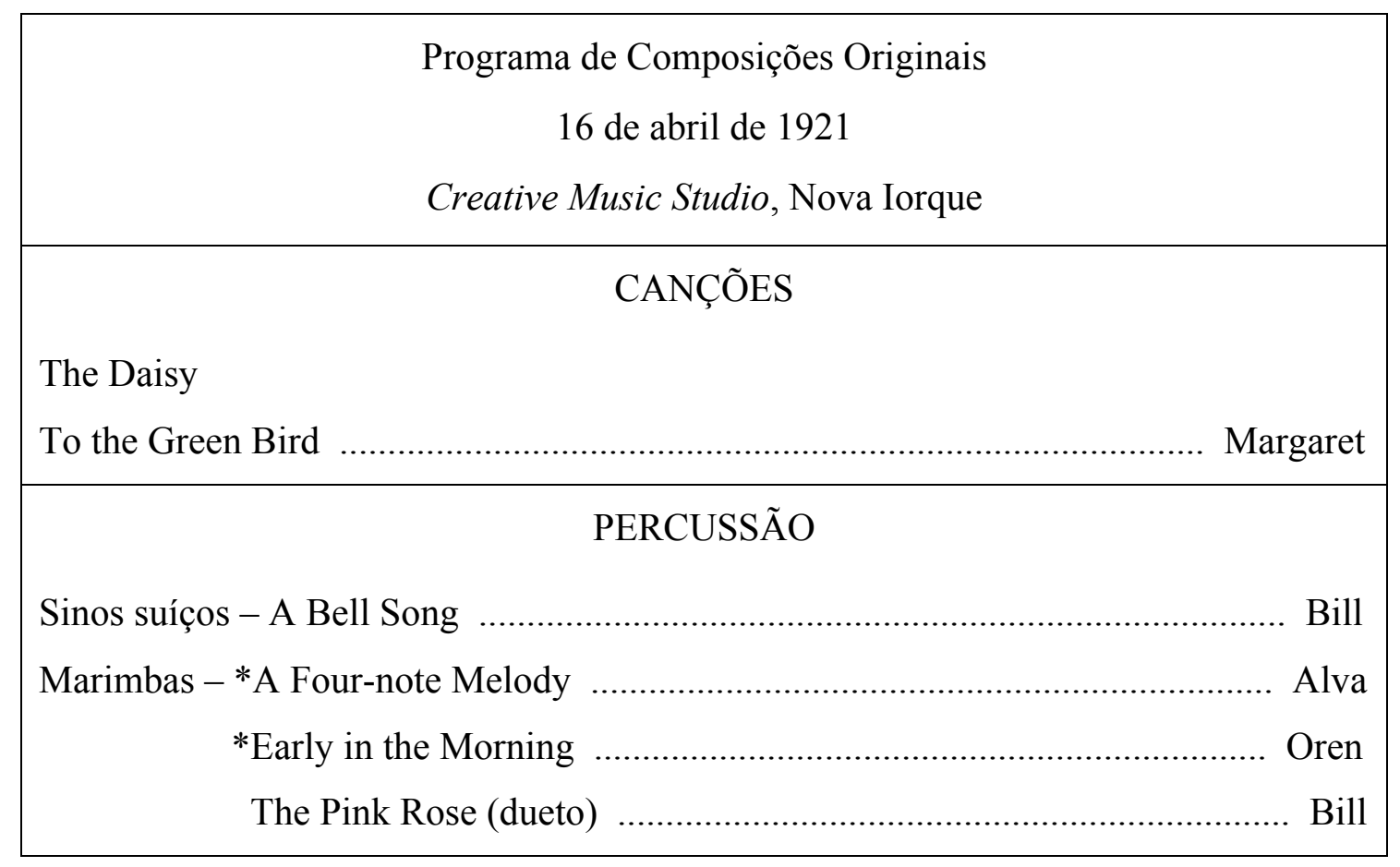




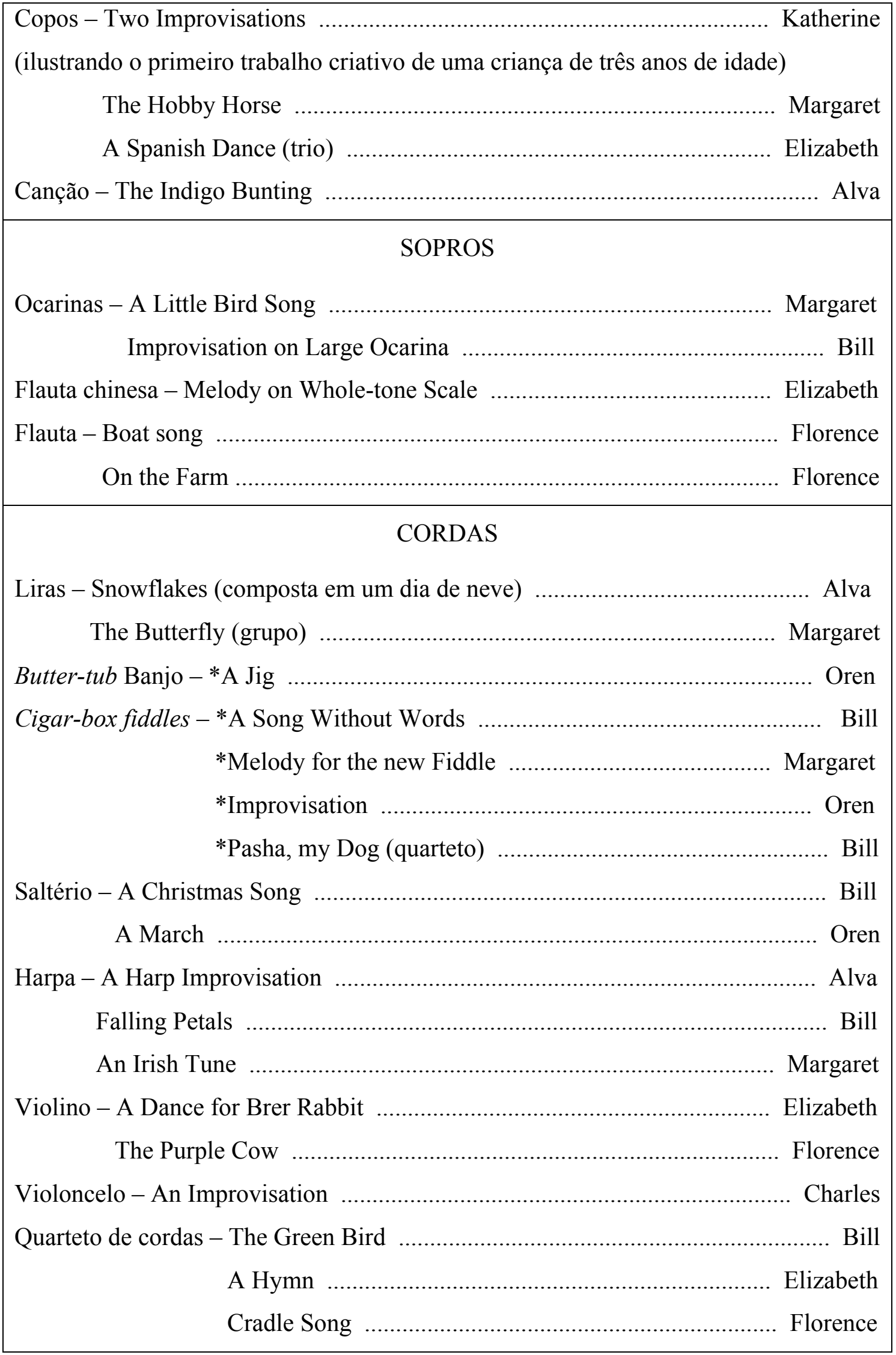


Nota: * Indica que a criança usa um instrumento feito por ela mesma. Apenas os compositores são indicados, embora algumas peças sejam tocadas por mais de uma criança.

Tabela 4 - Programa de concerto (COLEMAN, 1922, p. 132 - 133)

Além dos programas, Coleman apresenta também algumas melodias compostas por seus alunos e alunas. Estes exemplos, se somados à citação precedente, nos confirmam que as práticas criativas das crianças eram um aspecto de grande relevância na proposta, o que é fundamental para nossa tese. Passamos, então, a algumas observações sobre como a educadora aborda o tema neste livro.

É de se notar que o título do capítulo, assim como o subtítulo do trecho em que a autora retoma alguns temas em uma seção da terceira parte, sejam ambos Composições Originais. Atentamos para a escolha do termo Composições - e não, por exemplo, Criações -, pois reflete algo específico da proposta. $\mathrm{Na}$ defesa da importância dos processos criativos, as modalidades de improvisação e composição têm suas particularidades e, parece-nos, a segunda ocupa posição de maior destaque.

A improvisação aparece como prática ligada principalmente ao início da infância. Coleman (1922, p. 176) afirma que, "para as crianças muito pequenas, improvisar é muito mais fácil que aprender uma dada melodia" e que "todas as crianças amam fazer isso". É interessante observar que, no programa do concerto de 16 de abril de 1921 apresentado anteriormente, constam "Dois Improvisos" atribuídos a Katherine. Existem ainda outras peças de nomeação similar, no entanto, essa é a única que conta com a seguinte observação: "ilustrando o primeiro trabalho criativo de uma criança de três anos de idade" (COLEMAN, 1922, p. 132). Isso nos sugere que esta prática tem especificidades quando se trata dos primeiros anos. Em outro trecho, lemos que

Frequentemente as crianças empregavam mais de uma forma de improvisação ao mesmo tempo, como a letra e a melodia de uma canção. Bill começou suas aulas aos três anos de idade. Suas primeiras improvisações em canção e em dança eram sem forma, expressão infantil, natural a toda criança de sua idade (COLEMAN, 1922, p. 128) 
Assim, temos um passo que nos parece fundamental à época para a aceitação de formas de expressão de crianças muito pequenas, reconhecendo-as em sua particularidade. Isso parece evidente na medida em que a idade da criança é indicada como justificativa para as características de sua produção nos exemplos supracitados.

Ainda ao defender a prática de improvisação como conveniente à infância, Coleman nega que esta seria exclusividade de pessoas naturalmente inclinadas. Para negar o senso comum, a autora defende a improvisação como hábito a ser fomentado.

[...] acredito que a improvisação, assim como o canto e outras habilidades que muitas pessoas consideram dons especiais, são o resultado de hábitos cultivados desde cedo; e a criança que começa a improvisar canções, danças e melodias instrumentais já nos primeiros estágios de seu desenvolvimento musical, crescerá naturalmente nesta direção, como uma flor que vai em direção ao sol, porque a alegria que ela experimenta com o trabalho original é o estímulo necessário. E isso não é difícil quando se inicia no início natural (COLEMAN, 1922, p. 175 - 176)

No entanto, para tal defesa, a autora se vale de uma imagem de educação como processo de crescimento natural, no qual a satisfação individual bastaria para a motivação na continuidade do processo. $\mathrm{O}$ uso de léxico e a construção de imagens que remetem à natureza podem ser compreendidos, no cenário escolanovista, de acordo com duas tendências: o viés científico-biológico em considerações sobre a infância e a herança do pensamento rousseauniano.

Para Alix (2017), a Progressive Education é parte de um movimento internacional e, nos Estados Unidos, a busca por uma instituição escolar progressista se baseia tanto em ideias pedagógicas importadas da Europa - dentre as quais, aquelas de Rousseau que advogam por uma educação em conformidade com a natureza são de grande importância - quanto no paradigma evolucionista que conferia legitimidade científica. Os debates neste país estavam orientados sobretudo por essas duas vertentes, seja de maneira a concordar ou divergir parcialmente de tais pressupostos, e deram origem a distintas interpretações pedagógicas, porém sempre defendendo uma educação orientada pela atividade da criança.

Monarcha (2009), em um dos momentos de seu trabalho sobre as ideias escolanovistas no Brasil, faz um apurado exame das condições internacionais dos movimentos assim orientados. $\mathrm{O}$ autor aponta para a ambivalência do impulso para a produção de estudos científicos de viés positivista sobre a infância no início do século 
XX, que acabam mesmo por ocasionar a popularização de testes classificatórios de inteligência, e a forte carga nostálgica romântica que atribui à natureza a imagem de “melhor educadora" (MONARCHA, 2009, p. 45). Nas palavras do autor, o momento altamente contraditório pode ser assim compreendido:

[...] entre o final do século XIX e as primeiras décadas do século $X X$, a cultura psicopedagógica nomeada vagamente de "educação nova" ou "escola ativa" ou ainda "escola nova", uma cultura assentada na compreensão do entrejogo do organismo e o meio circundante, armou-se com o rigor epistemológico próprio da ciência analítica, ou seja, observação dos fatos, manejo do método experimental, quantificação e generalização da experiência. Num futuro não muito distante, essa cultura culminará com a organização de um funcionalismo biológico e uma antropologia naturalista, ambos perigosamente exacerbados (MONARCHA, 2009, p. 32)

Monarcha chega a sugerir que a caracterização majoritária deste cenário como palco de uma revolução copernicana na educação, onde a criança teria passado ao centro da escola, não é exatamente verdadeiro. Para ele (MONARCHA, 2009, p. 46), “o verdadeiro centro, o centro de fato, não é a criança e seu ensino, mas a psicologia funcionalista, a ela e somente cabem todas as honras e glórias".

Ainda sobre a tensão entre uma ideia de educação natural e o entusiasmo científico, Cousinet (1968) nos apresenta duas considerações que julgamos pertinentes. Em relação ao avanço dos estudos concernentes à área da psicologia infantil, o autor atenta para o fato de que a educação nova não poderia ser simplesmente sua subordinada, reduzindo-se a uma "psicologia da infância aplicada" (COUSINET, 1968, p. 16, grifo no original). A pedagogia, ao contrário de uma ciência descritiva e de observação, tem um caráter prescritivo e, mesmo quando pretende basear-se em uma ideia de condução de acordo com a natureza da criança, o faz submetendo-a a princípios e necessidades condizentes com a sociedade da qual faz parte. Em relação à herança rousseauniana, Cousinet a percebe como determinante dos movimentos escolanovistas, porém, atenta para o seguinte fato: na obra cujas ideias subjazem ao cenário estudado - a saber: Emílio, ou da Educação -, tanto Emílio quanto seu preceptor são personagens fictícios. Assim, as proposições de uma educação natural rousseauniana são arbitrárias e, para Cousinet (1968), a liberdade atribuída ao educando encontra resistência em projetos reais de educação, sobretudo institucionais. 
Em sua proposta, Coleman, ao mesmo tempo em que reconhece as especificidades da expressão de crianças pequenas e a isso relaciona a prática da improvisação musical, também atribui a essa prática uma função muito específica no processo educacional. A improvisação com crianças pequenas passa rapidamente, ao longo do crescimento dessas, a ser apenas uma etapa para a composição. A imagem do desenvolvimento como um processo tão natural quanto a inclinação da flor que busca a luz solar parece ter valor de figura retórica quando nos dedicamos aos seus relatos dos processos criativos orientados à composição.

Apesar de legitimar a improvisação sem forma das crianças no início do trabalho e de se contrapor ao senso comum que limita as atividades criativas àqueles previamente inclinados - o que julgamos altamente positivo em um quadro de educação comprometida com as crianças e de caráter democrático -, Coleman apresenta os exemplos de composições de seus alunos e alunas como resultados naturais de um ambiente em que podem se expressar livremente. Em suas palavras: “esses exemplos não são apresentados como evidências de precocidade ou habilidade extraordinária, mas simplesmente como a expressão natural de crianças em condições que as oportunizam a livre expressão" (COLEMAN, 1922, p. 123).

Os processos criativos, no entanto, não são tão naturais ou livres quanto podem parecer. Ao menos no trecho em que a educadora nos apresenta um percurso didático, este parte da etapa na qual se deve deixar a criança tocar livremente para, através das etapas intermediárias - fazê-la consciente das melodias tocadas e de suas formas expressivas - , ajudá-la a lembrar-se de suas composições. Ou seja, em tal percurso, a improvisação é o passo inicial para a realização de um produto específico. Coleman reconhece que, em um primeiro momento, as crianças não lembram facilmente do que executaram, mas toma essa característica como uma dificuldade a ser superada por meio de exercícios. Estes consistem na limitação à improvisação de frases tão curtas quanto for possível à criança memorizar, para reproduzi-las na sequência de sua invenção. Com a combinação destas frases, então, chega-se à composição. Nas palavras de Coleman:

Por exemplo, uma criança improvisaria uma frase e a ela seria pedido que a repita perfeitamente. Se ela não consegue fazer isso, ela deve tentar frases cada vez mais curtas, até que consiga lembrarse da frase perfeitamente. Então, uma segunda frase e sua repetição, e a combinação das duas frases; e assim sucessivamente até a composição (COLEMAN, 1922, p. 126) 
O procedimento descrito acima, certamente, fomenta a organização do impulso criativo das crianças de maneira a resultar em composições. Os exemplos nos mostram que algumas criações são canções, referindo-se a experiências vividas pelas crianças, como a observação de passarinhos ou de um vaso de flores. Para este gênero a educadora não oferece procedimentos didáticos, apenas relata que, de início, ela mesma canta frases improvisadas em meio às conversas com as crianças, com o intuito de incentivá-las a começarem a improvisar. No entanto, o recurso literário, seja pré-existente ou fruto de invenção, é especialmente bem estruturado com versos e rimas. Há também melodias compostas diretamente nos instrumentos, às quais são adicionadas letras ou não. Salientamos, contudo, apenas que a improvisação passa rapidamente à função de etapa composicional, e que o processo, como acima descrito, mesmo que levando em consideração a ação da criança, é fruto de orientação pedagógica de um adulto, claramente estruturado, a despeito de toda a retórica apoiada em uma pretensa naturalidade.

A acentuada atenção à manutenção de produtos dos esforços criativos das crianças não significa, entretanto, uma mudança de foco. Coleman sustenta que "a compensação da professora é ver o efeito na criança, não na beleza intrínseca do que foi criado" (COLEMAN, 1922, p. 209, grifo no original). Na proposta em questão, a condução da atividade de improvisação visa a torná-la refletida e, para tanto, mostrase condizente com uma ideia de música como obra. Podemos, ainda, sugerir que a ideia de educação centrada na atividade das crianças acaba por acompanhar uma necessidade de desdobramento material cujo resultado é a produção de objetos. As crianças, em uma educação musical ativa, são construtoras tanto de seus instrumentos quanto de suas músicas.

À necessidade de orientar as atividades criativas para a manutenção de um produto, a composição, soma-se a necessidade de meios para tal fim. Uma composição não o é senão registrada, e aqui se apresenta mais um traço constitutivo da proposta de Coleman, sobre o qual nos detemos a seguir: a notação numérica.

\section{Notação}

Na primeira parte do livro, como preâmbulo à apresentação de seu trabalho, Coleman discorre sobre alguns assuntos, dentre os quais encontramos suas primeiras 
experiências musicais ainda na infância. Vem deste período não apenas o interesse pela área, mas também o descontentamento com um determinado modo de seu ensino. A autora narra seu primeiro curso de piano como episódio frustrante, aos oito anos de idade, e isso se deve sobretudo à primazia atribuída à notação. Desde a primeira aula a prática instrumental estava subordinada à decodificação de partituras e, mesmo que de maneira independente, ela estava desautorizada a "tocar de ouvido" pois, segundo sua professora, isso atrapalharia sua aprendizagem da leitura. Coleman relata que, depois de um ano de aulas, desistiu do curso e passou a tocar livremente. Os anos seguintes foram de desenvolvimento musical livre e autônomo. Segundo ela (1922), as memórias dessa trajetória a fizeram experimentar, quando adulta, ensinar música sem começar pela notação.

$\mathrm{Na}$ condição de educadora, então, Coleman opera a inversão cuja necessidade percebeu já na infância. Ela começa a ensinar música por imitação, de ouvido, por atividades de improvisação, adiando o ensino da leitura e da escrita de partituras para o momento em que essas se fizessem necessárias. Em suas palavras, quando do início da descrição de seu trabalho: “[...] e sobre a notação? Eu lhes ofereci a notação quando, pelas suas próprias experiências, eles perceberam a necessidade de aprender a ler as notas, desejaram e pediram isso" (COLEMAN, 1922, p. 21).

Como justificativa para operar essa inversão, Coleman recorre à comparação com a língua. Segundo ela (1922), da mesma maneira que as crianças aprendem a falar antes de aprenderem a ler e escrever, assim também deveria ser em música. Elas deveriam ter a liberdade de se expressarem musicalmente, seja pelo canto ou pela prática instrumental, antes de dominarem conhecimentos de notação.

Assim, na Creative Music, a notação aparece como ferramenta para o fazer musical. A partitura, para Coleman, não poderia ser confundida com a própria música, ou seja, não era por si mesma objeto da educação musical. Para sustentar essa posição, ela recorre a um dos autores que, segundo Southcott (2009), é primordial na composição de suas referências:

Herbert Spencer nos lembrou, anos atrás, que a coisa deve ser ensinada antes de seu símbolo - que a experiência deve vir antes do conhecimento -, mas nós temos sido lentos em perceber quão impiedosamente temos rompido com este princípio em nosso ensino de música. Nós esquecemos a finalidade original e verdadeira da notação, e confundimos o símbolo com a coisa simbolizada (COLEMAN, 1922, p. 16, grifos no original) 
A denúncia do foco na notação como prejudicial nos sistemas de educação aponta, por conseguinte, a incapacidade destes para promover a expressão musical das crianças. Para Coleman (1922), a expressão musical não poderia ser impedida por obstáculos de grande dificuldade física ou mental. A busca por instrumentos adequados à infância partia dessa premissa, bem como a reavaliação do papel legado à notação nos processos de ensino e aprendizagem.

De acordo com a importância atribuída aos processos criativos, como já observado, sublinhamos que daí deriva a necessidade de um sistema de escrita. Visto que desde muito pequenas as crianças eram levadas a compor, logo eram igualmente levadas a anotar suas composições. Não apenas para lembrarem do que inventaram em outro momento, mas também porque as composições não eram tocadas exclusivamente por seus próprios criadores, sendo compartilhadas entre as crianças. Como meio de registrar esse material de maneira mais simples do que pela notação convencional, Coleman se vale de um sistema de notação numérica.

O sistema de notação em questão tinha por intuito possibilitar o acesso à escrita e à leitura de melodias de maneira simplificada. Ele é apresentado neste livro, a primeira exposição do trabalho de Coleman e, também, em outros escritos. É interessante observar que, além de possibilitar o registro de melodias pelas próprias crianças, o uso do sistema serviria, da mesma maneira, aos pais e às mães sem conhecimentos de teoria musical.

De maneira sintética, o sistema consiste em representar as alturas de acordo com a escala, numerando-as de 1 a 8 . As mudanças de oitava, quando ocorrem, são indicadas com traços acima ou abaixo dos números. Visto que servem à notação de melodias simples, geralmente cantadas, os traços colocados acima ou abaixo dos números possibilitam apenas a representação de três oitavas consecutivas (Fig. 5).

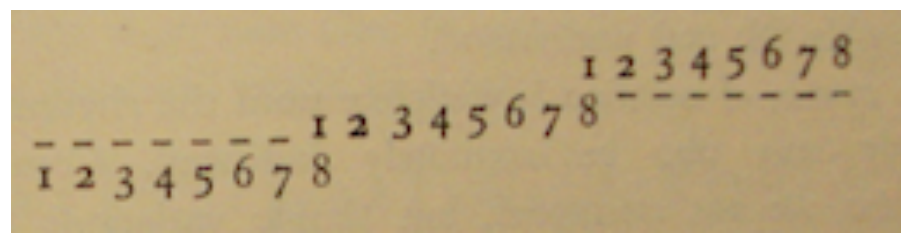

Figura 5 - Esquema de diferenciação de oitavas em sistema numérico de representação de alturas (COLEMAN, 1939, p. 167) 
No que concerne à representação das durações, ainda por ser destinado a melodias simples, o sistema também se vale de princípios básicos. A simples indicação de um número supõe que a altura que ele representa dura uma pulsação. Dois números envoltos em um círculo representam a primeira subdivisão, um traço à direita indica que aquela nota é acrescida de mais uma pulsação e o ponto de aumento é usado de maneira quase similar à notação convencional. $\mathrm{O}$ ponto prolonga a nota que está à sua esquerda e é inserido em um círculo juntamente à nota seguinte para indicar a totalidade de uma pulsação. Contudo, o ponto de aumento não deveria ser usado com crianças pequenas, por ser considerado demasiado complicado para essas (COLEMAN, 1939), assim como a indicação de acidentes. A seguir, o exemplo de uma melodia intitulada América (Fig. 6) onde se pode observar as convenções de representação acima descritas.

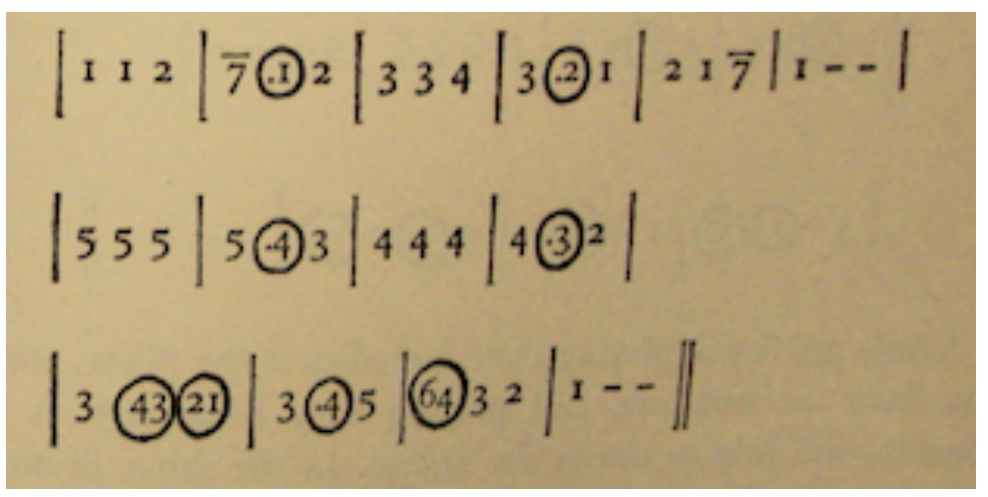

Figura 6 - Melodia América anotada em sistema numérico (COLEMAN, 1939, p. 169)

O sistema numérico utilizado por Coleman conta com estratégias rudimentares para a notação de melodias. Sua limitação condiz, de fato, com o repertório que visa registrar. Ao longo do desenvolvimento das crianças elas seriam capazes de executar peças mais complexas e o sistema de notação também ganharia em complexidade, chegando à partitura convencional.

Cientes de que sistemas similares são encontrados em outros contextos educacionais $^{48}$, o que destacamos aqui não é a engenhosidade do sistema em si. O que nos interessa sobremaneira é o deslocamento operado no papel da notação musical no contexto pedagógico. Na Creative Music, a notação aparece como o que de fato é:

\footnotetext{
${ }^{48} \mathrm{Na}$ França, por exemplo, as discussões sobre a adequação de um método de notação numérico ou convencional datando do mesmo período acontecem sobretudo na revista La Musique à l'École, estão relacionadas também a leitura relativa e são protagonizadas principalmente por Maurice Chevais e Andre Gédalge (VANÇON, 2004).
} 
ferramenta para a prática musical. Sua primazia nos processos de ensino e aprendizagem é reavaliada em prol do fomento à expressão musical das crianças, assumindo forma condizente com os demais traços da abordagem já expostos aqui e da Progressive Education de uma maneira mais ampla. A autonomia das crianças é fomentada neste contexto na medida em que, além de inventarem suas melodias, lhes é oferecida uma ferramenta para que elas próprias possam registrá-las.

\section{A Creative Music como a educação musical progressista}

Creative Music for Children é a primeira grande publicação de Coleman e apresenta as linhas fundamentais de sua proposta de educação musical. Mesmo que seja referente aos trabalhos realizados em estúdio privado, essa publicação é concomitante ao início de sua carreira na Lincoln School, escola laboratório de orientação progressista. Coleman já estava, quando do lançamento do livro, envolta no cenário de renovação escolar objeto de nossa investigação.

Como anteriormente exposto, o livro conta com apresentação assinada por G. Stanley Hall. Trata-se de um texto curto e elogioso, cujo conteúdo antecipa um ponto essencial da proposta de Coleman, presente também nas produções de muitos outros autores e educadores engajados nos movimentos pedagógicos progressistas e escolanovistas do período estudado, a saber, a Teoria da Recapitulação. Hall (in COLEMAN, 1922) apresenta a Creative Music como a melhor realização dessa ideia.

Segundo Alix (2017), por mais que os progressistas tenham aderido massivamente ao "princípio da recapitulação" (ALIX, 2017, p. 107, grifo no original), as conclusões pedagógicas daí derivadas são plurais e mesmo divergentes. Sobre a proposta de educação de G. Stanley Hall, Alix afirma que

Essa pedagogia tem por princípio organizador, ou arquitetônico, a teoria da recapitulação: a ideia segundo a qual a criança, no curso de seu desenvolvimento, passa por uma série de estágios que foram percorridos pela humanidade ao longo de sua história. Nessa perspectiva, a educação ou o ensino escolar deve respeitar estritamente os estágios de desenvolvimento da criança tal como a psicologia genética permite discernir (ALIX, 2017, p. 108, grifo no original) 
Alix (2017) defende que este princípio orientava fortemente o pensamento pedagógico à época e se mostrava de maneiras diferentes nas prescrições sobre a organização dos conteúdos escolares e o papel legado ao educador, entre outros aspectos. Stanley Hall era apenas um nome dentre os vários compreendidos neste cenário, em que o autor aponta também John Dewey. Como observado por Southcott (2009), estes dois autores estavam entre as referências fundamentais do trabalho de Satis Coleman, assim, seria impossível pensar que a educadora e seu projeto estavam alheios à tal configuração teórica. Entretanto, isso se passa de maneira particular no caso de Coleman. A autora, como podemos observar na citação abaixo, não se compromete com este fundamento:

Este trabalho não intenta fundamentar ou discutir a popular Teoria da Recapitulação. A evolução natural da música, entretanto, nos dá uma linha de progressão desde formas simples e adiante, o que é especialmente adequado ao crescimento das capacidades da criança. Este pano de fundo histórico tem sido o campo de onde seleciono o material de acordo com as reações naturais da criança independentemente da sucessão de experiências da raça, e sem entrar nos pontos disputados entre historiadores da música (COLEMAN, 1922, p. 143)

Coleman esquiva-se de tratar diretamente de tal Teoria, no entanto, sua obra é constantemente perpassada pela comparação entre crianças e o "homem primitivo", sendo que este termo refere-se a modos de vida diferentes daquele do grupo social no qual estava inserida. Sempre que mobiliza tal comparação, a autora revela uma concepção da qual não podemos nos eximir de problematizar, visto que complexa e carregada de contradições.

A comparação de crianças com o que autora nomeia "homem primitivo" justifica vários aspectos de sua proposta educativa. Um traço fundamental que observamos em tais comparações é o caráter pré-industrial do "homem primitivo". A construção tanto de instrumentos quanto de músicas é necessária em culturas nas quais ambos não estão disponíveis em um mercado, como o que se desenvolvia nas primeiras décadas do século passado no contexto urbano estadunidense. Essa concepção acaba por dar espaço de ação para as crianças, convidadas a não serem meras consumidoras e a produzirem seus próprios instrumentos e suas próprias músicas. 
A ideia de uma musicalidade espontânea tanto nas crianças quanto em povos de outras culturas também serve como denúncia de uma artificialidade do ensino de música à época. Para Coleman, a ideia de que o estudo de composição só seria acessível a alunos em nível avançado e bem instruídos em conhecimentos de harmonia é uma inversão dos "procedimentos naturais em música" (COLEMAN, 1922, p. 177). Assim, ao mesmo tempo em que se apoia em uma concepção questionável de "musicalidade natural", Coleman possibilita o exercício criativo das crianças ao não submeter a prática composicional a pré-requisitos de grande complexidade.

De maneira a tornar mais evidente o que a autora toma por "homem primitivo", mencionamos dois exemplos dados por Coleman no livro em questão. Ela evoca aborígenes australianos - Bushmen - os quais, de acordo com a autora, têm práticas musicais que duram horas e são desprovidas de funcionalidade (COLEMAN, 1922). Em outro momento, Coleman exalta a musicalidade de afrodescendentes originários do sul dos Estados Unidos, afirmando que esta seria resultante não apenas do histórico de sofrimento desse grupo, mas também seria devida a sua natural predisposição melódica e harmônica.

Essa referência constante a povos tomados como "primitivos" está em conformidade com um paradigma evolucionista. Segudo Alix (2017), a teoria evolucionista de Herbert Spencer estava em voga nos Estados Unidos desde a segunda metade do século XIX e servia de fundamento para a Progressive Education. Essa fundamentação tem variadas consequências, como uma certa "biologização" da aprendizagem, sendo a didática relegada a um patamar de menor importância enquanto a interação do indivíduo com o meio aparece como fundamental para seu desenvolvimento; além de explicitar uma visão etnocêntrica, na medida em que a criança ocidental é comparada a um adulto que teria um desenvolvimento cultural de nível inferior. A atribuição de uma suposta predisposição natural melódica e harmônica aos afrodescendentes sugerida por Coleman está inserida nesse paradigma, o qual nos aparece, na leitura contemporânea, como fortemente inadequado. A crítica de Levi Strauss (1952, p. 5) ao evolucionismo nos alerta para o "pecado original" antropológico, o qual consistiria na confusão entre uma ideia de raça baseada em uma acepção biológica e as produções sociológicas e psicológicas das civilizações humanas. Segundo o autor (1995), tal erro intelectual, mesmo que honestamente não intencional, levava à justificação de situações de discriminação e de exploração. 
Apesar da denominação que hoje compreendemos como inadequada, a comparação entre crianças e povos "primitivos" tem como consequência o reconhecimento, mesmo que com um pano de fundo contraditório, de músicas nãoocidentais dentro do contexto educativo. Ainda que impossível de equiparar com as discussões posteriores a respeito do assunto, uma pequena abertura já estava em vias de acontecer através do uso de determinados instrumentos e repertórios, como avalia Volk:

Nas definições atuais, Satis Coleman não era uma educadora de world music. Seus objetivos com a construção de instrumentos eram baseados em caminhos para promover a criatividade musical de seus alunos. [...] Coleman contribuiu, no entanto, para o nosso conhecimento de maneiras pelas quais o multiculturalismo musical pode ser introduzido em sala de aula. Neste sentido, sua metodologia da creative music continha precursores da educação para a world music (VOLK, 1996, p. 33)

É ainda interessante observar que, na tentativa de se esquivar de tratar o desenvolvimento humano de maneira teleológica, Coleman acaba por fazê-lo no âmbito da música. Isso se explicita no subtítulo do livro: A plan of training based on the natural evolution of music. Segundo Southcott (2009), em artigo que visa reconstruir o quadro de referências identificadas na obra de Coleman, essa organização de diferentes materiais e formas de expressão musicais em uma sequência de desenvolvimento se deve às ressonâncias de um debate que foi muito difundido na segunda metade do século XIX. Na esteira dos estudos evolucionistas, teorias sobre a origem e a evolução da música foram elaboradas e seus ecos são perceptíveis na educação musical do século XX, sobretudo nas primeiras décadas. A sequência de instrumentos de percussão - sopros - cordas ou, em outros termos, o itinerário ritmo - melodia - harmonia, são modos de organizar aspectos da música que diriam respeito à sua evolução nas hipóteses do século XIX e, mais tarde, vêm a assumir caráter didático. Ainda segundo a autora (SOUTHCOTT, 2009), mesmo que o quadro científico tenha sido superado - em 1922 já se questionava a validade da ligação entre filogênese e ontogênese -, a educação musical continuou a basear-se em fundamentos daí decorrentes. Em suas palavras:

Devido a esse trabalho [pesquisa de Walter Garstang em 1922, onde se diz que não há relação entre filogênese e ontogênese], a Teoria da Recapitulação não se manteve. Apesar disso, alguns pressupostos 
continuaram e ainda continuam, embora de uma forma menos ingênua. Mesmo que a refutação fosse amplamente conhecida, a sequência percussão - sopro - cordas arraigou-se. Essa ideia parece relacionar-se a uma necessidade de ordem e alcançou quase certeza mítica. Materiais modernos de educação musical frequentemente começam com o ritmo, progridem para a melodia e, por fim, adicionam a harmonia (SOUTHCOTT, 2009, p. 30)

A apresentação do primeiro livro de Coleman assinada por Stanley Hall, além de situar a Creative Music em um ambiente teórico fortemente marcado pelas ideias evolucionistas e pela Teoria da Recapitulação, a insere, de maneira mais geral, no quadro pedagógico da educação progressista. O livro visa a difundir a proposta da educadora que havia assumido a área musical na Lincoln School, instituição central para o movimento em âmbito nacional e internacional. Tratava-se de tarefa maior do que apresentar os experimentos feitos em seu estúdio particular. O que ganhava publicidade eram os fundamentos que começavam a orientar o ensino de música no cerne da Progressive Education. As particularidades resultantes da realidade institucional são o tema sobre o qual nos debruçamos a seguir.

\section{Creative Music na Lincoln School}

Já no início da década de 1920, a área de Música da Lincoln School era apresentada como constituída por duas seções, Canto e Creative Music. Na descrição das atividades de Canto, os conhecimentos práticos e teóricos ligados estritamente à música vocal são relacionados a objetivos como despertar e estimular o interesse e o “amor pela música” (COLUMBIA UNIVERSITY, 1922, p. 59). Destacamos que a composição também estava compreendida nesta seção, o que é evidenciado no trecho seguinte: "Incentivo e oportunidade para compor são dados às crianças que têm versos escritos ou precisam de música incidental para suas peças de teatro" (COLUMBIA UNIVERSITY, 1922, p. 59).

Contudo, é na seção da Creative Music que à música parece ser atribuída uma abordagem inovadora, visto que, além de todas as características já apresentadas no primeiro livro de Coleman, agora uma de suas marcas é a integração aos demais saberes escolares. 
sequência de experiências musicais nas quais experimentação prática, trabalho manual construtivo e expressão artística estão coordenados. A correlação dos fatores intelectual, manual e estético contribui para o desenvolvimento musical do aluno (COLUMBIA UNIVERSITY, 1922, p. 61)

A atividade musical segundo essa abordagem se mostrava inovadora por fazer convergir esforços intelectuais e manuais em uma perspectiva estética, além de fazer da disciplina uma parte coerente com o quadro escolar global. Na sequência de tal trecho, são apresentadas as áreas às quais as atividades de Creative Music vinham sendo relacionadas, como estudos da língua inglesa, da natureza, de outros povos, de mitologia, etc. Como exemplo de integração ao estudo da língua, e também como mostra de conteúdo específico, apresentam-se programas do trabalho desenvolvido com crianças do quarto, quinto e sexto ano (tab. 5, 6 e 7). É interessante notar que tais programas são bastante similares àqueles constantes no primeiro livro de Coleman (1922), apresentado anteriormente. Destacamos a ênfase dada nos programas às atividades de construção de instrumentos e de composições das próprias crianças.

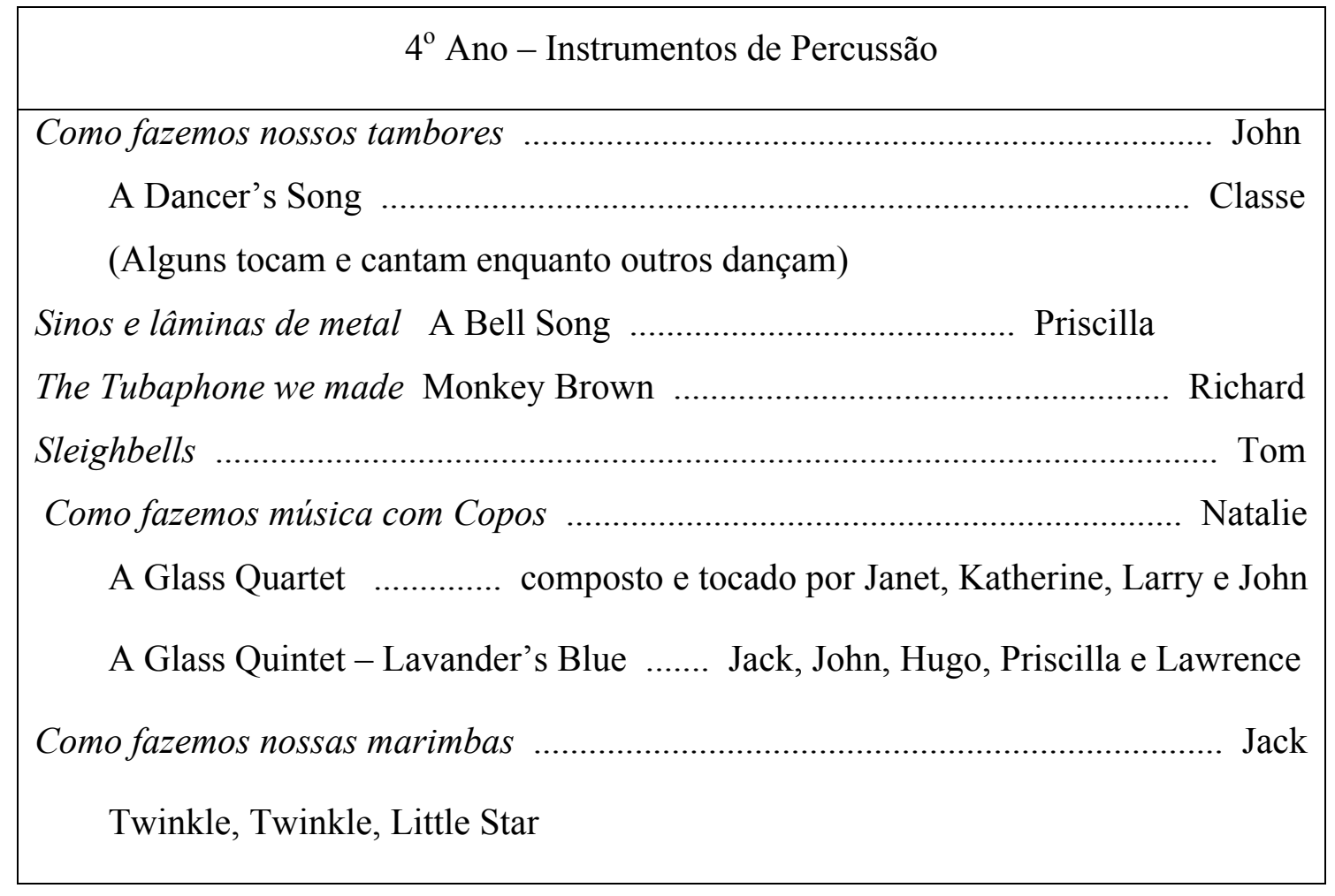


Merrily We Skip Along

The Minor Mode

Duas composições originais em modo menor de Mac e Richard

Wooden Shoe Dance

Classe

Old Mother Hubbard - composta pela classe Classe

Tabela 5 - Programa de trabalho realizado com crianças de $4^{\circ}$ ano nas aulas de Creative Music da Lincoln School (COLUMBIA UNIVERSITY, 1922, p. 61 - 62)

\section{$5^{\circ}$ Ano - Instrumentos de Sopro}

Como fazemos nossas Flautas de Pã Page

Song of Syrinx

A Beethoven Hymn Classe

Instrumentos de Sopro Originais

Tubos de papel da Barbara

David's curved metal bar

Garrafas de água da Helen

William's crab claws

Canudo de leite da Susan

Oboé de cabaça (Gourd oboé), explicado e ilustrado por Page

Trompete, explicado e ilustrado por John

Clarinete, explicado e ilustrado por Sophie

Chinese tohe, explicado e ilustrado por Claire

Triton shell trumpet, explicado e ilustrado por William

Flageolet, explicado e ilustrado por Susan

A Market Song

Good Pierrot Classe

Flautas

Flauta de palheta, explicado por Walker

Flauta chinesa, explicado por Pauline

Flauta de seis chaves, explicado por Sarah 
Piccolo, explicado por Maud

Flauta boêmia, explicado por Elizabeth

Ocarina, explicada por Thalia

Composições originais de Susan, Helen e Sophie

Bird Songs

A classe tocará três cantos de pássaros nas ocarinas para o público adivinhar

Moon Song

Classe

Day is Over

Classe

Tabela 6 - Programa de trabalho realizado com crianças de $5^{\circ}$ ano nas aulas de Creative Music da Lincoln School (COLUMBIA UNIVERSITY, 1922, p. 62)

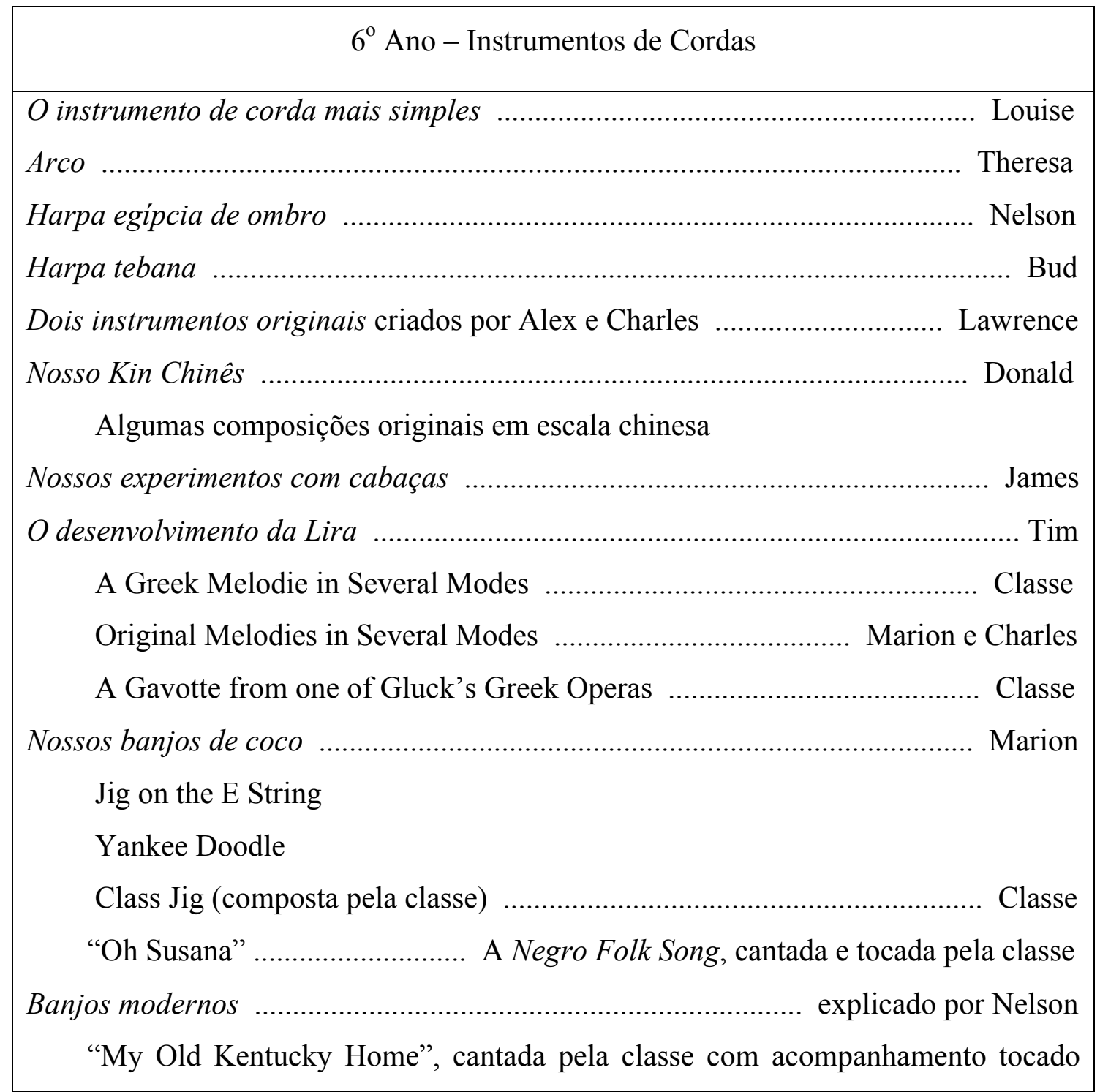


em banjos por Nelson, Tim e Charles

Tabela 7 - Programa de trabalho realizado com crianças de $6^{\circ}$ ano nas aulas de Creative Music da Lincoln School (COLUMBIA UNIVERSITY, 1922, p. 62 - 63)

Esses programas nos permitem afirmar que, ao menos nos três primeiros anos de trabalho institucional, a Creative Music na Lincoln School estava em consonância com as atividades desenvolvidas no contexto do estúdio privado. Contudo, mesmo se tratando de um laboratório progressista, a escola regular apresenta especificidades às quais tal projeto não poderia passar incólume.

Na publicação institucional de 1922 encontramos referência à existência de um coro, de aulas individuais de piano e violino, e da Lincoln School Orchestra. Os três ramos alinham-se a características gerais do ensino progressista, como o estímulo à convivência entre os alunos e a tentativa de integração coerente da prática musical no quadro escolar, mas em sua apresentação não notamos nenhuma menção às práticas criativas ou à valorização da iniciativa das crianças. Esses dois temas, centrais na presente tese, mostram-se efetivamente no livro A children's symphony, lançado por Coleman em 1931, pouco mais de uma década após sua entrada na instituição.

\section{A children's symphony: criação na orquestra escolar}

A publicação de 1931 veio somar-se à então já profícua lista de livros de Satis Coleman. Na década de 1920, além de trabalhar com crianças e na formação de profissionais, a educadora publicou 6 títulos $^{49}$. A children's symphony é o segundo a ser publicado na década de 1930 e apresenta uma característica particular: é uma produção científica, apresentada no âmbito de um processo de doutoramento junto à Columbia University.

O texto é um estudo sobre o trabalho criativo realizado por Coleman com a orquestra escolar, trabalho que resultou na composição de uma sinfonia. Consiste, em

\footnotetext{
${ }^{49}$ A lista de livros publicados até aquele momento, tal qual aparece no título em questão: "Creative Music for Children, 1922. Bells, Their History, Legends, Making and Uses, 1927. Creative Music in the Home, 1928. The Marimba Book, 1926, edição revisada em 1930. First Steps in Playing and Composing, 1927, edição revisada em 1930. Singing Time (com Alice Thorn), 1929. The Drum Book, 1931" (COLEMAN, 1931, p. 219).
} 
suma, na retomada dos primeiros experimentos no estúdio e da insatisfação com o ensino de música, na descrição do projeto de criação de uma sinfonia e de sua execução, e, além das considerações da própria autora diante do experimento, apresenta também avaliações das crianças envolvidas e de suas famílias.

A condição de texto destinado à atribuição de um título acadêmico é tensionada logo nas primeiras páginas, em apresentação assinada por Jesse $\mathrm{H}$. Newlon ${ }^{50}$, então diretor da Lincoln School e professor do Teachers College da Columbia University. Mais do que apresentar a obra, o preâmbulo de Newlon parece ter como objetivo a validação do trabalho de Coleman em meio ao quadro das ciências da educação à época, como podemos observar já no início:

\begin{abstract}
Alguns podem considerar um empreendimento deste tipo como mera inovação, reservando a palavra experimentação para descrever situações em que a medição e o controle precisos são usados para comparar estudos de métodos de ensino e aprendizagem. Mesmo que nenhum estudante de educação cuidadoso tenha ainda questionado o valor de tais experimentos controlados, é ainda assim impossível conceber um empreendimento criativo como o aqui descrito sendo adequado a técnicas de laboratório. Técnicas laboratoriais têm seu lugar na educação, porém, se comparadas com a visão, a imaginação e o discernimento que animam um empreendimento como esse, elas seriam desimportantes (NEWLON, 1931, p. v)
\end{abstract}

Ainda que escape a uma abordagem científica laboratorial, o trabalho de Coleman mostra-se inserido no caldo epistemológico de seu tempo. É interessante observar que, ao mesmo tempo em que sua postura pedagógica é digna de ser objeto de produção de conhecimento, em um momento de sua elaboração textual passa-se pela caracterização das crianças envolvidas e isso se dá segundo testes de mensuração da musicalidade. Ao descrever os grupos com os quais o experimento foi desenvolvido, Coleman vale-se de testes de inteligência, mais especificamente em música, daqueles de Carl Seashore. À primeira vista, seu trabalho rompe com as pretensões de objetividade de experimentação laboratorial, no entanto, apoia-se, em um determinado momento, em uma ideia de fundo positivista. A pretensão de medir

\footnotetext{
${ }^{50}$ Jesse Homer Newlon $(1907$ - 1941) ocupou o cargo de diretor desta escola experimental entre os anos de 1927 e 1934. Desempenhou atividades no Teachers College desde 1927 até sua morte, em 1941. https://www.tc.columbia.edu/arts-and-humanities/philosophy/program-history/ Acesso em 04 jan. $20 \overline{19 .}$
} 
objetivamente a musicalidade das crianças realiza-se, na verdade, como mera medição de sua acuidade auditiva, o que destitui da atividade musical toda a sua carga cultural, histórica e subjetiva. Para Fonterrada (2008), os testes de Seashore são insuficientes tanto em relação ao sujeito que é examinado, visto que prometem medir seu talento, tarefa impossível levando em conta a implicação de um grande leque de habilidades e capacidades mentais e expressivas; quanto em relação à própria música, visto que segundo a metodologia da pretensa medição, as obras e práticas musicais seriam reduzidas a meras somas de parâmetros sonoros, objetos assim desprovidos da complexidade própria à atividade artística.

A pesquisa de Coleman expressa a ambivalência do quadro científico, pois, ao mesmo tempo em que as crianças são objetos passíveis de caracterização a partir de mensurações objetivas, também lhes é atribuído espaço de ação no processo de ensino e aprendizagem e suas opiniões sobre este processo são levadas em consideração na etapa de reflexão sobre o mesmo.

A importância atribuída à participação das crianças evidencia-se desde o subtítulo do livro, a saber: With the themes composed entirely by the children, and played by them on instruments of their own making and other simple instruments. Também no relato do trabalho de composição e execução da sinfonia fica clara a postura de valorização da iniciativa das crianças e da importância de sua atividade criativa. Quando escreve um resumo final do livro, mais uma vez Coleman afirma seu foco nas crianças ao apontar as quatro principais características da sinfonia:

1. Ela foi feita inteiramente de temas das crianças

2. Todas as melodias (não meramente as partes rítmicas) foram tocadas pelas crianças, sobretudo em instrumentos muito simples 3. Muitos dos instrumentos foram feitos pelas crianças 4. Todas as crianças de todas as séries da escola elementar tocaram na orquestra, não apenas crianças selecionadas (COLEMAN, 1931, p. 121)

Destacamos que, assim como no livro em que tratava de seus experimentos em estúdio, Coleman mais uma vez apresenta sua proposta como alternativa a um estado da educação musical que considera inadequado. No primeiro livro, criticava o ensino rigoroso de instrumentos específicos como piano e violino para crianças muito pequenas e, então, expunha como alternativa a Creative Music baseada nos princípios dos quais tratamos anteriormente. Em A children's symphony, em que trata da 
educação musical através da prática orquestral escolar, também parte da crítica ao quadro estabelecido à época e que avaliava como inconveniente. Para isso, Coleman tece críticas tanto às orquestras escolares cujo acesso estava restrito às crianças com habilidades específicas já desenvolvidas, quanto a algo que, no Brasil, se popularizou segundo o termo bandinha rítmica.

No que concerne às orquestras escolares, Coleman afirma que essas podem ser uma grande oportunidade para a vida social e a promoção de experiências musicais na escola. No entanto, a seletividade implicada na criação e manutenção das atividades de uma orquestra pode também ter um efeito danoso na convivência entre as crianças. As exigências para fazer parte do grupo se dariam, geralmente, por talento, oportunidades extraescolares, ou ambos. Segundo a educadora (COLEMAN, 1931), o acesso restrito a tais formações poderia ser perverso, fazendo com que tanto escolhidos quanto os que ficam de fora da orquestra passem a acreditar que a prática musical não é um direito de todos. Assim, a orquestra escolar poderia ser um fator de prejuízo ao "desenvolvimento social saudável do grupo" (COLEMAN, 1931, p. 30), algo caro ao quadro escolanovista.

Outra prática de ensino de música em grupo em voga à época é criticada por Coleman por suas limitações. A banda rítmica é problemática, segundo a educadora (1931), em ao menos três aspectos: (a) exige grande destreza pedagógica para que seja, de fato, uma experiência musical, e não caia em uma situação de barulho generalizado. Isso se deve ao fato de enfatizar o ritmo, sobretudo o pulso, deixando de lado outros aspectos da música; (b) a banda rítmica não tem como ser mais que apenas um pequeno momento do desenvolvimento infantil, visto que seu foco em habilidades rítmicas elementares não tem como garantir a manutenção do interesse das crianças em longo prazo; (c) ela não conduz necessariamente a experiências musicais mais ricas, nem em sua própria execução, nem se constituindo como ponte para a prática instrumental posterior.

Além de apontar tais limitações específicas, Coleman denuncia um vácuo na educação musical escolar, quando ela se apoia apenas nas práticas supracitadas.

Pode-se ver que os grupos instrumentais usuais para crianças têm valor em suas próprias esferas, mas deixam um espaço vazio na vida musical escolar como um todo. Nos níveis mais iniciais eles não dão a oportunidade de fazer música, e nos níveis mais avançados as crianças que fazem parte da orquestra são escolhidas de acordo com uma seleção demasiado exigente. Nenhum nível 
provê oportunidades para que todas as crianças façam música realmente (COLEMAN, 1931, p. 31 - 32)

Atenta a tais problemas, Coleman sugere que sua experiência na Lincoln School pode suprir o vácuo entre a banda rítmica, que não pressupõe desdobramentos, e a orquestra escolar, que se forma com crianças já iniciadas no estudo de instrumentos específicos.

Se todos os membros de qualquer classe são colocados para tocarem juntos depois de passado o período breve da bandinha rítmica, deverá haver um tipo de orquestra que fica entre o nível técnico da bandinha rítmica e aquele da orquestra escolar ordinária. Ao contrário da bandinha rítmica, essa orquestra deve dar a oportunidade de tocar melodias e realmente fazer música, ao invés de meramente bater o pulso; e, ao contrário da orquestra de instrumentos profissionais, esta não deve demandar habilidades técnicas em demasia. Nesta orquestra deve haver um espaço para cada criança em seu nível musical próprio (COLEMAN, 1931, p. 35)

A educadora apresenta, então, seu trabalho desenvolvido com crianças da escola laboratório. A orquestra é formada por crianças que tocam os instrumentos mais variados, dando espaço para aqueles que estão em níveis distintos de desenvolvimento. Também os modos de aprender repertório são variados, havendo crianças que aprendem pela escuta, pela leitura de notação numérica e de partitura convencional. E o que nos interessa sobremaneira na presente tese: a prática composicional é parte das atividades orquestrais.

De acordo com as condições, que não eram mais aquelas de um número reduzido de crianças no estúdio particular, o processo de criação da sinfonia foi conjunto. A peça foi resultado da participação de várias crianças - Coleman conta que, de início, recebeu 75 pequenas melodias das crianças interessadas no projeto - e da adequação final de seus esforços criativos pela educadora. Algumas diretrizes iniciais foram dadas, mas nada que limitasse demasiadamente a invenção das crianças. Consistiram em indicações práticas e relacionadas ao que vinha acontecendo nas aulas de música.

O processo começou sentando ao piano com um cesto cheio de pedaços de papel e tocando cada um deles a procura por um tema, ou um pedaço de tema que soasse promissor. As crianças foram informadas anteriormente de que o primeiro movimento seria em 
compasso $4 / 4$ e, para que fosse adequado às marimbas que vinham sendo construídas pelas crianças do sexto ano, seria melhor que os temas fossem na tonalidade de Fá Maior. Nada mais foi determinado.

O primeiro movimento foi construído com dois temas e outras melodias criadas pelas crianças. A composição do segundo movimento começou com a melodia de uma menina e a ideia de um menino de fazer algo representando os homens primitivos. O terceiro movimento foi um minueto e o quarto, um rondó, pois as crianças aprenderam essas formas e quiseram trabalhá-las (COLEMAN, 1931, p. 48)

Além de participarem ativamente em várias etapas do experimento, as crianças também foram convidadas a expressar suas considerações sobre as atividades orquestrais. Todos os participantes foram convidados a escrever uma carta sobre sua experiência na semana seguinte à última apresentação e, após a entrega da carta, responderam a questionários. As perguntas eram, em sua maioria, abertas e abordavam conhecimentos anteriores ao projeto, principalmente aqueles relacionados especificamente à música orquestral e à prática instrumental; impeliam as crianças a darem opiniões sobre sua experiência pessoal, se o processo havia sido cansativo, alegre, indiferente, etc., e se pretendiam participar mais vezes; induziam a autoavaliação, visto que levavam as crianças a refletirem sobre como a participação no projeto havia interferido em habilidades como concentração, capacidade de trabalhar em grupo, compreensão de uma sinfonia, etc. Visto que o livro trata do terceiro experimento, por isso o título Lincoln School Symphony n.3, crianças que participaram nos anos anteriores também responderam a pesquisa com questionário específico.

Os pais e as mães das crianças foram igualmente convidados a responder a questionários. As perguntas direcionadas aos adultos também eram abertas e abordavam sobretudo a motivação das crianças em relação à sinfonia e à música de uma maneira geral. Através de tal questionário, a educadora buscava compreender tanto as reações das crianças de uma maneira indireta, como quando perguntou se as crianças reclamavam para a família a respeito da disciplina exigida nos ensaios ou do fato de não serem autorizadas a levar o instrumento para casa, quanto à opinião das famílias, como quando perguntou se os adultos avaliam aquela experiência como válida para seus filhos e para a instituição escolar. 
Dentre os comentários da autora em relação aos dados coletados, destacamos o que está em foco na presente tese, a criação musical. Quando comenta as respostas das crianças, há apenas uma menção ao tema, uma criança que diz que a experiência de participar do projeto deu-lhe oportunidade para compor. No entanto, entre os comentários sobre as reações das famílias, tanto nos questionários quanto em conversas informais entre a autora e os pais e mães, o assunto é mais frequente. São vários os exemplos de comentários sobre o impulso criativo fomentado pela experiência, nos quais os adultos relatam que as crianças passaram a improvisar e compor melodias em casa, influenciadas pelo projeto desenvolvido na escola, em situações de aula ou não, como no exemplo seguinte:

Mrs. B, em sete de fevereiro, relatou uma conversa com sua filha de dez anos de idade. "Eu disse a Dora, 'deixe-me escutar você fazendo uma peça'. Dora disse, 'Tudo bem, eu vou fazer uma sinfonia'; eu respondi 'Você quer dizer uma sonata'. 'A forma é a mesma. Vai ter quatro movimentos'. 'Você sabe como fazer uma sinfonia?' 'Sim, é claro que sei'. Então ela tocou quatro movimentos. Eu não sei quão corretos estavam, mas certamente foi muito bonito" (COLEMAN, 1931, p. 84)

A reação das crianças e de suas famílias aparece, de maneira geral, como muito positiva, assim como a avaliação favorável que marca a apresentação assinada por Jesse H. Newlon. Para este educador, o trabalho de Coleman é apreciável por sua capacidade de envolver crianças de diferentes idades, em atividades variadas e criativas e, o que é de extrema importância, insere a prática musical, de fato, no âmbito escolar.

Mrs. Coleman demonstrou que crianças com habilidades musicais amplas e variadas podem se engajar na mais significante atividade criativa e musical na escola básica. Esse experimento não foi uma mera façanha espetacular. Isso foi uma fase de um rico programa experimental envolvendo todos os aspectos da música na escola básica. Desde a construção dos instrumentos, até tocar e compor uma sinfonia, o projeto foi articulado com outras atividades e estudos da escola em muitos pontos (NEWLON, 1931, p. vi)

Atentamos, porém, para o fato de que o sucesso de tal experimento está em consonância com o ambiente de uma escola laboratório, uma das mais importantes no cenário internacional de renovação escolar naquele momento. Em resenha muito favorável datada do ano seguinte à publicação, Pierce (1932) apresenta o livro de 
maneira elogiosa, mas não deixa de apontar para a especificidade das circunstâncias. Pierce (1932) afirma que, apesar do grande valor do trabalho, sua realização seria certamente impossível em muitas escolas. Ela elenca como fatores cruciais para o sucesso do experimento os seguintes: a flexibilidade do programa escolar, a compreensão e o apoio da administração e, sobretudo, um alto nível de conhecimento musical e pedagógico da professora.

Todavia, a apreciação positiva do trabalho de Coleman não era unânime. Desde a década anterior, o trabalho da educadora vinha suscitando comentários que não manifestavam acordo com seu caráter experimental. Dedicamo-nos, na sequência, às críticas negativas e às respostas proferidas a favor da Creative Music.

\section{Dissonâncias em torno da Creative Music}

Em um trecho de A children's symphony, Coleman (1931) empenha-se na defesa de seu trabalho por meio de respostas a possíveis questões que seriam levantadas. Essa postura pode ser compreendida observando demais textos da autora do início da década de 1930 e as publicações sobre educação musical na revista Progresive Education ainda na década anterior. A leitura de tais publicações nos leva a um cenário de discussão sobre a abertura recente na área para uma participação mais ativa, especialmente mais criativa e expressiva, por parte das crianças.

$\mathrm{Na}$ estrutura do texto de doutoramento, após a apresentação da caracterização dos grupos, relato do trabalho e considerações sobre os pontos de vista das crianças e de seus pais e mães, há um capítulo intitulado "Implicações", cujo primeiro texto é “Questões que podem ser levantadas" (COLEMAN, 1931, p. 99). Dentre os temas abordados, interessam-nos as questões quinta e sexta, pois diretamente ligadas ao assunto da composição, a saber: " Não seria um desperdício de tempo para as crianças aprenderem suas próprias composições? Ou aquelas de outras crianças?" e "É realmente produtivo para as crianças dedicarem seu tempo a aprenderem uma sinfonia feita com seus próprios temas, ou outra sinfonia não escrita por um grande compositor?" (COLEMAN, 1931, p. 102). Através das respostas às duas questões hipotéticas, Coleman (1931) argumenta em favor da prática criativa com as crianças, reforçando sua postura pedagógica nos debates sobre educação musical. Ambas as questões supracitadas indagam pela validade das composições das crianças em situação de ensino e aprendizagem, mas não apenas. Tanto as questões quanto suas 
respostas problematizam a centralidade de determinados repertórios na escola e uma ideia de educação musical que enfatiza a reprodução.

Em resposta à primeira questão, Coleman (1931) começa por esclarecer que sua abordagem está comprometida com o desenvolvimento da musicalidade, e que esta se compõe de diversos fatores. A composição de peças que podem vir a ser aprendidas colaboraria para que as crianças tomem esta prática como meio de expressão, estabelecendo um envolvimento íntimo com a música, o que a autora considera um dos traços mais importantes na musicalidade. E isso seria um direito concedido às crianças através de uma educação promotora de espaços de criação para além da reprodução de repertório, seja ele constituído pelos "clássicos", pela música folclórica, etc. Após essa consideração, a autora toca mais diretamente o tema do repertório:

O folclore provê a música perfeita para a criança se suplementado por trabalho original, nenhum dos dois deve ser omitido. $\mathrm{O}$ professor deve julgar o quanto de dedicação às suas composições próprias a criança precisa para manter o equilíbrio feliz entre a apreciação do melhor da música do mundo, a intimidade no manuseio de formas musicais e um grande prazer no seu próprio poder criativo (COLEMAN, 1931, p. 102).

À questão seguinte, Coleman (1931) responde que não haverá outro caminho, pois os "grandes compositores" não escreveram sinfonias adequadas à prática instrumental infantil. Quando muito, nas sinfonias chamadas "infantis", apenas uma pequena parte da percussão é acessível às crianças. Comparando com o ensino de instrumento, Coleman (1931) afirma que o repertório é escolhido de acordo com o desenvolvimento do aluno, procurando atender às necessidades específicas em cada momento. $\mathrm{O}$ valor do repertório estaria ligado, então, à sua pertinência em relação ao desenvolvimento das crianças, e assim também deveria ser com a prática da orquestra escolar.

Tocar um sinfonia simples a qual as crianças amam e com a qual se divertem é uma experiência musical benéfica para elas, não importando quem a compôs; e, se elas ajudaram a criar oferecendo temas, o interesse é naturalmente maior e o sentimento de pertencimento é acrescido. As crianças são, assim, trazidas para uma relação mais próxima com a música sinfônica e desenvolvem um sentimento de intimidade e orgulho ao participarem dessa forma elevada (COLEMAN, 1931 p. 102 - 103) 
Discutir sobre a pertinência do uso de peças compostas pelas próprias crianças em ambiente de ensino implica na reavaliação das relações entre criação infantil e reprodução, bem como das delimitações de qual repertório é digno de ser reproduzido. Essas discussões não são restritas à educação musical, mas consistem no desdobramento, em nossa área específica, de uma tensão maior. A revolução copernicana escolanovista postulou que a criança era o novo centro da escola e o fez mobilizando termos como liberdade e expressão, ao mesmo tempo em que se impunha como desafio a revisão dos papeis do adulto e dos saberes constituintes dos currículos. A esse respeito, são exemplares alguns títulos de conferências da New Education Fellowship já na década anterior, a saber: "A expressão criativa da criança”, Calais, 1921; “A atividade espontânea da criança”, Heidelberg, 1925; "Qual sentido atribuir à palavra liberdade em educação?", Locarno, 1927. A associação estadunidense passa a fazer parte da New Education Fellowship apenas em 1932, mas tais discussões não são exclusividade da organização europeia.

No cenário estadunidense e no âmbito específico da música, encontramos críticas ao trabalho de Coleman que colocam em evidência seu caráter inovador. A educadora, ao finalizar $A$ children's symphony, deixa claro que o foco em seu experimento é a criança: "É preciso estar atento para que este tipo de trabalho seja empregado de maneira a promover um ótimo crescimento da criança" (COLEMAN, 1931, p. 122). Para exemplificar o quanto este pensamento causava divergências, tomamos como exemplares as críticas elaboradas por Thomas Whitney Surette (1861 $-1941)^{51}$.

Em 1927, a associação Progressive Education publicou um número de sua revista integralmente dedicado à educação musical ${ }^{52}$. Nesta publicação, consta um artigo de Surette, intitulado A general view of music education for children. No texto o autor expõe propostas para um programa de música na escola, mas para tanto, parte de uma crítica que, apesar de não nomeada, parece direcionada à Creative Music. Uma tensão que perpassa o texto é o suposto prejuízo ao ensino da música quando da assunção da criança como centro do processo educacional.

\footnotetext{
${ }^{51}$ Referências à produção deste educador na revista Progressive Education constam na seção "Autoras e autores" do presente capítulo.

${ }^{52}$ Aqui usamos como fonte a edição especial de 1932, a saber: HARTMAN, Gertrude; SHUMAKER, Ann (org.). Creative expression: the development of children in Art, Music, Literature and Dramatics. New York: The John Day Company, 1932. Trata-se de uma compilação dos números dedicados à cada uma das linguagens artísticas em anos precedentes.
} 
Surette (1932) abre o artigo afirmando que, naquele país, o termo creative expression vinha sendo empregado de maneira demasiadamente restrita. Para explicar tal asserção, enfrenta diretamente aspectos amplamente defendidos por Coleman, como a composição de melodias e a construção de instrumentos.

Por vezes as escolas parecem considerar que o termo [creative expression] significa apenas trabalho original, seja na forma de melodias compostas pelas crianças ou instrumentos construídos por elas. Mesmo que isso seja, em algum sentido, criativo, penso que é um erro grave evidenciá-los como vem sendo feito em algumas escolas. Isso é um erro porque nenhum desses projetos é importante no treinamento da criança em música, e porque ambos tomam muito tempo. Todos os momentos de um programa de música liberal poderiam ser empregados de maneira proveitosa ensinando música de verdade para as crianças e desenvolvendo suas habilidades para isso (SURETTE, 1932, p. 69, grifos nossos)

A respeito da construção de instrumentos, o autor não passa da avaliação de que tal tarefa demanda muito tempo. A prática da composição, por sua vez, é objeto de mais um argumento desfavorável, em que a tensão sobre a validade do exercício criativo musical das crianças é evidenciada. Em um primeiro momento, Surette estabelece uma comparação com as áreas de desenho e poesia. Para o autor (1932), as crianças se servem de suas experiências visuais para desenhar e da linguagem comum para a criação poética, ao passo que, em música, elas estariam desprovidas de material. Mais adiante, esboçando um esquema do desenvolvimento musical, a composição surge novamente como atividade a ser postergada porque dependente de estágios anteriores: "Prática instrumental deveria vir após uma longa experiência em canto; composição (criação de melodias), depois de uma longa experiência da música como uma arte" (SURETTE, 1932, p. 71).

É interessante observar que mais um aspecto da crítica de Surette se mostra no trecho supracitado. $\mathrm{O}$ autor se coloca em defesa do canto como mais oportuno em relação à prática instrumental na escola repetidas vezes no referido artigo. Para ele (1932), o canto seria mais apropriado à expressão, visto que uma prática mais íntima que aquela que se dá pela manipulação de objetos. Ao argumentar a favor do canto, Surette opõe uma pretensa naturalidade deste àquela própria à associação da infância a um estágio percussivo. Em suas palavras: “Afirmações absurdas são feitas pra justificar a iniciação musical pelo instrumento no lugar da voz, tal como a ideia de que a criança não treinada estaria, naturalmente, no estágio percussivo da música; [...] 
É verdade que crianças pequenas têm um senso de ritmo; [...]. Mas elas têm um senso mais desenvolvido de afinação" (SURETTE, 1932, p. 69).

Alguns anos depois, em texto de 1930, Surette deixa clara sua oposição aos fundamentos da Creative Music e o faz de maneira a nomear Satis Coleman, mesmo que não se oponha à educadora de maneira específica. Quando critica a ênfase dada por certas escolas - as quais não identifica - a atividades como a composição e a construção de instrumentos, as toma como limitadas e acrescenta: "Imagino que Mrs. Coleman, que tem um trabalho pioneiro e valioso nesse campo, seria a primeira a lamentar os exageros" (SURETTE, 1930, p. 113).

Surette (1930) se volta, em tal artigo, contra o que denuncia como um destaque exacerbado à self expression na educação musical de crianças à época. É neste momento que o autor se aproxima de um tema que agrega conflitos em meio às discussões sobre movimentos escolanovistas, a saber: a educação como transmissão de cultura ${ }^{53}$. Neste caso específico, fica claro que o incômodo de Surette em relação à self expression deriva do entendimento de que à educação musical cabe o papel de transmitir um legado.

\footnotetext{
${ }^{53}$ As discussões sobre o papel da educação, sobretudo da instituição escolar, como transmissora de cultura são numerosas e não se restringem a esse momento. Segundo Alix (2017), desde a década de 1950 até os dias de hoje diversos intelectuais, historiadores e educadores interpretam os problemas da educação estadunidense como resultantes do pensamento progressista. Essa linha de interpretação tende a atribuir ao movimento a disseminação de princípios anti-intelectuais e da dissolução da formação escolar. Uma crítica célebre é aquela desenvolvida por Arendt (2014) no artigo A crise na educação, parte da obra Entre o passado e o futuro, onde a autora apresenta reflexões de filosofia política e, especialmente, sobre filosofia da história. Arendt identifica seu tempo, meados do século $\mathrm{XX}$, como um momento marcado por uma crise geral que acomete "quase toda esfera da vida e se manifesta diversamente em cada país, envolvendo áreas e assumindo formas diversas" (ARENDT, 2014 p. 221). Para a autora, as problematizações envolvendo os lugares do currículo e da criança no sistema de ensino dos Estados Unidos são expressão de uma grande crise da transmissão de cultura. $\mathrm{O}$ artigo desenvolve uma crítica assaz complexa no âmbito da política e foge ao nosso objetivo discuti-lo de maneira pormenorizada. Destacamos, contudo, alguns pontos que elucidam a problemática trazida à luz pela autora: segundo Arendt (idem), tanto a psicologia quanto o pragmatismo fizeram da pedagogia uma ciência focada no ensino, abrindo mão do que é ensinado. A crise na educação seria um desdobramento da crise da tradição na medida em que desvela a tensão própria à modernidade em se relacionar com o passado. A educação, em um mundo que já não se estrutura mais segundo a autoridade nem se mantém coeso pela tradição, vê-se em crise pois não consegue abandonar tais categorias. $\mathrm{O}$ educador, segundo a autora (idem), encontra-se em dificuldade pois seu ofício exige dele a mediação entre o velho e o novo, não podendo este agente se eximir do respeito ao passado. Diante da profundidade que adquire a questão do papel da educação como transmissora se tomada em sua dimensão histórico-filosófica, apontamos para a grande contribuição de estudos que se dediquem ao estudo do ideário pedagógico em sua complexidade, ultrapassando os discursos de senso comum reproduzidos, por vezes, pelos próprios educadores ligados ao movimento. Nesse sentido, destacamos, por exemplo, as considerações esclarecedoras de Alix (2017) sobre o pensamento de John Dewey referentes ao currículo ou à relação entre escola e democracia.
} 
Certamente, um de nossos maiores deveres em relação às crianças é colocá-las em contato com o que de melhor fizeram no passado, ensiná-las assim o significado do mundo, seus lugares nele, seus deveres em relação a ele, e dá-las self expression dentro desses limites. [...] Há uma grande massa de leis e tradições e um mundo inteiro de beleza que constitui um ambiente necessário e limitador para todos nós, ao qual os jovens devem ser ensinados a se ajustarem (SURETTE, 1930, p. 113, grifos nossos)

O conteúdo específico do que o autor compreende por "leis e tradição" não é definido claramente neste trecho, mas suas considerações sobre repertório nos dão pistas do que seria, segundo ele, mais valioso do que as composições das crianças. Ao apresentar suas prescrições, sempre enfatizando a educação através do canto, Surette (1930) afirma que o país só terá o hábito de cantar se fizer uso de canções que possam ser passadas prazerosamente de geração em geração. O hábito do canto deveria se basear na continuidade do repertório composto de "boas canções", as quais, segundo o autor (SURETTE, 1930, p. 108), são “canções folclóricas e de compositores reconhecidos".

A crítica de Surette parece-nos exemplar do conflito engendrado pela tentativa de reorganizar os eixos da instituição escolar. O apelo a ideias como transmissão e continuidade pode ser compreendido como resposta às reconsiderações sobre o valor de paradigmas até então estabelecidos. Quando Coleman questiona: "Não seria mais significativo no seu [da criança] desenvolvimento ser capaz de criar uma canção encantadora do que saber com precisão os detalhes de tudo o que Chopin compôs?" (COLEMAN, 1922, p. 179), a educadora coloca em evidência que seu trabalho tem como foco a criança, não mais o repertório a ser transmitido. Coleman tampouco nega o valor de tal repertório, contudo, reavalia seu papel e seu uso educativo no desenvolvimento infantil.

A leitura de conflitos entre ideias de educação musical no cenário em questão nos exige prudência à medida que, concordando com Saviani (2008), reconhecemos que os discursos nos quais se funda e através dos quais se difunde o ideário escolanovista resvalam, por vezes, em um apelo contundente próprio a slogans. Neste sentido, a defesa da valorização da transmissão de repertório não apenas se dá pela apresentação de argumentos, mas encontra sua síntese na seguinte frase de efeito com a qual Surette encerra um de seus artigos: "O mundo não começou ontem" (SURETTE, 1930, p. 114). Da mesma maneira, não seria sensato acreditar que a oposição à abertura para as práticas criativas na infância seja o estudo pormenorizado 
de toda a obra de Chopin, como sugere Coleman ao defender sua abordagem. Ambos os educadores tentam convencer seus leitores e, relevando exageros como os supracitados, observamos como núcleo da divergência o espaço de ação atribuído às crianças.

A postura defensiva de Coleman em $A$ children's symphony, quando ela elabora e responde questões que poderiam contestar seu trabalho, pode ser percebida também em outra publicação do mesmo ano, um texto resultante da $11^{\text {a }}$ Conferência Anual da Progressive Education ${ }^{54}$. Neste evento, a educadora preside uma conferência coletiva sobre a Creative Music. Sua presença no programa como organizadora de uma seção onde outros educadores ${ }^{55}$ expõem desdobramentos de seu trabalho comprova que a influência de seus experimentos na Lincoln School é central para a Associação. Porém, sua introdução às falas dos demais educadores indica a existência do campo de dissenso apresentado anteriormente. Nesta apresentação, Coleman dirige sua defesa principalmente àqueles que se opõem às atividades de construção de instrumentos, como se observa a seguir:

O plano de deixar as crianças fazerem instrumentos simples encontrou oposição considerável de alguns músicos que esquecem quão significativas são essas coisas elementares para as crianças, e quão enriquecedoras são essas experiências; que estão mais preocupados com a arte da música como algo isolado que em sua função na vida da criança; mais preocupados com padrões fixos a

${ }^{54}$ Evento realizado entre os dias 26 e 28 de fevereiro de 1931, em Detroit, Michigan. Segundo programa divulgado na revista da Associação (PROGRESSIVE EDUCATION, 1931), a conferência coletiva presidida por Satis Coleman ocorreu na tarde do dia 27 em meio ao conjunto de comunicações que tinha como tema How I do it, consistindo em apresentações de experiências didáticas.

${ }^{55} \mathrm{Na}$ ocasião, as três conferências seguintes foram proferidas: (a) POTTER, Edith. Values in the use of instruments in school projects. A educadora da Avery Coonley School de Downers Grove - Illinois, expõe projetos nos quais a Creative Music é parte de projeto de integração entre diversas disciplinas, como história, teatro, etc. (b) DUSHKIN, David. Some experiments in music in the Glencoe Public Schools. O educador, também de Illinois, expõe o trabalho de construção de instrumentos desenvolvido em sua escola. Enfatiza que o interesse em construir um instrumento está estritamente ligado ao uso que se faz dele em seguida e à possibilidade de se chegar também ao uso do instrumento profissional. Relata que as crianças compõem individualmente e em grupo desde o início das aulas. Naquele momento o educador trabalhava na compilação de textos pra auto instrução das crianças e elaborava iniciativas para a integração das famílias em tais atividades. (c) FELLOWS, Alice. Creative Music and the bad boy. Fellows trata de casos em que, através de atividades de construção de instrumentos e composição musical, problemas de comportamento foram solucionados. A Creative Music aparece, na exposição da supervisora das escolas públicas de Toledo - Ohio (Fig. 7), como espaço que contribui para a resolução de conflitos e para a integração com outras disciplinas. Em um dos exemplos, as crianças construíram um instrumento para a trilha de uma peça de teatro e trabalharam em colaboração com moradores do bairro de origem chinesa. Há ainda registro de uma comunicação cujo texto não foi publicado, de Abbie Phillips da Ballard Memorial School, Kentucky. Além da conferência coletiva, o evento também contou com uma exibição de instrumentos construídos por crianças das escolas apresentadas pelos conferencistas, entre outras. 
serem atingidos que no processo educativo que conduz a criança, desde onde ela está agora, através de experiências que lhe são vitais, até o mais longe que ela pode ir. É muito fácil esquecer a criança quando se exalta uma Arte (COLEMAN, 1931b, p. 334)

Mais uma vez a educadora se apresenta em favor de uma educação musical centrada na criança e em oposição àqueles que tomam como prioridade o treinamento para a reprodução de repertório. Porém, na mesma abertura, Coleman (1931b) adverte que a construção de instrumentos é apenas um dos diversos ramos de trabalho com os estudantes.

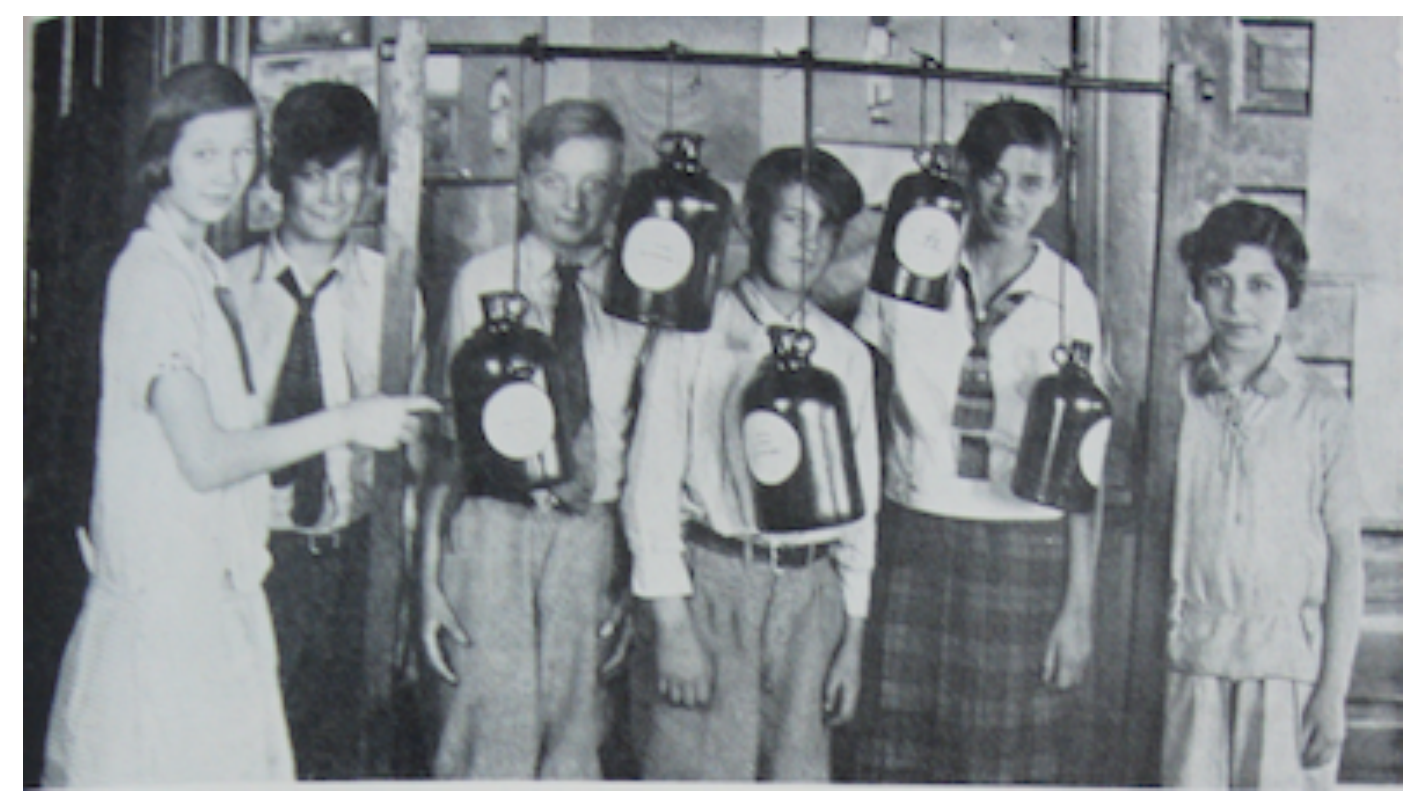

Figura 7 - Ilustração de conferência de Alice Fellows a respeito de experiências em Creative Music nas escolas públicas de Toledo, Ohio (PROGRESSIVE EDUCATION, 1931, p. 331)

A tensão entre críticos e apoiadores da Creative Music em meio às publicações da associação Progressive Education em nossa periodização tem sua última ocorrência evidente em artigo de Coleman publicado na edição de dezembro de 1932/ janeiro de 1933. O artigo, intitulado The progress of the movement for Creative Music, conta com uma breve introdução assinada pela editora, que à época era Ann Schumaker. Na nota de introdução, Schumaker apresenta Coleman de maneira sucinta e anuncia que o artigo, além de um depoimento sobre o desenvolvimento do trabalho, era também uma oportunidade para que a educadora esclarecesse alguns mal-entendidos relacionados a sua proposta em emergência, sobretudo, entre supervisores. 
$\mathrm{O}$ artigo consiste em um resumo da trajetória de trabalho, desde os primeiros experimentos em estúdio privado, até aquele momento, com ênfase na publicação do primeiro livro, em 1922, e sua repercussão. Pelo pioneirismo da proposta e por ser sua primeira obra de divulgação, Creative Music fo Children não teve recepção unânime. Segundo a autora (1932/33), entre os educadores, o livro foi muito bem aceito por alguns e visto com desconfiança por outros; entre pais e mães, a resposta foi massivamente positiva; e, entre supervisores, a proposta foi lida sem interesse. Coleman (1932/33) acredita que a falta de abertura de tal grupo se deve a três fatores: (a) alguns consideram a proposta nonsense; (b) outros acreditam que o trabalho é impraticável na escola, visto que demanda muito tempo e atenção dos educadores e (c) "talvez muitos deles estejam tão fundamentados em procedimentos convencionais que acabem por considerar qualquer interferência como uma heresia" (COLEMAN, 1932/33, p. 28).

Porque amplamente difundida e por não ser construída com a rigidez de um método, a proposta de Coleman se desdobra em diferentes espaços e com diferentes adaptações na década de 1920. Enfatizando que não fez um produto a ser comercializado e controlado, a educadora se exime das más aplicações que a Creative Music pode ter sofrido, como a incompreensão de que a educação musical se faz de diversas maneiras, não apenas pelos aspectos mais valorizados no seu trabalho, mas também através do canto e da apreciação; ou ainda da atenção exacerbada a uma etapa do processo, como a construção de instrumentos, em detrimento do seu uso musical. No entanto, mesmo diante da impossibilidade de responder por tudo o que se fazia em nome da Creative Music, a autora assume que, passada uma década de difusão, seria mais proveitoso naquele momento dedicar-se ao aperfeiçoamento das práticas que à argumentação a seu favor (COLEMAN, 1932/33).

Ainda que reconheça que os desdobramentos de seu trabalho podem ter sido problemáticos, Coleman não aceita passivamente as críticas. Além da nota de introdução do artigo apontar que este é um espaço de esclarecimento e das divergências exemplificadas pela produção de Thomas Surette, já apresentadas aqui, há ainda, neste texto, menção a críticas advindas de outros espaços. Coleman enfrenta tal situação com abertura, contudo, sublinha que há críticos que não conhecem devidamente a proposta. Em suas palavras: 
Eu compreendo que toda inovação deve ser necessariamente criticada, tanto por aqueles que se aprofundam nela, quanto por aqueles que apenas lhe lançam um olhar superficial. É somente pela crítica sincera dos descrentes que os pontos fracos de um sistema podem ser erradicados e os pontos fortes ganham mais vida. Longe de ressentimentos, eu considero bem-vinda a crítica honesta de educadores e musicistas de pensamento sério e que investigaram o trabalho cuidadosamente (COLEMAN, 1932/33, p. 30)

Acrescenta ainda que, já em seu primeiro livro, deixava claro que sua proposta apresentava limites e era apenas um dos ramos da educação musical, o qual poderia contribuir para o programa escolar, complementando e articulando-se com outros ramos, para fundar experiências artísticas com as crianças. Coleman encerra o texto reiterando, ainda com citação de seu primeiro livro, os objetivos de sua proposta.

[...] é esperado que, em muitos casos, a proposta provoque um interesse por boa música; em alguns casos, que sejam descobertas capacidades adormecidas; e, em todos os casos, estimule o poder criativo, cultive a intimidade e o entendimento das ferramentas do fazer musical, e favoreça experiências musicais que vão, através da satisfação, levar os indivíduos a níveis mais ricos de vivência (COLEMAN, 1932/33, p. 31, grifos nossos)

A citação precedente, bem como toda a discussão em torno da Creative Music, sua experimentação na Lincoln School e seus desdobramentos no movimento de renovação escolar, confirmam nossa tese de que a criação musical infantil já era aspecto presente e de grande importância neste cenário. A obra de Satis Coleman é um exemplo de como a promoção dos processos criativos era ponto fundamental para a reflexão sobre e a prática em educação musical quando alinhadas ao pensamento pedagógico mais amplo da Progressive Education Association. A valorização da ação das crianças no ambiente escolar passa, em nossa área, pela consideração de sua atividade composicional. Isso se dá, certamente, de maneira condizente com o pano de fundo epistemológico e cultural do momento histórico aqui delimitado. Para complementar a análise da obra de Coleman, já apresentada anteriormente no que se refere aos primeiros experimentos em estúdio particular e à realidade institucional na escola laboratório, nos dedicamos às suas considerações sobre a relação entre educação musical e família, na seção a seguir. 


\section{Creative music e a família}

A reorganização das relações escolares em voga no cenário estudado diz respeito, em um primeiro momento, aos papéis atribuídos a educadores e estudantes e aos vínculos estabelecidos entre estes. Revisa-se a hierarquia da instituição, admitindo que as crianças não sejam apenas meras receptoras de conteúdos, mas tenham também papel ativo nos processos de ensino e aprendizagem. Isso se dá por razões tanto ligadas ao desenvolvimento das pesquisas em psicologia, que levam à contestação de métodos de ensino baseados em processos restritamente mentais e à valorização de atividades manuais, quanto por mudanças culturais que, ao longo de um processo de mais de quatro séculos, transformam a criança em sujeito de direitos, valorizado em suas especificidades e digno de comprometimento ético por parte dos adultos ${ }^{56}$. Revisa-se, da mesma maneira e também por diversos motivos - sobretudo pela ressignificação social da escola, à qual, guardadas as especificidades socioeconômicas de diferentes países, uma parcela cada vez maior da população tem acesso ${ }^{57}$-, os objetivos da educação escolar.

\footnotetext{
${ }^{56}$ Sobre a transformação das ideias de infância no ocidente nos últimos séculos, sobretudo a partir da escolarização como marco institucional próprio a essa fase da vida, os trabalhos do historiador Phillipe Ariès $(1914$ - 1984) são basilares. Sobre as atribuições éticas em relação à infância na Educação Nova, lemos no trabalho de Jacquet-Francillon (2004, p. 30) traços como "[...] apreciar e celebrar na infância um estado que possui uma dignidade própria, que não se deve prejudicar, rebaixar, nem ignorar em favor de razões alheias [...]". Segundo o autor, é em consonância com essa nova disposição ética que se desenvolvem avanços propriamente políticos, como a superação da aceitação inconteste dos castigos físicos e a concepção de uma organização da comunidade escolar baseada em princípios democráticos. ${ }^{57}$ A população escolar aumenta consideravelmente em diversos lugares nas últimas décadas do século XIX e nas primeiras décadas do século XX. Segundo Alix (2017), baseando-se em dados do Centro Nacional de Estatísticas Educacionais dos Estados Unidos, o número de inscritos na high school em estabelecimentos públicos de Chicago passa de 203.000 no ano de 1889 - 1890 para $2.200 .000 \mathrm{em}$ 1919 - 1920. Segundo o autor, esse intenso crescimento de matrículas também se dá nos outros níveis de educação no país. A situação de multiplicação rápida da população escolar faz com que, de acordo com Alix (2017), a Progressive Era seja também uma Era das Reformas, visto que o poder público se mobiliza para dar conta das contundentes transformações sociais envolvendo a escola. Oelkers (1995) afirma que, juntamente com a desenvolvimento de novas ciências da educação, o período da virada do século tem como característica o fato de que as reformas educacionais deixam de ser assunto apenas das autoridades, mas passam ao domínio da opinião pública. No Brasil, a segunda metade do século XIX é palco de numerosas propostas de reformas não levadas a cabo pela falta de ajuste entre ideias políticas e ideias pedagógicas e pela dificuldade em tornar mais abrangentes as iniciativas regionais. Segundo Saviani (2013), é apenas no início do século XX, sobretudo na década de 1920, que, no debate de ideias liberais, a universalização da escolarização é considerada um instrumento de participação política, com vistas a transformar "indivíduos ignorantes em cidadãos esclarecidos" (SAVIANI, 2013, p. 177). Tratando do "Manifesto dos Pioneiros da Educação Nova", datado de 1932, o autor (SAVIANI, 2013) considera que, mais que um documento em defesa de uma ideia pedagógica específica, o Manifesto consiste em uma defesa da escola pública, propondo um sistema amplo que abrange desde a educação infantil até a formação de uma elite intelectual universitária. Na França, datam do fim do século XIX os esforços de universalização da escolarização com as "leis escolares de Jules Ferry". No ano de 1882 o ensino primário, implicando meninos e meninas de seis a treze anos de
} 
Levando a reavaliação das relações entre educadores e estudantes mais adiante, compreende-se que, para além do quadro institucional, o que se configura é uma reavaliação das relações entre adultos e crianças. Jenkins (2000), em estudo sobre a New Education Fellowship - associação europeia em seu início e da qual a Progressive Education se torna parte em 1932 - aponta para o caráter duplo do cenário de crítica negativa ao autoritarismo e defesa positiva da liberdade no ensino. Se em tal momento as relações entre adultos e crianças são redimensionadas, a relação parental não poderia ser negligenciada como parte da educação. Em seu trabalho, a autora (JENKINS, 2000) observa que, à centralidade da criança nos discursos da NEF na década de 1920, é incorporada a importância da família na década de $1930^{58}$. Isso se torna evidente com a mudança de nome da revista inglesa que, de The New Era, passa a The New Era in Home and School nos anos 30, e pelo direcionamento dos textos à educação de pais e mães, buscando sugerir uma postura adequada deles em relação aos seus filhos e filhas. Soma-se a isso a intenção escolanovista de compreender a criança em seu contexto anterior à instituição de ensino, o que significa levar em conta seu ambiente domiciliar e suas relações familiares.

$\mathrm{Na}$ esteira do movimento de integração da família no discurso da educação escolar, podemos observar no trabalho de Coleman seus desdobramentos específicos no âmbito da música. A educadora publicou ao menos dois livros dedicados particularmente aos pais e às mães, a saber: Creative Music in the Home, de 1924, e Your child's music, de 1939. Através dessas obras, Coleman advoga pela importância da educação musical, buscando convencer os familiares que não são músicos, e também concedendo um papel a eles no desenvolvimento musical das crianças.

O papel concedido à família não é apenas de promotora ou auxiliar do aprendizado das crianças, mas também incentiva-se a prática musical coletiva

idade, torna-se obrigatório. No entanto, a referida lei admite o ensino domiciliar. O que estava de fato em questão era a laicização deste nível de ensino, transferindo-o do domínio da Igreja para o Estado. Assim, a educação firmava-se como assunto público e a religião ficava circunscrita ao âmbito privado. Sobre as leis escolares de Jules Ferry, conferir: http://www.senat.fr/evenement/archives/D42/index.html Acesso em 17 de jan. de 2019.

${ }^{58}$ Também em uma avaliação das mudanças entre as décadas de 1920 e 1930, Haenggeli-Jenni e Hofstetter (2011), ao analisarem a revista Pour l'Ère Nouvelle, publicação francófona da NEF, apontam uma tendência de abandono do caráter idealista e centrado no indivíduo no correr destes anos. Segundo as autoras (idem), toma lugar uma postura mais voltada às práticas pedagógicas, que tentava conectar estas à manutenção da democracia e encarar os indivíduos e as estruturas educativas em suas realidades sócio-históricas. É de grande importância observar que os movimentos de renovação escolar apresentam, de uma maneira geral, inclinação internacionalista, e o período de mudança da década de 1920 para a de 1930 é palco de crescimento do nacionalismo em diversos países. 
doméstica. Neste sentido, é exemplar a ilustração (Fig. 8) em que três pessoas fazem música de câmara, das quais duas são claramente representações de crianças, seguida da frase: "A mais duradoura intimidade com a música estabelece-se em casa" (COLEMAN, 1939, n.p). Tal mensagem encontra-se logo na abertura do livro Your child's music, cujo conteúdo nos serve aqui de material para analisar esta faceta da produção da autora.

O principal objetivo do livro, segundo Coleman (1939), é esclarecer fatores que influenciam as experiências musicais das crianças e sugerir meios pelos quais os pais e as mães podem se servir desses fatores para incentivar seus filhos e filhas. $\mathrm{O}$ que nos interessa especialmente, pois revela a consonância das ideias da educadora com o ideário escolanovista de uma maneira geral, é o fato de que o incentivo não é basicamente à prática do canto ou de um instrumento. $\mathrm{O}$ que a autora busca, e aqui em parceria com familiares, é a promoção do que ela intitula seeking attitude.

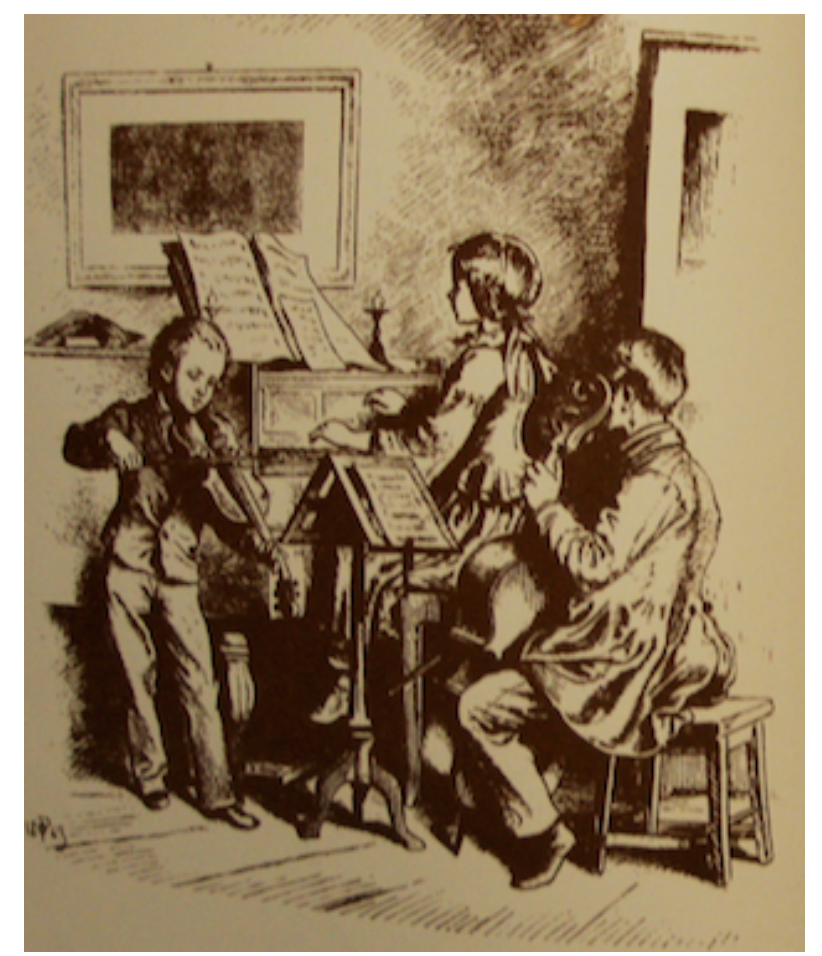

Figura 8 - Ilustração de abertura do livro Your child's music. No livro, sob a imagem, consta a mensagem "A mais duradoura intimidade com a música estabelece-se em casa" (COLEMAN, 1939, n.p)

A seeking attitude é, nas palavras de Coleman (1939, p. 16), em diversas áreas, "[...] uma busca por experiência: a ação de uma força dinâmica que leva o indivíduo às próximas descobertas e a um maior uso do que já foi descoberto; que demanda mais habilidades da área e um maior uso das habilidades já desenvolvidas”. 
Seu contrário seria a avoiding attitude, caracterizada pelo desejo de escapar às experiências. Nestas formulações, a referência a John Dewey é explícita. Coleman (1939) refere-se ao filósofo para afirmar que o aprendizado se dá exclusivamente pela experiência, e esta depende de interesse sincero. De modo a exemplificar tal ideia, sobretudo a importância do interesse daquele que aprende, a autora escreve que tanto pais quanto professores podem forçar uma criança a sentar-se ao piano e praticar, no entanto, isso não significa que essa criança de fato aprenda música. O aprendizado é, assim, estritamente vinculado ao engajamento pessoal.

Com vistas a orientar os responsáveis pelas crianças, Coleman trata de uma série de fatores que influenciam o interesse e contribuem para a seeking attitude. Dentre eles, dedicamo-nos àquele ligado à presente tese: a promoção de experiências criativas. Em seguida, apresentamos também algumas considerações sobre um fator intitulado como A música que a criança escuta, visto que abarca um assunto de interesse histórico: a propagação do hábito de escuta de música gravada e sua relação com a educação musical.

Sobre a criação musical, mais uma vez encontramos a defesa de que essa prática não é mais exclusividade daqueles que têm amplo conhecimento, mas uma atividade a ser incentivada desde a infância e por toda a vida. Os motivos para isso são o prazer daí decorrente e a capacidade resultante de compreensão e apreciação de músicas de uma maneira geral. A atividade de criação deveria se basear na organização de alturas e ritmos guiada pela experimentação e o pelo julgamento de quem compõe.

Coleman (1939) trata de maneira particular a expressão musical espontânea de crianças muito pequenas, que especifica como por volta de três anos de idade. Nesse caso, a autora defende que seria mais apropriado chamar a criação de "melodias acidentais" (COLEMAN, 1939, p. 43), visto que as crianças cantam e não necessariamente estão atentas ao ato nem comprometidas com o resultado. A educadora aconselha as mães no cultivo do hábito de cantar melodias espontâneas, argumentando que assim se estimula a improvisação e a expressão musical livre.

Tanto para crianças muito pequenas quanto para as maiores, Coleman (1939) dá sugestões de como a criação musical pode ser estimulada a partir de situações corriqueiras no âmbito doméstico. Quando trata dos improvisos de canções, sugere que um passeio pelo jardim pode ser estimulante para a invenção de canções sobre as flores, ou ainda que uma criança maior poderia encontrar grande satisfação com a 
tarefa de criar uma canção para o aniversário do pai. A improvisação ao instrumento também deve ser encorajada desde o início do contato da criança com o objeto. Para a educadora (1939), a única condição para a atividade criativa, neste caso, é o conhecimento do uso adequado do instrumento, de maneira a tomá-lo como um recurso propriamente musical.

Em tom de defesa da prática criativa direcionada àqueles que não veem valor nas produções das crianças, porque demasiadamente distintas dos padrões estéticos de produção dos adultos, Coleman (1939) se vale da comparação com a abertura já vista, à época, no campo das artes visuais. Em suas palavras:

Alguns críticos dos esforços criativos "não musicais" das crianças têm sido eloquentes em desaprovar os resultados simples e não habilidosos. Esse criticismo parece indicar uma falta de familiaridade com a imaturidade natural das primeiras formas artísticas infantis. Para serem coerentes, eles não deveriam permitir que crianças pequenas desenhassem, à sua maneira característica, formas como pessoas, animais, árvores, flores, etc., para evitar que suas representações brutas, grotescas e irreconhecíveis impeçam o desenvolvimento de sua apreciação da beleza da figura humana e outras formas da natureza. O pai mediano de hoje em dia reconhece o valor da experiência original em desenho ou pintura, não importando quão bruta ela seja; e o mesmo valor existe no esforço criativo da criança no campo da música. A intenção e o esforço de produzir algo original (mesmo que o resultado seja pobre) são muito mais profícuos no processo de crescimento da criança que a manipulação perfeita de modelos criados por outrem (COLEMAN, 1939, p. 47).

Notemos, pois, que não existe uma valorização a priori do produto da composição das crianças, mas a compreensão de que a atividade de manipulação original de materiais - sejam eles próprios às artes visuais ou musicais - é essencial para a educação, sendo seu resultado de menor importância. A atividade criativa, segundo a autora (1939), tende a impulsionar o interesse, o que é condição para o desenvolvimento.

Se o gosto de alegria criativa em manipular materiais musicais pode despertar um interesse que, até então, era negado obstinadamente e dar um ímpeto para novas explorações na arte, importa quão rudimentares esses primeiros sons possam ser? A verdadeira educação não está preocupada com a sutileza ou a perfeição das primeiras produções das crianças; ela está preocupada com a direção que o crescimento está tomando (COLEMAN, 1939, p. 48, grifo no original) 
Não caberia aqui uma análise do conceito de interesse, nem em sua concepção deweyana, nem em suas atualizações frequentes na área da educação. Não obstante, parece-nos digno de nota que, em um dos artigos onde Surette (1930) se opõe ao destaque dado à expressão infantil na educação musical de seu tempo, ele o faça de maneira a sugerir que seria muito mais profícuo para o campo tomar como centro o interesse das crianças. Todavia, para este educador (SURETTE, 1930), o interesse resulta da adequação da criança a uma atividade pertinente à ela, como, por exemplo, o prazer resultante da conjunção das necessidade de cantar e de adquirir novas habilidades.

Em Coleman (1939), o interesse é fomentado pela criação e não se restringe às aulas de música. À família cabe criar situações para as crianças improvisarem e comporem, além de ter tempo disponível e predisposição estética para apreciar as invenções infantis. De maneira a ajudar aqueles que não têm formação musical, Coleman divulga o sistema de notação numérica já apresentado aqui. Assim, as criações melódicas feitas em casa poderiam ser anotadas com o auxílio de qualquer adulto.

Para além do fomento às práticas criativas, outro grande tema perpassa a obra. Coleman (1939) advoga por uma postura musical ativa, tanto das crianças quanto de seus familiares, em contraposição ao hábito que vinha se propagando, a saber: a escuta de música gravada. Considerações acerca dessa mudança nas formas de acesso à música estão presentes também nas publicações das revistas analisadas, tanto nos Estados Unidos quanto na Europa. De maneira geral, coexistem o entusiasmo concernente à expansão das possibilidades de apreciação por meio da radiodifusão e da comercialização de gravações, e a desconfiança em relação à suposta passividade proporcionada pelo acesso facilitado à música "pronta".

Coleman (1939) reconhece que a tecnologia de gravação e difusão representa um grande avanço, sobretudo para aqueles que estão impossibilitados geograficamente de ter acesso a performances musicais. No entanto, a educadora também considera que o acesso não depende apenas da difusão física das obras, mas demanda interesse, e a educação, tanto em casa quanto na escola, deve ter um papel fundamental para a possibilidade de fruição.

A autora sugere que a música gravada vinha sendo vista como uma substituta das práticas vocais e instrumentais. Isso seria, na verdade, mais um desdobramento da 
profissionalização, que separa produtores e consumidores de música. Em suas palavras: “[...] nós nos tornamos preguiçosos e adquirimos o hábito de deixar outras pessoas fazerem nossa música em nosso lugar; e, dessa maneira, nós que não somos profissionais perdemos mais do que ganhamos com o grande aumento na quantidade de música" (COLEMAN, 1939, p. 6). O crescente acesso à música gravada exacerbaria essa distinção de funções.

No que diz respeito à formação de crianças, Coleman (1939) dá exemplos de pais e mães que viam essas tecnologias como meios de substituição ou equivalência da educação musical. Destacamos um trecho em que a educadora advoga pela primazia da prática, especialmente da composição, em resposta aos pais de uma garota. Estes não veem motivos para que sua filha tenha aulas de música, dado que rádios e vitrolas proveem música de qualidade muito superior àquela tocada pela criança. A resposta de Coleman defende a impossibilidade de tal substituição, enfatizando mais uma vez que o objetivo da educação musical é o desenvolvimento da criança:

\begin{abstract}
Antes de mais nada, os pais de Hilda precisam saber que escutar música não substituirá nunca o ato de fazê-la. Mesmo que as "pobres tentativas" de Hilda não sejam tão agradáveis quanto uma sinfonia de Brahms, elas têm mais poder sobre sua personalidade e sobre sua vida emocional que qualquer música externa, desde que seu interesse esteja por trás de seus esforços. A música que Hilda faz é algo pessoal e íntimo, e se torna parte de sua bagagem para a vida, o que não lhe pode ser roubado. Nenhuma música externa, mesmo que grande, pode prover a alegria que a produção de uma simples composição dá à criança. Próxima à importância de fazer música está a de escutar música, porém, entre as duas há um mundo de diferença (COLEMAN, 1939, p. 5 - 6)
\end{abstract}

Ainda sobre os hábitos de escuta, algo digno de nota é uma passagem onde Coleman trata dos sons da natureza. Assim como em relação à música, a escuta desses sons deveria ser incentivada desde a infância. Coleman descreve uma série de sons de uma paisagem natural, equiparando-os em beleza à música e lamenta que muitas pessoas não estejam atentas a eles, pois não foram ensinadas "a amar a Natureza com seus ouvidos da mesma maneira que o fazem com os outros sentidos" (COLEMAN, 1939, p. 95). A incorporação da escuta da paisagem sonora como hábito a ser 
cultivado, mesmo que não tenha ganhado proeminência nem maior desenvolvimento na obra da autora, aparece-nos como mais um traço de originalidade de seu trabalho.

A escuta da natureza também pode ser lida como uma espécie de oposição ao avanço tecnológico. No momento em que o acesso à música alcança um nível quantitativo nunca antes imaginado, Coleman atenta para a necessidade de ouvir sons cuja produção não é artificial e estão ao alcance de todos sem mediação.

A popularização do rádio e da música gravada em suportes como discos é acompanhada pela popularização de um repertório específico: a música popular industrializada. Coleman (1939) é, de uma maneira geral, aberta a todo repertório, mas apresenta duas ressalvas em relação ao que as crianças ouvem.

A primeira ressalva diz respeito ao que ela considera como a afetação da voz característica da música de má qualidade veiculada pelo rádio, contudo, a autora não dá exemplos de tal música nem de tal modo de cantar. Ela defende que as crianças cantarão o que estiverem acostumadas a ouvir e suas considerações sobre a voz tratam do cuidado que deve ser tomado nas referências fornecidas às crianças. A segunda ressalva trata do que a autora denomina "música hiper-rítmica" (COLEMAN, 1939, p. 99). Como definição, Coleman afirma se tratar das músicas nas quais o ritmo é o elemento predominante, o que as torna de fácil assimilação, pois afetam "mais os músculos que a mente" (COLEMAN, 1939, p. 99). A autora não considera essa música problemática a priori e afirma que tanto o jazz como o swing - dois dos exemplos dados por ela como música hiperrítmica moderna - têm seu valor, servindo a momentos alegres. Outros exemplos dados são músicas marciais e cantos de trabalho, sendo ressaltada sua função social. Contudo, a educadora avalia como preocupante a grande profusão de oferta de músicas as quais, segundo ela, não exigem algum esforço ou atenção do ouvinte.

Há momentos em que isso pode ser de grande valor para a saúde e para a felicidade, mas quando a experiência de alguém é limitada a tal tipo de música, há vastas áreas de respostas musicais possíveis e necessárias para uma completa satisfação musical, tanto intelectuais quanto emocionais, que permanecem intocadas e não são desenvolvidas (COLEMAN, 1939, p. 100)

Assim, mesmo que de maneira moderada, Coleman (1939) se posiciona em relação à crescente indústria cultural e à mudança de hábitos musicais aí implicada. Seja defendendo a prática musical em oposição à suposta passividade propiciada pela 
facilitação do acesso à música gravada, seja pelos comentários acerca do repertório difundido, a autora abordava temas importantes para a reflexão sobre a educação musical de seu tempo. Destacamos que, em suas considerações sobre o repertório, Coleman (1939) não restringe o material a ser utilizado para apreciação em ambiente educacional. Ao contrário, quando traz à discussão a música recente e amplamente difundida pelo rádio, o faz com vistas a atentar para a necessidade de pluralidade na formação de referências para as crianças, possibilitando "experiências musicais que dão um conceito mais amplo da arte" (COLEMAN, 1939, p. 101).

As considerações sobre os conteúdos identificados na revista Progressive Education e sobre os trabalhos de Satis Coleman nos permitem compreender melhor como o ideário do movimento progressista se desdobrou em discursos e práticas de educação musical no período estudado. Dentre todos os conteúdos abordados, atentamos principalmente para o pioneirismo das reavaliações sobre os processos criativos infantis, aspecto que expressa a coerência da área com o projeto pedagógico de renovação escolar estadunidense.

Em seguida, nos debruçaremos sobre os materiais concernentes ao movimento pedagógico francês, visando compreender as especificidades de tal cenário, bem como as marcas de circulação de ideias em âmbito internacional. Interessa-nos, sobretudo, evidenciar o lugar ocupado pelas práticas criativas nos materiais que tratem de educação musical, além dos demais traços de pioneirismo e as problemáticas às quais se dedicaram os educadores franceses no período focalizado. 


\section{Capítulo 3 - Educação musical e renovação escolar na França}

\subsection{Novidades continentais e locais}

Se o caráter internacional dos movimentos de renovação escolar é fator importante para sua compreensão, ele ganha ares determinantes em se tratando de grupos europeus. Isso porque os esforços de associar os diferentes agentes envolvidos em experimentos pedagógicos pelo continente datam ainda do final do século XIX e têm, com a fundação do Bureau International d'Éducation Nouvelle, em 1899 por Adolphe Ferrière, um primeiro órgão informativo e de recenseamento de escolas inovadoras. A criação do BIEN teve como incentivador Edmond Demolins (HAMELINE, 2004), que havia fundado recentemente a École des Roches e cuja influência inglesa era inequívoca ${ }^{59}$. Em 1912 é fundado o Institut Jean Jacques Rousseau em Genebra, ao qual o BIEN seria anexado em 1923. A fundação desse Instituto, por Edouard Claparède, expressa uma via de formação e pesquisa científica do cenário europeu de renovação pedagógica.

Diversos desdobramentos se seguem no que concerne à estruturação de relações entre os envolvidos, seja no âmbito científico, como na presença de educadores e intelectuais escolanovistas em instituições superiores, seja nas relações com o poder público, visto que o ideário de renovação era fonte para reformas de sistemas de educação. Dentre as formas de colaboração entre renovadores, nos interessam, sobremaneira, as atividades da Ligue Internationale pour L'Éducation Nouvelle; e da associação La Nouvelle Éducation, ambas fundadas em 1921. A primeira nos parece fonte frutífera pelo caráter cosmopolita, congregando agentes de diversos países em espaços de discussão e divulgação de práticas pedagógicas, tais como conferências e revistas. A segunda, por sua vez, por ações da mesma natureza,

\footnotetext{
${ }^{59}$ Demolins publicou, em 1897, o texto À quoi tient la superiorité des Anglo-Saxons?, cujo sucesso se desdobrou na fundação da École des Roches em 1899. Em um contexto de tensão política, militar e comercial entre França e Inglaterra, Demolins se dedicou a comparar traços sociais dos dois países no sentido de valorizar os estrangeiros. Segundo Raillon (2000), quinze mil exemplares da obra foram vendidos em poucos meses, tornando conhecidos os primeiros experimentos escolanovistas ingleses aos franceses. Enfatizando a área da educação, tinha como referências Cecil Reddie, fundador da Abbotsholme School, escola inglesa pioneira que iniciou suas atividades no ano de 1889, e John Haden Badley, que trabalhou com Reddie até fundar sua própria escola em 1893, a Bedales School.
} 
mas realizadas em âmbito local, atuando sobretudo no contexto francês, sem deixar de ecoar influências estrangeiras.

A fundação da LIEN se deu por ocasião do Congresso Internacional de Educação de Calais, cidade do norte da França. Segundo Condette e Savoye (2016), a realização deste evento marca uma retomada da internacionalização de assuntos sociais e científicos que vinha ocorrendo desde a segunda metade do século XIX por meio de eventos internacionais e exposições universais, interrompida em razão da Primeira Guerra Mundial. Ele marca o início de uma série de outros congressos organizados pela Liga, que passa também a publicar três periódicos, a saber: The New $E r a^{60}$, publicação para leitores anglófonos; Das werdende Zeitalter, em língua alemã e dirigida por Elisabeth Rotten em Berlim; e Pour l'Ère Nouvelle, dirigida em Genebra por Adolphe Ferrière.

Para além de sua importância histórica inconteste, o Congresso de Calais nos desperta especial interesse, pelo assunto tematizado, a saber: “A expressão criativa da criança". Nós nos dedicaremos aqui à elaboração de algumas considerações em relação às discussões que animaram o evento, visto que sua temática está diretamente ligada à presente tese. Partindo da observação de como a comunidade de militantes europeus pela educação nova se comportava em relação ao tema supracitado naquele momento, apresentaremos, em seguida, os conteúdos da revista francesa que constitui uma das fontes principais de nosso trabalho, La Nouvelle Éducation.

\subsection{O Congresso Internacional de Calais (1921)}

A partir da hipótese de que os processos criativos infantis tiveram valorização pioneira nos movimentos de renovação escolar do início do século XX, o título do Congresso Internacional no qual se estabelece a Liga Internacional pela Educação Nova nos aparece como indicador de respostas às questões de nossa pesquisa. Se o pensamento escolanovista teve como desdobramento as práticas criativas em educação musical, como isso se deu? Essa análise depende, sobretudo, das ideias de

\footnotetext{
${ }^{60}$ Essa publicação era, até então, a revista Education for the New Era: An International Quarterly Journal for the Promotion of Reconstruction in Education. Dirigido por Beatrice Ensor e Alexander Neill, o periódico começou a ser publicado em 1920 pela New Education Fellowship, organização originada em meio a fraternidades teosóficas inglesas (CONDETTE; SAVOYE, 2016).
} 
criação e de infância discutidas no cenário, bem como da identificação de como tais ideias tomavam forma de prática pedagógica.

Cabe-nos, antes, atentar para duas considerações sobre esse evento. A primeira consideração diz respeito ao caráter internacional do Congresso. A ideia de que se tratava de um evento internacional é verdadeira, na medida em que, como já observado anteriormente, retoma um esforço de circulação impedido temporariamente pela Primeira Guerra Mundial. Condette e Savoye (2016) defendem que, até esse momento, o movimento tinha caráter muito mais multinacional do que internacional, visto que se desenvolvia em diversos países, porém não contava com verdadeira integração, a despeito dos esforços já realizados por Ferrière. Segundo os autores (2016), apenas Maria Montessori já havia conseguido gerar uma rede coerente com a tradução de seus escritos e com sua iniciativa de formação de professores.

Mesmo que seja inegável a abertura para a cooperação internacional representada pelo evento, Brehony (2004) atenta para a predominância de ingleses na ocasião. Isso se expressa, segundo ele (2004), pelo fato de que, mesmo que se diga que o Congresso atraiu participantes de 14 países diferentes, os ingleses eram maioria entre os conferencistas e o público de ouvintes consistia, predominantemente, de professores de escolas de educação básica inglesas. A própria localização escolhida para o evento, ainda que em território francês, era de fácil acesso àqueles que vinham da Inglaterra ou da Bélgica, notam Condette e Savoye (2016). A essas considerações, acrescentamos que a direção da Liga fundada na ocasião foi incumbida à Beatrice Ensor, francesa de nascimento, mas que vivia na Inglaterra e lá estava envolvida em organizações relacionadas à infância e à teosofia, tendência dominante entre educadores ingleses (BREHONY, 2004).

Salientamos, contudo, que, ao observar as 22 conferências proferidas no Congresso (tab. 8), notamos que elas estavam divididas de maneira equânime, entre as línguas inglesa e francesa. Atentamos, da mesma maneira, que a produção em língua francesa expressa a circulação de ideias e experimentos oriundos não apenas da França, mas, especialmente, da Suíça - neste momento, Genebra já havia se estabelecido como ponto de referência em razão dos trabalhos de Ferrière e da presença do Institut Jean Jacques Rousseau - e da Bélgica, representada no evento por Ovide Décroly. 


\begin{tabular}{|c|c|}
\hline \multicolumn{2}{|c|}{ Conferências } \\
\hline \multicolumn{2}{|l|}{ The liberation of creative faculty by education } \\
\hline & L. Haden Guest, M. C. L.C. C \\
\hline \multicolumn{2}{|l|}{ The french child at home and at school } \\
\hline & Cloudesley Brereton \\
\hline \multicolumn{2}{|l|}{ The Montessori method } \\
\hline & C. A. Claremont, B. S. \\
\hline \multicolumn{2}{|l|}{ Craftsmanship and creative education } \\
\hline & Henry Wilson \\
\hline \multicolumn{2}{|l|}{ La Co-éducation } \\
\hline & Mlle. J. Decroix \\
\hline \multicolumn{2}{|l|}{ La Co-éducation } \\
\hline & H. Baillie-Weaver, L. L. B \\
\hline \multicolumn{2}{|c|}{ L'enfant, est-il capable de puissance créatrice? } \\
\hline & R. Nussbaum \\
\hline \multicolumn{2}{|l|}{ The abolition of authority } \\
\hline & A. S. Neill, M. A. \\
\hline \multicolumn{2}{|l|}{ A liberal education in elementary schools } \\
\hline & Miss R. A. Pennethorne \\
\hline \multicolumn{2}{|c|}{ Une expérience de programme primaire avec activité personnelle de l'enfant } \\
\hline & Dr. Decroly \\
\hline \multicolumn{2}{|l|}{ Application de la méthode du Dr. Decroly } \\
\hline & Mlle. A. Hamaïde \\
\hline
\end{tabular}


L'École active

Dr. Adolphe Ferrière

Les écoles nouvelles à la campagne

Dr. Adolphe Ferrière

Self-government and the growth of character

E. A. Craddock, M. A.

La psychanalyse

Dr. James Young

The cultural value of analytical psychology

Dr. James Young

L'art et l'enfant

Frank Choisy

The value of drama in education

Miss I. M. Pagan

Some recent developments in intelligence tests

Miss Elsa Walters, M. A.

The schools of tomorrow

Mrs. Beatrice Ensor

La valeur éducative du scoutisme

J. Loiseau

Conférence de clôture

Professeur A. Beltette 
Tabela 8 - Lista de conferências e conferencistas tal como publicada em The creative selfexpression of the child: a report of lectures (THE NEW ERA, 1921, p. VII - VIII)

A segunda observação a ser feita sobre o Congresso em questão nos leva ao seu conteúdo. Este era claramente eclético, segundo Brehony (2004), mas já apontando para a importância da psicologia como campo basilar, mesmo que tomada de maneiras discrepantes, como alinhada à psicanálise por uns, e a testes de mensuração de inteligência, por outros.

Segundo Condette e Savoye (2016), por mais que o título do evento tenha sido L'expression créatrice de l'enfant, esse tema não foi sistematicamente abordado pela maioria dos conferencistas. Para os autores, o congresso foi tomado pelos envolvidos como um espaço para "apresentar suas concepções de uma mudança necessária da educação, sem grandes preocupações em ligá-las à temática da criatividade infantil”" (CONDETTE; SAVOYE, 2016, p. 64). Entretanto, no escopo da presente tese, mesmo que a temática não tenha sido explorada de maneira cautelosa por todos os conferencistas, a sua escolha como título do Congresso, bem como as temáticas que intitulam congressos subsequentes da Liga ${ }^{61}$, nos permite considerar que a abertura para as práticas criativas das crianças, mesmo que não constitua ainda tema fulcral e de consenso no cenário, já estava em pauta e começava a estimular as trocas intelectuais e as práticas pedagógicas. Observemos, então, como essa temática é abordada em três conferências que se aproximam de nosso foco.

\subsubsection{A criação e a expressão infantis tematizadas no Congresso de Calais}

Apesar do assunto escolhido para tematizar o congresso não ter sido objeto de dedicação atenta de todos os conferencistas, identificamos exposições que o tratam e que nos permitem elaborar algumas considerações. A conferência de maior destaque neste sentido foi aquela proferida por Robert Nussbaum - diretor e fundador da École-Foyer des Pléiades Blonay, na Suíça -, intitulada L'Enfant est-il capable de puissance créatrice? Ao colocar a capacidade criadora da criança em questão, Nussbaum vai diretamente ao tema e faz dele o verdadeiro problema a ser discutido em sua contribuição. Um segundo artigo que nos interessa é aquele resultante da

${ }^{61}$ Dentre os quais, destacamos os seguintes: "A atividade espontânea da criança”, Heidelberg, 1925 e "O significado da liberdade em educação”, Locarno, 1927. 
conferência de Frank Choisy - diretor e fundador do Conservatoire Populaire de Musique, em Genebra, na Suíça -, de título L'art et l'enfant. Nessa conferência, o tema da criação na infância não é tratado com a mesma atenção que naquela de Nussbaum, no entanto, ele aparece de maneira secundária, amparando uma exposição mais voltada a relatos de trabalho de ensino de música com crianças. Mesmo que trate de escola de música, podemos observar em sua fala alguns indícios de como a criação infantil e a prática musical na infância eram concebidos no cenário do congresso. Consideramos, ainda, uma das palestras de Adolphe Ferrière, aquela intitulada L'école active. Esse texto traz também o assunto da criação de maneira breve, mas nos possibilita estabelecer conexões com os artigos precedentes e manifesta alguns pontos do pano de fundo epistemológico do momento.

A primeira consideração a ser feita é em relação aos termos criação e expressão, ambos debatidos pelos três autores. As tentativas de esclarecer definições para tais termos apresentam-se como condição fundamental de abordagem do tema. Tanto Nussbaum (1921) quanto Choisy (1921) são enfáticos em negar que o termo criação seja adequado ao que as crianças fazem. A criação, para esses autores, está ligada à ideia de obra de arte como produto elaborado e portador de traços específicos de uma cultura, realizado através da ação refletida de um indivíduo. Choisy (idem) sugere que, mesmo para os adultos, tal tarefa não é fácil.

Ferrière (1921) não se desdobra sobre o termo criação, referindo-se a ele de maneira breve, como caminho para chegar aonde pretende. Ele afirma que, em um sentido estrito, diz-se que a criança não cria verdadeiramente, no entanto, em um sentido amplo e aproximando-se da espontaneidade característica da ação infantil, pode-se falar em expressão criativa. Também Nussbaum opera tal substituição, afirmando que "nós falamos frequentemente de criação onde deveríamos falar apenas de expressão" (NUSSBAUM, 1921, p. 52). No entanto, Ferrière (1921) leva em consideração - e por isso não abandona o adjetivo ao lado de expressão - que a novidade deve ser medida em relação à criança. A originalidade da expressão infantil diria respeito ao seu próprio desenvolvimento, não ao desenvolvimento histórico e cultural de uma linguagem artística ou da ciência.

Os autores abandonam, assim, cada um à sua maneira, o termo criação, mas não abandonam o assunto. Ao contrário, a reflexão sobre o mesmo se dá a partir da tentativa de esclarecimento dos termos que lhe seriam mais pertinentes. Dado que, para estes autores, não cabe à criança criar, as argumentações são construídas de 
maneira a apontar suas concepções de infância e da educação ideal a ela correspondente.

Neste sentido, o texto de Nussbaum é bastante interessante. Logo no início de sua conferência, o autor mostra-se consciente das diversas imagens de infância e de como estas constituem as bases para a justificação da ação de adultos em relação às crianças de uma maneira geral e, mais especificamente, para a pedagogia. Em suas palavras: "[...] podemos constatar que as apreciações dos adultos sobre as crianças se modificaram, através dos séculos, segundo as flutuações das ideias sociais, étnicas ou mesmo políticas; essas apreciações, inspiradas por outros aspectos que não a observação da criança, determinaram diversos tipos pedagógicos" (NUSSBAUM, 1921, p. 45). Ele assume, então, a crítica a uma visão da infância que a subjuga a exigências arbitrárias e artificiais e que se mostra em métodos de ensino rigorosos, cuja premissa é a falta de valor próprio da criança. No entanto, Nussbaum não dá adesão ao que ele acredita ser uma visão demasiado ingênua da infância em voga naquele momento. Segundo ele (idem), a tirania dos métodos antigos levaram a um exagero, por parte de seus contemporâneos, da crença na excelência da natureza infantil. Nussbaum acredita que a alta da valorização da expressão infantil estaria ligada à espontaneidade. Uma vez que os adultos a perdem em um modo de vida guiado por necessidades, a expressão espontânea da criança se lhes aparece como um "paraíso perdido" que gostariam de preservar para si mesmos (Id., p. 54).

Nussbaum defende que a expressão infantil é fundamental para o desenvolvimento das crianças, compreendendo também a necessidade de imitação e repetição. Ele coloca como incumbência dos educadores de seu tempo a liberação da expressão infantil tal qual ocorreu, anteriormente, a liberação dos movimentos das crianças a partir da supressão do hábito de enfaixá-las. O autor não nega a importância das atividades expressivas no desenvolvimento das crianças, contanto que não se valorize a "simplicidade" da espontaneidade de maneira ingênua (Ibid.).

Apesar de ser apresentado como fundador e diretor de uma escola, Nussbaum não toca diretamente em assuntos de prática pedagógica ou de gestão escolar. Choisy (1921), por sua vez, inicia sua conferência com algumas palavras sobre arte e criação, mas logo passa a considerações sobre seu trabalho no Conservatório Popular de Genebra. Quando nega a capacidade criativa na infância, afirma, por outro lado, que essa é uma fase movida pelas "forças ativas" e que o papel da educação seria despertá-las. Não esclarece, no entanto, o que são e como agem essas forças, apenas 
afirma que elas garantem uma infância feliz e inteligente artisticamente. Temos uma amostra um pouco mais clara, então, quando se dedica aos "resultados práticos" do trabalho que "experimentava" há 10 anos (Idem, p. 154). Esse relato não nos interessa precisamente, pois nosso foco se dirige à escola de educação básica, no entanto destacamos que as crianças faziam sobretudo trabalhos de integração das linguagens artísticas, chamados de jogos musicais; que Choisy valorizava as descobertas e soluções pessoais das crianças - suas "trouvailles" (Idem, p. 154) -; e, ao tratar de um programa apresentado pelas crianças, relata uma sinfonia de sua autoria em que há também cenas nas quais, por exemplo, um personagem pianista, muito cansado, cai no piano e faz um barulho forte. Há ainda um movimento no qual o grupo faz uma espécie de paisagem sonora. Quando comenta o trecho da obra intitulado Na rua, o autor o descreve como "música quase de barulhos" e diz que "a flexibilidade dos meus [dele] pequenos músicos por vezes me [o] encheu de admiração" (Idem, p. 162). Por mais que o autor seja enfático quanto à impossibilidade criativa na infância, sua atividade pedagógica apontava para aberturas significativas no ensino em conservatório para crianças.

Ferrière, ao defender a expressão criativa da criança - no lugar de criação -, recorre a argumentos científicos. Já no início de sua exposição faz referência às escolas experimentais que visitou na França e na Alemanha ainda no final do século anterior. Esses empreendimentos o entusiasmavam, mas Ferrière acreditava que lhes faltava "ossatura científica" (FERRIÈRE, 1921, p. 94); então, decidiu procurar na psicologia as bases para um educação ativa. Sua conferência se desenvolve a partir de uma grande quantidade de referências, dentre as quais encontram-se Stanley Hall, C. G. Jung, William James, entre outros. Uma referência notável no cenário e que também já havia aparecido de maneira tácita no texto de Nussbaum, é Henry Bergson $^{62}$. Há ainda menções à psicologia ligada diretamente a aplicações didáticas, como nos trabalhos de Maria Montessori e Ovide Decroly, que são exemplares para Ferrière.

\footnotetext{
${ }^{62}$ Além do aporte bergsoniano presente nas conferências que consideramos aqui, é notável que um dos conferencistas, Cloudesley Brereton, fosse mais famoso à época como tradutor de Bergson para o inglês que como inspetor de educação. Brehony (2004) afirma que a abordagem bergsoniana - na conferência de Ferrière, especificamente o conceito de élan vital e o livro A evolução criadora (1907) -, à época, não era considerada de valor científico inconteste. No entanto, suas ideias encontravam grande aceitação no círculo intelectual. Um exemplo disso é o fato de que, em 1927, Bergson tenha sido laureado com o Prêmio Nobel de Literatura.
} 
De maneira geral, o pano de fundo teórico esboçado por Ferrière o levava a defender uma abordagem pedagógica que valorizasse a espontaneidade da criança, pois esta estaria intimamente ligada, seguindo a teoria de Bergson, ao élan vital, essência de todo crescimento e de todo progresso (FERRIÈRE, 1921). Em suas considerações sobre a expressão criativa, afirma que essa se constitui de cinco elementos psicológicos, a saber: "[...] a espontaneidade; a afetividade (emoção); o interesse (objetivo: ideia a exteriorizar); a atividade; a novidade (em oposição à imitação pura e simples)" (Id., Ibid., p. 98). Contudo, o tema não é tratado de maneira pormenorizada pelo autor. A vasta gama de referências é apresentada por Ferrière de maneira a fundamentar sua proposta de Escola Ativa. Sua participação no congresso marca o início de trabalho intenso e de protagonismo na LIEN, principalmente na década de $1920^{63}$.

Dentre as conferências, aquela de Nussbaum é, de fato, a única onde o tema do congresso ocupa espaço central. Entretanto, sua abordagem mesmo que breve em outros textos nos permite afirmar que os limites e as condições para pensar a criação na infância já estavam em debate e já estimulavam a prática pedagógica. No início do movimento de cooperação internacional, esse tema não era ignorado, ao contrário, mobilizava argumentos em relação às novas concepções de infância e de educação que estavam sendo engendradas. A seguir, passamos às observações sobre o ideário pedagógico e seus desdobramentos no ensino de música em material específico concernente à associação francesa La Nouvelle Éducation.

\subsection{La Nouvelle Éducation}

Em janeiro de 1921 - portanto, alguns meses antes do Congresso de Calais, que se passou em agosto do mesmo ano - Madeleine Guéritte e Roger Cousinet fundam a associação La Nouvelle Éducation. Na ocasião do Congresso, nenhum dos dois educadores esteve presente. A ausência é interpretada por Gutierrez e Savoye (2018) como escolha, por parte de Guéritte e Cousinet, de uma via distinta daquela que vinha se abrindo a partir das ações de Ferrière e dos educadores ligados à teosofia na Inglaterra.

\footnotetext{
${ }^{63}$ À centralidade de Ferrière para a publicação francófona da LIEN, a revista Pour l'Ėre Nouvelle, se substitui aquela do Groupe Français d'Éducation Nouvelle, que assume a administração da revista em 1929 e sua redação em 1932 (HAENGGELI-JENI; HOFSTETTER, 2011).
} 
Quando dos anos iniciais da associação, esta publicava um boletim na revista L'Éducation, dirigida por Georges Bertie. Em janeiro de 1924, a associação passa a ter uma publicação independente, mensal - exceto nos meses de agosto e setembro -, o que se estende regularmente até o ano de 1939. Em nossa pesquisa, tomamos como fonte as publicações independentes, o que compreende os materiais publicados entre o boletim número 21 e o de número 177. As atividades são interrompidas com a Segunda Guerra Mundial e, após a Liberação, em 1945, ambos fundam uma nova associação, L'École Nouvelle Française, na qual Guéritte não se engaja e que será dirigida por Cousinet e François Chatelain nos anos que seguem (GUTIERREZ, 2011).

Os princípios da associação, bem como suas atividades e demais conteúdos, eram veiculados pela revista que levava o mesmo título do grupo. Na primeira página de cada número, podemos ler a apresentação, bem como observar que, apesar da recorrência de atividades na cidade de Paris, os diretores não habitavam a capital francesa (Fig. 9). O texto de apresentação informa:

Nossa associação tem por objetivo reunir todos os educadores decididos a favorizar a atividade pessoal das crianças na França, seja na escola ou na família. Seu propósito é ajudar estes educadores, dar a conhecer e repetir suas experiências, de maneira que o trabalho de cada um possa beneficiar a todos e que se faça o mais rapidamente a transformação necessária de nossos métodos de educação (NOTRE, 1924, p. 1)

Uma característica fundamental da associação e, consequentemente, de sua revista, é o foco na prática pedagógica. A revista é apresentada como meio para a veiculação de experiências educacionais e isso se explica pela inclinação prática e experimental de seus diretores. Guéritte tem influência montessoriana evidente e Cousinet, por sua vez, buscava uma "pedagogia científica", baseada na observação das crianças orientada pela psicologia, e desenvolvida a partir da interação entre pares (GUTIERREZ, 2011, p. 230).

Um exemplo desse direcionamento é o comentário veiculado pela revista e assinado pelo editorial após o congresso internacional da LIEN de 1932, em Nice. Este foi o evento mais politizado, tendo por pano de fundo a ascensão do 
nacionalismo na Europa ${ }^{64}$. O editorial denuncia, dois meses depois, que o congresso não representou grandes avanços em assuntos propriamente pedagógicos, visto que seus conferencistas se ocuparam preferencialmente de temas sociais $\left(\mathrm{LE} \mathrm{VI}^{\mathrm{e}}, 1932\right)$. Acrescenta-se, ainda, uma sugestão para o congresso seguinte, que se passaria em 1935. O editorial afirma que as transformações na educação avançariam muito mais rapidamente se "cada conferencista e cada congressista fosse passar ao menos 24 horas em um grupo de cerca de 30 crianças pequenas vivendo em liberdade" (LE VI 1932, p. 156).

\section{La Nouvelle Éducation}

Notre association a pour objet de réunir tous les éducateurs décidés à favoriser en France l'activité personnelle des enfants, soit à l'école soit dans la famille. Son but est d'aider ces éducateurs, de faire connaître et de répéter leurs expériences afin que les travaux de chacun puissent profiter à tous, et que se fasse plus vite la transformation nécessaire de nos méthodes d'éducation.

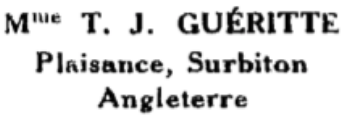

M. Roger COUSINET
Juvisy (S.-et-O.)

Figura 9 - Excerto da primeira página do número 21 de janeiro de 1924. Este texto de apresentação da associação é reproduzido a cada publicação

\footnotetext{
${ }^{64}$ Haenggeli-Jenni e Hofstetter (2011) apontam uma grande diferença entre as duas décadas da revista Pour l'Ére Nouvelle, publicação da LIEN em francês. Para as autoras, a revista exprime uma virada social do movimento, o que fica evidente no Congresso de 1932, realizado em Nice. Em suas palavras: "Alguns conferencistas [...] fazem um balanço desfavorável depois de dez anos de esforços empreendidos pela Liga; se eles reconhecem o valor das mudanças realizadas, também mostram os limites e convidam os amigos da infância a mudar de orientação - levando mais em conta as dimensões sociais e, de fato, também políticas e econômicas - para tornar a educação mais operacional na sua missão de transformar a sociedade" (HAENGGELI-JENNI; HOFSTETTER, 2011, p. 155). No que concerne à nossa área, foi neste Congresso que se iniciou o contato entre educadores franceses e ingleses que viria a se desdobrar na criação de grupos de música de câmara - mais especificamente, flauta -, as Guildes des Pipeaux. Esses grupos tiveram atividade intensa na década de 1930 e serão objeto de nossas considerações adiante. Acrescentamos, ainda, que no ano de 1932 faleceram C. Reddie, fundador da Abbotsholme School, na Inglaterra, e G. Kerschensteiner, educador de Munique, fundador das Arbeitschulen, e organizador de uma exposição de desenhos de crianças já e 1902. Na seção de notícias da edição de número 104 de La Nouvelle Éducation, datada de abril de 1932, são comunicadas as mortes dos dois educadores, apresentados como pioneiros dos movimentos em seus respectivos países.
} 
A trajetória de Roger Cousinet $(1881$ - 1973) é marcada pela pesquisa em proximidade com a realidade da sala de aula, tendo ele atuado em diversos cenários, como a escola de educação básica e os meios de produção de conhecimento intelectual. Seus interesses passam da psicologia à sociologia como áreas fundantes das ciências da educação. Ao observar as crianças com uma postura científica, Cousinet considera que existem diferenças consideráveis entre as formas de conceber a realidade por adultos e crianças. Assim, problematiza a transmissão de conhecimento tal qual centrada no professor e sugere que a aprendizagem seria otimizada se ocorresse entre pares, em trabalhos em grupo. A preocupação sobre as possibilidades das trocas sociais entre crianças passa, então, a ocupar os trabalhos de Cousinet, congregando psicologia e sociologia, em busca de uma pedagogia cientificamente embasada (GUTIERREZ, 2011).

Madeleine Guéritte (1881 - 1948), por sua vez, não teve formação específica em educação, psicologia ou sociologia, áreas fundamentais nos movimentos de renovação escolar. Ainda jovem, Madeleine Aubry é pianista ativa e participa, junto a seu irmão, Georges Jean-Aubry - musicólogo, escritor e crítico literário -, do Círculo de Arte Moderna do Havre, fundado em 1906. Em 1912, casa-se com Tony Jules Guéritte em Londres. Instalada na Inglaterra, Madeleine cria junto a seu marido a Sociedade de Concertos Franceses em Londres, divulgando a música francesa contemporânea em território inglês (GUTIERREZ; SAVOYE, 2018). É na Inglaterra também que Madeleine Guéritte inaugura sua trajetória de engajamento pela causa da educação, participando da associação britânica New Ideals in Education e iniciando os trabalhos de tradução que conectaram os cenários francófonos e anglófonos, o que é marca também de sua atividade na La Nouvelle Éducation. Em nosso trabalho, sua figura se mostra de profundo interesse pois congrega a área da música e a circulação de ideias, sendo Madeleine pianista e tradutora.

A publicação que Madeleine Guéritte e Roger Cousinet dirigiram entre 1921 e 1939, primeiro como boletim em L'Éducateur e logo de maneira independente, tinha como características centrais a influência de produções em língua inglesa e o foco em experimentos e empreendimentos pedagógicos. Sobre a forte presença de material produzido originalmente em inglês e os vínculos estabelecidos com grupos da Inglaterra, pode-se atribuir como determinante o canal aberto por Guéritte. Encontramos na própria revista uma justificativa sem assinatura, assim atribuída ao editorial, para tal traço: 
Algumas pessoas podem se surpreender com o lugar ocupado por livros ingleses e americanos em nosso boletim; primeiramente, nos é necessário dar a conhecer os livros estrangeiros que muitos de nossos membros não poderiam ler em texto original; além disso, para cada livro lançado em língua francesa sobre pedagogia ou psicologia infantil, dez são lançados em língua inglesa (NOTRE, 1924, p. 2)

Assim, a revista La Nouvelle Éducation, em alguma medida, retoma a via de influência inglesa no assunto antes protagonizado por Edmond Démolins. Isso se mostra tanto nas traduções, quanto na perspectiva de comparação dos discursos de Guéritte. A comparação se apresenta sempre como denúncia da precariedade da situação francesa em diversos aspectos sociais, com destaque para a educação e a música, diante da superioridade inglesa; perspectiva ora subjacente, ora bastante explícita.

Em nosso trabalho, a abertura aos materiais de língua inglesa assume dimensão fundamental com a influência de Satis Coleman ${ }^{65}$ na década de 1920 e as referências ao trabalho de Margaret James e às atividades e intercâmbios de grupos de flautas na década de 1930. Esses e outros conteúdos que caracterizam a área da educação musical na revista La Nouvelle Éducation serão objeto de exposição e considerações nas páginas que se seguem.

\subsubsection{A educação musical na revista La Nouvelle Éducation}

Assim como no trabalho exposto no capítulo anterior concernente à revista Progressive Education, a identificação de conteúdos ligados à área da educação musical se deu no processo de leitura, partindo da determinação de apenas algumas categorias prévias, como autoras e autores, temas, pessoas, grupos e instituições citadas e obras sugeridas.

A revista francesa tem estrutura que se mantém constante na maioria de seus números. É constituída por notícias e relatórios das atividades da associação; artigos sobre temas do universo da educação e da infância; uma seção que comunicava os

\footnotetext{
${ }^{65}$ Note-se que, além das referências à revista Progressive Education, cujos alguns artigos aparecem traduzidos para o francês em La Nouvelle Éducation, o primeiro livro de Satis Coleman, Creative Music for Children, foi publicado em 1922 tanto nos Estados Unidos quanto na Inglaterra.
} 
nomes dos associados mais recentes; textos sobre os círculos de estudo que aconteciam em diversas cidades, onde eram debatidos temas e oferecidas palestras para educadores, familiares de crianças e a sociedade em geral; uma seção de indicações bibliográficas; anúncios, sobretudo de pequenas escolas experimentais e cursos; e uma seção chamada Pensamento, onde figurava uma frase ou uma passagem não muito longa de caráter inspirador ou reflexivo, sem qualquer explicação ou desenvolvimento. Como exemplo desta última seção, reproduzimos uma citação que diz respeito ao foco de nosso trabalho, três versos de Paul Claudel: "Não basta olhar para enxergar/ Não basta, para ouvir, escutar/ É preciso criar para compreender" (PENSÉE, 1928, p. 15).

De acordo com o foco de nossa tese, interessa-nos sobremaneira os conteúdos que representam o desdobramento do ideário pedagógico renovador em assuntos que tocam o ensino de música. Assim, tomamos os artigos que tratam a área de maneira central ou secundária, bem como suas menções em todos os materiais veiculados pela revista.

\section{(a) Autoras e autores}

Nos materiais aos quais se pode atribuir autoria, foram identificadas 25 assinaturas diferentes. Madeleine Guéritte aparece como autora de destaque incontestável, com 11 textos assinados, enquanto outros 3 autores colaboram duas vezes para a revista e os demais assinam uma única vez. Acreditamos que a contribuição de Guéritte, no entanto, tenha sido ainda maior. Visto que Roger Cousinet não se ocupava de maneira considerável do tema da educação musical como Guéritte, os textos de responsabilidade do editorial que tocam nossa área parecem claramente de sua autoria ${ }^{66}$. Assim, o número de suas contribuições para a revista

\footnotetext{
${ }^{66}$ Também Gutierrez e Savoye (2018) atribuem grande parte dos textos não assinados na revista $L a$ Nouvelle Éducation à Madeleine Guéritte. Segundo os autores (Ibid.), o total de contribuições de Guéritte, considerando todas as áreas às quais ela se dedicava, como a difusão da abordagem montessoriana, a coeducação ou as responsabilidades de pais e mães, entre outras; e incluindo textos não assinados, mas que trazem marcas incontestáveis de sua visão e de sua escrita, ultrapassa a quantidade de cem artigos. Esse conjunto de escritos, bem como contribuições de Guéritte a outros periódicos, constitui fonte a ser explorada em futuras pesquisas afim de investigar o pensamento da autora, tradutora, musicista e militante. Quando assinados por iniciais, seus textos indicavam MTJG, em referência a Madame Tony Jules Guéritte, pois era costume à época que as mulheres usassem não apenas o sobrenome do marido, mas também seu primeiro nome.
} 
cresce para 18, em se tratando de textos sobre ensino de música ${ }^{67}$. Indicamos, abaixo, todas as autoras e os autores identificados mais de uma vez com os nomes como figuram nos documentos (Tab. 9). Aqueles que contribuíram apenas uma vez serão invocados ao passo que tratamos dos conteúdos da revista, caso suas contribuições mostrem-se pertinentes.

\begin{tabular}{|l|l|l|}
\hline Autor(a) & Número de contribuições & Detalhes \\
\hline Madeleine Guéritte & 18 & $\begin{array}{l}\text { Artigos sobre educação } \\
\text { musical, música e } \\
\text { sociedade, relatórios de } \\
\text { assembleias, relatórios de } \\
\text { eventos de música de } \\
\text { câmara, dentre outros } \\
\text { vários tipos de textos }\end{array}$ \\
\hline Maurice Chevais & 2 & Dois artigos \\
\hline Satis N. Coleman & 2 & $\begin{array}{l}\text { Um artigo e um resumo } \\
\text { de artigo }\end{array}$ \\
\hline Mlle. Mireille Godet & 2 & Dois artigos \\
\hline
\end{tabular}

Tabela 9 - Autoras e autores identificados em La Nouvelle Éducation

As contribuições de Mireille Godet ${ }^{68}$ não nos parecem relevantes para a presente tese, pois em seus textos ela apenas menciona a presença de atividades musicais, no entanto, não as discute nem apresenta práticas de inovação expressivas. Godet $(1925 ; 1926)$ trata, em ambos os artigos, das atividades desempenhadas no centro de brincadeiras de nome Infância Feliz - em francês, Centre de Jeux l'Enfance Heureuse - fundado em 1919 em Paris. ${ }^{69}$

\footnotetext{
${ }^{67}$ A contribuição de Guéritte aqui é tomada apenas como autora, mas sua importância como tradutora de textos originalmente em inglês é também notável.

${ }^{68}$ GODET, Mireille. “L’Enfance Heureuse”. La Nouvelle Éducation, nov. 1925, n. 39, p. 132 - 134. GODET, Mireille. “Au foyer de l'Enfance Heureuse”. La Nouvelle Éducation, abril 1926, n. 44, p. 55 56.

${ }^{69}$ Segundo as informações encontradas na revista, tratava-se de um espaço de atividades livres aberto às crianças às quintas-feiras. Em texto de Godet do ano de 1926, lemos que, neste dia da semana, as crianças não frequentavam a escola regular. A autora descreve o centro de brincadeiras, comunica a abertura recente de um segundo espaço na cidade e impele os associados a ajudarem na abertura de novos centros em todos os bairros de Paris.
} 
Maurice Chevais, assim como as demais autoras indicadas abaixo de Guéritte, contribui apenas duas vezes para a revista. Contudo, seus dois artigos são notáveis, assim como toda a contribuição do autor e educador para a área se consideramos o cenário de uma maneira geral, sem os limites desta revista específica. Chevais foi inspetor do ensino musical em Paris entre 1919 e 1940 e participava ativamente das revistas L'art à l'école e La musique à l'école. Intensamente envolvido em discussões sobre o ensino de música na escola regular francesa, Chevais era um defensor do canto escolar e crítico da ênfase no ensino de solfejo, buscando uma educação pelo canto que estivesse mais aliada ao desenvolvimento do gosto e da sensibilidade. Segundo Fijalkow (2004), Chevais é injustamente esquecido quando se fala dos educadores proponentes de métodos ativos no início do século XX. Seus traços de forte ligação com seu tempo aparecem, para além de proposições didáticas sobre o ensino de canto, com o grande interesse e a aproximação à área da psicologia experimental, sobretudo ao trabalho da Société Alfred Binet ${ }^{70}$ (CHAPUIS, 2004), e a defesa do valor pedagógico do uso de música gravada - ainda que o repertório associado não contasse de maneira significativa com as inovações que já circulavam nos meios composicionais (PISTONE, 2004).

Nos textos ${ }^{71}$ assinados por Chevais em La Nouvelle Éducation ficam evidentes sua defesa da educação pelo canto e sua recusa da iniciação pelo solfejo. O primeiro texto é constituído de passagens de um relatório elaborado por Chevais após sua participação no Congresso de Pedagogia Musical ocorrido em Berlim entre 24 de junho e 6 de julho de 1929. O artigo tem por título O ensino de música na Alemanha e é redigido em tom elogioso. As passagens selecionadas, segundo introdução do

\footnotetext{
${ }^{70}$ Alfred Binet foi o criador da revista L'année psychologique, em 1894, quando ocupava a diretoria do laboratório de psicologia da Sorbonne. Em 1902, foi convidado a dirigir a Société libre pour l'étude psychologique de l'enfant, à qual agregou um laboratório de pedagogia inserido em uma escola parisiense no ano de 1905. A associação passou a se chamar Société Alfred Binet depois de sua morte, em 1911. Claparède (in GUTIERREZ, 2011) o aponta como pioneiro na aproximação entre investigação em psicologia e instituição escolar na Europa. Gutierrez (2011) defende que o trabalho de Alfred Binet é de incontestável importância para a busca de Roger Cousinet, diretor de La Nouvelle Éducation, pelas bases científicas na educação. Em relação à influência da postura investigativa na área da educação musical, constam duas comunicações de testes elaborados e aplicados por Maurice Chevais na Société Alfred Binet. Em 1931, Chevais proferiu uma conferência dedicada a questionários sobre sensações e percepções ligadas à escuta musical e, em 1934, apresentou um teste de aptidão musical. Esse último foi desenvolvido entre 1928 e 1937 e tinha por objetivo ajudar professores, tencionando expor aptidões naturais e medir o desenvolvimento musical dos alunos (CHAPUIS, 2004).

${ }^{71}$ CHEVAIS, Maurice. "L'Enseignement Musical en Allemagne". La Nouvelle Éducation, abril 1930, n. 84, p. $53-58$.

CHEVAIS, Maurice. "Le travail Musical Libre". La Nouvelle Éducation, jul. 1932, n. 107, p.132 139.
} 
editorial, estão de acordo com os princípios que a revista vinha veiculando e a referência de Chevais à associação é direta quando ele comenta sobre as práticas de improvisação e composição. Além das atividades criativas, às quais nos dedicaremos em seção sobre esse tema específico, o artigo elogia o repertório de música tradicional popular, o solfejo relativo, indica a integração do canto com outras disciplinas na escola e defende uma educação musical que conecte o estudo técnico com a prática musical verdadeira em contraposição ao ensino do solfejo dissociado de repertório nas escolas francesas. Ele supõe que os professores berlinenses, ao saberem que na França se ensina solfejo sem canções, diriam que " [...] isso constitui um tipo de impasse, que os exercícios que não têm por finalidade o canto não têm razão de existir, e que a sua aridez os torna estéreis" (CHEVAIS, 1930, p. 56).

O segundo artigo de Chevais tem por título $O$ trabalho musical livre e é uma grande defesa das práticas de improvisação e composição. Ainda que restrito ao âmbito da música vocal e orientado para o ensino de escalas, a criação é defendida como via privilegiada para tal aprendizagem. Pelo seu conteúdo, esse texto também será objeto de nossa seção dedicada à criação.

Satis Coleman aparece na revista francesa como autora de dois textos ${ }^{72}$ publicados originalmente na revista Progressive Education. Ambos aparecem traduzidos para o francês e o segundo é resultado de um resumo feito pelos editores da revista. Quanto ao primeiro, de título A música criadora, trata-se de pequeno artigo resultante de conferência presidida por Coleman, à qual se seguiram comunicações de trabalhos em educação musical orientados por sua abordagem e dos quais tratamos no capítulo anterior ${ }^{73}$. É interessante notar que, mesmo que tenha sido o primeiro texto de Coleman na revista francesa, este não é necessariamente a apresentação do trabalho da educadora na publicação. Sete anos antes, em 1925, Guéritte já havia publicado um artigo de sua própria autoria sobre a Creative Music. Tratava-se de um

\footnotetext{
${ }^{72}$ COLEMAN, Satis N. "La Musique Créatrice". La Nouvelle Éducation, n. 101, jan. 1932, p. 13 - 15. COLEMAN, Satis N. "Fabriquons nos instruments de musique". La Nouvelle Éducation, n. 126, jun. 1934, p. $103-106$.

${ }^{73}$ Cf. p. 60 e 131 da presente tese. O artigo de Edith Potter, comunicação dessa conferência presidida por Coleman, viria a ser traduzido e publicado na revista francesa em sua edição de número 103, em março de 1932 (Cf. p. 177 da presente). Há ainda traduções de outros textos de publicações estadunidenses e inglesas que tratam direta ou indiretamente de nossa área, o que confirma que este momento é marcado pela circulação de ideias pedagógicas também em educação musical em meio aos movimentos de renovação escolar. Em sua maioria, estes textos não trazem indicação de tradutor, contudo, acreditamos que essa tarefa tenha sido amplamente desempenhada por Madeleine Guéritte por motivos já aqui expostos.
} 
resumo do livro Creative Music for Children $^{74}$, publicado em 1922, e apresentava em linhas gerais a proposta da professora da Lincoln School. Após essa apresentação feita por Guéritte em 1925, foram identificadas ainda menções ao trabalho de Coleman em oito números da revista até seu primeiro texto em 1932, sempre de maneira a apresentar a Creative Music como exemplo senão a ser seguido em detalhes, ao menos como inspiração para mudanças. Destacam-se como novidades a construção de instrumentos pelas próprias crianças e a diversificação destes, em oposição à iniciação musical centrada no ensino de piano.

O segundo texto de sua autoria a aparecer na revista é, na verdade, um resumo de artigo também oriundo da revista Progressive Education, intitulado Fabriquemos nossos instrumentos musicais. Como o título explicita, o texto apresenta o trabalho de construção de instrumentos pelas crianças, associando-o às práticas de improvisação e composição e à cooperação. Neste artigo, a construção de instrumentos também aparece como meio de evitar a iniciação musical na infância por instrumentos julgados inadequados porque muito complexos, e pela defesa da prática musical em oposição à escuta.

Observamos que a revista aqui focalizada foi uma das múltiplas vias assumidas por Maurice Chevais para se inserir no debate público sobre a educação musical escolar francesa à época. Além de assinar dois artigos, Chevais figurou como referência em textos de outros autores. Sua voz é um exemplar da ideia de que a educação musical pelo canto é a mais adequada à escola regular. Satis Coleman, sendo traduzida e referenciada diversas vezes por outros autores, representa, por sua vez, a defesa da prática instrumental para crianças pequenas, de acordo com os princípios da sua Creative Music. Ambos representam os desdobramentos do ideário dos movimentos de renovação escolar na área específica de música, mesmo que com diferenças fundamentais.

A identificação de autoras e autores que se dedicaram à educação musical nas páginas de La Nouvelle Éducation dá-nos a ver o inconteste protagonismo de Madeleine Guéritte no assunto. Sua escrita é polivalente e se presta à veiculação de ideias advindas de países estrangeiros, sobretudo em uma perspectiva de comparação; à documentação e veiculação das atividades musicais da associação; ao estímulo a novos empreendimentos e experimentos pedagógicos; e às suas próprias formulações

\footnotetext{
${ }^{74}$ Detalhes sobre essa obra foram apresentados no capítulo anterior.
} 
a respeito do ensino de música. Assim, a diretora da revista assume, entre suas várias frentes de militância, a defesa da educação musical no contexto da associação. Porque variados, os conteúdos de suas contribuições serão apresentados nas seções seguintes, de acordo com os temas identificados.

Os nomes dos demais autores e autoras, bem como suas instituições, cargos e outros traços de suas trajetórias, serão indicados nas demais seções da presente tese na medida em que essas informações se mostrarem relevantes. Na sequência, tratamos dos temas identificados na revista La Nouvelle Éducation quando esta foi veículo de ideias e práticas em educação musical.

\section{(b) Temas}

Os temas ${ }^{75}$ aqui apresentados foram identificados no decorrer do trabalho com as fontes. Por mais que tenhamos tomado as revistas com um objetivo definido - a observação da presença e do tratamento dado às práticas criativas quando em cenário renovador -, nenhuma das categorias constantes na tabela e nas considerações que se seguem foi determinada de maneira preliminar. Estes temas figuram nos artigos, nas notícias da associação, nos relatórios e anúncios de eventos e demais gêneros de textos.

Enumeramos aqui os temas de acordo com as assiduidade com que foram observados, em ordem decrescente (Tab. 10). Em seguida, tratamos dos temas mais significativos para a caracterização da educação musical no movimento pedagógico em questão. Confirmando nossa tese de que as práticas criativas já eram valorizadas nos movimentos de renovação escolar e constituíam um dos traços fundamentais da educação musical quando esta buscou coerência com o projeto pedagógico escolanovista, a criação é o terceiro tema de maior presença na revista.

\begin{tabular}{|l|l|l|}
\hline & Tema & Quantidade de ocorrências \\
\hline 1 & Repertório & 32 \\
\hline 2 & Construção de instrumentos & 29 \\
\hline
\end{tabular}

\footnotetext{
${ }^{75}$ Foram identificados 17 temas no total, dos quais apresentamos os 9 mais presentes. Assim, acreditamos ser possível observar os assuntos que animavam as discussões e as práticas em educação musical veiculadas pela revista, atestando a importância daqueles que estão no início da lista.
} 


\begin{tabular}{|l|l|l|}
\hline 3 & Criação & 27 \\
\hline 4 & Defesa do valor da educação musical & 22 \\
\hline 5 & Novas tecnologias & 21 \\
\hline 6 & Música como prática social para além da escola & 19 \\
\hline 7 & Cooperação & 17 \\
\hline 8 & $\begin{array}{l}\text { Música está presente, mas não são apresentados } \\
\text { detalhes }\end{array}$ & 16 \\
\hline 9 & Escuta musical & 15 \\
\hline
\end{tabular}

Tabela 10 - Temas identificados na revista La Nouvelle Éducation

Em um primeira observação da tabela acima, podemos ter uma visão geral dos temas de maior destaque na revista. A forte presença do repertório, da construção de instrumentos, da criação e das novas tecnologias nos dá a ver a proximidade com as caraterísticas da educação musical quando tematizada na revista Progressive Education, objeto de nosso capítulo anterior. A grande quantidade de textos que têm por objetivo, seja ele explícito ou tácito, a defesa do valor da educação musical, nos parece coerente com o caráter militante da publicação francesa. O fato de que os autores ocuparam-se da música em sua dimensão social, mesmo fora da instituição escolar, e de que essa tendência se mostra a partir da segunda década de veiculação da revista, reforça a ideia de que o movimento passou por mudanças no decorrer do período aqui focalizado. Nos dedicaremos a estes assuntos e à maneira como são tratados em La Nouvelle Éducation nas páginas que se seguem, tencionando alargar a compreensão das relações entre o cenário escolanovista e a educação musical. Iniciamos, dado nosso interesse específico na presente tese, pela criação musical.

\section{Criação musical}

Em consonância com o movimento estadunidense e confirmando nossa tese, a criação musical aparece como terceiro assunto mais frequente na revista La Nouvelle Éducation. Nesse material, a presença do tema se dá sobretudo em artigos que tomam a educação musical de maneira central ou secundária, bem como em relatos de eventos da associação ou prática pedagógica. Quando não tematizada diretamente por 
Chevais ou Coleman, a criação aparece frequentemente ligada ao trabalho destes educadores e na voz de Madeleine Guéritte. A influência de ambos mostra-se de maneira tanto expressa quanto tácita e desdobra-se nas ações de outras personagens abordadas nas próximas páginas, como Sigaux-Ravel e Margaret James. A existência de práticas pedagógicas que se apoiavam na abertura para a improvisação e para a composição de crianças mostra-se, sobretudo, nos relatórios de assembleias da associação; nas atividades de grupos como a Guilde des Faiseurs et Joueurs des Pipeaux, o Lycée des Jeunes Filles de Mâcon e o Collège de La Jonchère, os quais apresentaremos adiante e; em uma perspectiva de comparação, com a veiculação de experiências estrangeiras tomadas como exemplares.

As páginas seguintes trazem a exposição do material que trata do tema identificado na revista francesa e nossas considerações sobre estes. Tal exposição será organizada em três seções, a saber: (a) Chevais e Coleman: criação vocal e instrumental; (b) indícios de práticas criativas nas Assembleias de La Nouvelle Éducation e (c) Margaret James e os grupos de flautas artesanais.

\section{Chevais e Coleman: criação vocal e instrumental}

Os dois artigos de Maurice Chevais em La Nouvelle Éducation tratam do tema da criação musical. O primeiro, publicado em 1930, tem por título A educação musical na Alemanha e constitui-se de trechos de relatório feito pelo autor em congresso realizado em Berlim no ano de 1929. Como já exposto anteriormente, nesse texto Chevais assume um tom de admiração pelo trabalho com o qual teve contato no país vizinho, ao mesmo tempo em que critica o foco da educação musical francesa no ensino de solfejo.

Ao expor seu relatório, Chevais aborda o tema da criação tal qual ela era ensinada na Alemanha. O ensino é focado na prática vocal e, depois de apresentar a iniciação pelo desenvolvimento da percepção - através do estudo de intervalos ao invés de alturas fixas, partindo da tríade maior para chegar na escala -, Chevais (1930) afirma que os primeiros exercícios só provam o desenvolvimento da atenção e da memória e que "no entanto, nós queremos obter muito mais de seu [das crianças] sentido musical, despertar nelas as forças criadoras, lhes dotar de meios de expressão, levá-las a cantar e harmonizar como quiserem, a criar melódica e harmonicamente" (CHEVAIS, 1930, p. 55). 
$\mathrm{Na}$ sequência, então, ele expõe exercícios de harmonização, nos quais as crianças são convidadas a adicionar acompanhamentos a melodias conhecidas apenas "pelo sentimento de adequação, do que é natural, consoante, agradável, e sem a mínima teoria dos acordes" (CHEVAIS, 1930, p. 55). A criação melódica é conduzida por exercícios de criação de letra para melodias conhecidas, melodias para pequenos poemas, diálogos cantados e, por fim, canções inteiramente improvisadas e compostas pelas crianças, o que também pode evoluir para a adição de novas vozes.

Tais exercícios de criação estão, segundo Chevais, de acordo com o que $L a$ Nouvelle Éducation já vinha recomendando na França em matéria de educação musical. Como justificativa para tal abordagem, ele afirma que assim a criança se familiariza com a "língua dos sons" (CHEVAIS, 1930, p. 56), que a música vira expressão de seu pensamento e, em termos sobremaneira escolanovistas, que a música parte do interior para o exterior. Chevais refere-se ainda a outros aspectos da educação musical alemã, como a formação de professores, o repertório e os objetivos, entre outros, e que não abordaremos aqui, tendo em vista nosso foco na presente tese. A criação é apenas um dos vários temas desse artigo que toma o modelo estrangeiro como exemplo para repensar a realidade francesa e aparece, estruturado em exercícios e com pretensões de busca pelos "meios mais racionais" (CHEVAIS, 1930, p. 54), como via fundamental para a apropriação da linguagem tonal.

No segundo artigo, publicado no ano de 1932 e tendo por título $O$ trabalho musical livre, a criação tem lugar de maior destaque. É possível dizer que o artigo é uma grande defesa da improvisação e da composição como atividades essenciais da educação musical. Logo no início, o autor afirma que existem vários assuntos a serem debatidos sobre a música na escola, entretanto, ele escolhe se dedicar ao tema do "trabalho musical livre, em razão da atenção que lhe dirigem os amigos da $L a$ Nouvelle Éducation" (CHEVAIS, 1932, p. 132).

Sempre focado na música vocal, Chevais defende que a criação, sobretudo a improvisação, é conveniente às crianças, mesmo as menores, e que não deve amedrontar os professores. O procedimento é muito parecido com o que apresentou como proveniente da educação musical alemã: partir de poucas notas, mais especificamente do acorde maior, e operar por acumulação; sistema relativo no lugar de alturas fixas; diálogos cantados, etc. Para além de exercícios, uma estratégia de criação de canção apontada pelo autor nos parece digna de nota: fazer cantar a criança por uma razão que ele nomeia "útil”, porque em oposição aos exercícios, mas nos 
parece se tratar antes de atribuir um sentido ao ato. Ele dá como exemplo a sugestão de que uma criança cante para fazer sua boneca dormir, ou imitando lavadeiras, pastores ou outros trabalhadores que executam suas tarefas cantando. Ou, ainda, fazer cantar suas marionetes, assumindo um personagem. Assim, segundo Chevais (1932), a criança teria mais confiança para criar livremente.

Para o autor (1932), através de exercícios e situações de criação as crianças acrescentam novos conteúdos e tornam suas invenções mais complexas. Assim como já exposto no capítulo anterior quando tratamos das ideias de Satis Coleman, a notação musical se aprende no decorrer do desenvolvimento, sobretudo pela necessidade de registrar composições. Chevais evoca neste texto, além da imagem da música que se faz de dentro para fora, um outro termo próprio do cenário escolanovista, a saber: o aprender fazendo. Learning by doing na Progressive Education, o apprendre en faisant encontra na criação musical, segundo Chevais (1932, p. 138), a "aplicação mais direta" em nossa área. E reforça que a criação é o cerne de uma educação musical renovada:

Nós gostamos de dizer que a música deve ser um meio de expressão, que a criança deve recorrer ao canto para exteriorizar seus sentimentos, que nós devemos levá-la a se servir da língua musical, a falar música. Essas belas frases significam algo? A música é um meio de expressão? Para quem? Para aquele que compõe (CHEVAIS, 1932, p. 138)

Chevais (1932) fecha seu texto com uma ideia também defendida por Coleman e exposta no capítulo dedicado a ela: a ideia de que a composição musical é uma prática que compete a todos. Ele sublinha que não é questão de fazer da criança um futuro compositor profissional, e sim de garantir que todos tenham acesso a essa prática, não apenas aqueles previamente mais inclinados.

Segundo Pistone (2004), a inovação, quando comparada à modernidade propriamente musical dos círculos composicionais, só chega à escola francesa pela assunção das novas tecnologias, como o gramofone, os discos e a rádio. Os direcionamentos didáticos de Chevais apresentados em La Nouvelle Éducation, de fato, estão ainda circunscritos à música tonal. Contudo, apresentamos seus dois artigos pois, além de ser um dos únicos autores com mais de uma única contribuição na revista, nas duas ocasiões em que lhe foi dado espaço para comunicar suas 
concepções de educação musical, o educador acentuou a importância dos processos criativos.

A prioridade que Chevais $(1930 ; 1932)$ concede às atividades de improvisação e composição é observada nos seus textos, mas não apenas. Causaram-nos interesse suas ideias porque, além de seu protagonismo no cenário da educação musical francesa (FIJALKOW, 2004), Chevais aparece como referência expressa de SigauxRavel, educadora associada a práticas pedagógicas que incluíam composição musical nos relatos de eventos da associação. Nós nos ocuparemos das menções ao trabalho desta educadora adiante, entretanto, apontamos aqui que, no único texto de sua autoria publicado pela revista, a influência de Chevais é clara:

Para saber como iniciar as crianças na música e como fazer das aulas uma verdadeira recreação, aconselho às mamães e às professoras a leitura da excelente obra de Maurice Chevais: Avant le Sofège (éd. A. Leduc, Paris). É deste livro que vou falar hoje, bem como dos resultados obtidos graças a ele com minhas pequenas alunas dos liceus de moças de Lyon e de Mâcon (SIGAUXRAVEL, 1928, p. 24)

Assim, as proposições de Maurice Chevais estão na base do trabalho de uma das educadoras de maior destaque na revista quando se trata de educação musical e de estímulo composicional em notícias de prática pedagógica. $\mathrm{O}$ interesse por Chevais também se justifica, aqui, pela contraposição ${ }^{76}$ que a defesa de um programa de educação musical escolar que prioriza a prática vocal apresenta aos trabalhos de Coleman e Margaret James, bem como de todo o grupo de educadores que se engaja na prática de música de câmara e flauta artesanal na década de 1930.

Sobre o trabalho de Coleman, não nos ocuparemos aqui de apresentá-lo, visto que já foi objeto de nosso capítulo anterior. Interessa-nos, agora, verificar sua influência nos discursos e práticas da associação francesa. Como já apontado, seu primeiro texto traduzido para o francês na revista aparece no ano de 1932 e, sete anos mais cedo, seu primeiro livro já havia sido apresentado por Madeleine Guéritte. No entanto, acreditamos que os ecos de seu trabalho já estivessem presentes no primeiro texto que trata da área da educação musical em nossa periodização, no ano de 1924.

\footnotetext{
${ }^{76}$ Contraposição, esta, que não constitui apenas interpretação do cenário de nossa parte, mas realizouse em discussões como a que pode ser observada na voz de Lina Roth (1937), em texto intitulado Le pipeau et le chant publicado na revista La Musique à l'École e que abordaremos mais à frente.
} 
Este artigo $^{77}$, assinado por Madeleine Guéritte, é redigido em tom próprio à autora: inicia-se com a denúncia das insuficiências francesas do ensino de música tanto na escola regular quanto na escola normal, dedicada à formação de professores, para então “citar, mais uma vez, os Estados Unidos e a Inglaterra” (GUÉRITTE, 1924, p. 147) como exemplares. A autora faz referência apenas à revista londrina Panpipes, mas o único exemplo proveniente da Inglaterra é de um menino que construiu uma harpa em Winchester, ao que se segue o trecho:

Nas escolas novas americanas, encorajam-se vivamente as crianças a construírem instrumentos musicais e a comporem, elas mesmas, canções; em uma dessas escolas, os pequenos construíram uma flauta de pan para acompanhar uma dança de pastores de sua invenção e uma menininha fabricou uma cítara para tocar um canto de pastor de sua composição. Habituados a se expressar musicalmente com tanta facilidade quanto em desenho e a estudar os cantos e danças de outros povos, eles compuseram árias árabes para uma de suas comédias [...] (GUÉRITTE, 1924, p. 147)

Assim, no primeiro texto em que a educação musical é tematizada de maneira central em La Nouvelle Éducation ${ }^{78}$, já se observa a composição musical como prática exemplar. E ainda, o modelo apresentado - a composição atrelada à construção de instrumentos nos Estados Unidos - nos sugere que já se trata de circulação das produções de Satis Coleman.

A essa primeira aparição da criação musical na revista, seguem-se muitas outras de mesma natureza: associadas à construção de instrumentos e, tácita ou explicitamente, apoiadas no trabalho de Coleman. Pelo caráter prático e experimental da revista, o material constitui-se mais de relatos que indicam a presença do incentivo aos processos criativos, do que de produções que se debruçam de maneira central sobre o tema ou que lhe dispensam elaborações argumentativas. Considerando, ainda, o tom militante de Guéritte, a quem geralmente se atribui o material - sobretudo quando em uma perspectiva de comparação com países de língua inglesa e/ou fazendo referência ao trabalho de Maria Montessori -, e as mudanças já sinalizadas por outros autores que analisam esses movimentos em se tratando do fortalecimento da visão social da educação com a chegada da década de 1930, citamos aqui a última menção

\footnotetext{
${ }^{77}$ GUÉRITTE, Madeleine. "La Musique et les Enfants". La Nouvelle Éducation, dez. 1924, n. 30, p. $146-148$.

${ }^{78}$ Considerando nossa periodização que toma apenas as publicações de boletins independentes, iniciados em janeiro de 1924.
} 
ao trabalho de Coleman em nossa periodização antes de nos dedicarmos à próxima seção. Observamos que, tanto Coleman, servindo-se da imagem de homem primitivo que já discutimos anteriormente, quanto Guéritte, evocando músicos amadores de séculos anteriores, ensaiam certa resistência às formas de vida do mundo industrializado e às transformações dos hábitos musicais daí decorridas. Para tanto, ambas defendem a construção de instrumentos e a composição.

Aqueles que acompanharam nossa campanha durante os últimos onze anos em favor da nova educação musical engendrada pelas experiências de Mme Satis Coleman em Nova Iorque (conferir nossos artigos desde 1925) sabem porque essa educação, fundada na fabricação de instrumentos muito simples, é uma revolução tão profunda no domínio musical quanto a revolução de Mme Montessori no domínio da educação em geral. Ou ainda, é um retorno às leis naturais esquecidas há muito tempo, pois nos séculos $\mathrm{XV}$ e XVI, época do mais abundante florescimento musical, os amadores fabricavam seus instrumentos e compunham suas músicas. A música estava ao alcance de todos, como deve ser (GUÉRITTE, 1936, p. 11)

A alusão a modos de vida antigos e uma postura reticente em relação aos novos hábitos de consumo e produção de música são evidentes, assim como nessa citação, nos materiais relativos aos grupos de construção e performance de flautas artesanais. Esses grupos têm por nome Guilde, termo referente a organizações de artesãos da Idade Média, e serão objeto de nossa atenção mais adiante neste capítulo. Também as considerações sobre o Repertório, em sua valorização das canções tradicionais e a desconfiança da música que surge com a rádio, nos parecem uma face dessa resistência ao mundo urbano e industrializado que se impunha. A prática criativa musical e a construção de instrumentos se inserem nesse contexto, como oposição a uma realidade nova que, nos discursos de membros de La Nouvelle Éducation, aparece com ares de ameaça na medida em que é associada à alienação e à passividade nas atividades de trabalho e lazer.

\section{Indícios de práticas criativas nas Assembleias de La Nouvelle Éducation}

As notificações de práticas de criação musical, tanto em atividades de improvisação quanto de composição, figuram geralmente de maneira breve na revista La Nouvelle Éducation. Essas notificações não se constituem como um tema 
independente e elaborado, mas antes como indícios do que se passava em sala de aula e demais situações de ensino e aprendizagem.

Um gênero de material nos permite afirmar não apenas que as crianças tinham espaço para criar em aulas de música, mas também que esta atividade era valorizada socialmente: trata-se dos textos dedicados a relatar as Assembleias da associação. Esses eventos aconteciam uma vez por ano, geralmente no mês de março ou abril. As notificações da programação e das exposições, bem como a reprodução de artigos oriundos de comunicações e discussões das assembleias, eram veiculadas no boletim do mês de junho, podendo o relatório ser estendido à publicação seguinte.

A periodização aqui estabelecida - de 1924, ano de início da publicação independente, até 1939, ano de encerramento das atividades da associação, incluindo a produção da revista - cobre as notificações de 16 assembleias, da $3^{\mathrm{a}}$ a $18^{\mathrm{a}}$ (tab. 11). Dentre os relatórios dos 16 eventos, apenas no ano de 1931 não encontramos nenhuma menção à música nas atividades da programação ou nos materiais das exposições. Das 15 assembleias em que nossa área foi contemplada de alguma maneira, 9 contam com indicações evidentes de apresentações ou exposição de material de criação musical infantil, as quais destacamos na tabela a seguir.

\begin{tabular}{|c|c|c|}
\hline Ano & Boletim de ref. & Conteúdo musical no relatório \\
\hline 1924 & n. 26 , junho de 1924 & $\begin{array}{l}\text { Na exposição de materiais impressos, constam } \\
\text { "canções de crianças francesas e estrangeiras" } \\
\text { (NOTRE, 1924, p. 54). }\end{array}$ \\
\hline 1925 & n. 36 , junho de 1925 & $\begin{array}{l}\text { "[...] pela primeira vez pudemos expor melodias } \\
\text { compostas por crianças, provenientes de uma escola } \\
\text { de Sedan e das moças do Liceu de Mâcon, alunas de } \\
\text { nossa associada Mme. Sigaux" (NOTRE, 1925, p. } \\
62 \text { ). }\end{array}$ \\
\hline 1926 & n. 46 , junho de 1926 & $\begin{array}{l}\text { Exposição de uma coletânea de músicas para "fazer } \\
\text { dançar e cantar" (RAPPORT, 1926, p. 82) }\end{array}$ \\
\hline 1927 & n. 56, junho de 1927 & $\begin{array}{l}\mathrm{Na} \text { exposição, "[...] adoráveis canções compostas } \\
\text { por duas crianças ( } 8 \text { e } 6 \text { anos) da classe da Mme } \\
\text { Reinhart e uma dúzia de pequenos alunos ( } 5 \text { a } 12 \\
\text { anos) americanos de Satis Coleman" (RAPPORT, } \\
1927, \text { p. } 82 \text { ) }\end{array}$ \\
\hline 1928 & n. 66 , junho de 1928 & $\begin{array}{l}\text { Na exposição, "[...] canções compostas pelas alunas } \\
\text { de Mâcon de Mme. Sigaux-Ravel" (RAPPORT, }\end{array}$ \\
\hline
\end{tabular}




\begin{tabular}{|c|c|c|}
\hline & & 1928, p. 83) \\
\hline 1929 & n. 76, junho de 1929 & $\begin{array}{l}\text { Na exposição, livros de Satis Coleman e instrumentos } \\
\text { construídos por crianças. }\end{array}$ \\
\hline 1930 & n. 86 , junho de 1930 & $\begin{array}{l}\text { Em visita dos participantes à Infância Feliz (cf. p. } 159 \\
\text { da presente tese), um grupo toca instrumentos sob a } \\
\text { batuta de uma criança de } 7 \text { anos. O lugar é descrito } \\
\text { segundo orientação montessoriana. }\end{array}$ \\
\hline 1931 & n. 96, junho de 1931 & - \\
\hline 1932 & n. 106, junho de 1932 & $\begin{array}{l}\text { Apresentação de composições das crianças do curso } \\
\text { de mme Babelon-Brooke e mlle Talansier. } \\
\text { Apresentações musicais de grupos de escoteiros. }\end{array}$ \\
\hline 1933 & n. 116, junho de 1933 & $\begin{array}{l}\text { Na seção de música da exposição constavam flautas e } \\
\text { tubofone, obras de Satis Coleman e "charmosas } \\
\text { composições musicais livres dos alunos do curso } \\
\text { Educação e Rítmica" (RAPPORT, 1933, p. 82) }\end{array}$ \\
\hline 1934 & n. 126, junho de 1934 & $\begin{array}{l}\text { "[...] frescas composições musicais para flauta dos } \\
\text { alunos de Educação e Movimento e de uma } \\
\text { menininha de Mullhouse" (RAPPORT, 1934, p. 82). } \\
\text { Seção musical com materiais para construção de } \\
\text { flautas e repertório para este instrumento. }\end{array}$ \\
\hline 1935 & n. 136, junho de 1935 & $\begin{array}{l}\text { Na seção de música, flautas de bambu, fotos de } \\
\text { flautas antigas, repertório para flauta e de canções } \\
\text { populares e composições de crianças }\end{array}$ \\
\hline 1936 & n. 146 , junho de 1936 & Concerto de flautas \\
\hline 1937 & n. 156, junho de 1937 & $\begin{array}{l}\text { Na seção musical, flautas e "[...] charmosas } \\
\text { composições livres de crianças do colégio de La } \\
\text { Jonchère, que tiveram o mais vivo sucesso quando } \\
\text { seis delas as executaram em duos e trios" } \\
\text { (RAPPORT, 1937, p. 84). E ainda outras várias } \\
\text { apresentações musicais de crianças e adultos da } \\
\text { Guilde des Pipeaux, um grupo de cantores e } \\
\text { dançarinos da Bretanha para ilustrar uma conferência } \\
\text { sobre festas populares e um coro de moços dirigido } \\
\text { por E. Soubeyran. }\end{array}$ \\
\hline 1938 & n. 166 , junho de 1938 & $\begin{array}{l}\text { Exposição de flautas do colégio de La Jonchère, aula } \\
\text { aberta de flauta com grupo de crianças e um coro } \\
\text { criado na ocasião. }\end{array}$ \\
\hline 1939 & n. 176, junho de 1939 & $\begin{array}{l}\text { Noite musical, onde alunos do colégio de } L a \\
\text { Jonchère e da Joyeuse École de Boulogne tocaram } \\
\text { flautas. Consta que as crianças fizeram }\end{array}$ \\
\hline
\end{tabular}




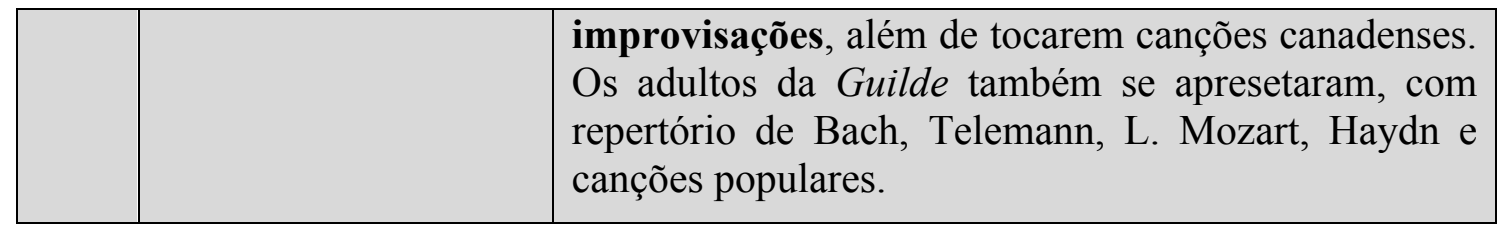

Tabela 11 - Indicações de criação musical infantil nos relatórios de assembleias da associação $L a$ Nouvelle Éducation (1924 - 1939)

A partir da tabela acima, podemos observar alguns aspectos da prática de criação musical na associação e de como essa tinha valor social, porque ocupando espaço no principal evento da associação. A assembleia sempre contava com exposição de materiais, especialmente os produzidos pelas próprias crianças, como livros, jornais e desenhos, aos quais são acrescentadas composições musicais em sua $4^{\text {a }}$ edição, aquela de 1925. Segundo Pratier (1927), contudo, já na assembleia de 1924 houve a apresentação de uma canção composta por uma criança de seis anos, composição essa proveniente dos Estados Unidos (fig. 10). No mesmo texto ${ }^{79}$, Pratier (1927) apresentava o liceu de moças de Mâcon como instituição onde a composição musical vinha sendo incentivada.

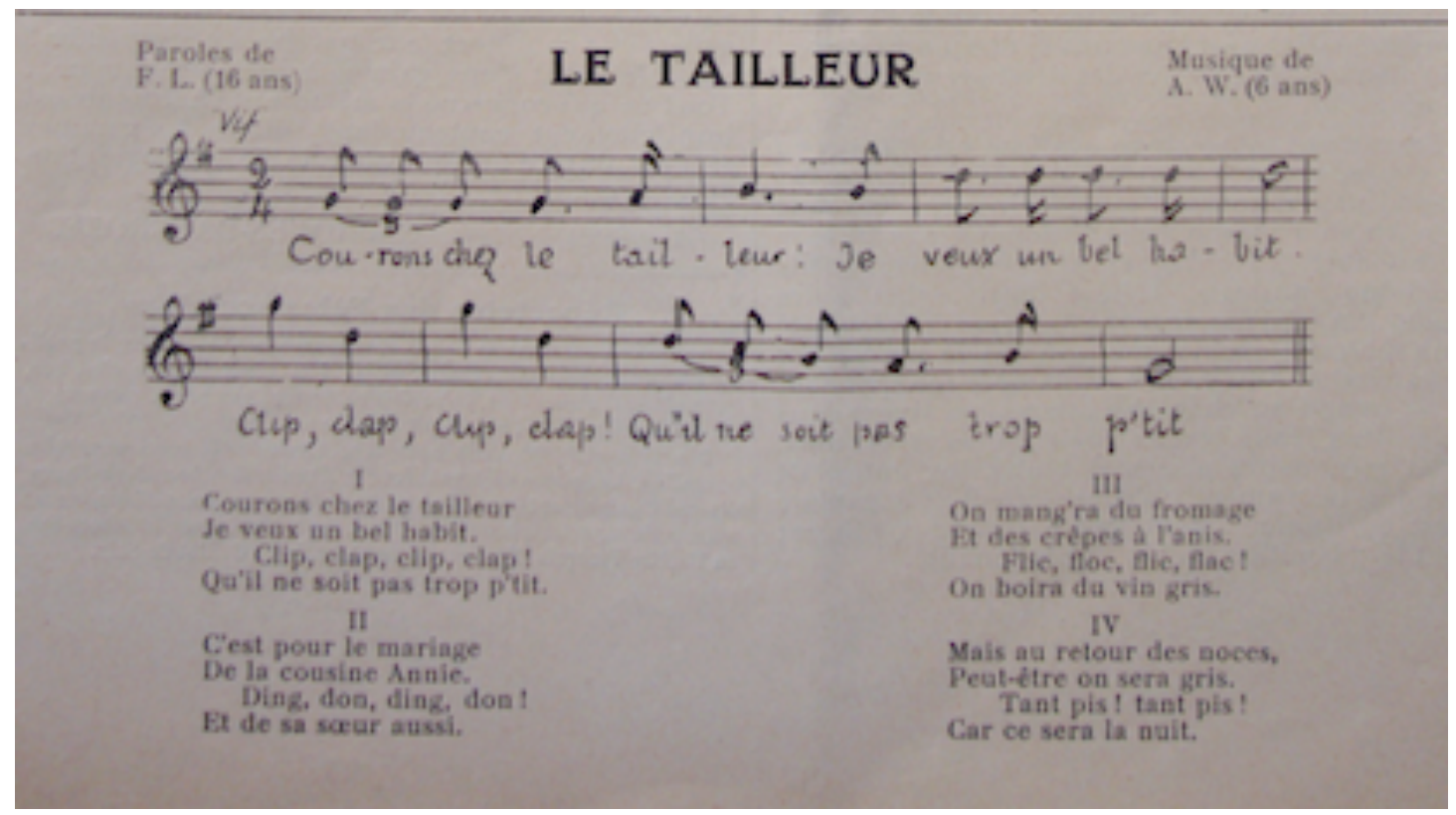

Figure 10 - Composição de criança dos Estados Unidos apresentada em Assembleia da associação La Nouvelle Éducation (PRATIER, 1927, p. 65)

\footnotetext{
${ }^{79}$ PRATIER, J. M. “L'enfant poète et musicien”. La Música à l'école, jan. 1927, n. 4, p. 64 - 65.
} 
O editorial de La Nouvelle Éducation apresenta como novidade as composições expostas em 1925, o que acreditamos se tratar de primeira ocorrência de criações de crianças francesas. Essas canções não são reproduzidas nem descritas na revista, no entanto, sabemos sua proveniência, como indicado na tabela. Não são fornecidas informações sobre a escola de Sedan e essa não é uma instituição que vem a ser recorrente nos materiais sobre música dos números seguintes, ao menos não tanto quanto o Liceu de Moças de Mâcon - o Lycée des Jeunes Filles de Mâcon - e sua professora de música, Mme Sigaux-Ravel.

Sobre a escola de Sedan, identificamos apenas mais uma indicação expressa de suas atividades com alguma referência à música, a qual acreditamos ser digna de nota pois é um dos traços na descrição de um cenário de uma classe experimental. Em texto $^{80}$ assinado por Guéritte publicado no início de 1926, ela narra um dia - 07 de novembro de 1925 - de observações na classe experimental de Sedan. A narradora retrata o ambiente como um espaço onde as meninas, que são 26 com idades entre 10 e 12 anos, trabalham em grupos. Guéritte descreve como elas se organizam com liberdade e comenta que, em um determinado momento, um dos grupos aborda a narradora e diz "Madame, você gostaria de nos ouvir cantar uma canção que acabamos de compor?” (GUÉRITTE, 1926, p. 6). A autora não dá detalhes da criação nem a descreve, apresentando apenas a composição como resultado de um ambiente de trabalho livremente organizado.

Em 1927 temos mais uma informação que parece ligada à escola de Sedan. Em artigo ${ }^{81}$ onde aborda o jogo dramático e a música na educação de crianças, Guéritte trata de nossa área assumindo claramente o trabalho de Satis Coleman como referência e toma a criação musical como algo que precisa ser fomentado na França. Ela afirma que os únicos ecos do trabalho de Coleman ouvidos até o momento eram aquelas canções expostas na Assembleia de 1925, em suas palavras: "As únicas tentativas foram essas melodias que expusemos em 1925, livremente compostas pelas crianças das classes de nossa associada Mme Sigaux-Ravel e de Mme Vivier-Bernard [...]” (GUÉRITTE, 1927, p. 78). Compreendemos, assim, que Vivier-Bernard seria a

\footnotetext{
${ }^{80}$ GUÉRITTE, Madeleine. "Notre classe expérimentale de Sedan". La Nouvelle Éducation, n. 41, jan. 1926, p. 6 - 7.

${ }^{81}$ GUÉRITTE, Madeleine. "Les jeux dramatiques et la Musique". La Nouvelle Éducation, n. 55, maio 1927, p. $76-78$.
} 
professora da escola de Sedan, no entanto, ela não volta a ser identificada nos anos seguintes da revista La Nouvelle Éducation ${ }^{82}$.

Mme Sigaux-Ravel ${ }^{83}$, por sua vez, e as instituições onde trabalhava, os Liceus femininos de Mâcon e de Lyon, aparecem ainda repetidas vezes em La Nouvelle Éducation. Na tabela acima, vemos que nas Assembleias de 1925 e de 1928 constam composições das moças da escola de Mâcon e que o editorial anuncia que em 1925 foi a primeira vez em que composições foram expostas. Contudo, se tomamos o material para além dos relatos de Assembleias, observamos que já no ano de 1924 havia referência à presença de composições das moças dessa instituição na revista $L a$ Musique à l'École em número de 1923, na seção de indicações bibliográficas Revistas e Livros da publicação que nos serve como fonte central.

Como já observado, Sigaux-Ravel faz referência a Maurice Chevais em seu único artigo assinado na revista. Além dessa referência, consta que Chevais figurava no repertório do coro de moças (NOUVELLES, 1926) e que, em uma de suas atividades como palestrante sobre educação musical nos círculos de estudos da associação, no ano de 1934 em Mâcon, Sigaux-Ravel apresentou os testes que resultaram da aproximação de Chevais à Société Alfred Binet. Sobre as criações das moças dos liceus, não encontramos descrições ou transcrições do material, no entanto, acreditamos ser possível ter alguma ideia de como procedia Sigaux-Ravel através de seu artigo Ensaio de iniciação musical ${ }^{84}$.

\footnotetext{
${ }^{82}$ A identificamos, entretanto, como autora de texto sobre a composição melódica na revista $L a$ Musique à l'École no ano de 1931, portanto seis anos depois da $4^{\mathrm{a}}$ Assembleia da associação. Neste artigo, publicado em três partes (nos números de março, maio e junho) e intitulado De la composition mélodique scolaire, a educadora apresenta a composição como atividade necessária na escola com vistas não à formação de compositores, mas ao desenvolvimento da compreensão musical, aqui entendida nos limites da música tonal. Suas indicações metodológicas se fundam em exercícios tanto de criação quanto de análise. Ela opera pela acumulação de conteúdos e, o que difere de outros educadores já expostos aqui, a leitura é condição primeira, pois as crianças partem da análise de frases para criarem as suas próprias, sem nenhum apelo ao desenvolvimento intuitivo, sendo a expressão invocada apenas depois de uma sequência exaustiva de exercícios executados pelas crianças. Não sabemos, contudo, se tal concepção didática ligada à composição já havia sido desenvolvida anos antes e se as canções expostas em 1925 haviam sido resultado de trabalho com essas características.

${ }^{83}$ Não encontramos, dentre o material selecionado para esta pesquisa, nenhuma referência ao primeiro nome da educadora, tampouco seu nome de família de nascimento. Visto que seu trabalho tem destaque, seria interessante, em pesquisas futuras, desenvolver uma investigação de caráter tanto biográfico quanto em relação aos trabalhos desenvolvidos nos dois liceus. Salientamos que, nas décadas aqui estudadas, a falta de menções aos primeiros nomes das mulheres e a assunção, por vezes, dos primeiros nomes de seus maridos, são marcas de uma sociedade ainda pouco afeita à igualdade de gênero.

${ }^{84}$ SIGAUX-RAVEL. "Essai d'initiation musicale". La Nouvelle Éducation, n. 62, fev. 1928, p. 24 28.
} 
A metodologia exposta pela educadora é, como a de Chevais, baseada na acumulação de intervalos, partindo da quinta para chegar à escala, sem alturas fixas nem leitura no início. O trabalho de Sigaux-Ravel tinha, segundo ela (1928), três eixos: a educação da escuta, a educação do gosto e a educação rítmica. Nos dois primeiros eixos vemos a influência de Chevais e, no terceiro, a introdução de princípios dalcrozianos.

A educação musical apresentada pela educadora pode ser vista com alguma ambiguidade, porque incentiva e valoriza as criações e prioriza a via da intuição para a aprendizagem de crianças pequenas e, ao mesmo tempo, assim como em Chevais (1930; 1932), está limitada ao sistema tonal e opera por acumulação. Exprime, assim, um pequeno avanço, o que vemos de uma maneira geral no cenário francês também nos grupos de flauta que abordaremos adiante e que centralizam as atividades musicais da Nouvelle Éducation na década de 1930, mas ainda sem rupturas estéticas e pedagógicas um pouco mais radicais como vimos no cenário estadunidense.

Apesar de não acessar essas composições, os discursos sobre elas nos indicam tais características não apenas pela orientação didática, mas também pelos adjetivos que acompanham as criações quando estas são notificadas. As criações infantis são apresentadas como frescas, charmosas, deliciosas; o que nos faz supor que não entravam em conflito com as ideias de música dos adultos que escreviam. Em um sentido político mais abrangente, podemos considerar que, ao mesmo tempo em que as propostas pedagógicas inovadoras dão às crianças um lugar ativo e a sociedade assume, progressivamente, a escolarização como um direito de todos, a criação aparece como via de exercer essa postura ativa em música e não mais como uma atividade apenas consagrada a especialistas.

Em todo caso, é preciso lembrar que as investidas vanguardistas europeias encontram refluxo mesmo nos meios composicionais depois da primeira guerra mundial, como observado por Pistone (2004) ao tratar do cenário parisiense:

Os eventos musicais de destaque nesta época [entre-guerras] poderiam, de fato, nos indicar os caminhos de um novo modernismo: escândalos criados pelos balés de Erik Satie (Parade, 1917; Relâche, 1924), concertos de bruiteurs futuristas italianos no Théâtre des Champs-Elysées (1921), Pierrot Lunaire de Schoenberg apresentado em Paris em 1921 e 1922, Dada (1926), Grupo dos Seis (1920), surrealismo (1924). No entanto, essa obra de Schoenberg, assim como o futurismo italiano, data, na verdade, de antes da guerra. Se os escândalos se multiplicam, eles sinalizam, de 
fato, mais uma vontade modernista do que a afirmação de uma verdadeira modernidade que muitos compositores viveram mais autenticamente antes de 1914. É suficiente comparar, em Ravel, os Três Poemas de Mallarmé (1913) e o Tombeau de Coperin (1917) ou, em Stravinsky, a Sagração da Primavera (1913) e as obras neoclássicas e neobarrocas posteriores (de Pulcinella ao Rake's Progress), ou constatar ainda que os balés suecos dos anos 1920 foram, em última análise, menos inovadores que os balés russos anteriores (PISTONE, 2004, p. 18)

Assim, o incentivo à composição musical no cenário pedagógico francês também não apresenta ares de vanguarda musical, com uma abertura para relações sonoras não totalmente circunscritas ao universo tonal, como vimos ter sido possível em meio à Progressive Education. Contudo, a criação tem espaço central na educação musical renovada e traduz, em nossa área, diferentes anseios do pensamento escolanovista. Como se pode observar na tabela 11, a criação aparece durante a primeira década de nossa periodização especialmente ligada ao ensino de canto, apesar das menções frequentes ao trabalho de Coleman e; na segunda década, observa-se também - e sobretudo - este tema ligado às atividades de grupos de flautas artesanais.

Além das menções que sinalizam a criação infantil circunscrita às atividades da associação, há também textos onde são expostas iniciativas estrangeiras. A abertura se dá principalmente às práticas provenientes dos Estados Unidos através da tradução de textos da revista Progressive Education. Além dos textos de Coleman, foram traduzidos outros três artigos ${ }^{85}$, dos quais apenas um não abordamos no capítulo anterior. Trata-se de texto de Allan Hulszier onde o tema não é central, contudo, a composição musical aparece como atividade importante em uma escola rural estadunidense e associada à aprendizagem da notação. Há ainda um relato ${ }^{86} \mathrm{de}$ Marion E. Scharr sobre um círculo de estudos da Child Study Association, em Chicago, onde foi apresentado o trabalho de David Dushkin, também abordado no capítulo anterior. A atuação deste educador vincula-se à proposta de Satis Coleman, o que é sublinhado na publicação francesa.

\footnotetext{
${ }^{85}$ SURETTE, Thomas W. "L’enseignement musical aux États-Unis". La Nouvelle Éducation n. 90, dez. 1930, p. 175. Texto publicado em francês de maneira parcial.

POTTER, Edith. 'L'Utilisation des instruments de musique dans les centres d'intérêts". La Nouvelle Éducation, n. 103, mar. 1932, p. $43-44$.

HULSZIER, Allan. “Une expérience d'éducation rurale”. La Nouvelle Éducation, n. 130, dez. 1934, p. 172 - 174. Este texto não trata da educação musical de maneira central, mas secundária.

${ }^{86}$ SCHARR, Marion E. "Une expérience d“éducation musicale”. La Nouvelle Éducation, n. 90, dez. 1930, p. $173-174$.
} 
As referências a Coleman nos assuntos da associação La Nouvelle Éducation compreendem, até o início dos anos 1930, alguns pedidos de envios de instrumentos construídos pelas crianças para a exposição nas Assembleias. Os pedidos são frustrados até o evento de 1933, onde constam modelos de flautas e tubofones pela primeira vez. A partir dessa Assembleia, como é possível observar na tabela 11, a prática de flauta torna-se uma tendência central da educação musical na associação. Existem também referências a cursos de orientação dalcroziana, ligando música e movimento, mas a construção de flautas e a prática de música de câmara com esse instrumento passam a ter destaque quase absoluto na revista, não apenas nos relatórios de Assembleias. A criação musical e vários outros temas que caracterizam nossa área, quase a totalidade daqueles listados na tabela 10, aparecem associados aos grupo de flautas a partir de então. Nesse contexto, outra educadora figura como exemplo ao lado de Satis Coleman: a inglesa Margaret James. Ganham destaque também as educadoras engajadas no grupo de flauta francês e as menções a grupos estrangeiros da mesma natureza, especialmente o inglês. Pela importância desse novo direcionamento observado na Assembleia de 1933, mas que já vinha permeando o material desde o ano anterior, lhe dedicaremos uma seção específica cujo conteúdo abrange também os estímulos criativos.

\section{Margaret James e os grupos de flautas artesanais}

Em meio aos frequentes apelos por uma educação musical orientada pela Creative Music e com a perspectiva de comparação, um texto não $\operatorname{assinado}^{87}$ portanto atribuído aos editores, muito provavelmente a Madeleine Guéritte apresenta o trabalho de Margaret James pela primeira vez em julho de 1932. De título Instrumentos de música feitos pelas crianças, o artigo conta que a educadora inglesa havia iniciado um trabalho de construção de instrumentos de sopros e cordas há seis anos, logo, em 1926. Nos moldes de Coleman, o projeto consistia em fazer as crianças - mas não apenas, agregando também adultos - fabricarem e tocarem os instrumentos em pequenas orquestras na Inglaterra. Essa divulgação apresenta os primeiros passos de James e também serve de propaganda para os cursos de férias para educadores oferecidos por ela. Encontra-se aí a primeira menção ao trabalho que viria a

${ }^{87}$ INSTRUMENTS de musique fait par les enfants. La Nouvelle Éducation, jul. 1932, n. 107, p. $140-$ 141. 
influenciar as ações em educação musical da associação La Nouvelle Éducation nos anos seguintes.

Alguns meses depois, em março de 1933, é publicado artigo ${ }^{88}$ de autoria de James traduzido para o francês. Neste artigo, original da revista The New Era, James apresenta suas atividades junto às crianças inglesas. São evidentes as ligações com o trabalho de Coleman, como a valorização da atividade manual, a imagem do homem primitivo como modelo de aproximação artesanal com o instrumento, a acumulação de notas, a notação numérica, etc. Nesse texto também há menções à atividade criativa, como a composição e a improvisação como práticas possíveis desde a manipulação das flautas mais simples. No mesmo número da revista encontramos a notícia da fundação, sob direção de James, da Pipers Guild, associação para a divulgação da prática da flauta de construção artesanal.

Ao texto de James traduzido para o francês acrescenta-se uma nota da redação da revista que, acreditamos, indica o início dos laços internacionais estabelecidos nos anos seguintes entre flautistas e educadores, principalmente na França e na Inglaterra. A nota comunica que no último congresso da LIEN - em Nice, 1932 - havia ocorrido uma demonstração de flauta por Charlotte Blensdorf MacJannet e, devido ao entusiasmo gerado, a educadora organizou um pequeno curso onde crianças e educadores, incluindo Guéritte, aprenderam a fabricar flautas (RAPPORT, 1933). Na nota ainda somos informados de que MacJannet faria uma conferência e uma demonstração de flauta na assembleia seguinte da associação francesa, o que acabou por não acontecer por motivos de saúde, sendo MacJannet substituída por Mme. Biedermann-Weber e sua cunhada, Mlle Mathilde Biedermann. Essas educadoras tinham atuação internacional e trabalhavam segundo os princípios da fabricação e prática de flauta tal qual elaborados por James a partir de Coleman, e também estavam intimamente ligadas à propagação da rítmica dalcroziana. Charlotte era filha de Otto Blensdorf, discípulo direto de Dalcroze e, junto à Mathilde Biedermann e outras educadoras, viria a desempenhar papel importante para a educação pela flauta na França.

Assim, além da procedência do trabalho Margaret James, a centralidade da flauta na associação La Nouvelle Éducation tem também ligações com educadoras engajadas no exercício da Rítmica. Como se observa na tabela 11, as composições

${ }^{88}$ JAMES, Margaret. "Nous fabriquons nos pipeaux". La Nouvelle Éducation, mar. 1933, n. 113, p. 41 $-44$. 
expostas na assembleia de 1932 e 1933 eram provenientes do curso de Educação e Ritmo, atribuído, em anúncios veiculados pela revista entre os anos de 1930 e 1933, a professores da Associação Francesa de Professores do Método Dalcroze (Fig. 11). A única educadora nomeada nestes anúncios era Mlle. E. Talansier - a quem se atribui o trabalho de composições com crianças apresentado na assembleia de 1932 ao lado de Mme. Babelon-Brooke (Tab. 11) - e não há, contudo, referências explícitas ao trabalho de construção ou performance em instrumentos além do piano, provavelmente usado como acompanhador para exercícios corporais.

\section{(ÉDUCATION et MRTHEMIE ) \\ Methode JAQUES-DALCROZE \\ Cours organisć par un groupe de professeurs \\ de l'Association Française des Professeurs de la Méthode Jaques-Dalcroze}

\section{Solfège \\ Rythmique \\ IMPROVISATION AU PIANO \\ Plastique}

Développement - par des expériences vivantes et individuelles - du sens rythmique, du sens musical et du sens plastique.

Cours dans différents quartieps de Paris

$6^{\circ}, 7^{\circ}, 8^{\circ}, 14^{\circ}, 16^{\circ}, 17^{\circ}$ arrond ${ }^{\mathrm{s}}$

3 Renseignements : Ecrire à Mille B. Talansiep

13 , rue Campagne première, $\mathrm{P}_{\mathrm{ARIS}}\left({ }_{14}{ }^{\mathrm{e}}\right)$

Figura 11 - Anúncio do curso Educação e Ritmo veiculado repetidas vezes na revista $L a$ Nouvelle Éducation entre os anos de 1930 e 1933

Em meio aos demais anúncios da revista observamos, porém, que Talansier atuou também em outro curso, o Educação e Movimento. Este ligava a Rítmica a diversas áreas, como a fabricação e a prática de flautas. 


\section{ÉDUCATION ET MOUVEMENT \\ FONDÊ TN 1926

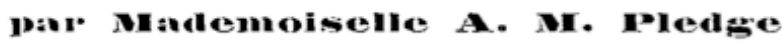 \\ Diplômée du Collège d'Education Physique de Chelsea, Londres}

cours de gymnastique, d'éducation rythmique, de danses populaires et de jeux

pour ENFANTs (à partír de 3 ans) et ADULTEs

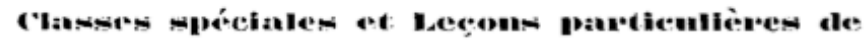

A) Gymuastigute corrective et médicale.

B) Développement d'oreiile et Solfége. Diveloppement musical et Piano. Gymnastique respiratoire.

Fabrication et jeu de Pipeaux.

L'enseignement donné dans les Cours a Education et Mouvement " s'appuie d'une part sur une tradition de principes de valeur reconnue, d'autre part sur les progrès acquis chaque jour en éducation par les travaux et les expériences d'éducateurs modernes.

92, Rue N.-D.-des-Champs $\left(6^{\circ}\right)$.

65 , Quai d'Orsay $\left(7^{\mathrm{e}}\right)$.

Collège Sévigné.

l'Ecole Pratique de Service Social.

L'Enfance Heureuse, Vaucresson.

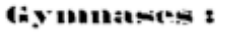

Jardin d'Enfants du Parc Montsouris. L'Ecole Nouvelle de Neuilly.

La Joyeuse Ecole, Boulogne-sur-Seine.

Direction grénérale : M Me A. M. PLEDGE.

Dirction, Musique if Rythmiqu' : M" ${ }^{\text {He }}$ E. TALANSIER.

Secrétariat : Mille S. TRELLIS.

Renst igntutututs : Ecrire à Mile $\mathbf{S}$ TRELLIS, 87, rue d'Assas, 6".

Figura 12 - Anúncio de curso Educação e Movimento veiculado na revista La Nouvelle

Éducation no ano de 1933

O curso de nome Educação e Movimento (Fig. 12) figura no relatório da assembleia de 1934 como fonte das composições infantis apresentadas (Tab. 11). Assim, parece-nos que os espaços de educação musical associada ao movimento e à Rítmica estiveram diretamente ligados à prática da flauta artesanal. Entretanto, a tendência ao uso desse instrumento encontrou logo força suficiente para que fossem criadas agremiações especialmente destinadas à sua difusão em alguns países. Em meio às publicações da revista aqui focalizada, destacam-se as menções à Pipers Guild, associação inglesa supracitada, e à Guilde des Faiseurs et Joueurs de Pipeaux, na França e estreitamente vinculada à associação La Nouvelle Éducation. Há ainda menções menos numerosas a grupos na Bélgica, na Dinamarca, na Suíça, na Irlanda e nos Estados Unidos. 
A criação da Guilde francesa foi notificada em número de outubro de $1933^{89}$. A partir de então, o grupo apareceu em 24 dos 59 números seguintes ${ }^{90}$, tornando-se assunto central da educação musical na revista. Lemos, na notícia de sua fundação ${ }^{91}$, os seguintes objetivos:

[...] fabricação de instrumentos simples (flautas de diversos tamanhos, viola, alaúde, etc.) com material simples (estoque de bambus e de facas da Guilde); aula instrumental mensal em grupo presidida por um professor diplomado da Guilde e oferecida aos membros ordinários; formação de professores que, para receber o diploma de ensino da Guilde, deverão seguir cursos, fazer estágios e comprovar conhecimentos musicais suficientes (GUILDE, 1933, p. 149)

Ao que se segue a lista de nomes do comitê da organização, sediada no décimo quarto bairro de Paris:

Mme. Charlotte Blensdorf-MacJannet, presidente.

Mlle. Biedermann, professora de música, diplomada da Pipers Guild, vicepresidente.

Mlle. E. Talansier, professora de Educação Rítmica e Musical, certificada pelo Instituto Jacques-Dalcroze, tesoureira.

Mme. T. J. Guéritte, secretária geral de La Nouvelle Éducation, membro do conselho.

Mme. A. S. Heu, professora de música, aluna de Marie Jaëll, membro do conselho.

M. Roger Cousinet, secretário geral de La Nouvelle Éducation, membro do conselho.

M. de Marande, membro do conselho.

Ambos os diretores de La Nouvelle Éducation compunham o quadro, daí a relação estreita entre as duas associações, bem como educadoras já anteriormente

\footnotetext{
${ }^{89}$ Existe ainda hoje um grupo francês promotor de atividades de construção de flautas e da prática de música de câmara com esses instrumentos. Este grupo, que se remete ao cenário que aqui estudamos como sua origem, intitula-se Guilde française des flûtes de bambou e pode ser conhecido em https://www.flutes-de-bambou.com/ Acesso em 21 mar. 2019.

${ }^{90}$ Edições de n. 120, 121, 126, 127, 129, 132, 133, 134, 139, 141, 145, 149, 154, 155, 156, 161, 162 , $163,165,166,168,170,175$ e 176.

${ }^{91}$ GUILDE française des Faiseurs et Joueurs de Pipeaux. La Nouvelle Éducation, out. 1933, n. 118, p. $149-150$.
} 
citadas. A fundação da Guilde se dá em razão da procura pelos cursos ofertados depois das primeiras demonstrações: no Congresso da LIEN em Nice - 1932, e na Assembleia da associação de 1933. Nos meses de maio e junho desse ano, aulas para adultos e crianças foram oferecidas por Mathilde Biedermann, sob direção de Charlotte Blensdorf-MacJannet, culminando na fundação da organização. O curso inicial foi dado em 25 de maio e contou com 30 alunos (AVIS, 1933), ao que se seguiu a propagação de eventos e cursos pelos círculos de estudo de cidades como Lyon, Mulhouse, Orléans, Lille, Nancy, Havre, entre outras, além das atividades centrais em Paris e em Saint-Cloud.

As atividades didáticas da Guilde pareciam assemelhar-se àquelas de Margaret James: construção dos instrumentos, sobretudo de sopro, e aprendizado da flauta pela acumulação progressiva de notas. De acordo com os relatos das Assembleias já abordados aqui, onde constam composições de crianças, a criação musical parece ter sido aspecto importante nesse ambiente de divulgação da flauta artesanal.

Às notificações das assembleias, adicionam-se ainda outras identificadas, como a ocorrência, na seção Nouvelles de maio de 1934, de relato da apresentação de composições infantis em flautas fabricadas e decoradas pelas crianças na festa daquele ano do curso Educação e Movimento (NOUVELLES, 1934). Outra ocorrência trata da composição musical livre como atividade exemplar tal qual desenvolvida no Collège de La Jonchère. Essa ocorrência figura em artigo onde Guéritte (1937) elenca atitudes a serem tomadas para a melhoria da vida musical francesa, dentre as quais consta o incentivo às práticas criativas. Em relato referente à reunião da Guilde em 13 de junho de 1937, consta que essa contou com a participação de 35 crianças de 8 a 15 anos, vindas de diversas instituições. Sobre a participação das crianças, lemos que "todos os pequenos executaram suas composições com perfeita naturalidade e grande alegria" (LES GUILDES, 1937, p. 145). No mesmo relatório da Guilde, consta evento onde 19 crianças do Collège de La Jonchère fizeram improvisações sob orientação de Mlle. Henriette Goldenbaum, professora de intensa participação na organização ${ }^{92}$.

\footnotetext{
${ }^{92}$ Seu nome é o de maior ocorrência entre as pessoas mencionadas nos materiais de La Nouvelle Éducation relativos à educação musical. Identificada em 23 edições, seu nome é mais referenciado que o de Satis Coleman, que aparece em 13 números, ou de Margaret James, que figura em 12 publicações. Essas referências tratam sempre de atividades desempenhadas pela educadora, como as apresentações do Collège de La Jonchère, no entanto, Goldenbaum não assina nenhum texto nem aparece como personagem de destaque em produções mais pormenorizadas. Pela forte ocorrência identificada na
} 
Salientamos que o incentivo à composição não se mostra apenas nesses indícios de atividades criativas com as crianças, mas também em um movimento pela produção de materiais para as novas formações. A novidade do modelo de organização e a especificidade do instrumento artesanal colocavam como necessidade a criação de repertório.

No ano de 1935 e no contexto do grupo inglês, por duas vezes - nas edições de março e novembro - lemos a incitação do compositor Vaughan William, presidente honorário da Pipers Guild, à produção de repertório. Citado em pronunciamento durante um evento da organização, ele encoraja os demais membros: “Arranjar árias antigas é certamente necessário, mas se vocês são capazes de fazer esse trabalho com tamanho talento, vocês também são capazes de compor; componham, então; precisamos de música nova para esses instrumentos novos" (CONCERTS, 1935, p. 45). Neste sentido, a produção original veiculada na revista é correntemente inglesa. Na seção Revistas e Livros dos anos 1930 constam não apenas livros de partituras, mas também gravações, e em todos esses gêneros de materiais há exemplos de produções de membros das Guildes.

Sobre a produção de material especificamente com caráter didático, é interessante observar que, mais uma vez, Madeleine Guéritte atua como tradutora ao publicar a obra de referência de Margaret James intitulada, em francês, Le Manuel des Faiseurs de Pipeaux. Essa tradução é anunciada no número de novembro de 1934 e disponibilizada para os membros na secretaria da associação. Assim como fez com Coleman, Guéritte abre uma via para que o material de língua inglesa possa ser difundido entre os leitores franceses.

A década de 1930 é marcada, assim, pela organização de grupos para a construção e prática de flautas. Esse cenário é palco de incentivos criativos não apenas às crianças, que compõem e improvisam suas melodias desde os primeiros furos talhados em bambu, mas também aos adultos membros da agremiação de flautistas e construtores, amadores e profissionais. O ambiente propicia, além das atividades criativas, a mobilização de outros aspectos da educação musical que têm ligação estreita com as ideias de renovação pedagógica correntes naquele momento, os quais serão abordados a seguir.

revista, acreditamos ser de interesse para a área que seu trabalho seja focalizado em investigações futuras. 


\title{
Repertório: o folclore e as novas tecnologias
}

Se voltarmos à tabela 10 , onde constam os temas referentes à educação musical identificados na revista, veremos que no início da lista está o Repertório. Esse tema aparece em diversos tipos de textos, como artigos originais, traduções, relatos de atividades da associação, notícias, etc, e expressa-se frequentemente através da oposição entre repertórios adequados e aqueles a serem evitados. Há menções a repertórios distintos, mas destaca-se sobretudo a valorização da música folclórica aqui geralmente referenciada como canção popular, a chanson populaire -, predominantemente francesa.

O repertório folclórico é evocado como portador de beleza, alegria, frescor, e outras qualidades compatíveis com o que se esperava para uma boa educação musical infantil, mesmo que não específico para crianças. Essas canções eram defendidas, aliás, como alternativa à música composta para ser cantada por crianças na escola e que, de acordo com membros da associação, não tinha a mesma qualidade. A passagem a seguir é exemplar dessa discussão sobre a qualidade das canções em contexto educativo.

\begin{abstract}
Nossos membros sabem o cuidado que temos ao indicar as melhores canções destinadas às crianças. Porém, não é suficiente indicar as boas canções, é preciso também lutar contra as más, que pululam, infelizmente! É preciso convencer os editores ignorantes que eles devem parar de publicar as piores baboseiras que se apresentam como canto escolar. E a única maneira de convencê-los é pela recusa, de nossa parte, a dar às crianças esses cantos cuja estupidez e mau gosto superam tudo o que se pode imaginar (GUÉRITTE, 1926, p. 157)
\end{abstract}

Guéritte dá um exemplo de letra de canção na sequência ${ }^{93}$, afirma que sua melodia é tão pobre quanto o texto e que, de uma maneira geral, o repertório produzido para fazer as crianças cantarem é em sua maioria de nível semelhantemente baixo. $\mathrm{O}$ ar de crítica é seguido pela indicação de uma antologia de cantos populares organizada pela Sociedade da Arte na Escola e com finalidade educativa.

A música tradicional é também evocada quando associada a um movimento mais amplo de valorização de práticas culturais tradicionais, como a dança, a

\footnotetext{
${ }^{93}$ GUÉRITTE, Madeleine. “Anthologie du chant scolaire”. La Nouvelle Éducation, n. 48, out. 1926, p. $157-158$
} 
escultura e o bordado em diferentes países. Esse cenário envolvia o interesse artístico - em meio às constantes comparações com a sociedade inglesa, encontramos referências ao trabalho de Cecil Sharp como exemplo de engajamento na busca por repertório em pesquisas de campo; também Vaughan William, já aqui citado pois engajado na Pipers Guild, desenvolveu trabalhos neste sentido -, mas não apenas. A valorização de tal repertório é mais uma marca de resistência às mudanças de hábitos referentes ao mundo do trabalho industrial e, em oposição a este, mecanizado, apresentava-se o mundo do trabalho artesanal como espaço de florescimento das faculdades criativas.

O interesse da associação neste sentido acaba por ultrapassar a escola e o folclore passa a ser visto em âmbito social mais abrangente, especialmente nos últimos anos da publicação. Destacamos como exemplar um artigo ${ }^{94}$ não assinado de título Artes Populares e Lazer de Trabalhadores, publicado em maio de 1937. Este texto trata de pesquisa de 1934, desenvolvida pelo Institut de Coopération Intellectuelle por pedido do Bureau International du Travail - instituições que, no entre guerras, precediam o que viria a se estabelecer em seções da atual Organização das Nações Unidas -, onde constavam informações de 24 países sobre o tema. O artigo apresenta um quadro da situação em alguns lugares, do qual destacamos um trecho referente à Inglaterra, onde existiriam iniciativas para a preservação destas práticas culturais em meio aos trabalhadores.

Todos são habituados a olhar a arte popular como um tesouro importante a ser preservado, e as classes abastadas são encorajadas a dar o exemplo. É preciso sempre pensar que, se não atentamos a isso, os trabalhadores modernos, totalmente mecanizados e despossuídos de qualquer relação de intimidade com seu trabalho, perdem as faculdades criativas, as quais camponeses e artesãos não perdem jamais (ARTS, 1937, p. 76)

No mesmo artigo, um pouco mais a frente e tratando de contexto internacional, lemos o seguinte trecho:

Em todos os lugares há esforços para mergulhar os trabalhadores nas tradições de artes populares e de ofícios rurais como meio mais seguro de lhes salvar da mecanização que lhes ameaça, de preservar suas faculdades criativas e de enriquecê-los por um conhecimento ativo das tradições de seu folclore (ARTS, 1937, p.78)

\footnotetext{
${ }^{94}$ ARTS populaires et Loisirs ouvriers. La Nouvelle Éducation, n. 155, maio 1937, p. 75 - 78.
} 
As práticas culturais tradicionais são apresentadas, então, como algo a ser ensinado aos trabalhadores neste contexto de mudança de hábitos de trabalho e de lazer. O artigo noticia a criação e o crescimento de Sociedades Musicais em diferentes países, coletivos que promoviam sobretudo a prática de música tradicional, além de associações ligadas à dança, à produção de vestimentas típicas, ao bordado, etc. É interessante observar que, por um lado, essa postura representa uma atitude de resistência a uma situação de precarização. São evocadas na revista, por vezes, as más condições de vida nas cidades que vinham crescendo com o êxodo rural e a elevação da taxa de desemprego. A educação do lazer servia a uma vida na qual, idealmente, haveria uma separação entre tempo de trabalho e tempo livre, mas também era mobilizada como ocupação para a quantidade crescente de desempregados. Por outro lado, esse repertório aparece sob uma camada de idealização que acaba por tomar a realidade social ao qual está ligado de maneira pouco complexa. Em um quadro simplista, aparece como antídoto à passividade própria à música veiculada pelo rádio na medida em que envolve os participantes na sua produção. Contudo, essa atividade apoia-se na manutenção de tradições e na tentativa de preservar modos de vida talvez já não mais coerentes com a realidade social contemporânea.

A negatividade com a qual são vistas as produções da crescente indústria cultural é evidente. Em nossa área, a desconfiança aparece direcionada às tecnologias de gravação e reprodução sonoras, ao novo repertório e aos novos hábitos aí originados. Não são poucas as passagens como a que citamos na sequência, retirada de um texto não assinado ${ }^{95}$ - de provável autoria de Madeleine Guéritte - sobre a educação para o lazer. Trata-se de uma sugestão de projeto em que seriam dadas ocupações a adolescentes como cuidar de uma casa ligada à escola e organizar atividades culturais. A justificativa para tal projeto se daria em oposição aos novos hábitos de consumo, como vemos no trecho:

No lugar de se deixar perverter o gosto e o espírito pelo luxo vulgar dos filmes, ornariam essa modesta casa e cuidariam de seu jardim; no lugar de se deixar estragar os ouvidos pelos piores refrães do gramofone e da rádio, descobririam a riqueza das obras primas e da música popular [música folclórica, tradicional]. Em suma, os alunos viveriam verdadeiramente a vida do espírito no lugar de virar pobres autômatos, sempre invejosos daquilo que não têm, sem

\footnotetext{
${ }^{95}$ L’UTILISATION des Loisirs. La Nouvelle Éducation, n. 153, mar. 1937, p. 33 - 34.
} 
terem podido criar seus recursos pessoais (L'UTILISATION, 1937, p. 34)

O repertório referenciado como "música da rádio e do gramofone" é muitas vezes invocado como maléfico para o desenvolvimento de crianças e adolescentes, assim como o cinema, também largamente combatido. No entanto, não há clareza sobre quais produções específicas seriam danosas, pois as menções são sempre vagas, em contraposição à música de concerto ou folclórica. $\mathrm{O}$ hábito de escuta de música gravada estaria, segundo os discursos veiculados na revista, na origem do desinteresse das crianças pelas aulas de música e da passividade frente à atividade musical. Acreditava-se que, através da popularização das novas tecnologias, a maioria das pessoas deixaria de tocar instrumentos e se contentaria com uma posição semelhante a de mero consumidor, comparando a música gravada a outros objetos de produção industrial.

Com o tempo, tal discurso negativo se mantém, mas também passa a coexistir uma opinião menos extremada. O controle sobre o repertório é apontado como a vantagem do gramofone sobre a rádio, porém admite-se que essa pode ser benéfica em alguns casos. Um exemplo é observado em mais uma comparação aos ingleses feita por Guéritte ${ }^{96}$. A rádio, segundo ela, pode expor tanto a grandes obras quanto aos piores horrores. Entretanto, mesmo com essas "condições perigosas" (GUÉRITTE, 1937, p. 70), existiam empreendimentos que enriqueciam o conteúdo radiofônico. Neste sentido, ela indica os trabalhos da União Radiofônica da Grã-Bretanha, que vinha, "desde a sua fundação, mantendo muito alto o nível da música ao se dedicar a uma verdadeira educação do grande público ao invés de incentivar seu mau gosto" (GUÉRITTE, 1937, p. 70).

Em relação ao gramofone, no mesmo texto Guéritte afirma que a França ainda não havia conseguido fazer um bom uso pedagógico do aparelho. Em outro texto ${ }^{97}$ este não assinado, mas provavelmente outra produção da autora - comenta-se sobre a necessidade impreterível de haver em cada escola um gramofone como meio de possibilitar às crianças o acesso à música. Há, contudo, a ressalva de que "a abundância de música gravada de má qualidade é tamanha que a seleção [de repertório] é difícil" (MUSIQUE, 1932, p. 29). O repertório sugerido é principalmente

\footnotetext{
${ }^{96}$ GUÉRITTE, Madeleine. "La grande pitié de la Musique en France". La Nouvelle Éducation, maio 1937 , n. 155 , p. $70-74$.

${ }^{97}$ MUSIQUE pour Enfants. La Nouvelle Éducation, n. 102, fev. 1932, p. 29 - 30.
} 
o de danças populares - com a ressalva de que não estão aí incluídas as danças de salão - e música para coro de diversos países. Além do repertório, também o uso do aparelho era passível de considerações e sugestões, como qual agulha seria mais indicada para as danças ou para a música vocal.

A respeito de outros repertórios, não observamos assuntos de tanto destaque quanto a defesa do folclore e a desconfiança da música veiculada pela rádio. A música de concerto é evocada em situações de sua valorização incontestada, sem atribuição de relevância a nenhum compositor em especial. Destacamos apenas que algumas menções são feitas a Gustav Holst, apresentado como grande compositor e valorizado em suas funções de educador em uma escola de moças em Londres - a Saint Paul Girls School - e junto a trabalhadores em centros sociais, entre outras atividades de ensino. Sua filha, Imogen Holst, aparece diversas vezes na revista devido ao seu engajamento na Pipers Guild e como compositora de repertório para o movimento de flautas artesanais. Dentre os relatos de atividades do grupo de flautas francês, observamos que o repertório baseia-se em árias antigas, música barroca, música folclórica, composições das crianças e repertório produzido pelos adultos especialmente para o novo instrumento.

\section{A construção de instrumentos: Coleman, James e a perspectiva da} comparação

Ainda tratando dos temas identificados e expostos na tabela 10, observamos que a construção de instrumentos é um dos assuntos mais recorrentes na revista quando esta se ocupou da educação musical. Tamanho destaque explica-se, para nós, pela valorização do trabalho manual no contexto escolanovista, pela resistência aos novos modos de consumo, e sobretudo pela influência de Satis Coleman e Margaret James através das traduções de Madeleine Guéritte. Na primeira década da publicação, as referências concentram-se na educadora estadunidense e, ao passo que James desenvolve trabalhos inspirados em Coleman focalizando os instrumentos de sopro, sua voz também passa a ecoar nos textos da associação francesa.

A construção artesanal de flautas e a performance coletiva com esses instrumentos despontam, em alguma medida, como dissonância em um ambiente onde a música vocal predominava como meio de educação musical. Assim como o trabalho de Coleman nos Estados Unidos, esse movimento pelas flautas artesanais 
colocava como possibilidade a prática instrumental para crianças pequenas, as quais, até então, eram iniciadas na música predominantemente através do canto coral, quando em situação de ensino coletivo, ou pelas aulas individuais de piano. Coleman, James e Guéritte, além das demais educadoras e educadores aí envolvidos, defendiam que as crianças pequenas poderiam tocar instrumentos em grupo na escola, além de cantar, o que não era tomado como evidente naquele momento.

Um exemplo de tal conflito é observado na revista La Musique à l'École, em sua edição de janeiro de 1937. As flautas artesanais eram assunto frequente nessa revista na década de 1930, tanto em relatos de experiências educativas com estes instrumentos quanto em discussões sobre a técnica de construção, afinação, métodos, etc. Dentre os artigos dedicados ao instrumento, destacamos que na edição supracitada consta um texto de título As flautas artesanais e o canto, assinado por Lina Roth $^{98}$. Já no início do artigo a educadora se coloca em diálogo com Maurice Chevais, citando-o e propondo uma resposta ao educador que havia afirmado, em publicação recente, que a prática instrumental não deveria tomar o lugar da prática vocal na educação e que o uso de instrumentos só seria benéfico em situações onde falta ao professor meios de trabalhar a percepção dos alunos ou quando se constitui como suplemento ao ensino do canto. Ao que Roth (1937) responde de maneira a conciliar os benefícios das duas atividades e de acordo com suas experiências pessoais, visto que era professora de flauta na cidade de Saint-Menoux (Fig. 13). Ela aponta os seguintes aspectos como positivos: em lugares onde os professores não tinham uma formação satisfatória, o instrumento ajudaria na afinação e no solfejo; a flauta, por ser um instrumento de fácil aprendizagem, motivaria as crianças em iniciação musical; as crianças poderiam reproduzir em casa o que faziam na escola, tendo um instrumento de referência, além de também fazerem uso mais livre do instrumento fora de aula, como quando tiravam melodias de ouvido, prática espontânea muito corrente entre suas alunas; etc. Assim, a prática da flauta é apresentada pela educadora não apenas como um fim em si mesma, mas como prática que vinha a enriquecer as habilidades musicais também presentes na música vocal, ao invés de concorrer com ou ameaçar o canto coral no ambiente escolar.

\footnotetext{
${ }^{98}$ ROTH, Lina. "Le Pipeau et le Chant”. La Musique à l'École. n. 194, jan. 1937, p. 61 - 62.
} 


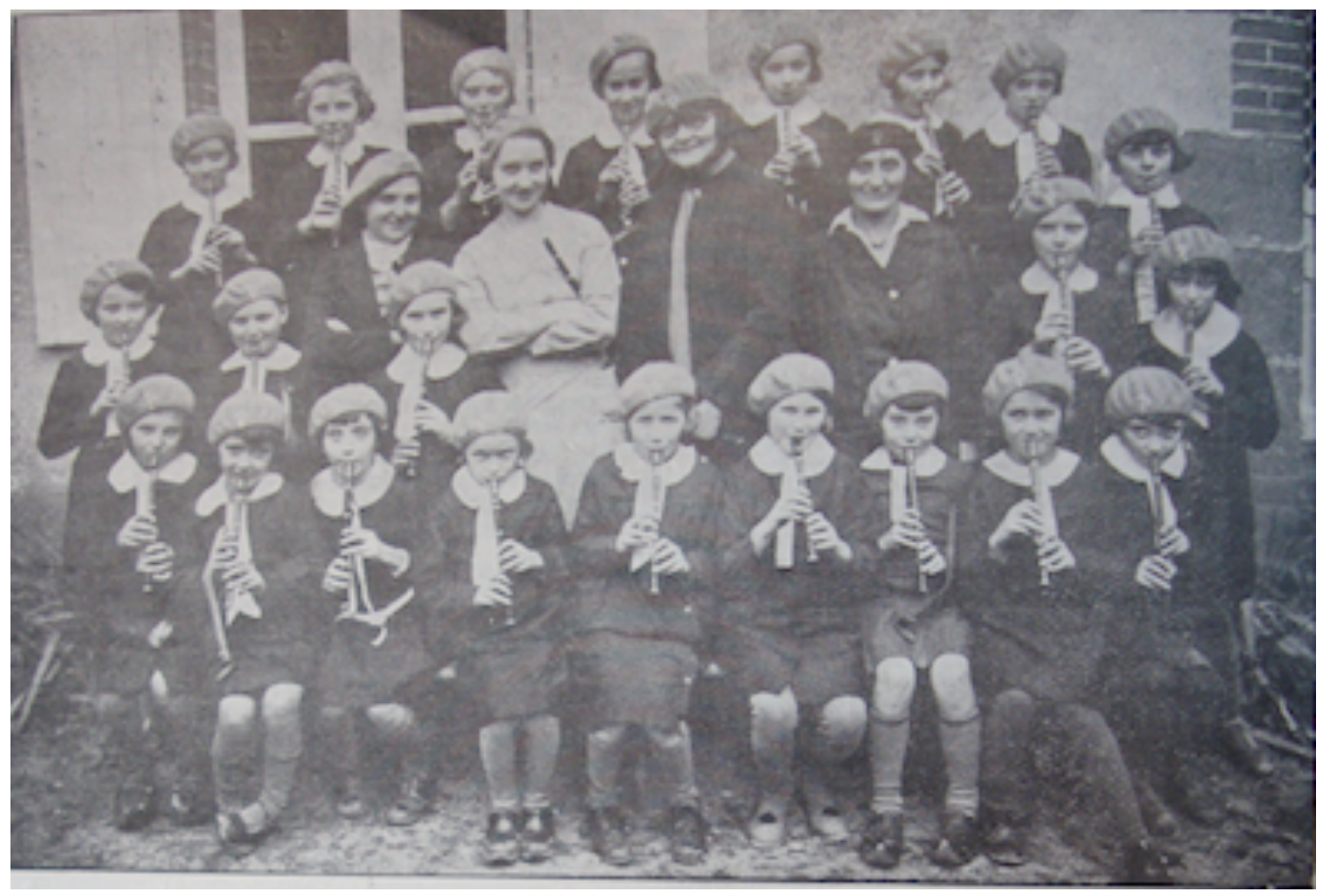

Figura 13 - Foto publicada em La Musique à l'École intitulada As primeiras flautas na escola: Saint-Menoux, Mlle Lina Roth e suas alunas (LA MUSIQUE À L'ÉCOLE, 1935)

Em La Nouvelle Éducation, como já exposto, o movimento das Guildes de construção de flautas é fortemente presente pois ambas as organizações contavam com membros em comum. A Guilde e a defesa da prática instrumental na educação musical escolar surgem de maneira coerente com vários aspectos do contexto escolanovista, como a circulação internacional de ideias - aqui evidenciada com a via de contato entre produções de língua inglesa e francesa na figura de Madeleine Guéritte e na profusão de Guildes em diversos países -, a valorização do trabalho manual, a organização cooperativa, etc. A ênfase na música de câmara ${ }^{99}$, explicitada por vezes, e a mobilização não apenas de crianças nestas organizações, mas da sociedade de uma maneira geral, a partir do apelo ao engajamento de amadores, nos parece também indicar coerência com uma tendência mais abrangente do movimento na mudança da década de 1920 para a década de 1930.

Como observado por alguns autores e já exposto na presente tese, é possível afirmar que ocorreu um deslocamento da atenção à criança como indivíduo,

\footnotetext{
${ }^{99}$ Uma passagem exemplar da importância atribuída à música de câmara consta em relatório das atividades do Círculo de Estudos de Savoie publicado na revista, a saber: "Nós lamentamos apenas que se tenha feito algumas crianças tocarem soli, o que é exatamente contrário aos nossos princípios: $1^{\circ}$ porque nossa educação musical tem por objetivo o renascimento da música em conjunto, em oposição à música de virtuoses; $2^{\circ}$ porque fazer as crianças tocarem soli na frente de uma plateia adulta as incentiva a afetação contra a qual lutamos" (NOS, 1937, p. 62)
} 
predominante nos primeiros anos, para uma visão mais ampla da educação como prática social. Segundo Haenggeli-Jenni e Hofstetter (2011), isso se mostra principalmente na politização evidente do congresso da LIEN em Nice, no ano de 1932, nos conflitos existentes mas não assumidos até então e na diminuição do protagonismo de Adolphe Ferrière. Para Jenkins (2000), um dos sinais desse deslocamento é a mudança do título da revista publicada pela LIEN em língua inglesa, de início The New Era e, nos anos 1930, The New Era in Home and School, acompanhada por mudanças no conteúdo da publicação.

A organização de grupos para a prática da música de câmara que ultrapassava os limites da sala de aula - sem entretanto se desconectar desta, pois as flautas artesanais eram defendidas e praticadas também em contexto escolar -, parece-nos um desdobramento de tal tendência em nossa área específica. $\mathrm{O}$ anúncio da seção da Guilde em Paris (Fig. 14) veiculado na revista deixa clara a ideia de que essa seria uma oportunidade para fazer música em família. Pensando no contexto de recrudescimento nacionalista na política europeia da década de 1930, a organização em rede destes grupos de flautas estava conectado com o caráter internacional escolanovista. Um exemplo desse aspecto é visto em relatório das atividades de diversas Guildes em publicação de março de 1938, onde noticia-se que um grupo de moças inglesas fez uma turnê por várias cidades alemãs e, ao fim, afirma-se que "em todos os lugares foi lida a mensagem de Margaret James, dizendo que as Guildes des Faiseurs et Joueurs de Pipeaux trabalham pela arte, pela cooperação e pela paz" (LES GUILDES, 1938, p. 44).

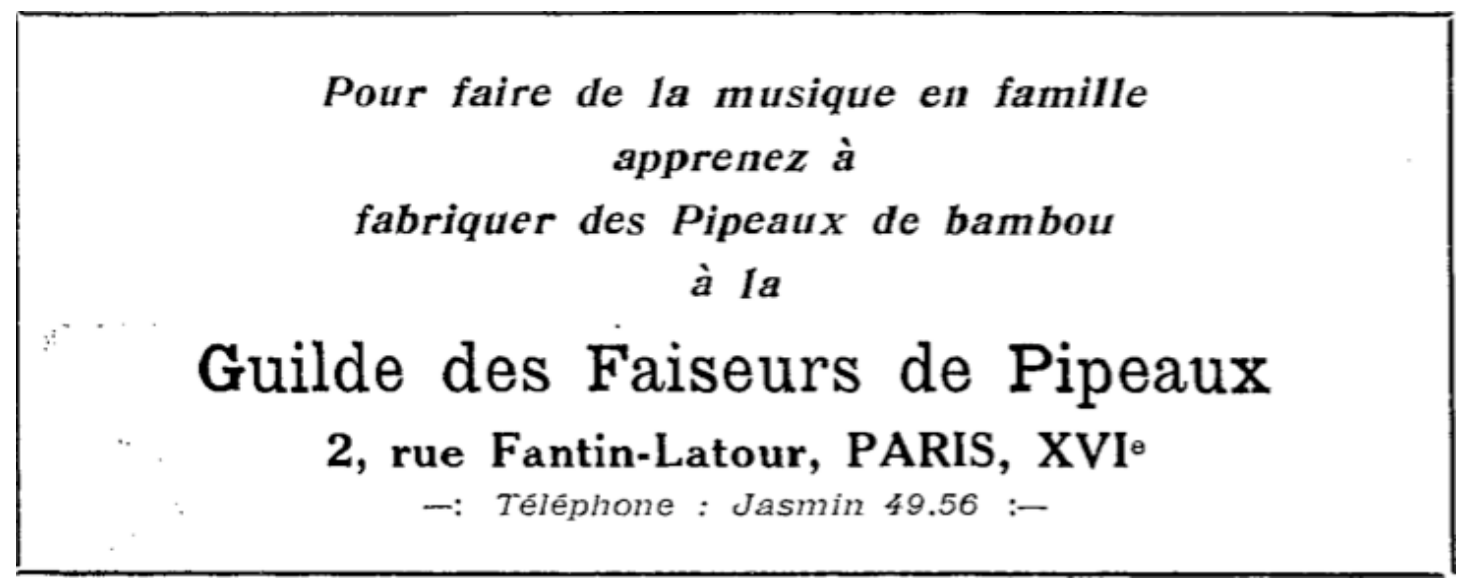

Figura 14 - Anúncio da seção de Paris do grupo de construção de flautas artesanais (LA NOUVELLE ÉDUCATION, 1938, n. 163, p. V) 
Como último exemplo da perspectiva comparativa que permeia a revista $\mathrm{e}$ desta inclinação social desenvolvida com o passar dos anos, apontamos duas produções tardias de Madeleine Guéritte. Em maio de 1938, penúltimo ano de funcionamento da associação e de publicação da revista, ela escreve um texto ${ }^{100}$ dedicado ao assunto da prática musical amadora. Esse artigo trata de uma revista inglesa chamada $O$ músico amador - The amateur musician -, fortemente recomendada pela autora, e apresenta uma grande quantidade de associações privadas inglesas que promoviam atividades musicais não profissionais. Constam orquestras e coros de empresas, grupos rurais, bibliotecas musicais, sociedades de apreciação, etc. Guéritte (1938) convoca a sociedade francesa, sobretudo membros da elite, a se engajar em iniciativas similares na França de maneira independente, sem esperar pela ação do Estado. De sua parte, ela se dedica, em nome da associação La Nouvelle Éducation, a recolher dados referentes a ações de mesma natureza que já vinham sendo desenvolvidas em território francês e ainda outras informações sobre a vida musical, de maneira a estabelecer um quadro da situação tal qual ela se apresentava no interior do país. Para tanto, publica uma lista de questões (Fig. 15). e pede que os membros lhe mandem pareceres de diferentes regiões. Tal lista compreende as seguintes perguntas: 1) Quais são os recursos musicais de sua cidade e proximidades? 2) Se existem corais e orquestras, quais obras eles apresentam? 3) Os músicos pertencem a meios diversos? 4) Suas escolas de ensino fundamental e médio têm uma orquestra? Quais obras são estudadas nestas instituições? 5) Se têm um coral, quais obras são estudadas? 6) Alguns programas de concertos poderiam ser enviados para nós? 7) Qual música coletiva é feita em sua região? Pelos adultos? E pelas crianças? 8) Rádio e gramofone incomodam a vizinhança ou funcionam de uma maneira conveniente e discreta? 9) Vocês têm música militar, tão preciosa para as orquestras?

${ }^{100}$ GUÉRITTE, Madeleine. "La Musique d'amateurs". La Nouvelle Éducation, maio 1938, n. 165, p. $73-78$. 


\section{ENQU苗TE}

Vous pouvez nous aider dans notre tentative d'éducation musicale en nous donnant les renseignements suivants :

1. Quelles sont les ressources musicales de votre ville ou de votre bourg ? Et aux environs ?

2. S'il existe chorales ou orchestres, quelles œuvres donnent-ils ?

3. Les musiciens appartiennent-ils à des milieux divers ?

4. Votre lycée ou vos écoles ont-ils un orchestre ? Quelles œuvres $\mathrm{y}$ étudie-t-on ?

5. Si c'est une chorale, quelles œuvres y étudie-t-on ?

6. Peut-on nous envoyer quelques programmes de concerts ?

7. Quelle musique d'ensemble fait-on dans votre entourage ? Les grandes personnes ? Et les enfants ?

8. Radio et gramophones gênent-ils les voisins ou fonctionnent-ils d'une façon convenable et discrète ?

9. Avez-vous une musique militaire, si précieuse pour les orchestres?

Figura 15 - Enquete publicada com vistas a recolher informações sobre a vida musical no interior da França (LA NOUVELLE ÉDUCATION, 1938, p. IV)

Em março e abril do ano seguinte, 1939, são veiculadas algumas das respostas recebidas. De maneira descontente, Guéritte (1939) lamenta não ser larga a contribuição, porém aprova a qualidade do conteúdo. Algumas iniciativas são expostas, como pequenas formações, projetos de concertos escolares, novos aderentes ao movimento de flautas artesanais, etc. A partir das respostas e comentários enviados pelos membros, Guéritte (1939) elabora algumas conclusões, onde se reafirmam a ênfase na prática de música de câmara, a atitude de reserva em relação à música gravada e a incitação às organizações sociais como bibliotecas musicais para o empréstimo de partituras.

A exposição das respostas à enquete deveria continuar nos meses seguintes, no entanto, as atividades de publicação e da associação de uma maneira geral são interrompidas no verão de 1939. Essas últimas contribuições de Guéritte à área da educação musical são exemplares de sua militância. Quase sempre pela via da comparação, sobretudo em relação à sociedade inglesa, Guéritte fez de La Nouvelle Éducation um veículo de propagação de iniciativas estrangeiras no intuito de modernizar o ensino e encorajar a prática musical na escola francesa e para além dela. Ao examinarem as diversas frentes de atuação desta autora, como a coeducação e a 
educação de pais e mães, Gutierrez e Savoye (2018) consideram que, para além da formulação escolanovista que clamava pela criança no centro da escola, o ativismo de Guéritte seria melhor compreendido como uma defesa da criança no centro da sociedade. Ao que acrescentamos que essa consciência coletiva não se limitava aos aspectos ligados à infância, mas também abarcava, principalmente nos últimos anos, a prática musical.

O estudo dos materiais franceses, principalmente das publicações da associação La Nouvelle Éducation, nos dão a ver aspectos importantes de como a educação musical se desenvolveu no cenário escolanovista deste país. Ora inovadora, como nas iniciativas pedagógicas de construção de instrumentos e de incentivo às práticas criativas através de ações em sala de aula e com a exposição dos trabalhos feitos pelas crianças; ora reticente em relação às novas tecnologias e às mudanças de hábitos da vida urbana; a área se mostra, nesses materiais, imersa nos conflitos de seu tempo. É também digno de nota que este material, ainda mais que as publicações estadunidenses, reflete o caráter internacional dos movimentos de renovação escolar, pois mesmo que seja publicado por uma associação centrada na realidade francesa, refere-se constantemente a iniciativas estrangeiras.

$\mathrm{Na}$ sequência, nos dedicamos a investigação de como o ideário escolanovista se mostra em publicações brasileiras. Tendo como fonte principal a Revista Brasileira de Estudos Pedagógicos, observamos as características de seu conteúdo dedicado à música de maneira a compreender tanto suas especificidades quanto sua coerência com o cenário internacional. 


\section{Capítulo 4 - Educação musical e renovação escolar no Brasil}

\subsection{O escolanovismo e a Revista Brasileira de Estudos Pedagógicos}

Como já abordamos no primeiro capítulo da presente tese, um dos traços fundamentais do ideário escolanovista é a sua circulação internacional no início do século XX. Mesmo que de caráter heterogêneo, o quadro de renovação pedagógica constitui-se como uma rede de conexões entre diferentes países, cada qual engendrando propostas de educação e respondendo às especificidades locais da escolarização da infầncia à sua maneira.

A inserção do Brasil no espaço internacional de circulação de ideias pedagógicas nos é descrito por Lourenço Filho na passagem a seguir. O autor defende que a década de 1920 é expressiva, visto que pouco se havia produzido sobre informações dos sistemas educacionais estrangeiros nos anos anteriores.

Esse isolamento de ideias dos educadores brasileiros com relação ao que se passava no estrangeiro é rompido em 1926, quando Fernando de Azevedo, realizando em São Paulo um inquérito entre vários educadores, leva-os a referir-se às tendências renovadoras do ensino no estrangeiro ${ }^{101}$. Um dos participantes desse inquérito, logo após, publica uma obra sobre o movimento da escola nova, com referência ao que então se praticava em numerosos países (Lourenço Filho, 1963 [1 $1^{\text {a }}$ ed. em 1929]). Em 1928, de regresso de um curso nos Estados Unidos, Anísio Spínola Teixeira edita Aspectos americanos de educação, e Gustavo Lessa (1929), no ano seguinte, uma apreciação sobre a escola ativa no mesmo país. Isaías Alves (1934), de volta de estudos que também realizou nos Estados Unidos, dá igualmente a conhecer as suas observações (LOURENÇO FILHO, 2004, p. 31)

Assim como na rede que se formava entre os países, também em território brasileiro as ideias em torno da escolarização se propagavam com algumas nuances. Segundo Vidal (2004), os discursos de educadores do estado de São Paulo traziam marcas do pensamento escolanovista através do ensino intuitivo já na década de 1910 . Porém, de acordo com a autora (Idem), é com o deslocamento do eixo da política

\footnotetext{
101 "As respostas ao inquérito promovido por Fernando de Azevedo, publicadas no diário O Estado de S. Paulo, foram depois reunidas em A educação pública em São Paulo (1947)" (LOURENÇO FILHO, 2004, p. 31).
} 
educacional no decorrer dos anos 1920 para a sede do governo republicano, o Rio de Janeiro, que a gramática propriamente escolanovista se impõe. As reformas da instrução pública são acompanhadas da incorporação de termos como método de projetos e centros de interesse, dando novos contornos semânticos ao campo pedagógico. $\mathrm{Na}$ esteira da construção dessa representação da escola brasileira em termos escolanovistas, funda-se o Ministério da Educação e Saúde em 1930, cujo quadro contará com Lourenço Filho por mais de 40 anos, ocupando diversos cargos técnicos (VIDAL, 2004).

Os anos que se seguem são palco da consolidação da educação como tema de interesse nacional. A publicação do Manifesto dos Pioneiros da Educação Nova em 1932, seguida da idealização do Instituto Nacional de Estudos e Pesquisas Educacionais - INEP - em 1936 e de sua fundação em 1938, são marcas da atividade de intelectuais a favor da educação pública de tendência escolanovista, tanto no âmbito da opinião pública quanto em instâncias oficiais. A fundação da Revista Brasileira de Estudos Pedagógicos em 1944 pode ser compreendida como parte deste cenário político.

O INEP, em sua origem, tinha a divulgação pedagógica entre uma de suas funções, ao lado de documentação, pesquisa e execução de políticas públicas. A criação da revista se dá sob responsabilidade do Instituto, à época dirigido por Lourenço Filho, a quem se atribui o editorial do primeiro volume (ROTHEN, 2005). Um retrato dos propósitos da publicação nos é fornecido neste editorial, cujo trecho a seguir exemplifica sucintamente os anseios de consolidação do tema no debate público e a modernização do pensamento pedagógico:

[...] se apresenta esta publicação, animada do sincero desejo de contribuir para a formação de uma esclarecida mentalidade pública em matéria educacional; para dar reflexo às ideias do professorado brasileiro de todos os níveis e ramos do ensino; para registrar, enfim, os rumos da pedagogia brasileira na fase, em que se encontra, de viva renovação e de clara afirmação social (EDITORIAL, 1944, p. 6)

Ainda sobre o primeiro volume, Rothen (2005) aponta que em sua Apresentação, assinada pelo então Ministro da Educação Gustavo Capanema, e no Editorial, atribuído a Lourenço Filho, evidenciam-se os seguintes traços que guiam a linha editorial na ocasião da criação da RBEP: "o ponto de vista nacional, assume a 
postura escolanovista e trata de temas práticos" (ROTHEN, 2005, p. 195). Segundo Saviani (apud ROTHEN, 2005), o direcionamento escolanovista é predominante na revista até, pelo menos, 1962.

Destaca-se que, apesar de se apresentar como via para o debate público, a revista passa a aceitar submissão de artigos apenas no ano de 1983. Até então, os artigos são todos solicitados, o que, segundo Rothen (2005, p. 219), "evidencia a proposta de seus editores exercerem a liderança moral e intelectual em relação à educação". Sendo assim, a RBEP nos pode fornecer um retrato das ideias pedagógicas brasileiras que figuravam entre aqueles intelectuais que tiveram força política para garantir espaço na publicação.

Inserida no "mercado planetário de ideias" (MONARCHA, 2009, p. 57), sua estrutura contou desde os primeiros volumes com a seção Informações do estrangeiro, onde constam textos sobre os sistemas de educação de diversos países, e é apontada pelo próprio Lourenço Filho (2004) como uma das publicações responsáveis pela divulgação numerosa de estudos de Educação Comparada no Brasil. É possível observar a forte presença de produções estrangeiras também em sua seção de indicações bibliográficas, sobretudo estadunidenses.

Se comparada às demais revistas aqui tomadas para análise, a RBEP tem publicação tardia. Nossa periodização concernente à Progressive Education vai de 1925 a 1944; no caso de La Nouvelle Éducation, nossa seleção abrange os números publicados entre 1924 e 1939. A publicação da RBEP se inicia apenas em 1944 como periódico do Instituto Nacional de Estudos e Pesquisas Educacionais - INEP; e se mantém até os dias atuais. Decerto, em 75 anos de atividades a revista passou por mudanças significativas, bem como as instituições às quais esteve ligada. As descontinuidades de tendências dessa publicação e algumas de suas análises e tentativas de periodização são abordadas por Rothen (2005). O autor defende que, até a década de 1980, as histórias da RBEP e do INEP se confundem, envolvendo de maneira central, em suas duas primeiras décadas, intelectuais responsáveis pela difusão do pensamento escolanovista no Brasil, como Lourenço Filho e Antônio Teixeira. De maneira a observar se existiram ecos das publicações estrangeiras que constituem nosso estudo na RBEP, selecionamos seus números desde seu lançamento até o ano de 1950.

O caráter oficial da revista também é um ponto de diferenciação em relação àquelas estrangeiras. Tanto a Progressive Education quanto La Nouvelle Éducation 
foram produzidas por associações compostas principalmente por educadores em atividade na escola de educação básica e intelectuais ligados a centros de formação de professores. A RBEP, por mais que tenha nascido como uma publicação comprometida com assuntos da educação pública, sobretudo em nível básico, era uma via ligada a instituições oficiais e sua produção estava pouco próxima dos educadores com atuação cotidiana em sala de aula. Essa especificidade acaba por se desdobrar em conteúdos também oficiais, como na frequente difusão de textos legislativos, algo não observado nas demais revistas.

Assim como nos capítulos precedentes, tomamos aqui uma revista como fonte central - mas não unívoca - para examinar a difusão do ideário escolanovista no Brasil. De acordo com os conteúdos aí identificados, amplia-se o leque de referências com vistas a alargar a compreensão do contexto, como feito nas demais seções da tese.

\subsubsection{A educação musical na Revista Brasileira de Estudos Pedagógicos}

A escolha pela RBEP em nossa pesquisa justifica-se pela coerência com o quadro internacional observado através da imprensa pedagógica, já evocado nos capítulos anteriores. No contexto brasileiro, sua escolha diz respeito à tendência escolanovista característica da publicação. Em nosso esforço específico de examinar a educação musical em contexto escolar, a revista pareceu-nos profícua para alargar a compreensão das convergências entre nossa área e o pensamento da Escola Nova.

A presença da educação musical na RBEP, se comparada às revistas analisadas anteriormente, é escassa. A baixa identificação do tema em meio à publicação brasileira pode ser compreendida pelas diferenças de periodização. A quantidade de conteúdos identificados é condizente com a quantidade de anos cobertos pela seleção: da revista estadunidense, 19 anos; da revista francesa, 15 anos; da RBEP, apenas 7 anos. O lançamento tardio é um dos motivos e também nosso corte não se estende para além de 1950 com o intuito de não afastar temporalmente a publicação nacional daquelas estrangeiras. Assim, uma das particularidades de nosso estudo do contexto brasileiro é o fato de ser mais sucinto que aqueles expostos nos capítulos precedentes, particularidade esta condizente com as fontes. 
A educação musical quando identificada na revista espelhou algumas de suas propriedades gerais, como o caráter oficial e a influência de produções estadunidenses. Sua leitura foi guiada da mesma maneira das demais, a partir da identificação de conteúdos em textos que priorizavam a área ou a abordavam de maneira periférica. Tratamos, a seguir, de tais conteúdos.

\section{(a) Autores e autoras}

Antes de listar os autores e autoras identificados em nosso estudo, faz-se necessário atentar para um fato: nenhum texto foi produzido com a finalidade de ser publicado pela RBEP. Trata-se de um conjunto composto por textos oficiais, replicados a partir da difusão original em Diário Oficial e uma ata de conferência; artigos traduzidos do inglês, notadamente de publicações de origem estadunidense; e dois artigos de autores brasileiros reproduzidos de jornais de ampla circulação. Nenhum autor assina mais de um texto no período aqui focalizado.

\begin{tabular}{|l|l|}
\hline Autoria & Ocorrências \\
\hline Legislação & 8 \\
\hline $\begin{array}{l}\text { Ata da I Conferência de ministros e } \\
\text { diretores de educação das repúblicas } \\
\text { americanas }\end{array}$ & 1 \\
\hline Vanett Lawler & 1 \\
\hline William S. Elsbree & 1 \\
\hline Winifred E. Bain & 1 \\
\hline Antônio Bento & 1 \\
\hline João Caldeira Filho & 1 \\
\hline
\end{tabular}

Tabela 12 - Autoria de textos onde consta o tema da educação musical na RBEP

Os textos oficiais, como leis e portarias dedicadas especificamente ao Canto Orfeônico, à música ou ao Ensino Primário e Normal, e a Ata da I Conferência de 
Ministros e Diretores de Educação das Repúblicas Americanas, são documentos que escapam à ideia de autoria como condição explícita. Esses discursos têm atribuição difusa, não personificada, porque provém de grupos grandes e institucionais. Não nos ocuparemos da pormenorização da autoria de textos dessa natureza, entretanto, atentamos para o fato de tal gênero de texto não ter sido encontrado nas demais revistas e de ter presença destacada nesta. Acreditamos tratar-se de especificidade condizente a uma publicação de cunho oficial, ligada a um ministério, enquanto as demais revistas eram produzidas por associações livres de educadores. Além de tais textos não serem facilmente atribuídos a autores determinados, não nos deteremos sobre eles por distanciarem-se, sobretudo os legislativos, dos documentos analisados até aqui. Uma análise correta de tais materiais demandaria um estudo específico e não seria coerente com os capítulos anteriores da presente tese.

Dentre os textos traduzidos do inglês, apenas um tem o tema da educação musical como foco, aquele assinado por Vanett Lawler e intitulado "A educação musical em 14 repúblicas americanas". O texto é exemplar do trabalho da autora, que se dedicou à educação musical em uma perspectiva internacional. Neste artigo, Lawler trata de viagem que realizou durante seis meses observando projetos de educação musical em alguns países, dentre os quais: México, Guatemala, El Salvador, Honduras, República Dominicana, Haiti, Cuba e Porto Rico (LAWLER, 1946). Esta viagem tinha como objetivo preparar um relatório sobre a área nos países supracitados, em uma cooperação entre a Confederação Nacional de Educadores Musicais (EUA) e a divisão de Música da União Panamericana. Lawler trabalhou em diversos projetos que visavam o estudo e o incentivo à educação musical em contexto internacional, como o Conselho Internacional de Música - International Music Council (IMC) - da Unesco. Em 1953, fez parte da comissão de organização e apresentou uma palestra na Primeira Conferência Internacional de Educação Musical, evento onde foi fundada a Sociedade Internacional para a Educação Musical International Society for Music Education (ISME).

Os outros dois textos traduzidos do inglês, assinados por William S. Elsbree referenciado no artigo como integrante da Columbia University - e Winifred E. Bain - referenciada no artigo como integrante do Wheelock College - tratam da educação nos Estados Unidos. O primeiro tem como foco a educação primária, enquanto o segundo aborda as escolas maternais e os jardins de infância. Ambos foram traduzidos 
de folhetos publicados pelo Conselho Americano de Educação e chegam ao tema da educação musical de maneira indireta e pouco detalhada.

Os artigos de autores brasileiros eram especialmente dedicados à educação musical e escritos por críticos de arte: Antônio Bento, colunista do Diário Carioca, e João Caldeira Filho, colunista do jornal O Estado de São Paulo. Ambos apareceram na revista em sua seção Através de Revistas e Jornais, dedicada à reprodução de textos sobre educação originalmente difundidos em outros veículos impressos.

O texto de Bento (1946), intitulado Música e Educação, tinha por objetivo comentar uma portaria sobre ensino de Canto Orfeônico, especialmente as finalidades trazidas pelo documento oficial. Essas finalidades, expostas por Bento (1946), eram principalmente ligadas ao caráter coletivo da prática musical, ao incentivo à sociabilidade calcada nas ideias de civismo e disciplina. O colunista discorre sobre a disposição que a música traria para o sentimento de solidariedade entre os seres humanos citando como exemplo o uso da música pelas religiões como fator fundamental. Apesar de apresentar uma pequena ressalva ao fato de que os alemães haviam, poucos anos antes, desempenhado um papel bélico altamente destrutivo na política mundial, mesmo, segundo ele, sendo muito musicalizados e possuindo "a melhor música do mundo" (BENTO, 1946, p. 361), sua escrita é demasiadamente positiva. O ideal de comunhão social através do civismo e da disciplina, característicos da ditadura do Estado Novo, lhe aparece como benéfico.

O artigo de Caldeira Filho (1945), por sua vez, aborda tema muito diferente e interessa-nos sobremaneira. É neste artigo, de título "Educação musical infantil”, que a área é tratada de maneira específica pela primeira vez na RBEP. Confirmando nossa tese de que existiram ideias em educação musical especialmente ligadas ao pensamento escolanovista e de que estas circularam internacionalmente na primeira metade do século $X X$, em coerência com o movimento de uma maneira geral, este texto tem como um dos objetivos a promoção do trabalho de Satis Coleman. Além de apresentar a proposta da estadunidense como o que de melhor se fazia à época em matéria de educação musical de crianças, Caldeira Filho comenta ainda sobre cursos que estavam sendo oferecidos na cidade de São Paulo. Aponta práticas que considerava adequadas no Curso Infantil do Conservatório Dramático e Musical de São Paulo, sob a direção de Heloisa G. Fagundes, e no Jardim Escola São Paulo, onde eram responsáveis as professoras Eva Kovach e Geni Marcondes. Visto que a contribuição de Caldeira Filho está intimamente ligada aos demais conteúdos 
explorados em nossa tese, retornaremos à sua publicação mais adiante, em seção específica.

\section{(b) Temas}

A identificação de temas na RBEP se deu a partir da leitura dos textos que, como já apontamos, constituem um conjunto menos numeroso que aqueles das demais revistas. Apresentamos na tabela a seguir os temas com mais de uma ocorrência, de maneira a dar uma visão geral dos conteúdos encontrados. Comentaremos os assuntos mais assíduos, com especial atenção àqueles que se ligam diretamente à presente tese.

\begin{tabular}{|l|l|}
\hline Tema & Quantidade de ocorrências \\
\hline Formação de professores & 8 \\
\hline Escuta/ apreciação & 5 \\
\hline Folclore/ músicas de outras culturas & 4 \\
\hline Educação do gosto & 3 \\
\hline Criação & 2 \\
\hline Manossolfa & 2 \\
\hline Diferença entre educador e musicista & 2 \\
\hline Música e sociedade & 2 \\
\hline Rádio & 2 \\
\hline Currículo & 2 \\
\hline
\end{tabular}

Tabela 13 - Temas de educação musical identificados na RBEP

A formação de professores aparece como tema mais recorrente. De suas oito ocorrências, seis dizem respeito a textos oficiais ${ }^{102}$ que dispõem sobre a formação

102 Portaria ministerial n.215, de 18 de abril de 1945. "Dispõe sobre as condições para o exercício de professores de canto orfeônico nos estabelecimentos de ensino sob fiscalização federal" (PORTARIA, 1945, p. 462).

Portaria n.586 de 3 de dezembro de 1945. "Dispõe sobre o processo de autorização para funcionamento e de reconhecimento de estabelecimentos e cursos particulares de ensino de canto orfeônico" (PORTARIA, 1946, p.167).

Leis Orgânicas do Ensino Primário e do Ensino Normal - Diário Oficial da União de 14 de janeiro de 1946 (LEIS, 1946). Música e Canto Orfeônico constam no programa. 
para o ensino de Canto Orfeônico, sendo um sobre a formação geral de educadores em curso Normal e um específico para o trabalho com crianças cegas.

As demais menções à formação de professores aparecem nos textos de Caldeira Filho (1945) e Vanett Lawler (1946). O artigo de Caldeira Filho é especialmente dedicado às especificidades da educação musical de crianças pequenas e parte da constatação de que as educadoras em formação necessitavam de preparo especial para lidar com a área. Daí sua indicação do trabalho de Coleman e o relato de ter levado suas alunas a visitas de observação em cursos de iniciação musical na cidade de São Paulo.

No texto de Lawler (1946), que tem caráter de relatório, podemos encontrar considerações acerca da formação dos educadores musicais nos diferentes países da América Latina pelos quais ela viajou, através da frequente comparação com os Estados Unidos, seu país de origem e residência. A autora relata que, à época, a formação latino-americana se dava tanto em conservatórios quanto em escolas normais e universidades, e temas como a ênfase na formação musical em detrimento da formação pedagógica e vice-versa já estavam postos. Também é abordada a possibilidade do trabalho ser desempenhado pelos professores não especialistas sob orientação de técnicos em educação musical. A posição defendida no relatório é favorável a este último modelo que, segundo Lawler (1946), estava em vias de ser implantado nos Estados Unidos.

Em se tratando das referências ao segundo tema mais identificado, a escuta/ apreciação, ele também consta em textos oficiais e artigos de educadores. Destacamos duas de suas ocorrências, a saber: na Portaria $n^{\circ} 1$, de 5 de janeiro de 1946, que dispõe sobre a formação de educadores para o trabalho com crianças cegas, e no texto sobre a escola primária dos Estados Unidos, assinado por Williard S. Elsbree.

Na Portaria supracitada - assinada por Heitor Villa-Lobos, na condição de diretor do Conservatório Nacional de Canto Orfeônico - a atividade de escuta é evocada em dois momentos distintos e dignos de nota. Tratando-se de direcionamento para instituições especiais, encontramos na seção que apresenta um pequeno

Portaria $\mathrm{n}^{\circ} 1$, de 5 de janeiro de 1946. Portaria sobre especificidades para a formação de educadores que atuarão em estabelecimentos destinados ao ensino de cegos (VILLA-LOBOS, 1946, p. 408).

Portaria $\mathrm{n}^{\circ} 300$ de 07 de maio de 1946. "Aprova instruções e unidades didáticas do ensino de canto orfeônico nas escolas secundárias” (PORTARIA, 1946, p. 195).

Decreto-Lei no 9494, de 22 de julho de 1946 Lei orgânica do ensino de Canto Orfeônico (RBEP, 1946, vol. IX, n. 24, p. 171). 
programa do ensino pré-primário/ jardim da infância - o que atualmente denominamos educação infantil - os dois pontos seguintes:

Historietas e palestras sobre os sons da natureza do Brasil: canto dos pássaros, dos grilos, sapos e outros bichos, efeitos nos bambuzais, etc., em confronto com a voz humana.

$[\ldots]$

Audições de discos ou rádios, de músicas selecionadas, de acordo com a mentalidade da classe, observando cuidadosamente, em cada aluno, os efeitos causados pelos vários gêneros de músicas aplicadas e anotando-se os resultados fisiológicos e psicológicos na ficha de terapêutica escolar (VILLA-LOBOS, 1946, p. 409)

O primeiro ponto nos fez optar pelo uso do termo "escuta" juntamente à "apreciação", pois se trata de direcionamento da atividade em contexto não restrito a um ou mais repertórios, mas de escuta de sons da natureza. Apontamos para a inclinação nacionalista, visto que se especifica a atenção aos sons da natureza do Brasil, e, mesmo que tal ênfase na sensibilidade à escuta não musical esteja circunscrita à educação especial de alunos não videntes, acreditamos ser notável a abertura para a consideração das sonoridades do entorno das crianças.

O segundo ponto nos remete à tendência laboratorial associada à educação no contexto da escola nova. A escuta de repertório é aí tomada como ocasião de observação dos "resultados fisiológicos e psicológicos" (Idem) que a música provocaria nas crianças. Não encontramos mais menções à tal ficha terapêutica, o que mereceria uma pesquisa específica sobre os meios e ferramentas de observação das crianças nas escolas e a função do professor nesta situação com ímpeto cientificista.

No texto de Elsbree, de título "A educação primária nos Estados Unidos", também encontramos traços do pensamento escolanovista em aproximação à área de educação musical, porém, sem detalhamentos. O autor se vale da comparação entre escola antiga e escola moderna, colocando essas categorias em relação para opor um ensino de arte e música antiquado - porque focado no desenvolvimento de habilidades técnicas - a outro, então atual, direcionado ao desenvolvimento do "espírito criador" e do gosto. Em suas palavras:

A educação artística não é uma inovação recente da escola primária. A música e o desenho surgiam frequentemente incluídos nos 
currículos das escolas elementares do século passado. Os últimos vinte anos trouxeram, em todo o caso, grandes modificações ao ensino dessas matérias. Enquanto a antiga escola punha em destaque as técnicas da arte, a moderna tem como principal finalidade a formação do gôsto pelas artes em cada fase da vida diária dos alunos. A educação na manipulação e uso dos vários processos artísticos é normalmente proporcionada, mas apenas como meio de formar o espírito criador e o gôsto. Consideram-se, pois, a habilidade e a técnica como meios e não como verdadeiras finalidades.

Os mesmo princípios gerais aplicam-se ao ensino da música; desenvolvimento de qualidades de apreciação e capacidade de gôzo. O fonógrafo e o rádio têm contribuído muito para a realização de tais objetivos (ELSBREE, 1947, p. 270)

O autor menciona o deslocamento do foco nas habilidades técnicas e a então recente assunção delas como meio, não mais como fim, porém não esclarece como se forma o desejado "espírito criador". É ainda mais vago quando defende o ensino moderno de música, o qual simplesmente associa à apreciação e à fruição, sem qualquer referência à tal revisão do lugar das habilidades técnicas. O signo de modernidade aparece, apenas, materializado nos objetos de difusão sonora, ainda com ares de novidades tecnológicas naquele momento.

O folclore e as músicas de outras culturas aparecem, mas não se desenvolvem como tema de interesse. Suas menções em textos legislativos o tomam como repertório necessário porque fundador da música brasileira, como a música ameríndia ou africana, mas sem aprofundamento argumentativo ou prescritivo. No texto de Lawler (1946), a autora relata que o folclore é fortemente presente nas escolas latinoamericanas pelas quais passou e que a educação musical baseada em repertório de tradição popular aproximava a cultura de fora da escola à instituição, motivando os estudantes. A autora (1946) também relata algumas ações de ministérios da educação para a organização de coletâneas e promoção de repertório folclórico.

O tema que ocupa o interesse central de nossa tese - a criação - é abordado apenas duas vezes: no relatório de Lawler (1946) e no artigo de Caldeira Filho (1945). Em ambas as menções, não se discute a criação musical ou seu espaço no ensino. Lemos apenas, no texto de Lawler, um elogio a um projeto visitado, mas não elucidado: "O excelente trabalho de educação musical que vem sendo realizado na Escola Modelo da Universidade de Porto Rico é digno de registro, sobretudo, porque tem em vista estimular a imaginação criadora das crianças" (LAWLER, 1946, p. 44, 
grifos nossos). No artigo de Caldeira Filho, a criação aparece na referência ao trabalho de Coleman, que traduz por Música Criadora; em indicações de improvisações feitas pelas crianças, em meio ao relato das visitas às classes de musicalização que observou com suas alunas, então professoras iniciantes; e, ao fim, o autor qualifica de criador o trabalho desenvolvido pelas professoras observadas, alegando que nada havia sido feito de tal natureza anteriormente e que pouco se poderia tirar de livros. Mesmo que em perspectiva de comparação, Caldeira Filho (1945) afirma que as professoras de São Paulo estavam criando algo original e em sintonia com a realidade da criança brasileira.

O material recolhido na RBEP é sobremaneira escasso, principalmente se comparamos às demais revistas utilizadas na presente tese. Além de pouco numeroso, o conteúdo relacionado à música é em grande parte de natureza legislativa, o que significa que são textos de escrita diferente daquela de artigos argumentativos, que apresentam discussões sobre um tema. Dos cinco textos identificados que não tinham caráter oficial, dois tratavam da educação musical de maneira periférica, apenas como um ponto da educação fundamental ou infantil nos Estados Unidos (ELSBREE, 1947; BAIN, 1948). Apenas três artigos tinham a educação musical como tema central: o relatório de Lawler (1946) e os artigos de jornal de Antônio Bento (1946) e Caldeira Filho (1945).

Essa escassez de materiais, no entanto, não impossibilitou nossa investigação sobre a circulação de ideias pedagógicas escolanovistas em educação musical. É, na verdade, de grande relevância para nossa pesquisa o fato de que, mesmo em corpo documental menos numeroso e consideravelmente distinto dos demais, a presença de uma proposta de educação musical declaradamente progressista e representativa do contexto de renovação escolar como a de Satis Coleman tenha sido identificada. Isso nos sugere que seu protagonismo não ficou limitado ao movimento estadunidense, atingindo a rede internacional ao menos na França, na Inglaterra e também no Brasil. A identificação de uma mesma figura também aponta para a coerência que a imprensa pedagógica adquiriu naquele momento, mesmo com as consideráveis diferenças entre os países e os projetos das revistas. O artigo assinado por Caldeira Filho, publicado no jornal O Estado de São Paulo e, em seguida, na RBEP, é apenas um esforço do 
músico na divulgação do trabalho de Coleman. Tratamos, na sequência, da presença desta educadora no cenário brasileiro.

\subsection{Música Criadora: Coleman por Caldeira Filho}

No primeiro texto dedicado especificamente à educação musical na Revista Brasileira de Estudos Pedagógicos, de título "Educação musical infantil”, assinado por João Caldeira Filho (1945), lemos considerações acerca do trabalho com crianças pequenas, entre três e seis anos de idade. A consciência da falta de preparo para tal trabalho expressa por educadoras em formação - o que o autor relata no início do artigo - era, para ele, positiva, pois sinal de que já se pensava a iniciação musical de crianças pequenas para além do "plano necessariamente rígido dos conservatórios" (CALDEIRA FILHO, 1945, p. 120) e de que o ensino de piano não era mais tomado como impreterível nesta etapa. O autor defende que tal trabalho depende de formação pedagógica, convívio com crianças e conhecimento do que já havia sido feito e do que vinha sendo desenvolvido na área, e é aí que apresenta Coleman como referência: "O que de melhor conheço neste sentido é a chamada "Música Criadora", da professora norte-americana Satis N. Coleman (Creative Music for Children, G. P. Putnam's Sons, New York and London)" (CALDEIRA FILHO, 1945, p. 120).

Caldeira Filho apresenta o livro como um relato dos experimentos em educação musical de Coleman com crianças. Experimentos esses, o autor enfatiza, impulsionados pela frustração vivida pela própria educadora na infância, quando quis estudar música e teve a prática instrumental bloqueada por um ensino completamente calcado na leitura de partituras. Além da indicação bibliográfica e da breve observação sobre as motivações da autora, Caldeira Filho acrescenta:

Não é possível resumir aqui o seu livro nem mesmo o que dêle emerge como princípios fundamentais. O que caracteriza o método, para só mencionar o que no momento nos interessa, é não ser uma introdução ao estudo do plano pela aprendizagem interessante da teoria. Ao contrário, é profunda e completa musicalização da criança, aproveitando-lhe tôdas as disposições, capacidades e intêresses para uma vida melhor, mais significativa, de maior valor pessoal e social. Tal método está hoje largamente difundido nos Estados Unidos. O leitor interessado encontrará um resumo no meu livrinho "Música Criadora e Baladas de Chopin", cuja primeira 
parte é dedicada a vulgarizar o método de Satis N. Coleman (CALDEIRA FILHO, 1945, p. 121, grifo no original)

O livro de Caldeira Filho havia tido primeira edição dez anos antes, em 1935, quatro anos após seu retorno de temporada de estudos em Paris, onde permaneceu de 1927 a 1931. Não encontramos, em nossa investigação, nenhum indício de viagem de Caldeira Filho aos Estados Unidos ou de divulgação anterior de Coleman no Brasil, nem mesmo o autor esclarece por qual via teve acesso ao trabalho. Apesar de ter como objetivo de sua viagem à capital francesa o estudo de performance ao piano tendo sido aluno de Isidor Philipp e Marguerite Long -, parece-nos digno de nota o fato de estar Caldeira Filho na Europa no momento em que o trabalho de Satis Coleman era lido e comentado e servia de inspiração na imprensa pedagógica do movimento escolanovista, ao menos na França e na Inglaterra, como mostramos nos capítulos anteriores.

Em segunda edição de Música Criadora e Baladas de Chopin - não datada, mas certamente anterior ao ano de 1964, visto que o exemplar constante da biblioteca da Escola de Comunicações e Artes da Universidade de São Paulo traz dedicatória do autor datada de junho daquele ano -, Caldeira Filho acrescenta uma nota introdutória onde reafirma a importância do trabalho de Coleman no cenário internacional e o compromisso com a educação infantil como motivo de sua divulgação. Em suas palavras:

\begin{abstract}
A reimpressão dêste livrinho, tantos anos após seu lançamento, justifica-se pelo fato de, quanto à parte de iniciação musical, nada ter surgido melhor do que o processo que a autora, Miss Coleman, denominou com muita propriedade "Música Criadora". Não desconheço o que a respeito se tem editado no País e no estrangeiro, o que reforça tal convicção. É exato que em 1935, data do aparecimento dêste trabalho, a situação da música nas escolas era menos favorável do que a de hoje; temos de registrar os progressos trazidos principalmente pelo Canto Orfeônico. Restava, porém, o curso pré-primário, onde o progresso foi mínimo, não obstante a existência de alguns cursos de formação de professores para êsse grau. Daí esta reimpressão (CALDEIRA FILHO, n.d, p. 5)
\end{abstract}

A alusão à formação profissional é observada tanto no artigo da RBEP quanto no livro em questão e isso se deve ao fato de ter Caldeira Filho desempenhado, para além de sua carreira de escritor, intensa atividade de ensino. Além de assinar uma 
coluna de crítica musical no jornal O Estado de São Paulo por mais de 30 anos e de publicar diversos livros de musicologia e traduzir e divulgar obras estrangeiras, Caldeira Filho foi professor do Conservatório Dramático e Musical de São Paulo nos anos que antecederam e se seguiram à estadia em Paris, até que, em 1937, assume o cargo de professor de Canto Orfeônico no Instituto de Educação Caetano de Campos. Nesta instituição - onde permanece até a aposentadoria, em 1964 -, atua diretamente na educação básica ${ }^{103}$. Ainda que não tenhamos indícios seguros de que tenha atuado no curso normal de formação de professores, o artigo da RBEP trata de trabalho com algumas alunas que se iniciavam no ensino de música para crianças.

Mesmo que a orientação de professoras iniciantes tenha se dado em âmbito de ensino privado de piano, é possível afirmar que sua divulgação do trabalho de Coleman teve inserção na supracitada instituição em seus cursos de formação profissional. A segunda edição de Música Criadora e Baladas de Chopin, além de ter nota introdutória do autor e prefácio de Mário de Andrade, é também precedida de pequeno texto intitulado "Um livro orientador", assinado por Frederico de Chiara, a cuja identificação se segue: "Professor do Curso de Formação de Professores Primários do Instituto de Educação Caetano de Campos e dos cursos de Especialização e de Aperfeiçoamento do mesmo estabelecimento" (CHIARA, n.d., p. 16). Chiara (n.d.) afirma expressamente que o tema da educação musical nos cursos profissionalizantes em que estava envolvido era inspirado na divulgação da Música Criadora de Coleman por Caldeira Filho e que, assim, obtinham "os melhores resultados" (CHIARA, n.d., p. 15).

A essa forte evidência, acrescentamos um pequeno vestígio da presença de Coleman na instituição: entre os dossiês pedagógicos do Acervo Histórico da Escola Caetano de Campos, onde estão organizados materiais que compunham a biblioteca da escola, encontramos uma partitura de canção atribuída à educadora estadunidense. Na pasta de nome "Orfeão", cuja última organização na biblioteca data de 1953, encontram-se diversas partituras de pequenas canções. O repertório é constituído de publicações feitas por editoras e também de partituras feitas à mão, mimeografadas.

\footnotetext{
${ }^{103}$ Nas listas de docentes constantes no livro "Caetano de Campos: a escola que mudou o Brasil", de Patrícia Golombek (2016), João Caldeira Filho aparece no quadro do curso ginasial das décadas de 1940, 1950 e 1960 como professor de Canto Orfeônico.
} 
Entre estas, consta uma canção de melodia simples, com oito compassos e em tonalidade de Fá Maior, atribuída a Satis N. Coleman ${ }^{104}$.

Além da indicação de influência de Coleman no Instituto Caetano de Campos, lemos na Introdução de Mário de Andrade - mantida da primeira edição, logo, datada originalmente de 1935 - que suas ideias já estavam em prática no Curso Infantil do "nosso Conservatório" (ANDRADE, n.d., p. 8). Andrade faz referência ao Conservatório Dramático e Musical de São Paulo, onde teve Caldeira Filho como aluno, assistente e colega de docência. O Curso Infantil deste Conservatório tinha em 1945, ano de publicação do artigo na RBEP - direção de Heloísa Grassi Fagundes, professora que também desempenhou a função de diretora do Jardim de Infância da Escola Normal Caetano de Campos. Na mesma Introdução, Andrade afirma que o livro de Caldeira Filho se inseria em um contexto de intensa produção de bibliografia de didática musical em São Paulo. Tal atividade editorial se originava, segundo ele (n.d., p. 7), de dois polos principais: "a sistematização oficial do ensino de música nas escolas públicas do Estado e o Conservatório”. Tanto Caldeira Filho quanto Heloísa Grasse Fagundes estavam imbricados neste cenário paulistano apontado por Andrade.

$\mathrm{Na}$ Introdução, Mário de Andrade justifica a contribuição de Caldeira Filho a essa crescente bibliografia didática pela fragilidade da formação dos professores à época. Andrade se volta contra o que ele chama de empirismo didático. Segundo ele (n.d.), à docência ainda não se dava a devida atenção no Brasil e o professor se formava de maneira improvisada, independente e sem conexão com o que se desenvolvia na área. Em suas palavras:

O professor aqui, as mais das vêzes improvisa-se professor. E depois, quando com o correr pesado dos anos consegue enfim adquirir uma certa prática de ensino, pura prática sem sistematização nenhuma, no geral já se está fazendo coisa nova no mundo, e êle é um indivíduo dessa pior velhice que existe, a de não saber que hora está soando (ANDRADE, n.d., p. 8 -9)

A figura do professor de música brasileiro é assim apresentada por Andrade, em uma perspectiva comparada, como símbolo de amadorismo e desatualização. É interessante ainda notar que, ao mesmo tempo em que evoca uma necessidade de modernização, Andrade atribui esta situação a um déficit de tradição. O empirismo

${ }^{104}$ Dossiê n. 704, documento n. 17. 
então denunciado seria “[...] uma das maldições de país novo e sem cultura tradicional" (Idem, p. 8). A divulgação do trabalho de Coleman era, para ele (Idem, p. 10), "utilíssima”, propagando "uma doutrina didática nova e muito lógica” (Idem) e contribuiria para a abertura de espírito dos professores, para a resolução de problemas de alunos de todas as idades. As atribuições de novidade e caráter lógico garantiriam, de acordo com esta Introdução e com o ímpeto modernista de Andrade, um ajuste de ponteiros entre o ensino de música no Brasil e no estrangeiro.

Quanto ao livro de Caldeira Filho, não se trata de uma tradução, mas de um texto original com intuito de divulgação. Refere-se expressamente, como no artigo da RBEP, ao livro Creative Music for Children, publicado nos Estados Unidos e na Inglaterra em 1922 e do qual já tratamos no capítulo 2 da presente tese. Mesmo que a publicação do livro do autor brasileiro seja de 1935 e sua menção em artigo, de 1945, não encontramos nenhuma menção de Caldeira Filho às demais obras que Satis Coleman já havia lançado nas décadas de 1920 e 1930. Identificamos, contudo, tanto no livro quanto no artigo brasileiro, sugestões que não parecem vir do trabalho da estadunidense, ao menos não dos diversos materiais que compõem nossa bibliografia. Assim, acreditamos que, mesmo em posição de divulgar nomeadamente a obra de Coleman, o discurso e as referências de Caldeira Filho têm um espaço para a hibridização, não se limitando a uma transposição direta.

No artigo de 1945 essa abertura é explícita, visto que o autor parte da leitura de Coleman com suas alunas para a observação de cursos de música para crianças pequenas em São Paulo. Na breve descrição do que veem, surgem estratégias didáticas que, senão completamente ausentes nas propostas de Coleman, tampouco ocupam um lugar minimamente notável, podendo até mesmo ser consideradas divergentes. São exemplos disso a leitura de partitura como conteúdo do curso de iniciação, feita por cores - como exposto em nosso capítulo 2, o processo de leitura em Coleman deriva da necessidade de notação das composições das crianças e se dá por sistema numérico -; o solfejo pela técnica da manossolfa; exercícios de percepção, etc. Há, ainda, uma observação de que a construção de instrumentos, ponto central da proposta de Coleman, não era julgada pertinente pois as instalações não estariam preparadas para tal atividade. Ao fim do artigo, Caldeira Filho (1945) assume que o trabalho descrito é original das professoras de São Paulo, elogiando-as e afastando-se, assim, de uma perspectiva limitada à comparação. 
Na escrita do livro, entretanto, o objetivo específico é a divulgação do trabalho de Coleman. Assim, os desvios são muito sutis e não referenciados, mantendo-se Caldeira Filho bastante fiel aos princípios da Creative Music. Destacamos três pontos de ênfase do autor brasileiro e que retratam satisfatoriamente a obra de Coleman, a saber: a perspectiva evolucionista; a assunção do caráter progressista da proposta, em oposição ao que o autor chama de "educação estática" (CALDEIRA FILHO, n.d., p. 63); e a denúncia da inadequação do estudo sistemático do piano, então em voga, aos primeiros anos da infância. Não nos dedicaremos aqui a descrever com detalhes a proposta, visto que o trabalho de Coleman já foi foco de nossa atenção no capítulo sobre a Educação Musical e a Progressive Education. Vejamos apenas como Caldeira Filho aborda esses e outros aspectos da Creative Music.

O conteúdo da parte do livro dedicada à Música Criadora é organizado em capítulos, cujos título são os seguintes: (1) O problema da Educação Musical; (2) O problema da Educação Musical, sua solução na Escola; (3) Como estabelecer um programa de aprendizagem para a Música Criadora; (4) Desenvolvimento do senso rítmico pela Música Criadora; (5) O controle da voz; (6) Do canto aos instrumentos; (7) Construção de instrumento pelas crianças; (8) A música criadora no lar e (9) Conclusão.

$\mathrm{O}$ autor inicia seu livro com o mesmo discurso que move as justificativas para a educação musical nos cenários estadunidense e francês: a constatação de que a sociedade estaria afastada da música. A educação não diz respeito apenas à infância, mas a uma necessidade de musicalizar a sociedade de uma maneira geral, que se encontraria indiferente e apartada das produções musicais. Esse quadro não deriva necessariamente de uma falta de oferta de educação musical - o autor afirma que, naquele momento, em São Paulo, havia aprendizes de todos os graus e "aos milhares" (CALDEIRA FILHO, n.d., p. 20) - nem de diferenças socioculturais ${ }^{105}$, mas estaria ligado ao ensino baseado na imposição. Ao que a proposta de Coleman se opõe por caracterizar-se pela assunção da música como meio de expressão das crianças.

É que a música, pronta e acabada, tem sido imposta ao educando. Êste a recebe passivamente, isto é, tem que aceitar, como suas, as

\footnotetext{
${ }^{105} \mathrm{O}$ autor (n.d.) sustenta que repensar os princípios do ensino é mais fundamental que explicar o afastamento entre população e música pelas diferenças socioeconômicas. Segundo seu argumento, sendo a música imposta, não atinge nem operários nem os ouvintes que, mesmo frequentando assiduamente salas de concerto, o fazem de maneira dissimulada e indiferente.
} 
expressões alheias de beleza, muito belas, sem dúvida, mas demasiado elevadas para a sua capacidade atual de compreensão. $\mathrm{O}$ aluno de música não teve a oportunidade de exprimir pela música, através da música criada por êle, e executada em instrumentos que êle construiu, a sua personalidade (CALDEIRA FILHO, n.d., p. 21)

Nos dois primeiros capítulos, Caldeira Filho apresenta essa situação como problema e localiza a origem na maneira como a música é apresentada às crianças nos primeiros anos de escolarização. Estando ali o problema, deveria estar também ali a solução. O autor aponta como artificiais e impositivos os métodos de ensino que, desde o início, estão centrados na prática de instrumentos como piano ou violino, o foco precoce na teoria e, na escola primária e no jardim de infância, o canto em conjunto de "alguns hinos patrióticos, com o que nenhum resultado se pode conseguir" (Idem, p. 25 - 26). Essas seriam situações de ensino onde as crianças estariam em uma posição de passividade, sem lugar para criação e livre expressão. $\mathrm{O}$ método de Coleman, segundo a apresentação do autor em termos de evidente cunho escolanovista, "exige essencialmente o deslocamento do centro de interesse, da música para a criança, da arte para o futuro artista” (Idem, p. 26).

A crítica às práticas pedagógicas julgadas antiquadas é acompanhada pelo argumento evolucionista que compara crianças a povos considerados primitivos. Este traço do trabalho de Coleman, discutido em nosso segundo capítulo, é mantido fielmente por Caldeira Filho e aparece algumas vezes durante o livro. O olhar positivo sobre as práticas musicais de outros povos é associada a uma suposta naturalidade destas, o que se buscava também na nova proposta de educação musical. No entanto, essa naturalidade não seria fácil de alcançar em contexto pedagógico. É nesta tensão que se buscam alternativas à organização de um programa sem imposição e se colocam em questão os processos de ensino e de aprendizagem, pontos evidentes na redação de Caldeira Filho, quando passa do segundo para o terceiro capítulo: "Mas, como estabelecer em minúcia um programa para o ensino (esta palavra começa a soar mal agora...) da música? Como determinar os diferentes estágios dêste aprendizado?" (Idem, p. 29, grifo no original).

A resposta consiste na elaboração de um programa que parta da atividade das crianças, em conformidade com suas especificidades e sem ser guiado por uma atitude impositiva por parte do professor. Este deve ser responsivo, estar atento às respostas que as crianças dão aos estímulos. Nos capítulos 4, 5, 6 e 7, Caldeira Filho apresenta 
atividades que integram canto, movimento, construção e prática instrumental, tal qual no livro de Coleman. Ainda que organize sua exposição em temas, admite, como Coleman, que não há uma sequência exata a ser cumprida. Reforça a ideia de que o piano não deve ser tomado como instrumento de iniciação e, ao defender uma atitude de pesquisa das crianças, reproduz um exemplo revelador do caráter inovador da proposta dado por Coleman (1922): o caso da menina que descobriu as possibilidade musicais de um cacto.

Apesar de não dedicar um capítulo à atividade de criação, tal como consta no livro da educadora estadunidense, o tema aparece algumas vezes em seu texto. Destacamos o trecho a seguir, onde a criação aparece como via de realização de um projeto de educação musical que pretende ser expressivo e não impositivo:

Em todos esses estágio é preciso não desprezar nenhuma oportunidade de criação original que a criança encontre. A sua atividade criadora, estimulada pelo interêsse e pelo prazer, poderá chegar a resultados ricos de experiências, a expressões do muito que está dentro dela mesma (auto-expressão) e a gozar com a criação (expressão) alheia (CALDEIRA FILHO, n.d., p. 39)

Assim como em Coleman e ainda outros educadores do cenário, a prática musical em família é defendida como mais valiosa que a escuta de música gravada. Sugere-se que a música em casa pode ser feita com objetos do cotidiano, bem como com instrumentos construídos pelas próprias crianças. A justificativa para a ação das famílias se dá pelo fato de que nem todas as crianças pequenas tinham acesso à escola de educação infantil, assim, caberia aos pais empreenderem esforços para que a Música Criadora fosse oportunizada aos seus filhos nos seus lares.

Após a exposição dos pontos que julgou essenciais da proposta de Coleman, Caldeira Filho apresenta uma Conclusão. O autor finaliza sua obra de divulgação retomando algumas distinções que, acreditava, precisavam ser enfatizadas: a distinção entre ensino e aprendizagem; entre estudar piano e estudar música; a "educação estática" (Idem, p. 63) e a educação progressiva. Sobre esse último par, sua diferenciação, bem como a defesa do segundo modelo, consistem no objetivo central do livro. As duas “educações” aqui confrontadas são assim definidas: 
A primeira exige uma adaptação passiva e submissa; a segunda provoca uma criação e reconstrução da experiência pela atividade. Na primeira o professor impera: é o ensino, a girar em torno dos valores adultos; na segunda o aluno age: é a aprendizagem, a ter o seu centro na criança (Idem, p. 63)

O vocabulário conjugado à retórica da negação aparece aqui de maneira a confirmar a consonância com a tendência escolanovista, apresentada anteriormente nesta tese em algumas de suas manifestações. Caldeira Filho divulga a Creative Music no Brasil e, por fim, se pergunta se nosso país encontraria "neste método a solução de seu problema de educação musical" ou se essa exposição faria pensar os responsáveis pela área (Idem, p. 65).

Por mais que algumas propostas de iniciação musical destinadas à infância tenham se desenvolvido na primeira metade do século XX no Brasil, dando início ao que nos nossos dias chama-se correntemente de musicalização, o nome de Coleman parece ter ficado restrito aos escritos de Caldeira Filho. Muitos educadores estrangeiros constituíram e ainda constituem as bases das práticas pedagógicas com crianças pequenas em nosso país - os nomes de Carl Orff, Émile Jaques-Dalcroze e Zoltán Kodály são apenas alguns exemplos que atravessaram o último século com presença constante na formação de professores. Quando se evocam as experiências nacionais, os nomes de Sá Pereira e Liddy Mignone são fundamentais. O pouco conhecimento que se disseminou em relação aos trabalhos de Coleman em cenário internacional nas décadas posteriores às suas atividades, como já abordamos nos capítulos precedentes, se observa também no Brasil. Ainda que tenha sido objeto de dedicação de um autor prolífico como João Caldeira Filho e que tenha servido de fundamentação em uma instituição de formação de professores da importância do Instituto Caetano de Campos, Coleman não é figura celebrada, tampouco conhecida nos dias de hoje. A falta de ecos de sua obra no presente - ainda que não como fundamento para práticas contemporâneas, pois carregada das marcas de seu tempo, mas nos estudos historiográficos - parece-nos injustificada e demanda outras investigações, haja vista seu caráter inovador e sua circulação internacional que comprovamos aqui. 


\subsection{Iniciação Musical: um escolanovismo fora da escola?}

Como já apontamos no primeiro capítulo, tanto em bibliografia secundária quanto nos documentos oficiais, a tendência pedagógica escolanovista é geralmente atribuída aos cursos livres de Iniciação Musical, sendo o Canto Orfeônico associado à educação tradicional. No entanto, se nos dedicamos a analisar com um pouco mais de cautela os termos aí implicados, essa organização em pares correlacionados não se dá sem algum estranhamento.

Refletindo sobre as dificuldades do trabalho historiográfico que tem por objeto o escolanovismo, Ohayon, Ottavi e Savoye (2004) apontam a necessidade de circunscrever princípios claros, mesmo que provisoriamente, uma vez que o termo Escola Nova tornou-se polissêmico. A memória que envolve o objeto é deveras confusa, baseando-se em distintos aspectos dos movimentos pela renovação escolar, como o apelo científico; a posição ética pioneira perante a infância; o foco na individualização da aprendizagem ao mesmo tempo em que se buscava delimitar, por meio de testes e medições, padrões de normalidade e desvios no desenvolvimento; a função da educação no progresso da sociedade, seja pela educação popular, seja pela educação das elites, etc.

A conexão que se estabelece entre Escola Nova e as atividades pedagógicas pioneiras de Sá Pereira e Liddy Mignone - recorte que tomaremos aqui como exemplar - é frequente e não exclusiva de uma construção do discurso historiográfico, pois essa conexão já era mobilizada pelos próprios educadores. O ano de 1937 não foi apenas o ano de fundação do Curso de Iniciação Musical para Crianças no recémcriado Conservatório Brasileiro de Música, no Rio de Janeiro, por Antônio de Sá Pereira, mas foi também o ano de lançamento de seu livro Psicotécnica do Ensino Elementar da Música. A publicação deste livro se insere no contexto de produção de obras didáticas apontado por Mário de Andrade na Introdução ao livro de Caldeira Filho. Andrade já havia, nesta Introdução de 1935, feito referência ao livro precedente de Sá Pereira, Ensino moderno do piano, de 1933.

Em um discurso próximo ao do intelectual paulistano, Sá Pereira justifica sua publicação através da denúncia do quadro de amadorismo no ensino de música à época. Sua ação teria como objetivo contribuir para mudar tal quadro que, segundo ele (1937), não era realidade apenas no Brasil, mas também no cenário estrangeiro. 
No prefácio de sua obra esta posição é estabelecida, bem como a delimitação de seu interesse pela educação na infância.

No vasto domínio da educação creio não haver outro campo em que o arbítrio, a fantasia, o tateio, a confusão e a desordem imperem com tanta sem-cerimônia como no da fase inicial do ensino da música. Entregue, salvo honrosas exceções, a amadores inexperientes, costuma fazer-se a iniciação musical da criança quasi sempre do modo mais contrário à psicologia infantil. As consequências de semelhantes desacertos fazem-se sentir, de modo desastroso, ainda longos anos mais tarde, durante todo o curso do estudante de música.

$[\ldots]$

E sinto certa satisfação em pensar ter feito trabalho útil e original, uma vez que mesmo no estrangeiro quasi nada se tem escrito sobre o assunto, nenhuma obra especializada dele tem cuidado, exceção feita dos trabalhos muito originais de Jaques Dalcroze, de que entretanto só quem tenha pessoalmente frequentado o curso poderá tirar proveito (SÁ PEREIRA, 1937, p. 7 - 8)

Dois fatores essenciais do pensamento do autor nos são dados a ver nessa passagem do Prefácio e se confirmam através do livro: a assunção de que o conhecimento em psicologia é o que está na base de uma boa prática pedagógica e a referência central para ele, no campo da iniciação musical, de Jaques Dalcroze. Em sua primeira permanência significativa para formação na Europa, entre os anos de 1900 e 1917 - passando pela Alemanha, França e Suíça e diplomando-se em química, além dos diversos estudos musicais -, Sá Pereira já havia entrado em contato com a abordagem dalcroziana. Em 1936, o brasileiro estabelece contato efetivo com Dalcroze durante um congresso de Educação Musical em Praga, e visita Genebra logo em seguida (CORVISIER, 2011). Este vínculo se estabelece, portanto, às vésperas da fundação do Curso de Iniciação Musical do CBM e da publicação de Psicotécnica do Ensino Elementar da Música.

Ao lado de Sá Pereira, no início do Curso de Iniciação Musical do CBM, estava Liddy Chiaffarelli Mignone ${ }^{106}$. Pouco tempo depois o educador assume cargos na Escola Nacional de Música da Universidade do Brasil ${ }^{107}$, onde funda um curso

\footnotetext{
${ }^{106}$ Segundo Rocha (2017), Liddy teria criado o curso juntamente com Sá Pereira. Corvisier (2011), por sua vez, a apresenta como assistente do educador. O protagonismo de Liddy é, entretanto, inconteste a partir de 1938.

${ }^{107}$ Renomeados ainda em 1937, antes Instituto de Música e Universidade do Rio de Janeiro (CORVISIER, 2011).
} 
semelhante, ficando Liddy Mignone responsável pelo curso pioneiro. A musicista nasceu e se formou em São Paulo, porém, assim como Sá Pereira, em contexto educativo sobremaneira europeizado. Filha de Luigi Chiaffarelli, figura de grande destaque no meio musical à época, não frequentou escolas. Sua educação domiciliar, notável nos âmbitos musical e linguístico - Liddy era pianista, cantora e dominava cinco idiomas -, foi responsabilidade de seu pai e se deu em um contexto de elite intelectual, próprio à cidade de São Paulo dominada pela burguesia cafeeira do início do século passado. Liddy viveu nesta cidade até 1933, quando se mudou para o Rio de Janeiro, onde consolidou carreira destacada em Educação Musical.

O final da década de 1930 é, assim, palco da implantação de uma proposta inovadora em educação musical infantil na capital do país, baseada sobretudo em influências europeias. Além da ligação evidente entre Sá Pereira e Dalcroze, Rocha (2017) registra que Liddy Chiaffarelli Mignone tinha conhecimento do que havia de mais contemporâneo na Europa em educação musical, tais como as propostas de Dalcroze, Carl Orff e Maurice Chevais, visto que viajava constantemente para aquele continente e lia correntemente em alemão, italiano, francês e inglês.

Foi apenas em 1942 que ambos se reportaram de maneira direta à educação musical estadunidense. Neste ano, os dois educadores participaram do VIII Congresso Bienal de Professores de Música, em Milwaukee, Wisconsin. Além do evento, ambos visitaram escolas regulares e de música, conhecendo projetos de educação musical sobre os quais teceram comentários elogiosos. Liddy foi central, ainda, para a promoção da obra de Francisco Mignone - um dos objetivos da viagem -, pois desempenhou a função de tradutora do marido (ROCHA, 2012b). As impressões da jornada por diversas cidades dos Estados Unidos são acessíveis através de correspondência enviada por Liddy Mignone a Mário de Andrade (ROCHA, 2012a, 2012b) e por publicação de Sá Pereira do mesmo ano, intitulada Mobilização musical da juventude americana (impressões de viagem).

Em ambos os materiais encontram-se informações sobre o evento e as impressões dos educadores sobre o que viram. A educação musical estadunidense é retratada de maneira muito positiva se em comparação com a brasileira, mas não apenas. Sá Pereira, para além dos elogios ao engajamento e à qualidade técnica demonstrada pelas crianças e jovens observados, comenta a abertura para repertórios latino-americanos como atitude política em contraposição ao nacionalismo europeu, referindo-se, nomeadamente, a experiências que teve na Alemanha nazista na década 
anterior. Outro comentário digno de nota do músico brasileiro diz respeito à forte presença feminina nas bandas e orquestras, meios que, ele admite, estavam predominantemente ocupados por meninos e homens nas formações brasileiras (SÁ PEREIRA, 1942).

Dentre os materiais que relatam e comentam tal viagem, não encontramos nenhuma menção ao trabalho de Satis Coleman. Nem mesmo alusões à Lincoln School ou ao Teachers College da Columbia University. Tampouco a Progressive Education Association aparece nos escritos dos brasileiros. Da mesma forma, o congresso não teve destaque na revista da associação, o que nos faz pensar que o evento não integrou este movimento de renovação pedagógica, ao menos não de maneira significativa. $\mathrm{O}$ único ponto de consonância nesta ocasião, em ambos os materiais, é a Política de Boa Vizinhança subjacente. A aproximação entre Estados Unidos e Brasil é a oportunidade para o intercâmbio dos músicos e, da mesma maneira, justifica as referências interessadas à América Latina e ao Brasil na revista naquele momento.

É imperativo, ao pensar nas décadas de 1930 e 1940, seja nas relações de estética e modernidade entre o Brasil e a Europa, seja nas relações políticas entre nosso país e os Estados Unidos de Roosevelt, reconhecer a proeminência de Heitor Villa-Lobos. No âmbito da Educação Musical, seu projeto de Canto Orfeônico encontrou espaço oficial para a implantação na educação básica, mesmo que destoando consideravelmente do pensamento escolanovista, predominante à época. De acordo com a incompatibilidade deste projeto de educação musical com o tema que investigamos, não nos aproximaremos dele de maneira a analisá-lo. Interessa-nos, por outro lado, mais do que a forte presença de Villa-Lobos no quadro, o silêncio sobre sua face educativa nos escritos de Liddy Mignone e Sá Pereira, silêncio este oportunamente percebido e sublinhado por Rocha (2012a, 2012b).

Mesmo que não haja uma explicação evidente para o fato de nenhum dos dois educadores haver tecido comentários sobre o Canto Orfeônico, nem mesmo em correspondências privadas - as quais, reconhecemos, constituem fonte muitas vezes lacunares e demasiado marcadas pela subjetividade de seus autores - , o silêncio de Liddy Mignone e Sá Pereira testemunha, ao menos, sua não adesão ou colaboração com o programa. Os caminhos percorridos por Villa-Lobos e pelos fundadores do Curso de Iniciação Musical do CBM estavam, de fato, pedagogicamente desalinhados. 
Em artigo de Rocha (2012b) sobre a participação dos educadores brasileiros na conferência estadunidense, lemos que um dos organizadores, John W. Beattie, após visita a escolas brasileiras, escreve em carta a outro organizador em 1941 que, ainda que Villa-Lobos fosse um compositor reconhecido, não parecia ser capaz de contribuir significativamente para o evento educativo. As justificativas para não convidá-lo eram as seguintes: sua falta de domínio da língua inglesa, seu desconhecimento da psicologia infantil, a inadequação do trabalho vocal, a prática pedagógica baseada em uso de "métodos de sinais descartados e antiquados" e a falta de qualidade do resultado sonoro de seu trabalho com crianças. O estadunidense desautorizava veementemente Villa-Lobos como educador musical (ROCHA, 2012b, p. 109).

Note-se que, com exceção da língua e dos assuntos propriamente musicais, o fator que desautoriza Villa-Lobos como educador é a falta de conhecimento em psicologia, disciplina que estava no cerne dos discursos sobre a Iniciação Musical. É também a falta de conhecimento em psicologia que denuncia Sá Pereira como marca de amadorismo em educação no Prefácio (1937) já aqui citado. O interesse de Liddy Mignone por tal campo aparece quando comenta os benefícios para o equilíbrio psíquico proporcionado pela prática musical (ROCHA, 2017), na valorização da área em suas atividades como formadora de educadores a partir do final da década de 1940 e na aproximação de profissionais da saúde por meio da educação especial e da inclusão (PAZ, 2013).

Ambos os educadores apresentavam, por meio de suas publicações, conhecimento do que se produzia em se tratando de estudos de psicologia no contexto escolanovista europeu. Assim, estavam imersos em um vocabulário e um pano de fundo epistemológico específico, apropriando-se de ideias e desdobrando-as em propostas pedagógicas. O conhecimento da psicologia infantil para esses educadores constituía-se, sobretudo, como meio para adaptar didaticamente o ensino de música às crianças pequenas.

Não nos dedicaremos à análise pormenorizada destas propostas, contudo, apontamos apenas alguns fatores do trabalho que eram vistos como inovadores e expressam essa busca pela adaptação dos conteúdos musicais julgados então elementares para a primeira etapa de aprendizado sistematizado de música na infância. Um exemplo de atividade atribuída aos educadores é aquela em que a criança deve se deslocar por uma escada ao mesmo tempo e de maneira conectada 
com as notas da escala maior que um adulto toca ao piano. A escada ficava geralmente deitada sobre o chão e os espaços entre os degraus, em dois tamanhos diferentes, correspondiam aos intervalos de tom e semitom. Além da escada, também o uso de objetos de tamanhos diferentes para representar diferentes durações figuram em fotografias e são apontados por Cecília Conde - em entrevista concedida à Ermelinda Paz (2013) - como recursos inventados pela dupla. Estes recursos didáticos constituem adaptação material para o ensino de conteúdos abstratos, assim imbuídos de um aspecto concreto para facilitar o entendimento das crianças.

Por mais que estes exemplos demonstrem considerável inovação didática, ela servia, através de atividades que se aproximam de brincadeiras e materiais que se aproximam de brinquedos, à preparação para o ensino formal posterior, especialmente na preparação para a leitura. Já no Prefácio de Sá Pereira (1937), anteriormente citado, o ensino inadequado na infância era denunciado como motivo de problemas na formação sequente do músico. Ao longo do livro, o autor dá mostras de que suas considerações pedagógicas têm o intuito, mesmo que não explícito, de preparar previamente a criança para o estudo do instrumento, especialmente o piano. $\mathrm{Na}$ conclusão da obra, Sá Pereira (Idem) atribui ao conhecimento da psicologia a possibilidade de organizar o ensino de acordo com as tendências, capacidades e interesses do educando, incluindo-se o autor como agente na era da escola centrada na criança.

Sobre o tema que nos interessa especialmente na presente tese, o incentivo às práticas criativas, parece ter havido alguma abertura neste âmbito, mas não com o enfoque percebido nos materiais analisados nos capítulos precedentes. O tema do estímulo às práticas de improvisação e composição pelas crianças não é abordado de maneira significativa por Sá Pereira nos materiais aos quais tivemos acesso. Rocha (2017) defende que essa abertura já estava presente no pensamento pedagógico de Liddy Mignone, no entanto, refere-se a seus escritos de 1959 e 1960, enfatizando que se tratava de tema que se tornou caro à educadora com o passar do tempo.

Certamente os trabalhos de Liddy Mignone e Antônio de Sá Pereira foram pioneiros e de imensa importância histórica, constituindo as bases do que se desenvolveu posteriormente no Brasil como um olhar pedagógico dedicado às especificidades da música na infância. Contudo, a associação direta entre esta abordagem de Iniciação Musical e a Escola Nova nos parece guardar limitações. 
Retomando um argumento já mobilizado nesta tese, de autoria de Raillon (2004), defendemos que associar a Escola Nova a toda e qualquer manifestação de preocupação com a infância tem consequências negativas, pois desconsidera a importância de refletir sobre suas especificidades. A banalização do termo acaba por apagar sua história, diluindo-o e gerando análises simplistas. Savoye (2004), por sua vez, aponta que um dos desdobramentos da Éducation Nouvelle na França foi a sua vulgarização, acompanhada da perda de seu rigor intelectual e do seu potencial transformador. Neste processo de vulgarização observa-se a crença desmesurada na ligação entre psicologia laboratorial e ambientes de ensino; um discurso demasiadamente positivo, portanto, falho em críticas; a mistificação da espontaneidade da criança; a incorporação de traços da Éducation Nouvelle à rotina escolar, de maneira a descaracterizá-los, transformando-os em técnicas vazias; entre outros aspectos.

Em passagem onde comenta a capacidade prospectiva de trabalhos investigativos acerca da Éducation Nouvelle, Jacquet-Francillon (2012) atenta para a necessária desconfiança constante em relação ao discurso que os sujeitos implicados nos movimentos produzem deles mesmos. Educadores e educadoras envolvidos nos movimentos de renovação pedagógica se apresentaram, de uma maneira geral, como representantes incontestes da inovação. O autor (2012) salienta que estudar suas propostas envolve a reflexão sobre seus limites.

Sublinhamos, então, um fator que nos parece conflitante na associação entre Escola Nova e Iniciação Musical. Este fator é, na verdade, bastante evidente pelos próprios termos envolvidos e já está destacado no subtítulo da presente seção: o escolanovismo em educação musical no Brasil parece ter se dado fora da escola. Porém, seria possível manter os termos correlacionados após tal consideração? Ora, se tomamos a especificidade do movimento brasileiro, a instituição escolar estava em seu nome - Escola Nova ${ }^{108}$-, enquanto os movimentos estrangeiros valeram-se do termo educação - Éducation Nouvelle e Progressive Education. Os intelectuais escolanovistas brasileiros estavam sobremaneira envolvidos com o cenário institucional, ocupando cargos em ministérios e elaborando reformas e demais textos legais. O Manifesto dos Pioneiros da Educação Nova de 1932, mais do que defender

\footnotetext{
${ }^{108}$ Por mais que também se identifiquem termos Pedagogia Nova ou Educação Nova, é evidente o estabelecimento de Escola Nova como termo central, visto que daí derivam também termos como escolanovismo e escolanovista, amplamente utilizados.
} 
uma proposta pedagógica, consistiu na defesa de um projeto universal de educação pública e laica para o país (SAVIANI, 2013). Essa estreita relação entre movimento de renovação escolar e altos escalões institucionais da política educacional é uma especificidade do Brasil. Em outros países, os movimentos caracterizam-se costumeiramente por algum grau de marginalidade. Contudo, tanto em instâncias oficiais quanto em movimentos de organização livre, a renovação pedagógica estava sempre ligada à escola, em um momento histórico crucial para o estabelecimento desta instituição como espaço dedicado e adaptado à infância para todas as classes sociais. Ainda que demorasse décadas, ao menos no Brasil, para que este projeto de universalização da educação escolar se tornasse realidade, as bases se estabeleciam naquele momento.

Entretanto, mesmo que neste cenário renovador, à instituição escolar brasileira coube o projeto de educação musical do Canto Orfeônico. Esse descompasso entre as ideias de educação musical mais inovadoras e a escola tem um de seus motivos elucidado mais uma vez por Cecília Conde, agora em entrevista à Inês Almeida Rocha (2012a). A educadora e ex-aluna de Liddy Mignone esclarece que o diploma conferido aos professores formados pelo Conservatório Brasileiro de Música, mesmo que em curso de especialização em Iniciação Musical reconhecido pelo MEC, "não era aceito pelas autoridades como documento que os habilitasse a fazer concurso público. [...] apenas os diplomas conferidos pelo Conservatório Nacional de Canto Orfeônico eram aceitos" (ROCHA, 2012a, p. 287). Esse era mais um traço da centralização e homogeneização do projeto de Villa-Lobos.

Enfatizamos, ainda, que, além da Iniciação Musical não ter se desenvolvido nem encontrado lugar na escola de educação básica à época, o que causa conflito em sua associação corrente à Escola Nova, a linha que liga esta abordagem específica ao movimento renovador é de natureza teórica muito frágil. Levando em conta todas as características e a complexidade deste momento histórico e dos movimentos pedagógicos que aí se desenvolveram, os deslocamentos políticos, sociológicos e filosóficos que geraram, parece-nos que a simples consideração da psicologia como disciplina importante para a adaptação didática talvez não seja suficiente para sustentar tal associação de termos. Mais ainda, essa associação direta entre Iniciação Musical e Escola Nova não se dá sem incorrer em exacerbada simplificação, o que serve muito pouco à compreensão do contexto. 
Reconhecemos a originalidade grandiosa desses educadores e de seu trabalho. Não se trata aqui, de maneira alguma, de contestá-los em sua importância histórica para a educação musical brasileira. Apontamos apenas que a associação direta entre Escola Nova e Iniciação Musical não é interessante para a construção da historiografia de nossa área porque, de acordo com diversos argumentos apresentados ao longo da presente tese, não é verdadeira. 


\section{Novidades quase centenárias: considerações e apontamentos}

A investigação aqui apresentada partiu da constatação de que as práticas criativas infantis têm reconhecimento bem estabelecido nos discursos sobre Educação Musical das últimas décadas. E, embora relevantes nos textos oficiais e teóricos, não poucas vezes essa valorização é acompanhada de denúncias de sua não efetivação em sala de aula, especialmente em se tratando da escola de educação básica brasileira. A abertura para as criações das crianças nas aulas de música é geralmente associada às inovações do campo composicional do pós-guerra. A música concreta e a incorporação do acaso como elemento criativo, por exemplo, teriam levado a formas inauditas de organizar sonoridades, abrindo caminho para uma nova apreciação das músicas feitas pelas crianças. No entanto, se tomamos o contexto mais amplo da educação, já no início do século $\mathrm{XX}$ as crianças vinham ganhando espaço de participação e expressão em projetos pedagógicos de tendência progressista. Interessou-nos, então, investigar esse aparente descompasso, intentando esclarecer se e como a música esteve inserida em movimentos pedagógicos de renovação escolar.

Tínhamos como hipótese que, se conectada de maneira coerente com o ideário renovador, a educação musical já consideraria as atividades criativas infantis como relevantes nos processos de ensino e aprendizagem. Seguiu-se, então, um trabalho de pesquisa objetivando explorar tal hipótese e delinear os traços de nossa área quando em sintonia com as ideias pedagógicas progressistas. Para tanto, delimitamos como fonte e periodização a imprensa pedagógica no período entre-guerras, mais especificamente, as revistas Progressive Education (Estados Unidos), La Nouvelle Éducation (França) e Revista Brasileira de Estudos Pedagógicos publicadas nas décadas de 1920, 1930 e 1940. Essa escolha se justificou pela importância de tais publicações para a difusão de ideias e relatos de práticas pedagógicas dos movimentos renovadores. Através dos conteúdos aí identificados, pudemos alargar as fontes e encontrar indícios de que a criação musical infantil já tinha espaço no cenário. A educação musical incorporava princípios pedagógicos gerais, desdobrando-os nas particularidades da área e assumindo, de acordo com os limites próprios ao pano de fundo epistemológico e político, ares de inovação.

Esse primeiro quadro composto pela definição do objeto de estudo, pela nossa hipótese e pelas consequentes escolhas metodológicas, bem como pelos pressupostos 
teóricos que guiaram a investigação, foi traçado em nosso primeiro capítulo. Salientamos naquela seção, também, a impossibilidade de estabelecer contornos nítidos para o movimento de renovação pedagógica focalizado, visto que se tratou de uma rede heterogênea no que diz respeito às bases epistemológicas e políticas e estendeu-se por regiões geográficas distantes e distintas. Apontamos, todavia, algumas características que garantem a sua unidade e guiaram nosso estudo, como a circulação internacional de ideias pedagógicas e a importância dos impressos e dos congressos para o estabelecimento e manutenção de trocas entre os educadores envolvidos. Os traços específicos de cada contexto e o fluxo de informação que fazia ecoar experiências particulares em espaços diferentes foram dados a ver nos capítulos seguintes.

O quadro da Progressive Education, movimento estadunidense que publicou revista homônima, constitui nosso segundo capítulo. Ali apresentamos as discussões e experiências empreendidas por educadores musicais estadunidenses envolvidos na associação. O estudo das fontes revelou a existência do trabalho pioneiro de Satis Coleman, o qual ficou conhecido, à época, como Creative Music. Coleman começou seus experimentos pedagógicos com crianças em estúdio particular, mas logo veio a ser responsável pela área de música na Lincoln School, escola laboratório do Teachers College da Columbia University. Essa instituição era fundamental para o movimento renovador nos Estados Unidos e em âmbito internacional, pois acolhia educadores de diversos países em cursos de formação pedagógica. Nessa escola, Coleman desenvolveu uma proposta de educação musical extremamente coerente com o projeto da Progressive Education, tanto em aspectos que ainda hoje são considerados inovadores, como a ampla participação criativa das crianças, quanto em relação à base epistemológica evolucionista, teoria já superada. Seu trabalho guiava diversos educadores pelo país e também era alvo de críticas, pautando de maneira fundamental as discussões da área de educação musical no movimento. Para além da produção de Coleman, a criação musical aparece como assunto primordial na revista analisada, acompanhada de recorrentes considerações sobre repertório e novas tecnologias.

O terceiro capítulo, tendo como foco a educação musical em contexto renovador francês, corrobora pontos observados no estudo sobre os Estados Unidos, ao mesmo tempo em que apresenta suas particularidades. Os assuntos mais recorrentes também estão relacionados à criação, ao repertório e às novas tecnologias, mas a presença da música vocal, sobretudo o estudo do solfejo, mostra-se como um 
traço específico da educação musical na escola francesa. Em relação à prática instrumental, desenvolve-se na década de 1930 um grande movimento pela fabricação de flautas e pela música de câmara, que acaba por ultrapassar o contexto escolar. A presença de Satis Coleman como referência é notável, bem como de Margaret James, inglesa que iniciou o movimento de grupos instrumentais. $O$ fato de a educação musical na associação La Nouvelle Éducation ter como referências as educadoras supracitadas pode ser compreendido pelo papel central de Madeleine Guéritte, editora da revista e diretora da associação ao lado de Roger Cousinet. Guéritte era tradutora da língua inglesa, exercendo também o ofício na publicação de obras literárias, além de residir na Inglaterra. Sua atuação reforçava a tendência internacional do movimento e as conexões que estabelecia entre produções anglófonas tocavam sensivelmente nossa área por ser Guéritte pianista. No que concerne ao foco da presente tese, as atividades criativas de crianças figuram tanto nos textos inspirados em Coleman, quanto em relatos das assembleias da associação La Nouvelle Éducation e das atividades dos grupos de flautas.

No quarto capítulo nos dedicamos ao contexto brasileiro de renovação escolar. A revista tomada como fonte principal para esta seção consistia em material sobremaneira escasso se comparada com as demais. Ressaltamos, ainda, a natureza institucional da revista, publicada pelo INEP, enquanto as outras fontes consultadas partiam de associações livres de educadores. Por esses motivos, a análise da revista brasileira foi muito mais sucinta do que aquelas apresentadas nos capítulos anteriores, o que não impediu a constatação de aspectos relevantes para a compreensão do cenário específico do Brasil e sua relação com o exterior. O aspecto mais notável do conteúdo da revista para nossa tese foi a constatação de que, também aqui, repercutiu o trabalho de Satis Coleman, embora no trabalho de um único autor. No primeiro artigo da publicação que traz o tema da educação musical como assunto central, a Música Criadora de Coleman é exposta de maneira muito positiva por João Caldeira Filho. Apresentamos, então, considerações sobre os esforços de divulgação dessa proposta pelo educador brasileiro. Em conformidade com as características da revista e do próprio movimento escolanovista brasileiro, identificamos grande número de textos legislativos, expressando a presença institucional do Canto Orfeônico como projeto de educação musical escolar. Contudo, ocupando-nos de inovação pedagógica e educação musical no Brasil em tal contexto, era imperativo tratar também dos cursos de Iniciação Musical criados no final da década de 1930. Esses cursos são 
correntemente associados ao movimento escolanovista, mesmo que não tenham se desenvolvido na escola regular. A correlação entre Escola Nova e Iniciação Musical e Escola Tradicional e Canto Orfeônico foi objeto de reflexão e contestação na presente tese. A condição institucional do escolanovismo brasileiro e sua escolha pedagogicamente contraditória pelo Canto Orfeônico, ao lado da constatação, através do estudo dos movimentos renovadores apresentados ao longo de toda a tese, de que as inovações trazidas pela Iniciação Musical eram de grande relevância, mas não bastavam para caracterizá-la como expressão do escolanovismo, nos levou a defender que associações de tal natureza são simplistas e não contribuem para uma historiografia cuidadosa de nossa área. Assumimos, assim, a grande importância dos trabalhos de Liddy Chiaffarelli Mignone e Antônio de Sá Pereira, desvinculando-os, contudo, dos movimentos pedagógicos escolanovistas, na tentativa de mostrar que tal quadro é mais complexo que tais gereralizações.

Ao cabo da investigação, acreditamos ter ficado claro que a educação musical, quando esteve inserida nos movimentos renovadores do entre-guerras, apresentou pontos de coerência com os projetos pedagógicos das escolas progressistas. Evidentemente, houve também pontos de contradição e disputas internas por propostas distintas. Entretanto, seja nos indícios de práticas pedagógicas, seja nas discussões e textos argumentativos, a criação musical das crianças esteve presente como desdobramento coerente do ideário de renovação.

Ao longo da tese, também se evidenciaram pontos que pedem por desenvolvimentos futuros, podendo desencadear estudos mais pormenorizados. Destacamos dois assuntos alcançados pelo nosso trabalho e que, acreditamos, mereceriam ser melhor explorados em outro momento, a saber: a circulação internacional dos trabalhos de Satis Coleman e seu posterior silenciamento, e a dificuldade da educação musical em estabelecer ligações efetivas com a escola de educação básica brasileira.

Em relação ao primeiro ponto, ficam indagações sobre os motivos pela inexpressividade da repercussão do trabalho de Coleman para além de seu tempo, visto que, além de produzir obras numerosas, ela também esteve à frente de uma instituição internacionalmente reconhecida. Pensando a partir de uma perspectiva de gênero, poderíamos nos perguntar a razão pela qual uma mulher com tamanha contribuição para a área não seja estudada, enquanto um quadro predominantemente masculino se reproduz como única representação da educação musical do início do 
século XX. Poderíamos nos perguntar, ainda, se outras educadoras da mesma época não estão também silenciadas e, com isso, perdemos em conhecimento histórico e referências para reflexões contemporâneas.

O segundo ponto convida-nos a pensar sobre o contexto brasileiro específico. A grande contradição entre o pensamento pedagógico escolanovista e o projeto de educação musical assumido institucionalmente naquele momento, bem como o fato de estarem as realizações inovadoras na área, tanto no período aqui analisado quanto nas décadas posteriores, frequentemente à margem da escola de educação básica, deixamnos uma inquietação: o que podemos aprender com a história para a construção de um espaço efetivo para a música na instituição escolar?

Por fim, e daí o nome dessa última seção, acreditamos que os conteúdos identificados em nossa pesquisa e apresentados durante toda a tese nos conectam com as ideias e práticas do entre-guerras e, ao mesmo tempo, nos ajudam a pensar o presente. A contrução de uma escola comprometida com a escuta das crianças, em que elas se formem nutrindo-se do passado e estabelecendo conexões significativas com o mundo contemporâneo, as transformações da prática e da fruição musical pela utilização de novas tecnologias, os repertórios que encontram lugar na educação, são todos temas que nos mobilizam ainda agora. Conhecê-los em sua historicidade pode tornar a elaboração de respostas, se não mais fácil, menos solitária e mais consciente. 


\section{Referências}

\section{Revistas consultadas}

La Nouvelle Éducation, revista da associação La Nouvelle Éducation. Paris, 1924 1939.

Pour l'Ère Nouvelle, revista da Ligue Internationnelle pour l'Éducation Nouvelle. Genebra, 1922 - 1940.

Progressive Education, revista da associação Progressive Education. New York, 1925 - 1944.

La musique à l'école, revista do Organe Corporatif et Pedagogique des Professeurs de Musique. Paris, 1927 - 1939.

Revista Brasileira de Estudos Pedagógicos. Instituto Nacional de Estudos Pedagógicos, Ministério da Educação. Rio de Janeiro, 1944 - 1950.

\section{Demais referências}

ABRANTES, Pedro. Para uma teoria da socialização. Sociologia, Revista da Faculdade de Letras da Univesidade do Porto, vol. XXI, 2011, p. 121 - 139.

ALIX, Sébastien-Akira. L'éducation progressiste aux États-Unis: Histoire, philosophie et pratiques (1876 - 1919). Grénoble : PUG, 2017.

ALTHUSSER, Louis. Aparelhos ideológicos de Estado: nota sobre os aparelhos ideológicos de Estado. Rio de Janeiro: Edições Graal, 1985.

AMAND, L. S. "Listen to these records with the children". Progressive Education, 1943, vol. XX, p. 302.

ANDRADE, Mário de. "Introdução". CALDEIRA FILHO, J. C. Música criadora e balladas de Chopin. $1^{\mathrm{a}}$ ed. $1935,2^{\mathrm{a}}$ ed., n.d., p. $7-14$.

ARENDT, Hannah. Entre o passado e o futuro. Trad.: Mauro W. Barbosa. $7^{\text {a }}$ ed. São Paulo: Perspectiva, 2014.

ARIÈS, Philippe. História Social da Criança e da Família. Trad.: Dora Flaskman. Rio de Janeiro: LTC, 2011.

ARTS populaires et Loisirs ouvriers. La Nouvelle Éducation, n. 155, maio 1937, p. 75 -78 . 
AVIS. La Nouvelle Éducation, jun. 1933, n. 116, p. iv.

BAIN, Winifred E. "Escolas maternais e jardins de infância nos Estados Unidos". Revista Brasileira de Estudos Pedagógicos, vol. XII, n.32, p. 70 - 103, 1948.

BARBOSA, Ana Mae. John Dewey e o ensino de arte no Brasil. $4^{\text {a }}$ Ed. São Paulo: Cortez, 2001.

BARRERA, Thatyana G. S. O movimento brasileiro de renovação educacional no início do século XXI. Tese (doutorado). Faculdade de Educação, Universidade de São Paulo, São Paulo, SP, 2016.

BARROS, José D’Assunção. "História das Ideias - em torno de um domínio historiográfico". Revista de História, Juiz de Fora, v. 13, n.1, p. 199-209, 2007.

BEINEKE, Viviane. Processos intersubjetivos na composição musical de crianças: um estudo sobre aprendizagem criativa. Tese (doutorado). Instituto de Artes, Universidade Federal do Rio Grande do Sul, Porto Alegre, RS, 2009.

BENTO, Antônio. "Música e Educação". Revista Brasileira de Estudos Pedagógicos, vol. VIII, n.23, p. $360-361,1946$.

BONA, Melita. "Carl Orff: um compositor em cena”. In ILARI, B.; MATEIRO, T. Pedagogias em educação musical. Curitiba: Ibpex, 2011, p. 125 - 156.

BOURDIEU, P.; PASSERON, J. A reprodução: elementos para um teoria do sistema de ensino. Rio de Janeiro: Francisco Alves, 1975.

BRANCO, Maria Luísa. "O sentido da educação democrática : revisitando o conceito de experiência educativa em John Dewey". Educação e Pesquisa, São Paulo, maio/ago. 2010, v. 36 n. 2, p. $599-610$.

BRASIL. Secretaria de Educação Fundamental. Parâmetros Curriculares Nacionais: Arte. Brasília: MEC/SEF, 1997.

BRASIL. Ministério de Educação e do Desporto. Secretaria de Educação Fundamental. Referencial curricular nacional para a educação infantil. vol. 3. Brasília: MEC/SEF, 1998.

BRASIL. Ministério da Educação. Base Nacional Comum Curricular. Brasília: MEC, 2018.

BREHONY, Kevin J. "A new education for a new era: the contribution of the conferences of the New Education Fellowship to the disciplinary field of education 1921 - 1938". Paedagogica Historica, 2004, 40: 5-6, p. 733 - 755. 
BRITO, Maria T. A. Música na Educação Infantil. São Paulo: Peirópolis, 2003.

BRITO, Maria Teresa A. Por uma educação musical do pensamento: novas estratégias de comunicação. Tese (doutorado). Comunicação e semiótica. Pontifícia Universidade Católica de São Paulo. São Paulo, SP, 2007.

BROGAN, Whit. "Music : Report". Progressive Education, 1937, vol. XIV, p. 643.

CADY, Calvin B. "Functions of the creative principle in education". In : HARTMAN, Gertrude; SHUMAKER, Ann (org.). Creative expression: the development of children in Art, Music, Literature and Dramatics. New York: The John Day Company, 1932, p. 132 - 137.

CALDEIRA FILHO, J. C. Música criadora e balladas de Chopin. $1^{\mathrm{a}}$ ed. 1935, $2^{\mathrm{a}}$ ed., n.d.

CALDEIRA FILHO, João. "Educação musical infantil". Revista Brasileira de Estudos Pedagógicos, vol. III, n. 7, p. 120 - 122, 1945.

CAMBI, Franco. História da Pedagogia. Trad: Álvaro Lorencini. São Paulo: Fundação da Editora da UNESP, 1999.

CANCLINI, Néstor G. Culturas híbridas: estratégias para entrar e sair da modernidade. São Paulo: Editora da Universidade de São Paulo, 2015.

CATANI, Denice B. "A imprensa periódica educacional: as revistas de ensino e o estudo do campo educacional". Educação e Filosofia, 10 (20), p.115 - 130, jul./dez/ 1996.

CENTRAL sound systems. Progressive Education, 1940, vol. XVII, p. 381.

CHARTIER, Roger. A história cultural: entre práticas e representações. Trad. Maria Manuela Galhardo. Rio de Janeiro: Bertrand, 1990.

CHAPUIS, Elisabeth. "Les premières recherches en psychologie de l'enfant". In : FIJALKOW, Claire (org.). Maurice Chevais (1880 - 1943): Un grand pédagogue de la musique. Paris : L'Harmattan, 2004, p. 57 - 67.

CHEVAIS, Maurice. "L'Enseignement Musical en Allemagne”. La Nouvelle Éducation, abril 1930, n. 84, p. 53 - 58.

CHEVAIS, Maurice. "Le travail Musical Libre". La Nouvelle Éducation, jul. 1932, n. 107, p. $132-139$.

CHIARA, Frederico de. "Um livro orientador". CALDEIRA FILHO, J. C. Música criadora e balladas de Chopin. $2^{\mathrm{a}}$ ed., n.d., p. $15-16$.

CHOISY, Frank. "L'art et l'enfant". In THE NEW ERA. The creative self-expression of the child: a report of lectures. Londres : New Education Fellowship, 1921, p. $151-167$. 
CHRISTIANSON, Hellen. "Songs from many lands" (resenha). Progressive Education, 1937, vol. XIV, p. $667-668$.

COLEMAN, Satis N. Creative music for children. New York: Putnam, 1922.

COLEMAN, Satis N. A children's symphony: as developed in the Creative Music Classes of Lincoln School of Teachers College, with the themes composed entirely by the children, and played by them on instruments of their own making and other simple instruments. New York: Lincoln School of Teachers College, Columbia University, 1931a.

COLEMAN, Satis. "Creative Music" Progressive Education, 1931b, vol. VIII, p. 333 $-334$.

COLEMAN, Satis. "Creative experience through making musical instruments" In HARTMAN, Gertrude; SHUMAKER, Ann (org.). Creative expression: the development of children in Art, Music, Literature and Dramatics. New York: The John Day Company, 1932, p. $91-98$.

COLEMAN, Satis N. "The progress of the movement for Creative Music". Progressive Education, New York, vol. X, dec. 1932/ jan. 1933, p. 27 -31.

COLEMAN, Satis N. Your child's music. New York: John Day Company, 1939.

COLEMAN, Satis N. "La Musique Créatrice". La Nouvelle Éducation, n. 101, jan. 1932 , p. $13-15$.

COLEMAN, Satis N. "Fabriquons nos instruments de musique". La Nouvelle Éducation, n. 126, jun. 1934, p. 103 - 106.

COLLINS Jr., Fletcher. "Cultural resources in Rural America". Progressive Education, 1938, vol. XV, p.147 - 151.

COLLINS Jr., Fletcher. "The songs of the people". Progressive Education, 1942, vol. XIX, p. $12-14$.

COLUMBIA UNIVERSITY. The Lincoln School of Teachers College: a descriptive booklet. New York: The Lincoln School of Teachers College, 1922.

CONCERTS de Pipeaux. La Nouvelle Éducation, mar. 1935, n. 133, p. 44 - 46.

CONDETTE, Jean-François; SAVOYE, Antoine. "Une éducation pour une ère nouvelle : le congrès international d'éducation de Calais (1921)". Les Études Sociales, 2016/1 (n. 163), p. $43-77$.

CORSARO, William. "Peer culture". In: QVORTRUP, J.; CORSARO, W.; HONIG, M-S. The Palgrave Handbook of Childhood Studies. London: Palgrave, 2009, p. $301-315$. 
CORVISIER, Fátima M. "A trajetória musical de Antônio Leal de Sá Pereira". Revista do Conservatório de Música da UFPel, Pelotas, n.4, 2011, p. 162 193.

COSTA, Fabiola C. B. "A contribuição do Movimento Escolinhas de Arte no ensino de arte em Santa Catarina". Revista Nupeart. Florianópolis, SC, v. 8, n. 8, p. $11-27$, set. 2010 .

COUSINET, Roger. “L'Art des Enfants”. Pour l'Ère Nouvelle, vol. 1, n. 3, jul. 1922, p. $53-55$.

COUSINET, Roger. L'Éducation Nouvelle. 3ème éd. Neuchâtel: Delachaux et Niestlé, 1968.

CUNHA, Sandra M. "Onde estão as crianças? A invisibilidade da infância nas aulas de música na Educação Infantil". Anais [recurso eletrônico] $8^{\circ}$ Encontro de Pesquisa e Extensão do Grupo Música e Educação - MuSE: O ensino de música na educação básica. Florianópolis, UDESC, CEART, 2018, p. 36 - 46.

DAVIS, Katherine K. "Experiments in melody making”. In HARTMAN, Gertrude; SHUMAKER, Ann (org.). Creative expression: the development of children in Art, Music, Literature and Dramatics. New York: The John Day Company, 1932 , p. $75-80$.

DELALANDE, François. La música es un juego de niños. Trad.: Susana G. Artal. Buenos Aires: Ricordi, 1995.

DELALANDE, François. "L'educazione musicali da 0 a 6 anni". Bambini, Torino, janeiro de $\quad 1988 . \quad$ Disponível em http://www.comune.torino.it/centromultimediale/bambini/bambini_88.htm . Acesso em: 31 mar. 2019.

DELALANDE, François; FRAPAT, Monique. 'L'analyse Musicale à cinq ans : point de vue sur l'émission “L'oreille en Colimaçon"”. Analyse Musicale, n ${ }^{\circ} 5$ (4ème trimestre), Paris. 1986, p. 28 - 30.

DIXON, Madeleine. "What price convention?". Progressive Education, 1938, vol. XV, p. $485-488$.

DOSSE, François. La marche des idées: Histoire des intellectuels, histoire intellectuelle. Paris: Éditions La Découverte, 2003.

DUSHKIN, David. "Some experiments in music: the Glencoe Public Schools". Progressive Education, 1931, vol. VIII, p. 346 - 348

DUSHKIN, David. "An experiment in music education". Progressive Education, 1933, vol. XX, p. $144-149$.

DYKEMA, Peter W. "The place of the festival in modern life". In HARTMAN, Gertrude; SHUMAKER, Ann (org.). Creative expression: the development of 
children in Art, Music, Literature and Dramatics. New York: The John Day Company, 1932, p. $108-110$.

EDITORIAL. Revista Brasileira de Estudos Pedagógicos, vol. I, n.1, 1944, p. 5 - 6.

ELSBREE, Willard S. “A educação primária nos Estados Unidos”. Revista Brasileira de Estudos Pedagógicos, vol. XI, n.30, p. 249 - 282, 1947.

FELLOWS, Alice. "Creative Music and the bad boy". Progressive Education, 1931, vol. VIII, p. $348-349$.

FERRAZ, Maria Heloisa C. T.; FUSARI, Maria F. R. Metodologia do Ensino de Arte: fundamentos e proposições. $2^{\mathrm{a}}$ Ed. São Paulo: Cortez, 2009.

FERRIÈRE, Adolphe. "L'École Active". In : THE NEW ERA. The creative selfexpression of the child: a report of lectures. Londres: New Education Fellowship, 1921, p. $94-105$.

FERRIÈRE, Adolphe. Trois pionniers de l'Éducation Nouvelle. Ernest Flammarion: Paris, 1928.

FIJALKOW, Claire (org.). Maurice Chevais (1880 - 1943) : Un grand pédagogue de la musique. Paris : L’Harmattan, 2004.

FILHO, João Caldeira. "Educação musical infantil". Revista Brasileira de Estudos Pedagógicos, 1945, vol. III, n.7, p. $120-122$.

FONTERRADA, Marisa T. O. "Os Parâmetros Curriculares Nacionais e a Área de Música". In: CONGRESSO NACIONAL DA FEDERAÇÃO DOS ARTEEDUCADORES DO BRASIL, 11., 1998, Brasília/DF. Arte - políticas educacionais e culturais no limiar do século XXI. Anais... Brasília: 1998. p. 15 $-27$.

FONTERRADA, Marisa O. T. De tramas e fios: um ensaio sobre música e educação. São Paulo: Editora UNESP, 2008.

FONTERRADA, Marisa T. Ciranda de Sons: práticas criativas em educação musical. São Paulo: Editora Unesp Digital, 2015.

FREINET, Célestin. O texto livre. $2^{\text {a }}$ Ed. Trad: Ana Barbosa. Lisboa: Dinalivro, 1976.

GADOTTI, Moacir. História das ideias pedagógicas. $8^{\mathrm{a}}$ Ed. São Paulo: Ed. Ática, 2010

GAINZA, Violeta H. La improvisación musical. Buenos Aires: Ricordi, 2009.

GODET, Mireille. “L'Enfance Heureuse”. La Nouvelle Éducation, nov. 1925, n. 39, p. $132-134$. 
GODET, Mireille. “Au foyer de l'Enfance Heureuse”. La Nouvelle Éducation, n. 44, abril 1926, p. $55-56$.

GOLOMBEK, Patrícia. Caetano de Campos: A escola que mudou o Brasil. São Paulo: EDUSP, 2016.

GOODRICH, Helen. "The creative aspect of a may day festival". In HARTMAN, Gertrude; SHUMAKER, Ann (org.). Creative expression: the development of children in Art, Music, Literature and Dramatics. New York: The John Day Company, 1932, p. $111-115$.

GRAETZER, G.; YEPES, A. Guía para la práctica de "Música para niños" de Carl Orff. Buenos Aires: Ricordi, 1983.

GUÉRITTE, Madeleine. "La Musique et les Enfants". La Nouvelle Éducation, dez. 1924, n. 30, p. $146-148$.

GUÉRITTE, Madeleine. "Notre classe expérimentale de Sedan". La Nouvelle Éducation, n. 41, jan. 1926, p. 6 - 7.

GUÉRITTE, Madeleine. "Anthologie du chant scolaire". La Nouvelle Éducation, n. 48 , out. 1926 , p. $157-158$.

GUÉRITTE, Madeleine. "Les jeux dramatiques et la Musique". La Nouvelle Éducation, n. 55, maio 1927, p. $76-78$.

GUÉRITTE, Madeleine. "Pour une méilleure éducation musicale". La Nouvelle Éducation, jan. 1936, n. 141, p. $10-12$.

GUÉRITTE, Madeleine. "La grande pitié de la Musique en France". La Nouvelle Éducation, n. 155 , maio 1937 , p. $70-74$.

GUÉRITTE, Madeleine. “La Musique d'amateurs”. La Nouvelle Éducation, maio 1938 , n. 165 , p. $73-78$.

GUÉRITTE, Madeleine. "Enquête sur l'état de la Musique dans nos Provinces". La Nouvelle Éducation, mar. 1939, n. 173, p. 39 - 43.

GUÉRITTE, Madeleine. "Enquête sur l'état de la Musique dans nos Provinces (suite)". La Nouvelle Éducation, abr. 1939, n. 174, p. 58 - 59.

GUILDE française des Faiseurs et Joueurs de Pipeaux. La Nouvelle Éducation, out. 1933, n. 118 , p. $149-150$.

GUTIERREZ, Laurent. 'L'Oiseau Bleu: histoire d'une revue rédigée par des enfant pour des enfant (1922 - 1929)" Le Télémaque, n.32 - L'Enfant et l'imaginaire, nov. 2007, p. $111-124$.

GUTIERREZ, Laurent. "Roger Cousinet : un disciple d'Alfred Binet en pédagogie". Bulletin de Psychologie, tome 64 (3), 513, maio - jun. 2011, p. 227 - 232. 
GUTIERREZ, Laurent; SAVOYE, Antoine. "Sauver les jeunes générations de la faillite éducative : le combat de Madeleine Guéritte". In RIONDET, X.; HOFSTETTER, R.; GO, H. L. Les acteurs de l'Éducation nouvelle au XXe siècle : Itinéraires et connexions. Grenoble : PUG, 2018.

GUTIERREZ, L.; BESSE, L.; PROST, A. "Introduction" In: GUTIERREZ, L.; BESSE, L.; PROST, A (Dir). Réfomer lécole - L'apport de l'Éducation Nouvelle (1930 - 1970). Grenoble: PUG, 2012.

GVIRTZ, Silvina; CORIA, Julia. “Alcances y límites de la investigación en la historia de la educación comparada". História da Educação, Pelotas, n.10, p. 17-29, out. 2001.

HAMELINE, Daniel. "L'Institut Jean Jacques Rousseau et L'Éducation Nouvelle". In OHAYON, A.; OTTAVI, D. SAVOYE, A (Ed). L'Éducation Nouvelle: histoire, présence et devenir. Berne: Peter Lang, 2004a, p. 145 - 162.

HAMELINE, Daniel. "Preface". In FERRIÈRE, Adolphe. L'École Active. Paris : Éditions Fabert, 2004b.

HAENGGELI-JENI, Béatrice; HOFSTETTER, Rita. "Pour l'Ère Nouvelle (1922 1940): La science convonquée pour fonder une "internationale de l'éducation"'. In GUTIERREZ, Laurent. Carrefours de l'Éducation, n. 31, jan. - jun. 2011. Dossiê "Histoire du mouvement de l'éducation nouvelle".

HAENGGELI-JENI, Béatrice. 'L'Éducation Nouvelle: débats autour de définitions conceptuelles et identitaires (1922 - 1940). In GUTIERREZ, L.; BESSE, L.; PROST, A. Réfomer lécole - L'apport de l'Éducation Nouvelle (1930-1970). Grenoble: PUG, 2012.

ILLICH, Ivan. Sociedade sem escolas. Petrópolis: Vozes, 1973.

INSTRUMENTS de musique fait par les enfants. La Nouvelle Éducation, jul. 1932, n. 107, p. $140-141$

JACQUET-FRANCILLON, François. "L'enfant comme personne : Un fondement culturelle de l'Éducation Nouvelle". In OHAYON, Annick; OTTAVI, Dominique e SAVOYE, Antoine (dir.), L'Education nouvelle. Histoire, présence, devenir, Berne, Peter Lang, 2004, p. 29 - 45.

JACQUET-FRANCILLON, François. "Epilogue”, p. 395 - 401. In GUTIERREZ, L.; BESSE, L.; PROST, A. Réfomer lécole - L'apport de l'Éducation Nouvelle (1930 - 1970). Grenoble: PUG, 2012.

JAMES, Margaret. "Nous fabriquons nos pipeaux". La Nouvelle Éducation, mar. 1933, n. 113, p. $41-44$

JENKINS, Celia. "New Education and its emancipatory interests (1920-1950)". History of Education, 2000, vol. 29, n. 2, p. 139-151. 
KEEP, Susan. "Music for all of us" (resenha). Progressive Education, 1944, vol. XXI, p. 115 , p. 149.

KRAMER, Max. "An experiment in indian education.” Progressive Education, 1935, vol. XII, p. $155-159$.

LAWLER, Valnett. "A educação musical em 14 repúblicas americanas". Revista Brasileira de Estudos Pedagógicos, vol. VII, n.19, p. 34 - 55, 1946.

L'ÉDUCATION nouvelle aux États-Unis. La Nouvelle Éducation, nov. 1924, n. 29, p. $133-135$.

LEIS Orgânicas do Ensino Primário e do Ensino Normal. Revista Brasileira de Estudos Pedagógicos, vol. VII, n. 20, fev. 1946, p. 260 - 287.

LE VI ${ }^{\mathrm{e}}$ Congrès de la Ligue Internationale d'Éducation Nouvelle. La Nouvelle Éducation, out. 1932, n. 108 , p. $156-158$.

LES GUILDES des Faiseurs de Pipeaux. La Nouvelle Éducation, nov. 1937, n. 159, p. $143-146$.

LES GUILDES des Faiseurs de Pipeaux. La Nouvelle Éducation, n. 163, mar. 1938, p. $42-45$.

LÉVI-STRAUSS, Claude. Race and history. Paris: Unesco, 1952.

LOURENÇO FILHO, Manoel B. Introdução ao Estudo da Escola Nova. Companhia Melhoramentos: São Paulo, 1929.

LOURENÇO FILHO, Manoel B. Educação Comparada. $3^{\text {a }}$ ed. Brasília: MEC/ Inep, 2004.

LUCENA, C., LUCENA, L. "Prefácio". In: DEWEY, John. Impressões sobre a Rússia Soviética e o Mundo Revolucionário. Trad: Carlos Lucena. Uberlândia: Navegando, 2016. p. $7-26$.

L'UTILISATION des Loisirs. La Nouvelle Éducation, n. 153, mar. 1937, p. 33 - 34.

MONARCHA, Carlos. Brasil arcaico, escola nova: ciência, técnica e utopia nos anos 1920-1930. São Paulo: Ed. UNESP, 2009.

MOREIRA, Tamya de O. R. A música na Pedagogia Freinet: diálogos com a educação musical do século XX. Dissertação (Mestrado em Artes). São Paulo: ECA/ USP, 2014.

MUSIC in the new school. Progressive Education, 1939, vol. XVI, p. 212.

MUSIQUE pour Enfants. La Nouvelle Éducation, n. 102, fev. 1932, p. 29 - 30. 
NEWMAN, Elizabeth. "A rational approach to music teaching". In : HARTMAN, Gertrude; SHUMAKER, Ann (org.). Creative expression: the development of children in Art, Music, Literature and Dramatics. New York: The John Day Company, 1932, p. $86-90$.

NEWLON, Jesse H. "Introduction". In COLEMAN, Satis N. A children's symphony: as developed in the Creative Music Classes of Lincoln School of Teachers College, with the themes composed entirely by the children, and played by them on instruments of their own making and other simple instruments. New York: Lincoln School of Teachers College, Columbia University, 1931, p. v vi.

NOS Cercles d'études. La Nouvelle Éducation, n. 154, abr. 1937, p. 60 - 62.

NOTRE Nouvelle Année. La Nouvelle Éducation, jan. 1924, n. 21, p. 1 - 2.

NOTRE III ${ }^{\mathrm{e}}$ Assemblée. La Nouvelle Éducation, jun. 1924, n. 26, p. 53 - 54.

NOTRE IV ${ }^{\mathrm{e}}$ Assemblée. La Nouvelle Éducation, jun. 1925, n. 36, p. 61 - 62.

NOUVELLES. La Nouvelle Éducation, maio 1925, n. 116, p. 78 - 80.

NOUVELLES. La Nouvelle Éducation, mar. 1926, n. 44, p. 61 - 62.

NOVOA, Antonio. 'Modèles d'analyse en éducation comparée : le champ et la carte'. Education comparée. Montreal/ Paris : L’Harmattan, 1998, p. 9 - 61.

NUSSBAUM, Robert. "L'Enfant est-il capable de puissance créatrice ?” In : THE NEW ERA. The creative self-expression of the child: a report of lectures. Londres : New Education Fellowship, 1921, p. 45 - 62.

OELKERS, Jürgen. "Origin and Development in Central Europe". In RÖHRS, H. ; LENHART, V. (eds.) Progressive Education across the continents. Frankfurt : Peter Lang, 1995.

OHAYON, A.; OTTAVI, D. SAVOYE, A (Ed). L'Éducation Nouvelle: histoire, présence et devenir. Berne: Peter Lang, 2004.

PALM, Reuben R. The origins of Progressive Education. The Elementary School Journal, vol. 40, n. 6, 1940, p. $442-449$.

PAZ, Ermelinda A. Pedagogia Musical Brasileira no século XX: metodologias e tendências. $2^{\text {a }}$ ed. Brasília: Editora MusiMed, 2013.

PENNA, Maura. "Música na Escola: analisando a proposta dos PCN para o Ensino Fundamental". PENNA, Maura (Coord.). É este o ensino de Arte que queremos? Uma análise das propostas dos Parâmetros Curriculares Nacionais. João Pessoa: Editora Universitária, 2001.

PENSÉE. La Nouvelle Éducation, jan. 1928, n. 61, p. 15. 
PERHAM, Beatrice. "An environment for music". Progressive Education, 1935, vol. XII, p. $409-412$.

PIERCE, Anne E. "Review of "A children's symphony". The Elementary School Journal, jun. 1932, vol. 32 (10), p. 788.

PISTONE, Danièle. "Vie musicale et pedagogie dans le Paris de l'entre-deuxguerres". In: FIJALKOW, Claire (org.). Maurice Chevais (1880 - 1943) : Un grand pédagogue de la musique. Paris : L'Harmattan, 2004, p. 13- 26.

POND, Donald. "Music as a social function in the child's world". Progressive Education, 1936, vol. XIII, p. $174-178$.

PORTARIA ministerial n.215, de 18 de abril de 1945. Revista Brasileira de Estudos Pedagógicos, vol. IV, n. 12, jun. 1945, p. $462-463$.

PORTARIA $\mathrm{n}^{\mathrm{o}} 300$ de 07 de maio de 1946. Revista Brasileira de Estudos Pedagógicos, vol. VIII, n. 22, p. $195-198$.

PORTARIA n.586 de 3 de dezembro de 1945. Revista Brasileira de Estudos Pedagógicos, vol. VII, n. 19, p. $167-168$.

POTTER, Edith. "Values in the use of instruments in school projects". Progressive Education, 1931, vol. VIII, p. $345-346$

POTTER, Edith. “A children's symphony” (resenha). Progressive Education, 1932, vol. IX, p. 527.

POTTER, Edith. "The development of musical consciousness in the young child". In HARTMAN, Gertrude; SHUMAKER, Ann (org.). Creative expression: the development of children in Art, Music, Literature and Dramatics. New York: The John Day Company, 1932, p. 116 - 124.

PRATIER, J. M. “L'enfant poète et musicien”. La Música à l'école, jan. 1927, n. 4, p. $64-65$.

RAILLON, Louis. "L'Éducation Nouvelle a-t-elle existé ?" In OHAYON, A. ; OTTAVI, D. ; SAVOYE, A. (Ed.) L'Éducation Nouvelle : histoire, présence et devenir. Peter Lang : Berne, 2004, p. p. 317 - 326.

RAILLON, Louis. Demolins (Edmond). "À quoi tient la supériorité des AngloSaxons?" [resenha]. Revue Française de Pédagogie, n.132, juillet - août septembre, 2000, p.160- 164 .

RAPPORT de notre $V^{\mathrm{e}}$ Assemblée. La Nouvelle Éducation, jun. 1926, n. 46, p. 81 82.

RAPPORT de notre VI ${ }^{\mathrm{e}}$ Assemblée. La Nouvelle Éducation, jun. 1927, n. 56, p. 81 83. 
RAPPORT de notre VII ${ }^{\mathrm{e}}$ Assemblée. La Nouvelle Éducation, jun. 1928, n. 66, p. 81 85.

RAPPORT de notre VIII ${ }^{\mathrm{e}}$ Assemblée. La Nouvelle Éducation, jun. 1929, n. 76, p. 81 -84 .

RAPPORT de notre IX ${ }^{\mathrm{e}}$ Assemblée. La Nouvelle Éducation, jun. 1930, n. 86, p. 81 83.

RAPPORT de notre $X^{\mathrm{e}}$ Assemblée. La Nouvelle Éducation, jun. 1931, n. 96, p. 81 82.

RAPPORT de notre $\mathrm{XI}^{\mathrm{e}}$ Assemblée. La Nouvelle Éducation, jun. 1932, n. 106, p. 81 -83 .

RAPPORT de notre XII ${ }^{\mathrm{e}}$ Assemblée. La Nouvelle Éducation, jun. 1933, n. 116, p. 81 -83 .

RAPPORT de notre XIII ${ }^{\mathrm{e}}$ Assemblée. La Nouvelle Éducation, jun. 1934, n. 126, p. $81-84$.

RAPPORT de notre XIV ${ }^{\mathrm{e}}$ Assemblée. La Nouvelle Éducation, jun. 1935, n. 136, p. $81-84$

RAPPORT de notre XV $\mathrm{XV}^{\mathrm{e}}$ Assemblée. La Nouvelle Éducation, jun. 1936, n. 146, p. 81 -85 .

RAPPORT de notre XVI ${ }^{\mathrm{e}}$ Assemblée. La Nouvelle Éducation, jun. 1937, n. 156, p. $81-85$.

RAPPORT de notre XVII ${ }^{\mathrm{e}}$ Assemblée. La Nouvelle Éducation, jun. 1938, n. 166, p. $81-85$.

RAPPORT de notre XVIII ${ }^{\mathrm{e}}$ Assemblée. La Nouvelle Éducation, jun. 1939, n. 176, p. $81-86$.

ROCHA, Inês de A. Canções de Amigo: redes de socialbilidade na correspondência de Liddy Chiaffarelli Mignone para Mário de Andrade. Rio de Janeiro: Faperj, 2012a.

ROCHA, Inês de A. “"QQuanta coisa para pensar nos tem dado essa gente”: educadores musicais brasileiros em viagem aos Estados Unidos. Opus, Porto Alegre, vol. 18, n.1, p. 101 - 126, jun. 2012 b.

ROCHA, Inês de A. "Modernidade e Modernismo na Iniciação Musical e nas práticas educativas de Liddy Chiaffarelli Mignone" Revista da ABEM, Londrina, v. 25, n. 39 , jul. - dez. 2017, p. $20-38$. 
RÖHRS, Hermann. "The New Education Fellowship : An international forum for Progressive Education". In RÖHRS, H. ; LENHART, V. (eds.) Progressive Education across the continents. Frankfurt : Peter Lang, 1995, p. $179-191$.

ROSENTRAUCH, Henrietta. "Music education of tomorrow". Progressive Education, 1944, vol. XXI, p. 131 - 134.

ROTH, Lina. “Le Pipeau et le Chant”. La Musique à l'École. n. 194, jan. 1937, p. 61 $-62$.

ROTHEN, José C. "O Instituto Nacional de Estudos Pedagógicos: uma leitura da RBEP”. Revista Brasileira de Estudos Pedagógicos, Brasília, v. 86, n. 212, p.189 - 224, jan./abr. 2005.

SÁ PEREIRA, Antônio. Psicotécnica do Ensino Elementar da Música. São Paulo: José Olympio, 1937.

SÁ PEREIRA, Antônio. Mobilização musical da juventude americana (impressões de viagem). Rio de Janeiro: Escola Nacional de Música da Universidade do Brasil, Ministério da Educação e Saúde, 1942.

SARAMAGO, José. O evangelho segundo Jesus Cristo. São Paulo: Companhia das Letras, 1991.

SARMENTO, Manuel Jacinto. "As crianças e a infância: definindo conceitos, delimitando o campo". In: PINTO, M; SARMENTO, M. As crianças: contextos e identidades. Braga: Centro de Estudos da Criança/ Universidade do Minho, 1997, p. 9 - 30.

SARMENTO, Manuel Jacinto. "Visibilidade social e estudo da infância". In: VASCONCELOS, V. M. R.; SARMENTO, M. J. (org.). Infância (in)visível. Araraquara: Junqueira \& Marin, 2007, pp. 25-49.

SAVIANI, Dermeval. Escola e democracia. Campinas: Autores Associados, 2008.

SAVIANI, Dermeval. História das ideias pedagógicas no Brasil. $4^{\mathrm{a}}$ ed. Campinas: Autores Associados, 2013.

SAVOYE, Antoine. "L'Éducation Nouvelle en France, de son irrésistible ascension à son impossible pérennisation (1944 - 1970)". OHAYON, A.; OTTAVI, D. SAVOYE, A (Ed). L'Éducation Nouvelle: histoire, présence et devenir. Berne: Peter Lang, 2004, p. 235 - 269.

SEYMOUR, Harriet A. "Creative expression in music". In In HARTMAN, Gertrude; SHUMAKER, Ann (org.). Creative expression: the development of children in Art, Music, Literature and Dramatics. New York: The John Day Company, 1932 , p. $81-85$.

SHEVOCK, Daniel J. "Satis Coleman - A spiritual philosophy for Music Education". Music Educator Journal, 2015, vol. 102 (1), p. 56 - 61. 
SHUMAKER, Ann. "Foreword". In HARTMAN, Gertrude; SHUMAKER, Ann (org.). Creative expression: the development of children in Art, Music, Literature and Dramatics. New York: The John Day Company, 1932, p. 5.

SIGAUX-RAVEL. "Essai d'initiation musicale". La Nouvelle Éducation, fev. 1928, n. 62 , p. $24-28$

SOUTHCOTT, Jane. "A music education pioneer - Satis Naronna Barton Coleman" British Journal of Music Education, jul. 1990, vol. 7 (2), p. 123 - 132.

SOUTHCOTT, Jane. "The seeking attitude : Ideas that inluenced Satis Coleman". Journal of Historical Research in Music Education, 2009, vol. 31 (1), p. 20 36 .

SPESSARD, Katharine H. "Appreciating China in America". Progressive Education, 1935, vol. XII, p. $202-205$.

STEELE, Ellen. W. ; LILLARD, Rosemary. "Creative music in the group life". In: HARTMAN, Gertrude; SHUMAKER, Ann (org.). Creative expression: the development of children in Art, Music, Literature and Dramatics. New York: The John Day Company, 1932, p. 125 - 131.

STOKOWSKI, Leopold. "Fading out of musical creation". Progressive Education, 1937, vol. XIV, p. 245.

STOKOWSKI, Leopold. Music for all of us. New York: Simon and Schuster, 1943.

SURETTE, Thomas Whitney. "Music teaching in schools". Progressive Education, 1930, vol. VII (3), p. $107-114$.

SURETTE, Thomas Whitney. "A general view of music education for children". In HARTMAN, Gertrude; SHUMAKER, Ann (org.). Creative expression: the development of children in Art, Music, Literature and Dramatics. New York: The John Day Company, 1932, p. 69 - 74.

THE NEW ERA. The creative self-expression of the child: a report of lectures. Londres : New Education Fellowship, 1921.

UNESCO. United Nations. Educational, Scientific and Cultural Organization. Education for people and planet: Creating sustainable futures for all. Global Education Monitoring Report. Paris, 2016.

VANÇON, Jean-Claire. "De la polémique gauliniste (1882-1883) au conflit Chevais/ Gedalge (1917 - 1923): l'histoire de la musique à l'école à la Lumière de ses quereles pédagogiques". In: FIJALKOW, Claire (org.). Maurice Chevais (1880 - 1943) : Un grand pédagogue de la musique. Paris: L'Harmattan, 2004, p. 39 - 56. 
VENÂNCIO FILHO, Francisco. Notas de Educação. Rio de Janeiro, RJ: Calvino, 1933.

VIDAL, D. G. Múltiplas estratégias de escolarização da infância. In: Congresso Brasileiro de História da Educação, 3, 2004, Curitiba. Anais.... Curitiba: 2004. Disponível http://sbhe.org.br/novo/congressos/cbhe3/Documentos/Coord/Eixo4/491.pdf Acesso em 26 de abr. de 2019.

VILLA-LOBOS, Heitor. "Portaria $\mathrm{n}^{\circ} 1$, de 5 de janeiro de 1946, do diretor do Conservatório Nacional de Canto Orfeônico". Revista Brasileira de Estudos Pedagógicos, vol. VII, n. 20, fev. 1946, p. $408-410$.

VOLK, Terese M. “Satis Coleman's Creative Music”. Music Educators Journal, maio 1996, vol. 82 (6), p. $31-33$.

WALLACE, James M. "The origin and development of Progressive Education in the United States of America: New World Progressives in th Old World". In RÖHRS, H.; LENHART, V. (eds.) Progressive Education across the continents. Frankfurt : Peter Lang, 1995.

WHITING, Helen A. "Negro children study race culture". Progressive Education, 1935, vol. XII, p. $172-180$.

WILLEMS, Edgar. El valor humano de la educación musical. Barcelona: Paidós, 2002.

ZILVERSMIT, Arthur. Changing Schools: Progressive Education Theory and Practice, 1930 - 1960. Chicago: The University of Chicago Press, 1993. 